\title{
TEACHING GEOMETRY \\ USING COMPUTER VISUALIZATION
}

Ph.D. dissertation

Elvira Ripco Sipos

Supervisor:

József Kosztolányi

Doctoral School in Mathematics and Computer Science Bolyai Institute

University of Szeged, 2011. 


\section{Acknowledgment}

I would like to express my gratitude to everybody who helped me in some way in the elaboration of my dissertation.

Special thanks to my supervisor, Dr. József Kosztolányi, professor at the Bolyai Institute, University of Szeged whose useful suggestions and ideas helped me in completing this work. I thank him ever wholeheartedly for his help and for the great moral support.

I would like to thank professor Dr. János Karsai for leading me to wonders of Mathematica software and for making the IPA-Project stylesheet available to me (HU-SRB/0901/221/088 TEAMATHMODSCI).

I am also thankful to professors Dr. Djurdjica Takači and Dr. Árpád Takácsi from the University of Novi Sad for their help and useful suggestions regarding my work.

I also owe special thanks to my family for encouraging and supporting me during the completion of this work.

It is by logic that we prove, but by intuition that we discover. 


\section{Contents}

1. Introduction 2

2. Teaching and learning mathematical concepts and mathematical cre$\begin{array}{ll}\text { ativity } & 10\end{array}$

3. Geometry I , Planimetry 14

3.1. The task . . . . . . . . . . . . . . . . . . . 14

3.2. Visualization on the computer . . . . . . . . . . . . . . 15

3.3. Comprehensive tasks for assessment and evaluation . . . . . . . . . . . 19

3.4. Revision after the winter holiday . . . . . . . . . . . . . . 22

3.5. Results of Geometry I . . . . . . . . . . . . . . . . . . 25

3.5.1. The tasks on the second exam . . . . . . . . . . . . 25

3.5.2. The results of the second exam . . . . . . . . . . . . . . 32

3.5.3. The results at the end of the school year . . . . . . . . . . . . 34

3.6. Summary . . . . . . . . . . . . . . . . . . . 34

4. Geometry II, Trigonometry 36

4.1. Menelaus' theorem . . . . . . . . . . . . . . . . . 36

4.2. Ceva's theorem . . . . . . . . . . . . . . . . . 43

4.3. Ptolemy's theorem . . . . . . . . . . . . . . . . . . 46

5. Geometry III, Linear algebra and analytical geometry 49

5.1. Euler's line . . . . . . . . . . . . . . . . . . . . . . . 49

5.2. General form of Euler's line . . . . . . . . . . . . . . . . 55

5.2.1. The equations of the lines $A B, B C$ and $A C \ldots \ldots . \ldots 5$

5.2.2. Altitudes and the orthocenter of the triangle . . . . . . . . . . 55

5.2.3. The medians and the barycenter . . . . . . . . . . . . . 56

5.2.4. The perpendicular bisectors and the circumcenter . . . . . . . . 57

5.2.5. The equation of the line $\mathrm{HO}$. . . . . . . . . . . . . . . 57

5.2.6. The coordinates of vectors HT and TO . . . . . . . . . . . . 58

5.3. Ceva's theorem . . . . . . . . . . . . . . . . 59

5.4. Menelaus' theorem . . . . . . . . . . . . . . . . . . 61

$\begin{array}{ll}\text { 6. Apollonius' problems } & 63\end{array}$

6.1. Apollonius of Perga . . . . . . . . . . . . . . . . . . 64

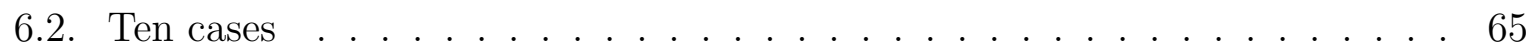

7. Is there geometry after Euclid? $\quad 82$

7.1. Hyperbolic geometry . . . . . . . . . . . . . . . . . . . . 83

7.2. Spherical geometry . . . . . . . . . . . . . . . . . 87

$\begin{array}{ll}\text { 8. Summary } & 93\end{array}$

9. Összefoglaló $\quad 98$

$\begin{array}{ll}\text { 10.Appendix } & 103\end{array}$

$\begin{array}{ll}\text { 11.Publications and Conferences } & 114\end{array}$ 


\section{Introduction}

Teaching mathematics in a secondary school is a very difficult task. Its most interesting area is axiomatically built geometry [21]. Helping students understand and learn new theorems in geometry is an exciting task from a teacher's point of view. Some psychological and didactical surveys show that the acquisition and learning of geometry in secondary school is a very difficult task. This could be due to a lack of problem-solving-thinking or to the decreasing creativity of the students. Consequently, few schoolchildren get to know the amazing world of the science of the Ancient Greek geometers'. The incompleteness and imperfection of representation on paper and the limited time available hinder students' learning of axiomatically-based theoretical geometry. A great number of geometrical figures, their symmetries, perfection and variety remain unknown for some students who have finished secondary school. One of the most important tools for children in the $21^{\text {st }}$ Century is their companion, the computer. Applying the computer in the teaching and learning processes plays an important role in education. The method of introduction of the computer during the course of teaching and learning is very important from the aspect of achievement of the cognitive processes. The appearance and rapid development of dynamic geometry systems (DGS) has brought rapid progress in the teaching of geometry.

\section{Research Aim}

My research aim is to map out in which proportions it is necessary and sufficient to apply dynamic geometry system and computer, since visualization on the computer is not the only teaching-device we have at our disposal to use during geometry lessons. Besides understanding the theorems, our students should find good proofs and it is necessary to practice the elementary geometrical constructions using a compass and rulers. It is important to find an optimal qualitative and quantitative balance during lessons of time spent on the visualization and theoretical proofing of constructions. The aim of the thesis was to follow the development of these students for three years of secondary school, because I think that concepts learned using different methods will give the expected results.

\section{Structure of the Thesis}

In the first three sections of the thesis the famous theorems of Euclidean geometry are examined at different aspects. These theorems are:

- Euler's line: For the given three points $A, B$ and $C$ the important points of the triangle $A B C$ orthocenter $(H)$, circumcenter $(O)$ and barycenter $(T)$ are collinear points, and

$$
\overrightarrow{H T}=2 \cdot \overrightarrow{T O}
$$

- Ceva's theorem: Given a triangle $A B C$, and points $D, E$ and $F$ that lie on lines 
$B C, C A$ and $A B$ respectively, than lines $A D, B E$ and $C F$ are concurrent if and only if

$$
\frac{A F}{F B} \cdot \frac{B D}{D C} \cdot \frac{C E}{E A}=1
$$

- Menelaus' theorem: Given points $A, B, C$ that form triangle $A B C$, and points $D$, $E, F$ that lie on lines $B C, A C, A B$, points $D, E, F$ are collinear if and only if

$$
\overline{\overline{F B}} \cdot \frac{\overline{B D}}{\overline{D C}} \cdot \frac{\overline{C E}}{\overline{E A}}=-1 \text {. }
$$

- Ptolemy's theorem: Let a convex quadrilateral $A B C D$ be inscribed in a circle, then the sum of the products of the two pairs of opposite sides equals the product of its two diagonals.

Using a computer in complicated calculations helps to reach the main purpose, aim: theorems had been proven synthetically by elementary methods of axiomatically built Euclidean geometry, then they were proven in trigonometry and after in general form by analytical geometry. The principle of spirality to deepen the students' geometrical knowledge is observable here.

The three steps of spirality are:
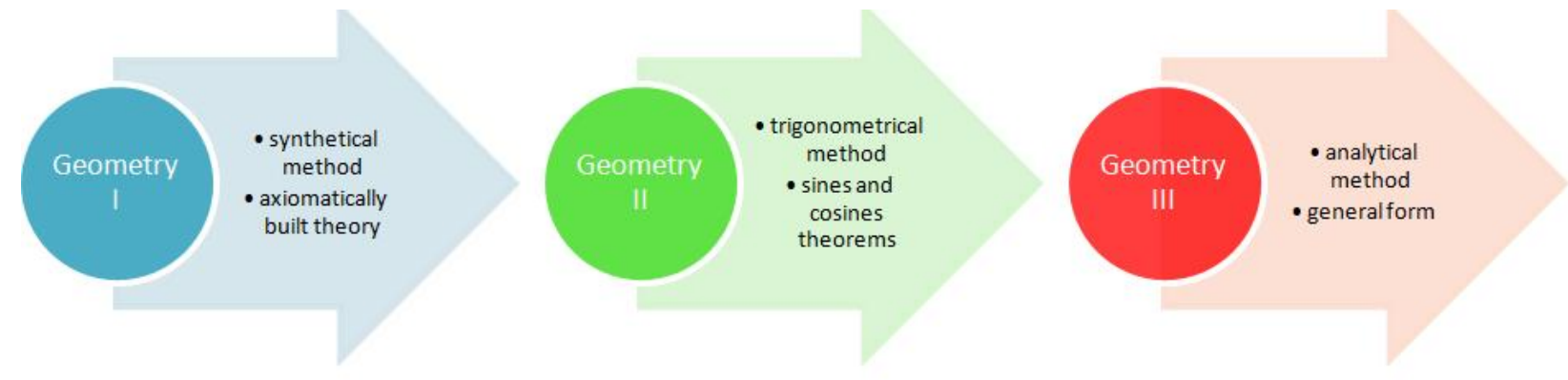

Every section has summarized the results of students' achievement and the development of their knowledge with tables of the number of points gained, and/or marks on the assessments.

The last two sections are about constructing inversion (as planar transformation) and about teaching and learning different axiomatically built geometrical theories. In the seventh section the ten cases of Apollonius' problems are shown (Given three objects, each of which may be a point, line, or circle, draw a circle that is tangent to each.), along with a student's classical construction on paper.

The eighth section is the presentation of the two great non-Euclidean theories in geometry, hyperbolic and spherical geometry.

Appendix 1 includes the Serbian Ministry of Education's plans for the teaching of Geometry. 
In Appendix 2 the works in DGS found on the attached CD are listed.

Appendix 3,4 and 5 are Mathematica-files in notebook form.

\section{Teaching Experiences}

I am a geometry teacher in the Bolyai Grammar School and Dormitory for Gifted Students in Senta, Serbia. This is a unique school in Serbia because the teaching language is Hungarian but the school is accredited as a special mathematical secondary school with programs given by the Ministry of Education of Serbia. It targets the talented students of the region, specializes in natural sciences and mathematics and offers Hungarian as the language of instruction. The school was founded under the name Secondary Grammar School Specialized in Natural Sciences and Mathematics for Gifted Students on April 22, 2003.

Besides Hungarian, the curriculum comprises of English (or German) language, Serbian language Biology, History, Geography, Physics, Chemistry and computer Science, and there are four mathematical subjects as well.

1. Algebra and Analysis in every grade (9-12) with 4 lessons per week;

2. Geometry in the first(9) and second (10) grades with 4 lessons per week

3. Linear algebra and analytical geometry in the third (11) grade with 3 lessons per week;

4. Probability and statistics in the fourth (12) grade with 2 lessons per week.

The graduates' final exam includes written exams from the Hungarian language, Analysis and Algebra, and the third subject is chosen freely from Geometry, Physics and Computer Science. The students in the Bolyai school have to pass an entrance exam, which is organized for the pupils in elementary school in the eighth grade (at 14 years old), in June of every year. This exam contains very difficult tasks from elementary school mathematics, but using higher level. That is why teachers of mathematical subjects of the school keep preparing lessons every winter and spring from January to May. While working with potential students of the school, teachers gain insight about their skills and can help to refill gaps in the methods of problem solving, in deepening the knowledge, helping to understand the definition of the concept. There are 20 places for students entering the first (9) grade; this is the Bolyai grammar school's limit. There are much more beginners at the first meeting, but at the end there are about 50-60 pupils who write the entering exam. The results of this exam are that now there are 20 students in the first grade, 22 in the second, 26 in the third and 19 in the fourth one. The first generation graduated last year, graduate exams gave excellent results, and average marks were 4.33 from Geometry, and 4.5 from Algebra and Analysis. All of them were admitted to the chosen universities in Serbia and Hungary and won scholarships for their studies.

My students have 144 geometry lessons per year and if it is possible, every lesson is in IT classroom; that is about 25 percent using DGS and some 75 percent of the lessons are "classical" geometry, using paper in "classical" constructions using pencil, rulers and compasses, because they have to develop their motor skills.

My method is as follow: every student has a desk and a computer; pictures of the main/teacher's computer are reflected on the whiteboard, so that the students can follow 
the instructions. They can recognize new aspects using DGS. They are able to find new methods of proving theorems; they gain a visual perception of the properties of the given problem by "moving" the basic points on the drawing. This kind of imaging is impossible in classical constructions in geometry, because it would entail drawing hundreds of accurate, precise constructions on paper. I expect the students to be able to visualize mathematical and geometrical problems and to achieve the problem-solving abilities at the end of the course. This teaching is unique in Serbia because the language of instruction is Hungarian, and we are able to teach our students according to the plans of the special mathematical grammar schools in Belgrade, Novi Sad, Kragujevac and Nis.

\section{Preliminary overview}

Considering that my students needed help in learning Geometry, and as I have read and studied some papers of eminent Hungarian and American researchers I have found that (as David Tall writes in his book [29]):

"Although the experts in mathematics may claim to share a coherent notion of proof, the cognitive development of proof is dependent on the cognitive structure and representations available to the learner at a given time. The formal concept of proof in terms of definition and logical deduction has a significant cognitive difficulty; it requires a reversal from concepts described verbally to verbal definitions which prescribe concepts.

This is likely to be highly confusing to non-experts."

In the study [30] he also writes:

"By using suitable visual interpretations of mathematics it may be possible to draw one or more pictures which in total are formally generative, in the sense that they may be interpreted appropriately by some students to lead to corresponding formal arguments. For some students (successful natural learners), the pictures may allow them to construct a personal meaning for the definitions which allows them to build a rich conceptual structure to support the formal mathematics. For others (successful formal learners), working by interiorizing the definitions and reflecting on the formal proofs may also lead to successful under- standing of theorems and proofs, although further cognitive reconstruction is likely to be needed if the student wishes to integrate these new formal ideas with older intuitions."

One of the most important tools for children in the $21^{\text {st }}$ Century is their companion, the computer. Children born after 2000 are called Digital Natives by Marc Prensky [18], while we, the others born in the $20^{\text {th }}$ Century are Digital Immigrants with methodical thinking. Our students today are all native speakers of the digital language of computers, video games and the Internet.

Applying the computer in the teaching and learning processes plays an important role. It is important how we introduce the computer during the course of teaching and learning from the aspect of the achievement of the cognitive processes. The appearance and rapid development of dynamic geometry systems(DGS) has brought rapid progress in the teaching of geometry.

The use of computers in teaching is based on some of David Tall's ideas [31]: 
"The introduction of computer technology brings a new refinement to this theory. Whereas model is seen as the individual acting on and experimenting with materials that are largely passive, a computer environment can be designed to re-act to the actions of the individual in a predictable way. This new form of interaction extends Skemp's theory to four modes (Tall 1989) where building and testing environments are:

- Inanimate: the stimuli come from real objects which the individual may also be able to manipulate,

- Cybernetic: the stimuli come from systems which are set up to react according to pre-ordained rules,

- Interpersonal: the stimuli come from other people,

- Personal: the stimuli are from the individual's own cognitive structure.

The new cybernetic mode of building and testing concepts accords rich possibilities for the learning of mathematics."

This is why I decided to institute computer-aided visualization in the teaching and learning of geometry in our school.

\section{Teaching method}

My method, teaching geometry using computers is based on the scheme below:

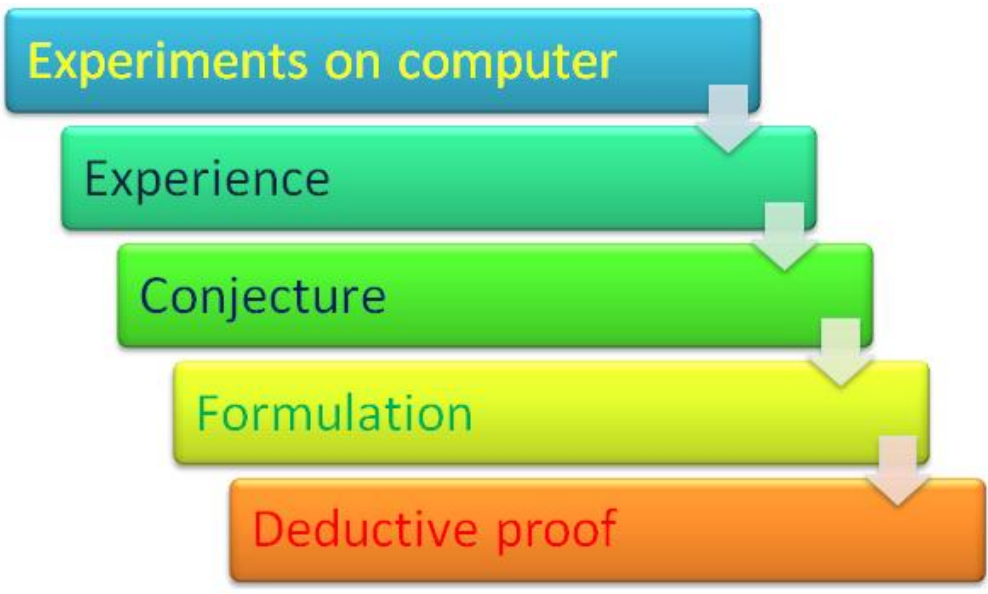

1. Experiments on the computer means that students (or teacher) put up a subject, and instead of one, two or dozen, etc... hundred constructions on paper using a compass, rulers and a pencil, we examine one image on the computer using one of the dynamic geometry softwares. Moving the basic elements of the drawing, everyone can follow the changes on the image, and investigates the nature and the property of the figures.

2. Experience in the student's mind crystallizes after a few images on the computer or constructions or a few sketches in the student's notebook.

3. Conjecture appears in common ideas which may not always be true. Sometimes we have to work out some new special cases. 
4. Formulation of the theorem or content follows after a good conjecture.

5. Deductive proof is the most difficult part, sometimes the teacher has to ask some leading questions to help. Sometimes we have to verify the opposite direction of the theorem, or to find counterexample, that from the opposite condition follows the opposite statement.

This visualization in experimental geometry helps to:

- develop/improve spatial and perception skills;

- increase intuitive skills, gain insight;

- predict theorems and the properties of geometrical figures, discovering new patterns and relations;

- increase divergent thinking and the checking of new ideas;

- recognize "visible" proofs and suggest approaches for formal proof;

- motivate students' active participation;

- increase the students' enthusiasm.

The disadvantages of computer aided teaching are :

- a decrease of desire to prove the theorems;

- the deficiency of mathematical rigorousness since "everything is visible on the drawing";

- some students find the computer difficult to use therefore they become frustrated;

- it is still expensive for schools.

There is a 90-minute-long written exam in the school every three months, which contains tasks that have been taught in the previous three months, i.e problems to solve and to prove. The chosen tasks are from our course book [16], which was translated into Hungarian by me. There are students from all over Vojvodina in our school, with different backgrounds, from different schools and teachers. But mostly are talented in mathematics, as all of them have passed the entrance exam and been accepted into this special grammar school to be taught in the Hungarian language, which is unique in Serbia.

In Schoenfeld's [24] we find the four categories of mathematical behavior:

- Resources are the body of knowledge that an individual is capable of bringing to bear in a particular mathematical situation. Our students come from many different cities and municipalities in Vojvodina. Some of them learned mathematics in Serbian. They had courses that prepared them for our entrance exam, but their primary knowledge is very different. They usually need differential preparation and teaching to develop. 
- Heuristics are rules of thumb for effective problem solving. They are fairly broad strategies for making progress on unfamiliar or difficult problems. Visualization helps students find and investigate special cases, to exploit analogies, to explore different properties and to "work backwards". The first generations could only use their own imaginations and drawings on blackboard and paper. New generations gained experience in the visual perception of exploration. Observing specific cases, such as equilateral, isosceles and right angle triangles, or choosing one of the elements of a figure as a special value ( after which the others are easily calculated ), then one can split the given problem into subproblems, each of which is an easier but related problem, thus leading to the complex solution. Subsequently one can formulate a conjecture of the theorem, and can prove it. The straightforward solution of a Pólya's geometry problem by means of an easier, related problem calls for

1. knowing how to use the right strategy;

2. knowing the appropriate strategy-versions for that problem;

3. generating appropriate, easier, related problems;

4. assessing the likelihood of being able to solve and exploit each of the easier problems;

5. choosing the right one;

6. solving the chosen problem;

7. exploiting its solution [19].

- Control deals with the question of resource management and allocation during problemsolving attempts. The old group, before I began using visualization, could not be sure in the accuracy of their solutions in every case, because drawings on paper were not sufficiently precise, despite the students' accurate work. It was easier to measure some elements and to construct difficult figures using DGS. The new group tried to move basic elements on the computer's construction and was able to find out how these movements and transformations change the given figure.

- Belief systems are one's mathematical world view, the perspective with which one approaches mathematics and mathematical tasks. The old group didn't have visualization; their imagination was the only thing they could use in solving the problems. The new group learned how to analyze some problems and find a "tool" that helped them understand the unfamiliar questions because each problem can serve as an archetype for a large class of problems solved by similar techniques, although the key to each one is different.

The two major questions in the teaching of geometry are:

1. What does it mean to think mathematically in the solving of geometry problems?

2. How can we help students achieve it?

The teacher's work includes being flexible and resourceful within the discipline, using one's knowledge efficiently and understanding and accepting the tacit "rules of the game [24]."

While the observer is analyzing and searching the students' work he doesn't know how the result was really achieved. One student may not come to understand the problem at 
all, but another student may make unsuccessful attempts to solve the problem. In both cases what the student does and what he produces are two different things.

The students are led step by step through four stages of problem solving during their study of geometry in the school [5].

These stages are:

1. encouraging independent investigation;

2. demonstrating approaches to problem solving;

3. discussing solutions of famous problems from past centuries;

4. describing questions considered by eminent contemporary mathematicians.

I think that teaching geometry in grammar school using computers helps students to think mathematically, critically and to solve problems with great accuracy. It is a tool to find new aspects of the theorems of geometry and in other parts of mathematics. Geometry is interconnected with other disciplines of mathematics and using software in geometry includes the Algebra, Calculus and Analysis, too. It continues with students development in mathematics and their beliefs about mathematics.

In what proportion we can realize the curriculum syllabus from Geometry does not depend on the individual student's ability in mathematics. Sometimes the students' morale in the classroom also influences the achievement and success of the lesson. If there is young leader in the classroom who is pulling the rest of the students along, there exists an opportunity to work on the most complicated problems of the syllabus, either individually or in teams. The classroom's morale is under the influence of some leading students. The teacher's and the students' motivation is as an important factor as the average level of the mathematical ability of the whole class.

The axiom of teaching, the elementary truth from the teacher's point of view is that "Teachers open the door, but students must enter by themselves."

The axiom of learning from the student's point of view is

"Tell me and I'll forget; show me and I may remember; involve me and I'll understand." (Ancient Chinese quotes)

In my opinion their interpretation is that the teacher is able to make things understandable, but students have to learn it. The teacher can motivate the student's imagination and mind, contribute to the student's cognitive development. The teacher can also transmit his/her own enthusiasm to the students, but it is up to them how they use it. 


\section{Teaching and learning mathematical concepts and mathematical creativity}

In our everyday lives a large part of the knowledge we use is acquired directly from our environment and it is not so abstract. The special difficulty in Mathematics and its power resides in its substantial abstraction and universality. Although the basic principles of teaching Mathematics are simple, knowing them is not important to the "recipient" in the communication system (the student), but more necessary for the "sender" (the teacher, who gives the mathematical concepts).

The first basic principle is: we can't teach concepts to students whose level of knowledge is not sufficiently developed to receive those concepts, but if we show many suitable examples, the students can understand the essence of the concept.

The second basic principle is: we must be sure that the student still knows basic ideas, the main points of the new example. Geometry looks like an environment where it is worth examining visualization and symbols, because drawings are of great significance. These symbols have a more abstract meaning than the visual representations of some objects.

The difference between the two kinds of symbols - the picture and the word - is that the picture looks like the given object, but the word does not have to be the same. In summary, the opposite characteristics and the characteristics complementing each other [26] are:

\begin{tabular}{|c|c|}
\hline Visual & Verbal-algebraic \\
\hline abstract space characteristics & abstract properties independent from space \\
difficult to explain using words & easy to explain using words \\
demonstrates individual thinking & demonstrates socialized thinking \\
integrated, shows structure & analytical, shows details \\
simultaneous & one after the other (one by one) \\
intuitive & logical \\
\hline
\end{tabular}

The child's mathematical thinking means many things. It is partly a contact with an adult, a solo-activity with its own problems and strategies for its solution, or an informal idea of his/her own intuitions. He/she sees mathematics as an arbitrary series of actions, a set of tricks planned as an obstacle. That is why we, the teachers, have to examine the approach to the central problem of the cognitive and educational process.

Suppes [28] formulated the antinomies in the foundations of teaching mathematics which are:

- The Antinomy of Adjustment. On the one hand, that the school, particularly elementary school, should be organized to provide the maximum amount of personal and social adjustment for the individual child. On the other hand the school should be organized to provide the maximum amount of achievement on the part of the 
individual child. When these two principles are joined with some fairly widely accepted factual statements, an antinomy or contradiction is easily derived.

- The Antinomy of Method. In teaching we should maximize learning and problemsolving techniques independently of content, and the selection of curriculum material should maximize student involvement and motivation. On the other hand we should maximize the content of the curriculum in order to prepare students for specific jobs with specific skills and to provide them with a particular historical and cultural background.

- The Antinomy of the Child. School should be centered entirely around the child and not around the curriculum. On the other hand schools should, at all times, emphasize the curriculum because teaching the curriculum is the proper function of the schools, while the personal development of children is the responsibility of other segments of society, especially of parents.

- The Antinomy of Freedom. Schools should endeavor to develop freedom of speech, thought, and choice. On the other hand schools should endeavor to develop a sense of discipline and criticism that satisfies the highest possible intellectual standards.

These contradictions are present in our school, too. At the beginning of their education in the Bolyai Grammar School students must pass an entrance exam with a test of twelve (rather difficult) tasks. Every task gives five multiple choice answers $(A, B, C, D$ and $E$, out of which one is true), and the answer $N$ : "I don't know."

This kind of exam allows some students with a low ability in mathematics to complete the exam successfully and he or she could be on his or her way to graduate from the school. Almost every class contains one or two "lucky" students, who later cause problems in education. The visualization I made for teaching geometry does not always help them. But there are two or three highly talented students in every class with great experiences in mathematical competitions. They like visualizations; they give very fast answers and proofs to given problems. That's why during every lesson, especially in geometry, differential education in present, which means the lesson plan must be made up of a range of activities from easy tasks to complicated problems. While some students are still working out the basic tasks, others think about the solution to complicated problems. These facts reflect the four dimensions of teaching geometry: the scientific, pedagogical, psychological and constructional dimensions. The teacher must give enough space and possibility for the student's creative work.

\section{The pyramid of talented students in mathematics:}

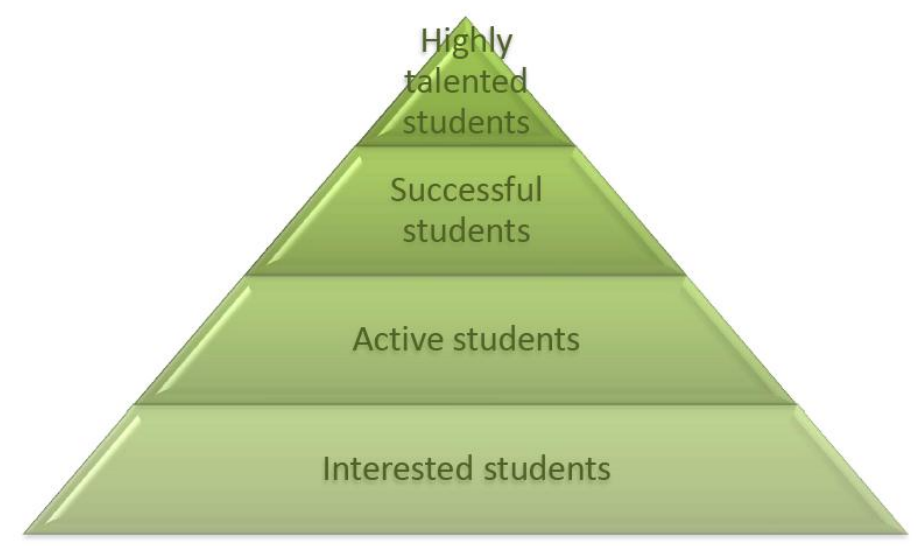


The definition of the groups:

- A talented/gifted student has a high ability in mathematics, asks questions, is curious and intellectually dependent, has original ideas - a flash of genius, makes primary products, works out abstract concepts;

- A very successful student performs the learned contents easily, uses them, applies the known themes;

- An active student is open eyed, aware, gives precise answers to the teacher's question, internalizes the knowledge to himself/herself, is diligent;

- An interested student preforms the tasks, works very hard, is satisfied with his/her own achievement, understands new ideas.

The make up of the classes is presented by the scheme above as the pyramid of gifted students in mathematics. In every class there is at least one student with high ability (yellow star above at the top), two or three students who are very successful (green little pyramid), four to six students are active in every lesson (blue), but the big base of the pyramid (purple), the biggest part of the class, is the group of interested students. These borders between the groups in the talented pyramid are fluid some extent and boundaries relate to each other. Some students even "hang out of the lines", they could not be categorized in the pyramid. In my opinion, a few of the very clever students cannot get to the top of the pyramid according to this classification. The reason might be family problems that may lead to psychological irregularities or sometimes social and environmental factors are in the background of the students' behavior. This method, using computer visualizations during lessons, is a motivation factor in the students' work. We are looking back to the theorems of the previous year; students can remember the main statements in synthetic form. In my opinion, students like this method of the teaching-learning process and they work with great enthusiasm.

Visualization on the computer is made for them. In my opinion the method I use is perfect for students from that "interested" and "active" students' groups and my own experiences prove this statement. However, the teacher has to be creative, motivated in teaching/learning, very tolerant and patient, a manager-type, interested in the teaching/learning process, encouraging and has to have good professional knowledge.

As students progress through our educational system their interest in mathematics and in geometry (in elementary school geometry vanishes from the mathematical lessons) diminishes. However, our school is specialized to meet the needs of mathematical talents, and we have to find almost every little mathematical talent in Vojvodina. Literature suggests that mathematical talent is most often measured by speed and accuracy of a students ability to calculate with little emphasis on problem solving and pattern finding and no opportunities for students to work on rich mathematical tasks that require divergent thinking [15].

Balka [2] formulates mathematical talent in some ways:

The resulting criteria to measure creative mathematical potential are the following:

1. The ability to formulate mathematical hypotheses concerning cause and effect in mathematical situations; 
2. The ability to determine patterns in mathematical situations;

3. The ability to break from established mind sets to obtain solutions in a mathematical situation;

4. The ability to consider and evaluate unusual mathematical ideas, to think through the possible consequences for a mathematical situation;

5. The ability to sense what is missing from a given mathematical situation and to ask questions that will enable one to fill in the missing mathematical information;

6. The ability to split general mathematical problems into specific sub problems

During the four years of education in the grammar school, we witness how changes in students' beliefs about the nature of mathematics can result in changes in their performance. When students graduate and leave the grammar school, the hope remains that the teacher's work was successful. I expect growth of achievement on the graduating exam. During the first six years of teaching geometry using computers my experiences show that at the end of their secondary education our pupils receive the kind of tools and knowledge which help them solve problems in their own way with special skills, and find new solutions for technical problems as engineering experts. They learn to apply computers and visualizations to their own problems far from geometry and mathematics in every area of life and their mind is open to new discoveries in the world - as written in the "Mathematical Discovery" [20].

Teaching geometry using visualizations on computer prepare the scientist of the future to try every special cases of the new problems to find and discover our environment and life.

Paulo Coelho writes in the "Witch of Portobello",

"What is a teacher? I'll tell you: it isn't someone who teaches something, but someone who inspires the student to give of her best in order to discover what she already knows." 


\section{Geometry I, Planimetry}

The Serbian Ministry of Education is the author of the plans for the teaching of Geometry. The plans contain subjects of basic synthetic geometry. The program Geometry I was built following the introduction of basic geometrical knowledge. There are:

Isometric transformations: rotation, reflection, symmetry, translation.

Dilatation, symbol $H_{O, k}$, where $O$ is the center of the dilatation, $k$ is the ratio.

Inversion, symbol $\Psi_{i}(O, r)$, where $O$ is the center and $r$ is the radius of the inversion of circle $i$.

One of the best problems is the theorem of the Euler's line.

In the following problem we can follow the students' cognitive development and the progression of thought solving a geometry problem using computer visualizations and elementary proofs.

\subsection{The task}

The given problem was Euler's line. The preliminary knowledge of the students contained the important points of the triangle, the center $O$ of the circumcircle (blue), the orthocenter $H$ (red), the center $S$ of the inscribe circle and the centroid (barycenter) $T$ (green), which were studied during two previous lessons.

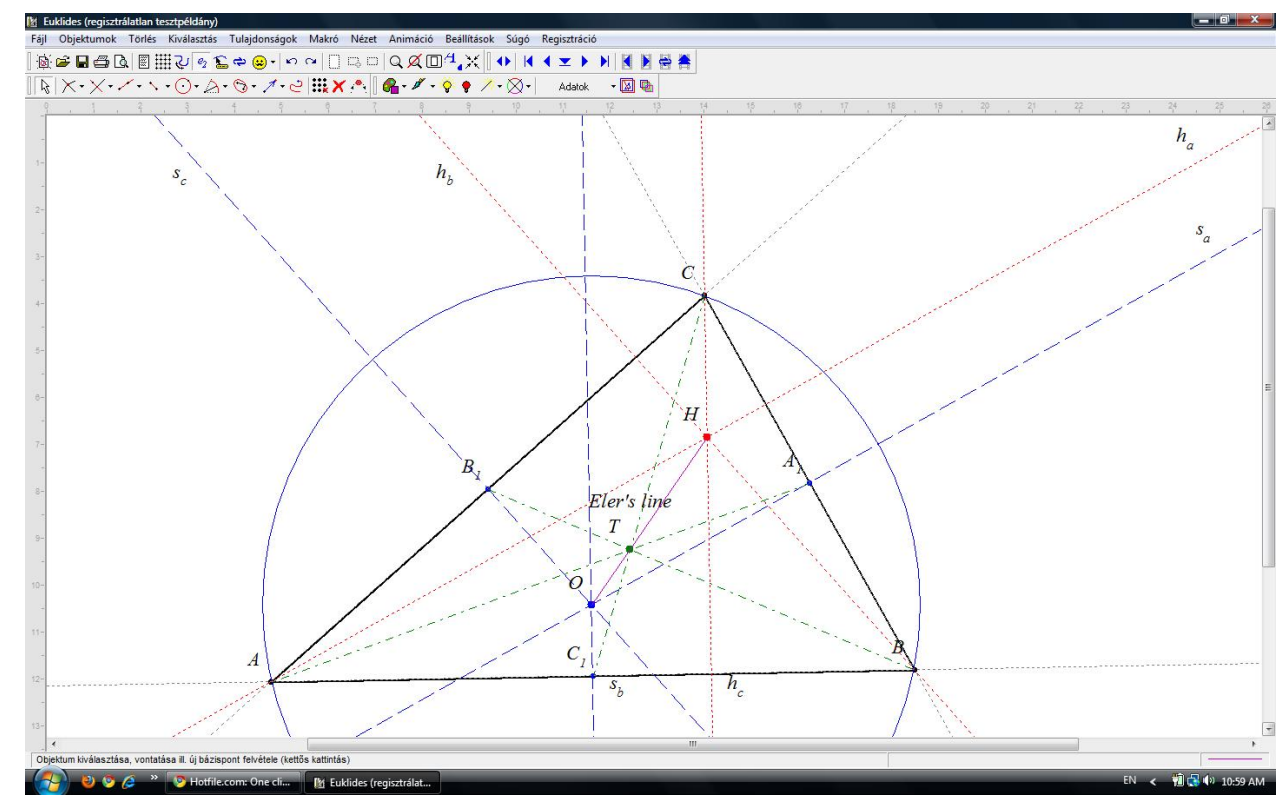

First, the definition of the important points was given, and we constructed them on the acute triangle. The next step was the proof of the task, to show the related theorem and properties correctly. 
The third step was the construction of that important point. Changing the basic elements we can examine the special cases of the isosceles, equilateral and right-angled triangle. The homework was the case of the obtuse triangle. The students were asked to make a good construction with adequate accuracy. This homework was checked by me, and I pointed out incorrect details and imperfect constructions.

The examination contained three parts (phases):

1. Visualization on the computer;

2. Comprehensive tasks for assessment and evaluation;

3. Revision after the winter vacation.

When we began work on the proof of the property of the Euler-line [OTH], my students knew the basics of vector algebra such as their addition and multiplication with real numbers, and we had proven the Hamilton-theorem:

$$
\overrightarrow{O B}+\overrightarrow{O C}+\overrightarrow{O A}=\overrightarrow{O H}
$$

as well as vector equality:

$$
\overrightarrow{C H}=2 \cdot \overrightarrow{O C_{1}}
$$

if $C_{1}$ is the midpoint of the segment $A B, O$ is the circumcenter, $H$ is the orthocenter of the triangle $A B C$.

\subsection{Visualization on the computer}

After we had given definitions of important points of the triangle, (they had had preliminary knowledge about these mathematical concepts), we drew them using DGS.

\section{Experiments on the computer}

The first task was to draw a triangle with vertices, and its sides. Then I asked them to construct the important points of the triangle.

Students were requested to use different colors to mark these points, $S$ as the center of the inscribed circle, $O$ to the center of the circumcircle, $H$ as orthocenter, $T$ as the centroid of the triangle. Details of the image were chosen autonomically, independence of the "artists" is methodologically motivated.

\section{Experiences}

The next step was the moving of basic points, the vertices of the given triangle.

Teacher: What happened to these important points? How did they move? Where were they in different cases? Check their positions!

There were a dozen nice and successful drawings, but there was no correct answer yet.

Teacher: Let us see the special cases!

They recognized the isosceles triangle, the equilateral triangle (there is a function to measure edges and angles of the triangle), and the right angle triangle. They had a chance to 
examine the cases of acute and obtuse triangles.

\section{Conjecture}

They were able to form a theorem about the position of these important points, as if the triangle's obtuse points $O$ and $H$ were on different sides of the triangle or outside it. Then I gave them a little help:

Teacher: Hide point $S$, the center of the inscribed circle of the triangle for a moment! Connect points $O$ and $H$ !

Their answers came very fast: The centroid was on this line $O H$.

Students found the answers to these questions themselves, that the points $O$ the center of the circumcircle, $H$ orthocenter, $T$ the centroid of the triangle were always on the same line.

At this moment, we were able to define Euler's line, as a line which contained the centroid, the orthocenter and the circumcenter of the triangle. They were satisfied (me, too!) and with great enthusiasm they made a few animated drawings.

\section{Formulation of the statement}

They measured the length of the segments $H T$ and $T O$, and they found equality:

$$
2 \cdot \overrightarrow{O T}=\overrightarrow{T H}
$$

The following exclamation was the evidence of the joy of discovery: "Eureka".

\section{Deductive proof:}

After formulation we introduced some deductive synthetic proofs, using vectors, and the similarity of triangles $\triangle A H T$ and $\triangle T O A_{1}$.

Here are some examples of their works on the computer:

- Student E.A. constructed his drawing of the Euler-line very well, this example is on the acute triangle, where all important points are inside the triangle.

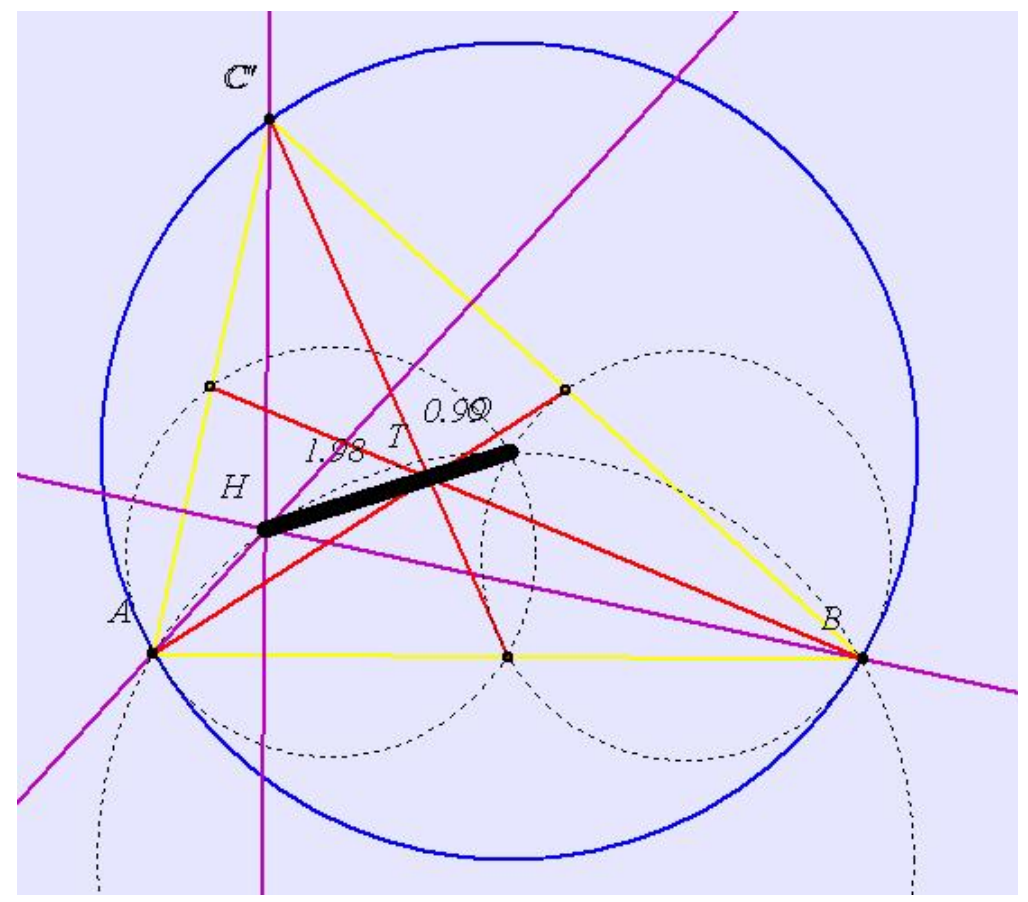


- Students B.A. and F.E. created an obtuse triangle, where one can see that the orthocenter of the triangle and the circumcenter are on the opposite side of the triangle

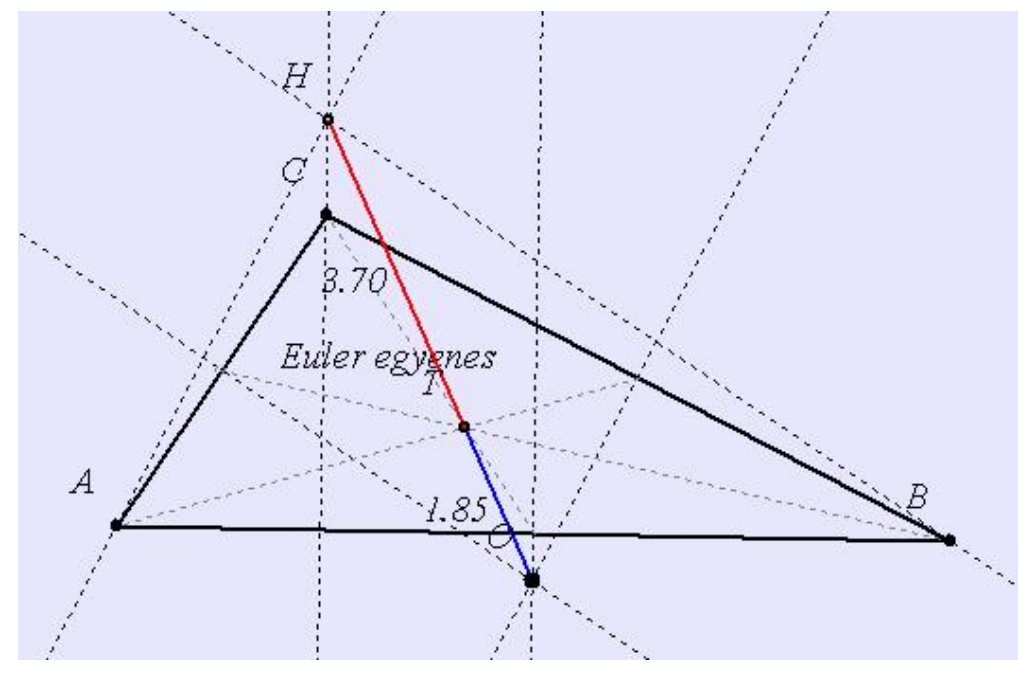

- Student T.S. drew the right-angled triangle, where the orthocenter is the vertex of the right-angle, and the circumcenter is the midpoint of the hypotenuse.

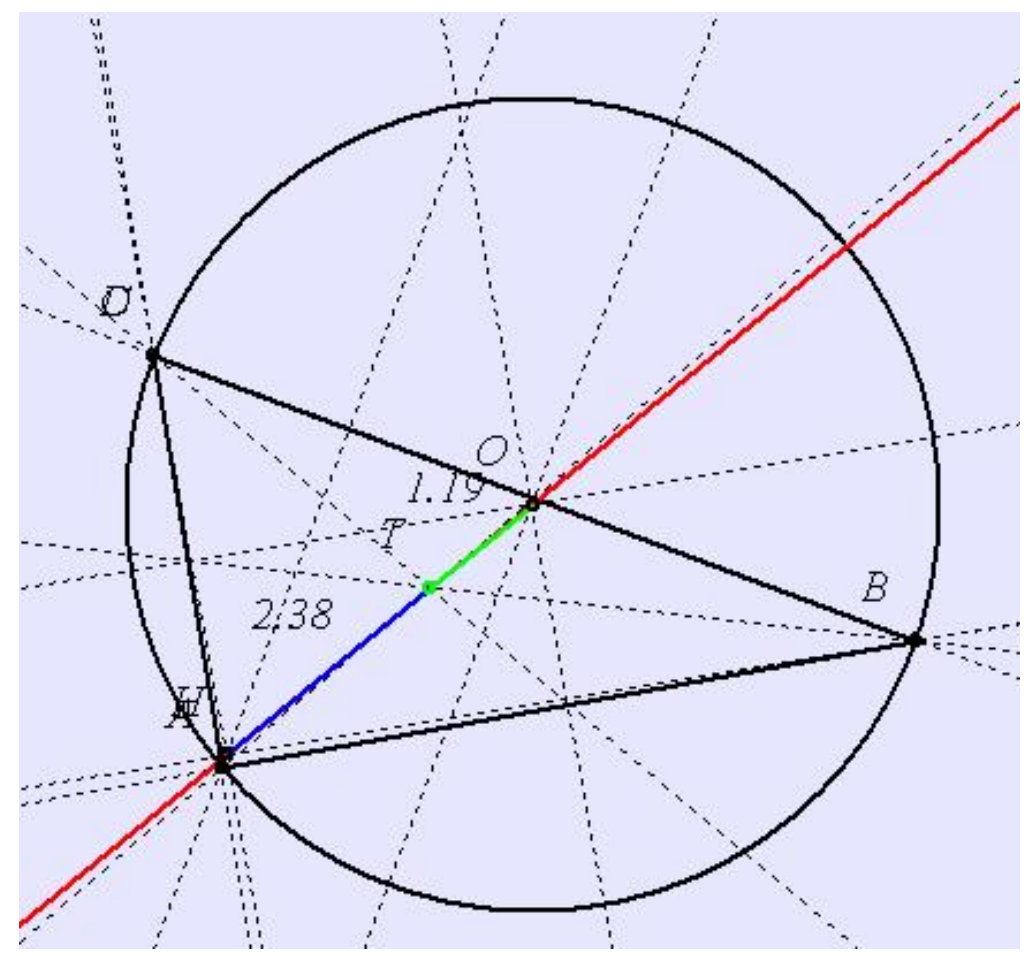


- Student N.A.E. drew a triangle without any labels, the important points are unknown, although well constructed.

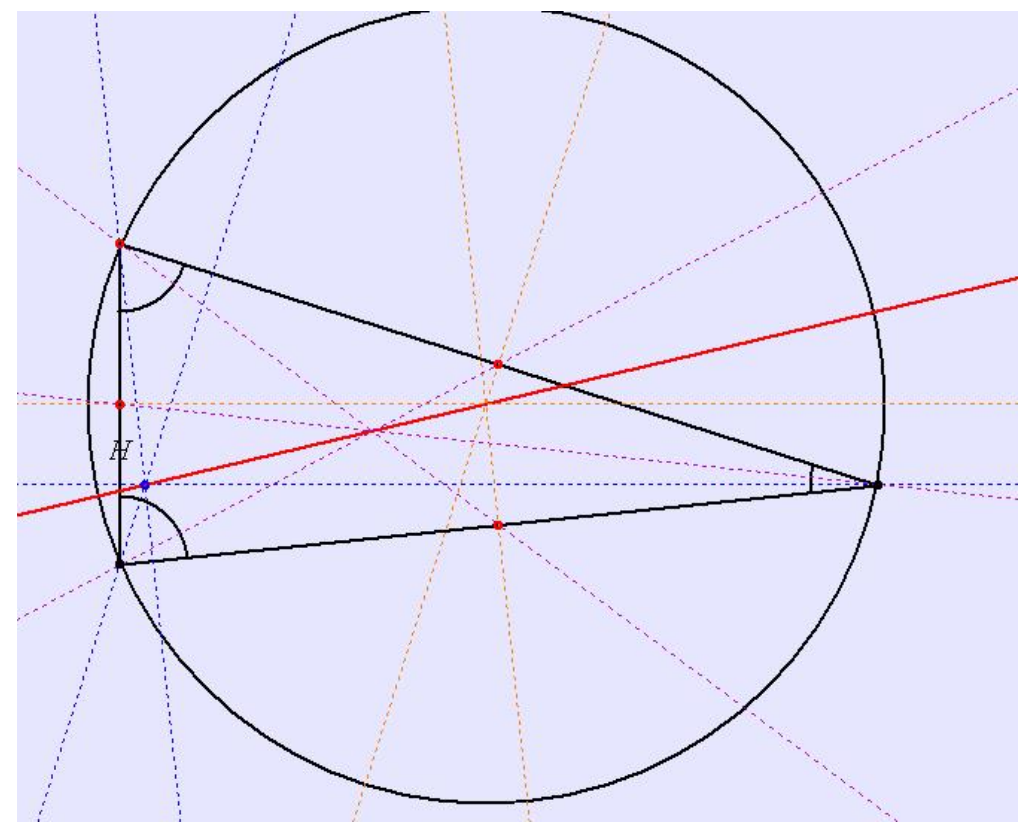

- Student N.L. drew this picture as the Euler-line. At the end of the lesson he was able to make only this one. But he recognized his mistakes during the next lesson, and made a new, better picture with our help.

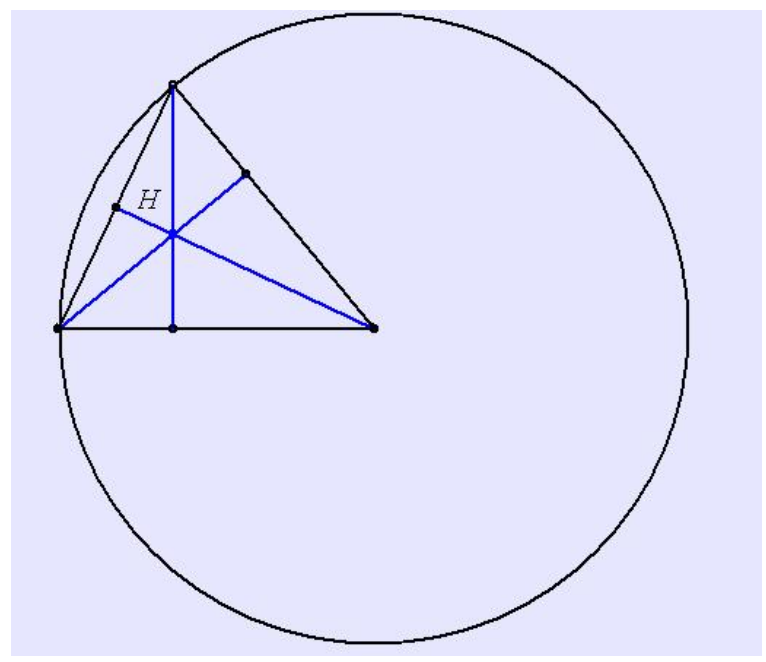

My experiences are that if students can experimenting on the computer, they do not need to memorize theorems, as they can always verify them on the computer images. The students must interiorize that visualization on computers is the first step of solving problems algorithmically. This method deepens the conjecture of the theorem. Verifying the opposite direction of the statement allows students to understand the inverse theorem. Computer visualization is a genius tool, "playing" on computer with geometrical figures and colors discovers new connections. 


\subsection{Comprehensive tasks for assessment and evaluation}

Comprehensive tasks for assessment and evaluation were used to compare students' knowledge at this level of learning. There was a task to create a classical construction using a compass and rulers. My aim was to develop their motor skills, to show the mistakes in drawing and to raise the level of their accuracy in construction. Here are some examples of their works:

- Student H. Z. created a good construction, with appropriate labeling, and used the colour red for important details, the important points of the triangle, $H$ (orthocenter), $T$ (barycenter), $O$ (circumcenter). It is an obtuse triangle in which we can see that the orthocenter and the circumcenter are on the opposite sides and outside of the triangle. (His only mistake was forgetting the capital letter in Euler's name.)

He marked only Euler's line.

- Student B.A. drew the Euler-line with the Euler-circle, showing nine points on it, but labeling is odd, because there is $\frac{H B}{2}$ instead of $B_{2}$, for example. Although that particular label shows understanding of the concept, that this point is the midpoint of the segment $H B$. This construction is a very precise and acute drawing with a good inscribed circle. 


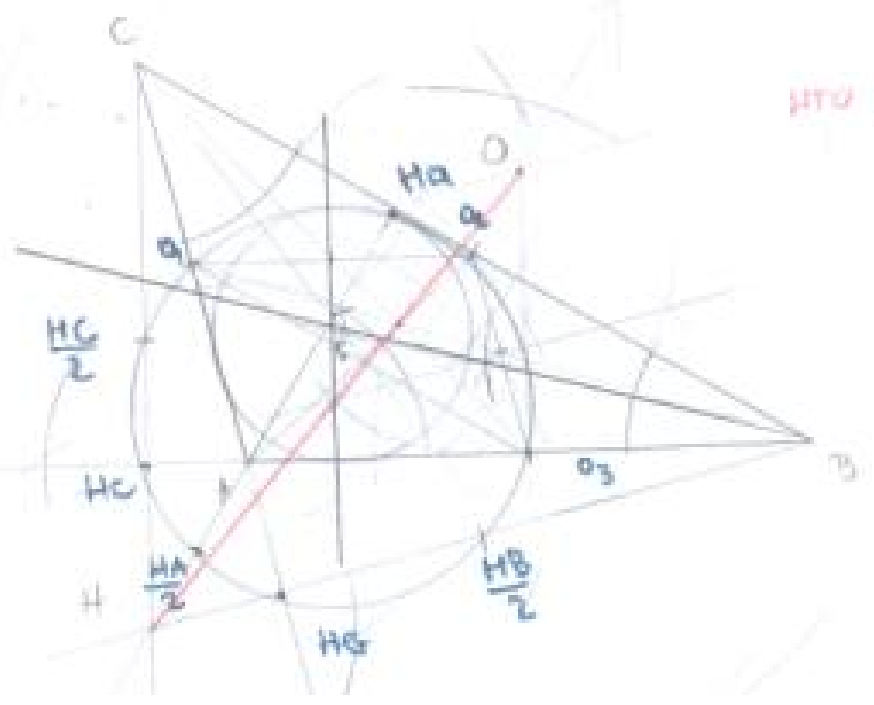

- Here is a very good construction from F.E. The edges of the triangle are thickened and highlighted, there is adequate labeling and the construction is appropriate and precisely drawn. The quality of the constructional instruments (tools) can influence the results.

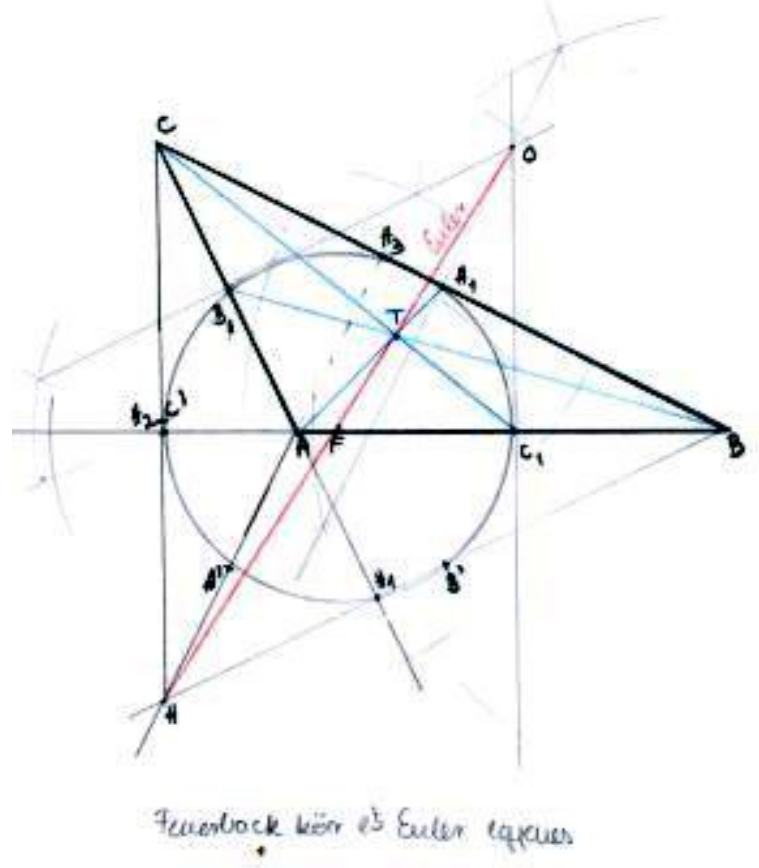


- Student V.I. was not accurate yet, and he paid no attention to the construction, but he has a "mathematical brain". He is talented, demonstrated by how he performed during the last few competitions. This drawing is not of appropriate quality; there is no inscribed circle, no labeled vertices. However the main concept, the Euler's line, is acceptably good.

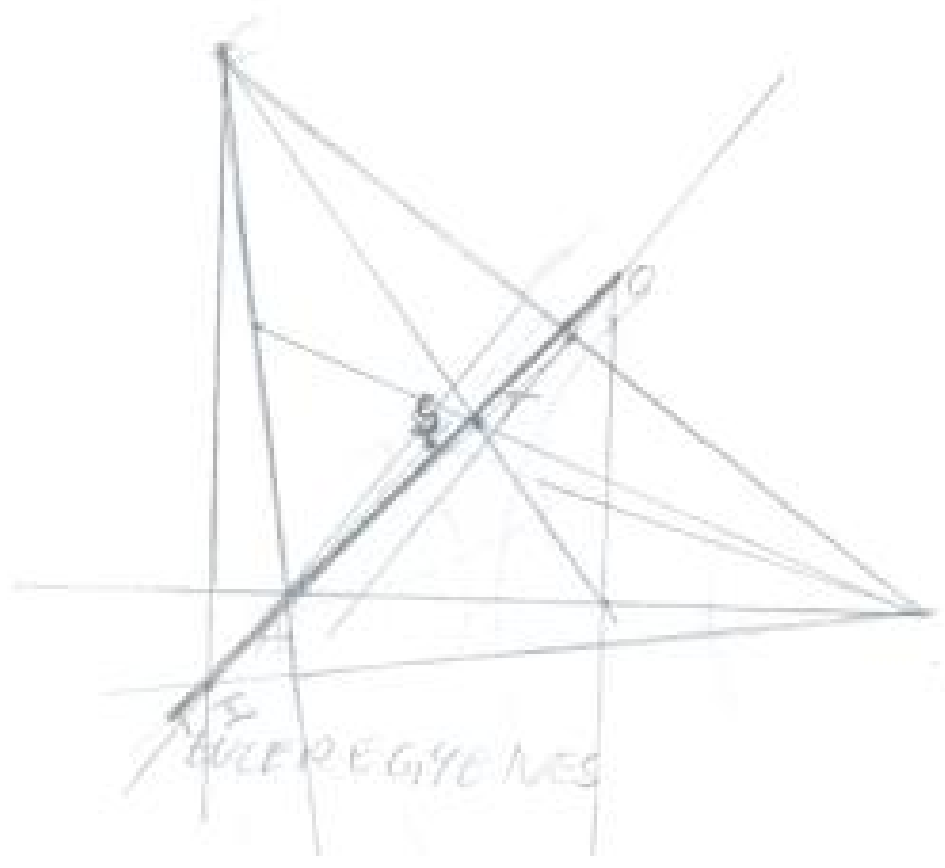

- Student L.I. has forgotten that this drawing had to be done using an obtuse triangle. Accuracy here is not important, although he had an adequate knowledge of construction, shown beside the picture.
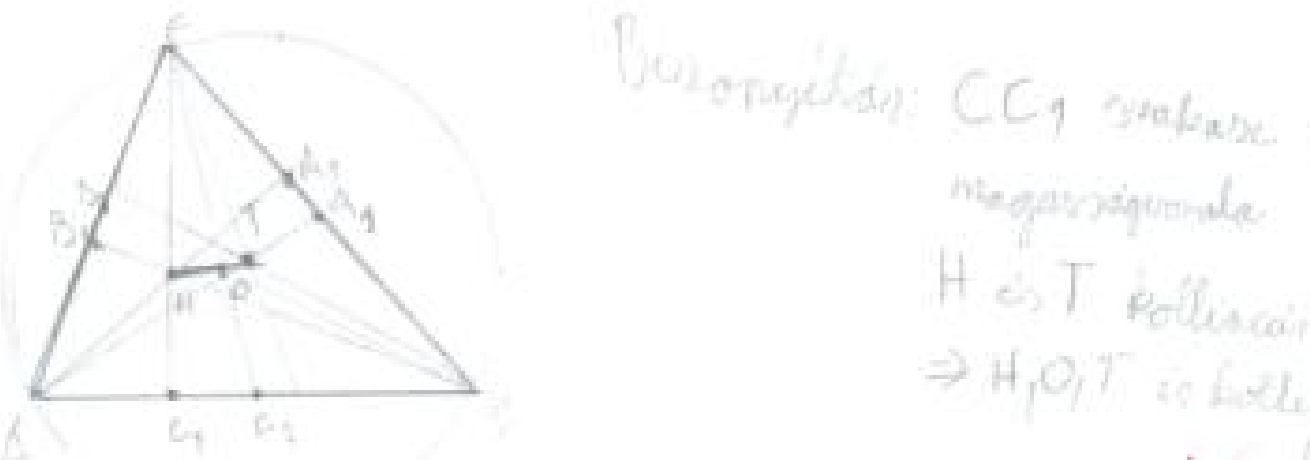

Translation: Proof: segment $C C_{1}$ is an altitude of the triangle $A B C$, points $H$ and $T$ (orthocenter and barycenter) are collinear points. 


\subsection{Revision after the winter holiday}

Review after the winter holiday is always in our teaching plan as it allows students to practice theoretical proofing. As the Latin proverb states,

"Repetitio est mater studiorum (repetition is the mother of knowledge)"

During the winter holiday the students' mathematical knowledge settles and develops, but the student's mind is full of other perceptions, and details can be forgotten. I always emphasize the simplicity in deductive proof, to keep the pure essence, the main idea of taught, which means to understand and respect mathematical intelligence and the beauty in it.

The images below are the pupils' work. The subjective classification of the works is based on mathematical intelligence, which is in accord with the students' self-evaluation. Here are some examples:

- The best work by K.T. He is extremely talented in mathematics. He works very hard. His solution was done on the basis of the similarity of the triangles $C T H$ and $T O C_{1}$. This is excellent work and the nicest and simplest proof of the property of the Euler's line.
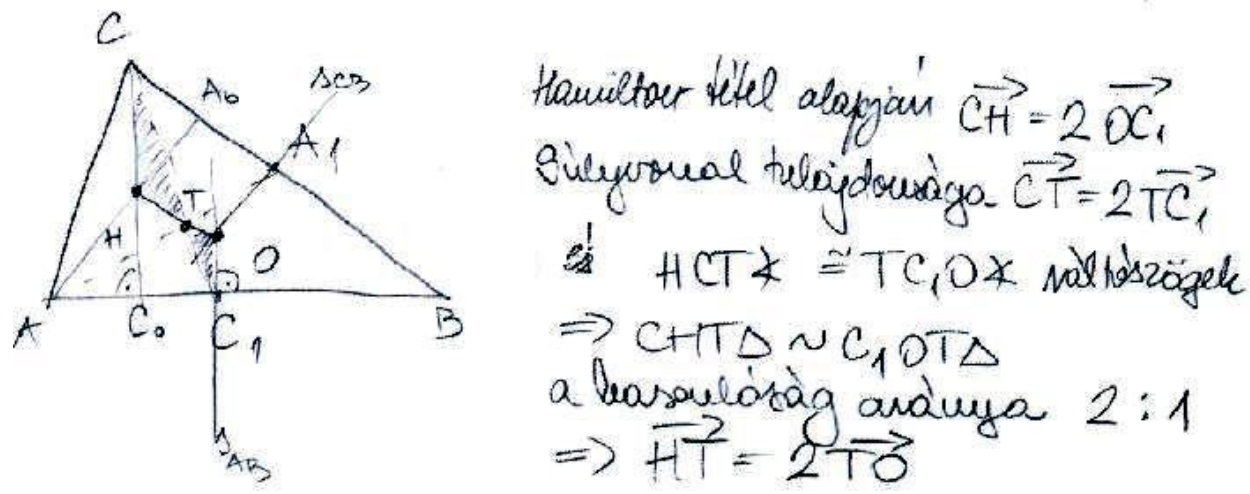

Translation: Based on the Hamilton-theorem:

$$
\overrightarrow{C H}=2 \cdot \overrightarrow{O C_{1}} .
$$

Median line :

$$
\overrightarrow{C T}=2 \cdot \overrightarrow{T C_{1}}
$$

and angle $\mathrm{HCT}$ is equal to angle $\mathrm{TC}_{1} \mathrm{O}$ as alternate angles, that means that triangles $C H T$ and $C_{1} O T$ are similar, the ratio of similarity is $2: 1$, this means

$$
\overrightarrow{H T}=2 \cdot \overrightarrow{T O} .
$$

- A solution that was well done by B.D. He chose the proof by vectors that had been shown during the previous lessons, but his stage fright prevented him from solving it without error. He messed up one coefficient, although he knew the final 
result. Here, the vector equality was applied on the median with the midpoint and the centroid, he used the property:

$$
\overrightarrow{O B}+\overrightarrow{O C}=2 \cdot \overrightarrow{O A_{1}}
$$

as well as the proportional division of the vector and the Hamilton-theorem, but he wrote sign $O$ as the center of the inscribed circle. It was the only little mistake in his work.

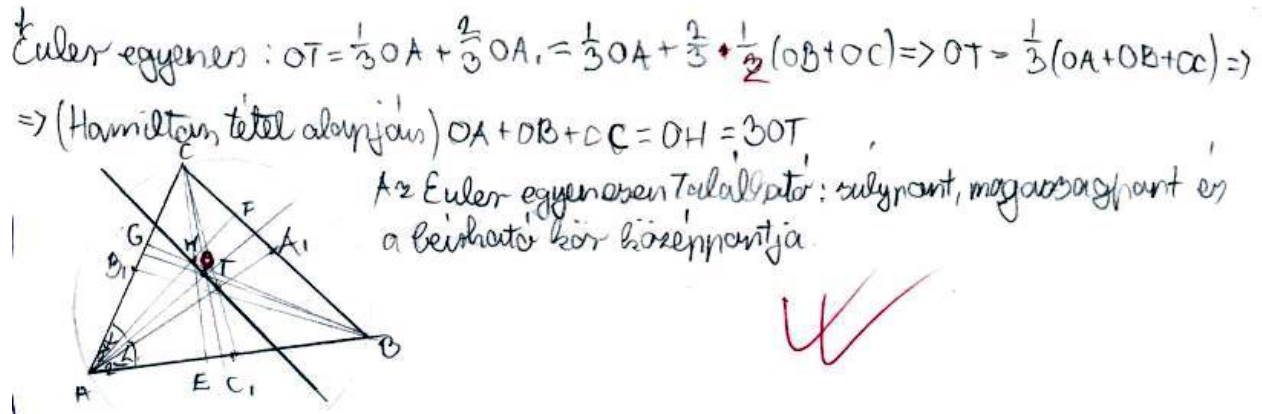

Translation:Points on the Euler's line: barycenter, orthocenter and the center of the inscribe circle

- $\boldsymbol{A} \boldsymbol{g o o d}$ solution V.A. She is one of our greatest "little mathematicians". Last year she won second price in the "Fekete Mihály" Mathematics Competition organized by our school. She is very assiduous and conscientious which is why she prepared very hard for this work which was evaluated. She asked H. M., a student from the fourth grade, to help her with the preparations. H. M. has won every great mathematical competition in Serbia and some international competitions in Mathematics, Computer science and Physics. He is a genius. He showed her his own solution using the scalar product of vectors, which was an unknown concept to her. In his solution he used the feature according to which the two vectors are perpendicular to each other if their scalar product is equal to zero. She has not learned these concepts yet and she was trying to remember them without truly understanding.

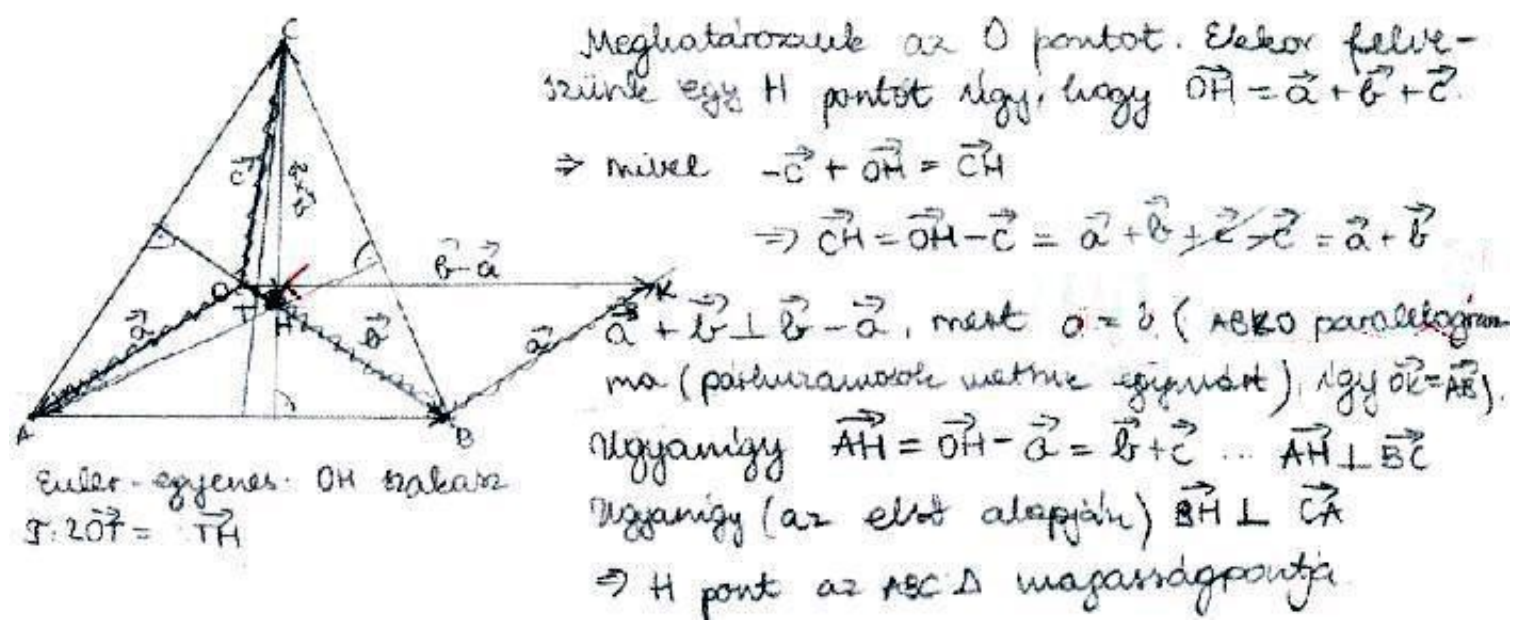

Translation: We construct(order) point $O$. Then construct point $H$ to be

$$
\overrightarrow{O H}=\vec{a}+\vec{b}+\vec{c} .
$$


Because

$$
-\vec{c}+\overrightarrow{O H}=\overrightarrow{C H}
$$

that means

$$
\overrightarrow{C H}=\overrightarrow{O H}-\vec{c}=\vec{a}+\vec{b} .
$$

Vector $\vec{a}+\vec{b}$ is perpendicular to vector $\vec{b}-\vec{a}$, because $a=b$ (ABKO is a parallelogram, intersection of parallels) that is why

$$
\overrightarrow{O K}=\overrightarrow{A B}
$$

The same case: vector $A H$ is perpendicular to vector $B C$, similarly vector $B H$ is perpendicular to vector $C A$. Hence point $H$ is the orthocenter of the triangle $A B C$.

- A.T. wanted to have a good solution and applied vector equality, the property of the medians but with the wrong points $O$ (circumcenter) and $S$ (center of the inscribed circle).

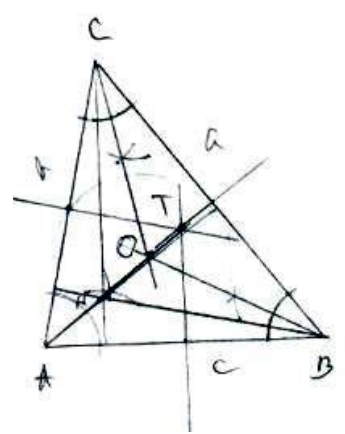

$$
\begin{aligned}
& \overrightarrow{C M}+\overrightarrow{A D} \\
& \overrightarrow{C M}=\overrightarrow{O M}-\overrightarrow{O C}=(\vec{a}+\vec{b}+\vec{c})-\vec{c}=\vec{a}+\vec{b} \\
& \vec{b}-\vec{a} \frac{1}{\vec{b}+\vec{a}} \text { ment a es a equenlc } \\
& \vec{O}=\frac{\vec{a}+\vec{b}+\vec{c}}{3}=\overrightarrow{O M} . \vec{D} \Rightarrow h \\
& d+b=\frac{a+b}{2} \text { aras OM }=2 \overrightarrow{O F} \\
& \overrightarrow{A B}=\vec{a}-\vec{a}
\end{aligned}
$$

- Here is a not so good solution by N.L., who has forgotten almost everything during the winter holiday, did not pay attention to the teacher's appeal for revision.

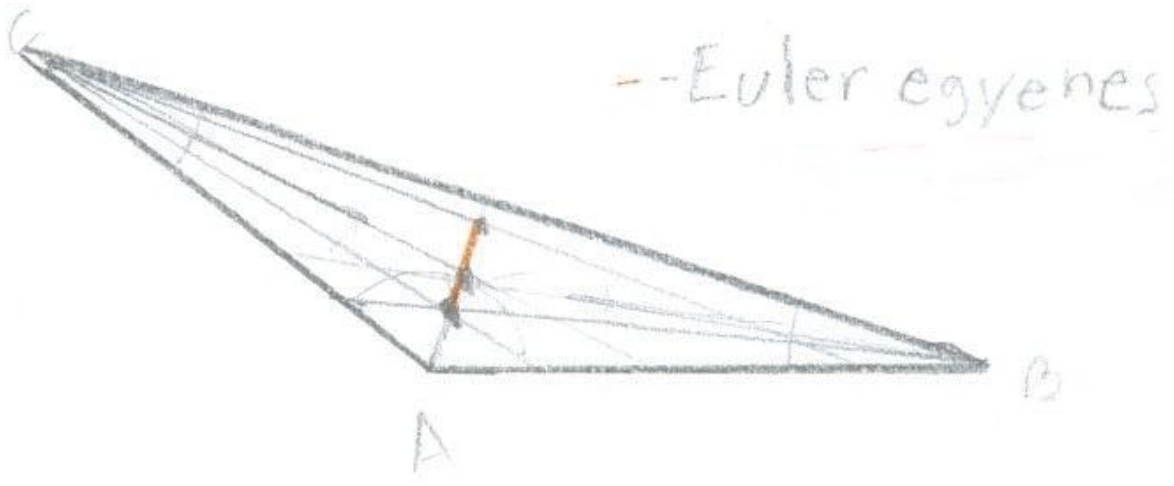




\subsection{Results of Geometry I}

Every three months there is a 90-minute-long written exam in the school, which contains tasks that have been taught in the previous three months, problems to solve and to prove. The chosen tasks are from our course book [16], which is translated into Hungarian by me.

Description of researched groups:

Old $=$ the control group who did not do visualizations on computers, in 2003; there were 20 students.

$\boldsymbol{N e w}=$ the experimental group who had 25 percent of all lessons using computer techniques and visualization, in 2004; there were 14 students.

In both of the groups there were students from all over Vojvodina, with different backgrounds, previous schools and teachers. But they are mostly talented at mathematics as all of them have passed the entrance exam, and were accepted to this special program in the grammar school in Hungarian language.

\subsubsection{The tasks on the second exam}

In these exams usually there are five tasks for marking, and the sixth is for "pleasure". If someone finishes his/her work earlier, and still has time, there is an opportunity to solve the last task marked by star.

1. Prove that medians constructed to the congruent sides of the isosceles triangle are congruent with each other.

2. (a) Construct a triangle using a compass and rulers if three segments are given, $h_{b}$ is altitude from the vertex $B, t_{c}$ is median from vertex $C$ and $c=A B$ is the edge of the triangle ABC.

(b) Construct a right-angled triangle, if the cathetus $a$ and its opposite angle $\alpha$ are given.

3. Let $A B C D$ be a rectangle and points $M, N, P, Q$ on the sides $A B, B C, C D, D A$ respectively, where segments

$$
A M \cong B N \cong C P \cong D Q
$$

are congruent. Prove that the quadrilateral $M N P Q$ is parallelogram.

4. Let $k(O, R)$ be the circumcircle of the $\triangle A B C$, and point $H$ be the orthocenter of that triangle. If point $A_{1}$ is the midpoint of the edge $B C$ then point $A_{1}$ is the midpoint of segment $H D$, too. Construct and prove this!

5. (a) Let $T$ be the barycenter of the triangle $A B C$. Prove that the sum of the vectors from barycenter $T$ to each vertex of the triangle is a zero-vector.

(b) Prove that in every triangle every edge of the triangle is less than the half of the triangles' perimeter.

6. * Construct three regular triangles out of the three sides of the given triangle. For each new vertex of the regular triangle, draw a line from it to the opposite triangle's vertex. What is the conclusion, what can you deduce? 


\section{Solutions:}

1. (a) Condition: Triangle $A B C$ is an isosceles triangle.

Statement: The segments, the medians $A A_{1}$ and $B B_{1}$ are congruent

0.5 point

(b) Sketch:

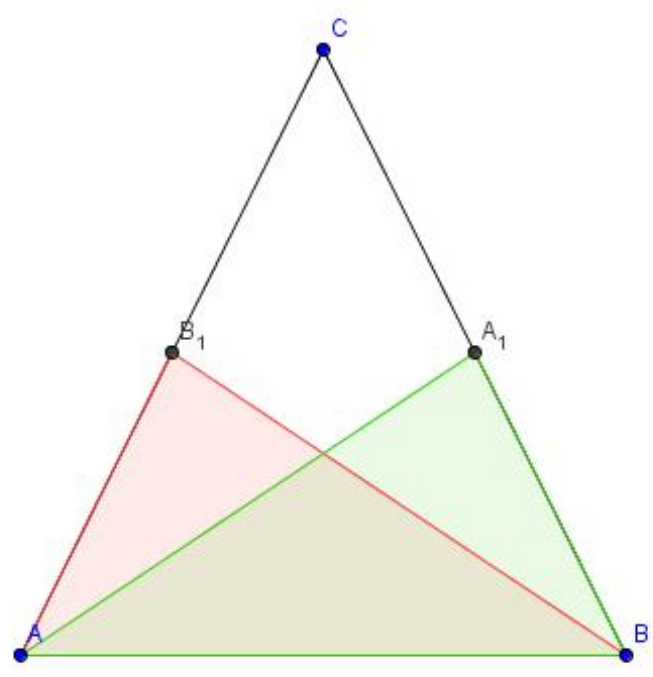

0.5 point

(c) Proof: Let points $A_{1}$ and $B_{1}$ be the midpoints of the sides $B C$ and $A C$ of the isosceles triangle $A B C$, where $A C \cong B C$ are congruent edges. Triangles $A B A_{1}$ and $A B B_{1}$ are congruent, based on the law of congruency called "EdgeAngle-Edge", because

i. the angles on the base side of the isosceles triangle are congruent,

$$
\angle A B A_{1} \cong \angle B A B_{1}
$$

ii. the reflexivity of the congruency $A B \cong A B$

iii. half of the congruent sides are congruent $A B_{1} \cong B A_{1}$

$1+1$ points

summary $0.5+0.5+1+1=\mathbf{3}$ points.

2. (a) i. Analyze: Construct the right-angled triangle $A B D$, where $B D$ is the altitude $h_{b}$ from vertex $\mathrm{B}$ of the triangle $\mathrm{ABC}$. Find point $C_{1}$, the midpoint of the side $A B$. Construct the circle $k\left(C_{1}, t_{a}\right)$ with center $C_{1}$ and radius $t_{a}$. The intersection point of line $A D$ and circle $k$ is vertex $C$. 


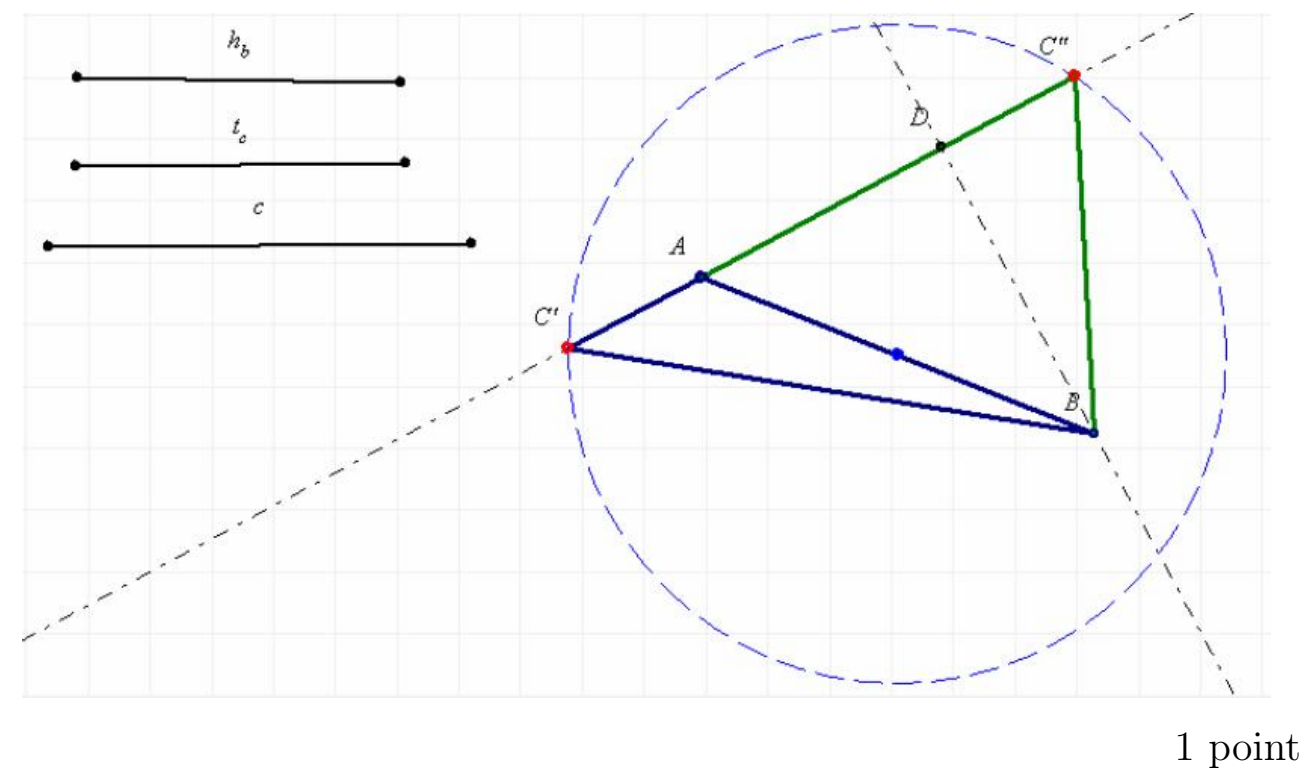

ii. Construction with rulers, compass and pencil,

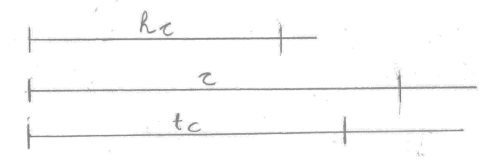

1 point

iii. Discussion: The number of the intersection points of the circle $k\left(C_{1}, t_{a}\right)$ with center $C_{1}$ and radius $t_{a}$ and line $A D$ gives the number of different solutions of the problem. 
$\mathbf{0}$; if $k \cap A D=\emptyset$, then there is no solution;

1 ; if $k \cap A D=\{C\}$, there is only one triangle;

2; if $k \cap A D=\left\{C^{\prime}, C^{\prime \prime}\right\}$, there are two triangles, $\triangle A B C^{\prime}$ an obtuse triangle and $\triangle A B C$ " an acute triangle are not congruent solutions of the given problem.

1 point

summary $1+1+1=\mathbf{3}$ points.

(b) i. Analyze: Construct the segment $a=B C$ and in vertex $C$ the right angle $\angle B C A$ on the segment. Construct the angle $\beta=90^{\circ}-\alpha$ at vertex $B$.

0.5 point

ii. Construction with a compass, rulers and pencil on paper,

1 point

iii. Discussion: If $\alpha$ is an acute angle (it is the only possibility), there is only one solution.

0.5 point

summary $0.5+1+0.5=2$ points

3. (a) Condition: The rectangle $A B C D$ has congruent segments $A M \cong B N \cong C P \cong$ $D Q$

Statement: The quadrilateral $M N P Q$ is a parallelogram.

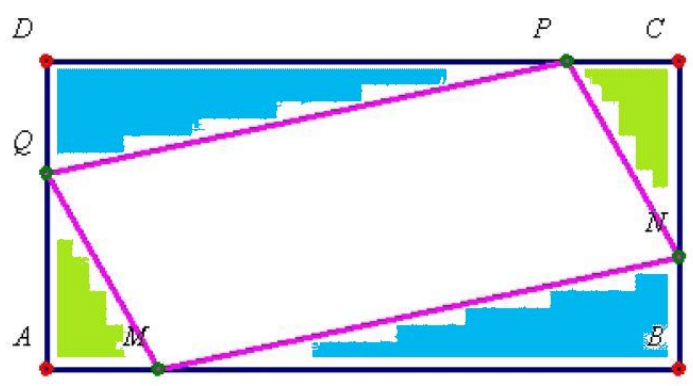

1 point

(b) Sketch: created by student B.K.

1 point

(c) Proof: Right-angle triangles $\triangle A M N$ and $\triangle N C P$ are congruent with two cathetes, similarly $\triangle D P Q$ and $\triangle B M N$. that means the quadrilateral $M N P Q$ has two pairs of opposite congruent sides, and this is equivalent with the definition of the parallelogram, $M N P Q$ is parallelogram.

2 points

summary $1+1+2=4$ points

4. (a) Conditions: $O$ is the circumcenter, $H$ is the orthocenter of the triangle $\triangle A B C$, point $D$ is the opposite point to the vertex $A$ in the circumcircle $k(O, R)$, the midpoint of the edge $B C$ is $A_{1}$ 
(b) Statement: Point $A_{1}$ is the midpoint of the segment $H D$

1 point

(c) Construction

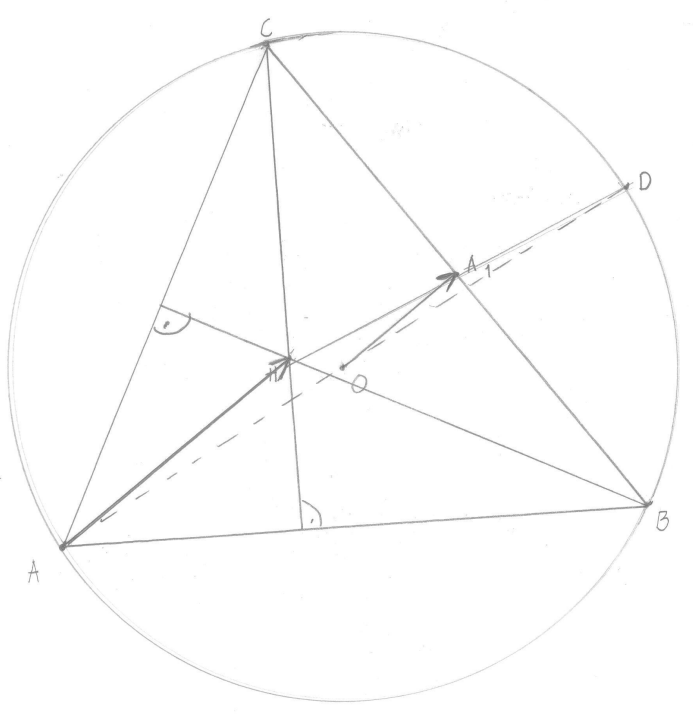

1 point

(d) Proof: From Euler's line it is known that

$$
\overrightarrow{A H}=2 \cdot \overrightarrow{O A_{1}}
$$

0.5 point

Segment $O A_{1}$ is the midline of the triangle $\triangle A H D$, because the circumcenter $O$ halves the diameter $A D$ of the circumcircle $k$, and this means that point $A_{1}$ is the midpoint of the segment $H D$.

0.5 point

summary $1+1+0.5+0.5=\mathbf{3}$ points 
5. (a) Point $T$ is the barycenter of the triangle $\triangle A B C$, that is the intersection point of medians $A A_{1}, B B_{1}, C C_{1}$, where $A_{1}, B_{1}$ and $C_{1}$ are midpoints of the edges of the triangle. Median $A A_{1}$ is expressible in two ways:

$$
\begin{aligned}
& \overrightarrow{A A_{1}}=\overrightarrow{A B}+\overrightarrow{B A_{1}}, \\
& \overrightarrow{A A_{1}}=\overrightarrow{A C}+\overrightarrow{C A_{1}},
\end{aligned}
$$

their sum is

$$
2 \cdot \overrightarrow{A A_{1}}=\overrightarrow{A B}+\overrightarrow{A C},
$$

because $\overrightarrow{B A_{1}}$ and $\overrightarrow{C A_{1}}$ are opposite vectors, their sum is a zero-vector,

$$
\overrightarrow{A A_{1}}=\frac{\overrightarrow{A B}+\overrightarrow{A C}}{2} \text {. }
$$

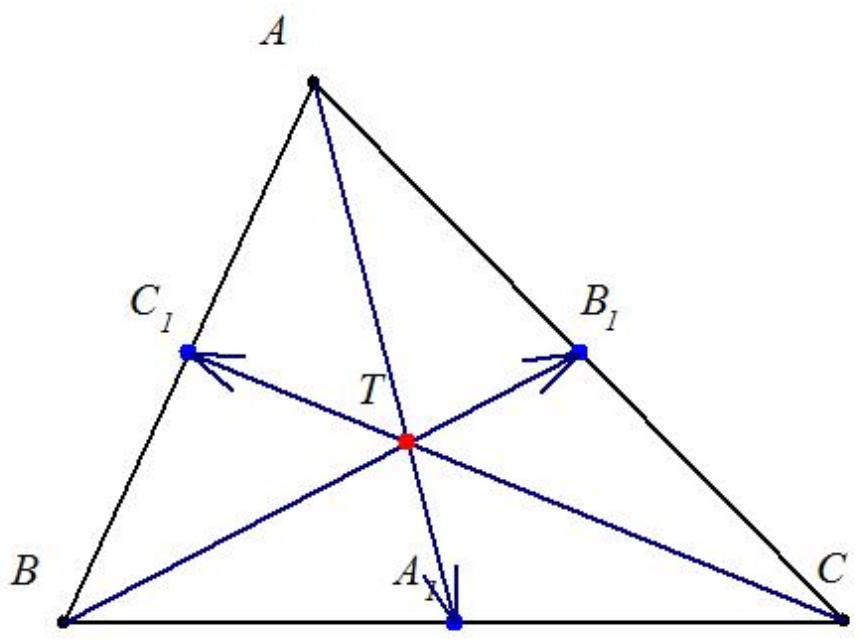

Similarly to the previous, the other medians are:

$$
\begin{aligned}
& \overrightarrow{B B_{1}}=\overrightarrow{B A}+\overrightarrow{A B_{1}}, \\
& \overrightarrow{B B_{1}}=\overrightarrow{B C}+\overrightarrow{C B_{1}},
\end{aligned}
$$

their sum is

$$
2 \cdot \overrightarrow{B B_{1}}=\overrightarrow{B A}+\overrightarrow{B C}
$$

because $\overrightarrow{A B_{1}}$ and $\overrightarrow{C B_{1}}$ are opposite vectors, their sum is a zero-vector,

$$
\begin{aligned}
& \overrightarrow{B B_{1}}=\frac{\overrightarrow{B A}+\overrightarrow{B C}}{2}, \\
& \overrightarrow{C C_{1}}=\overrightarrow{C B}+\overrightarrow{B C_{1}}, \\
& \overrightarrow{C C_{1}}=\overrightarrow{C A}+\overrightarrow{A C_{1}},
\end{aligned}
$$

their sum is

$$
2 \cdot \overrightarrow{C C_{1}}=\overrightarrow{C A}+\overrightarrow{C B}
$$

because $\overrightarrow{B C_{1}}$ and $\overrightarrow{A C_{1}}$ are opposite vectors, their sum is a zero-vector,

$$
\overrightarrow{C C_{1}}=\frac{\overrightarrow{C A}+\overrightarrow{C B}}{2}
$$


1 point

The sum of the medians is

$$
\overrightarrow{A A_{1}}+\overrightarrow{B B_{1}}+\overrightarrow{C C_{1}}=\frac{\overrightarrow{A B}+\overrightarrow{A C}}{2}+\frac{\overrightarrow{B A}+\overrightarrow{B C}}{2}+\frac{\overrightarrow{C A}+\overrightarrow{C B}}{2}=\overrightarrow{0}
$$

$T$ is barycenter, that's why $\overrightarrow{T A}=-\frac{2}{3} \cdot \overrightarrow{A A_{1}}, \overrightarrow{T B}=-\frac{2}{3} \cdot \overrightarrow{B B_{1}}$ and $\overrightarrow{T C}=-\frac{2}{3} \cdot \overrightarrow{C C_{1}}$, therefore

$$
\overrightarrow{T A}+\overrightarrow{T B}+\overrightarrow{T C}=-\frac{2}{3} \cdot \overrightarrow{0}=\overrightarrow{0}
$$

1 point

summary $1+1=2$ points

(b) The triangle inequality gives that every edge of the triangle in smaller than the sum of the other two edges, $a<b+c$ therefore

1 point

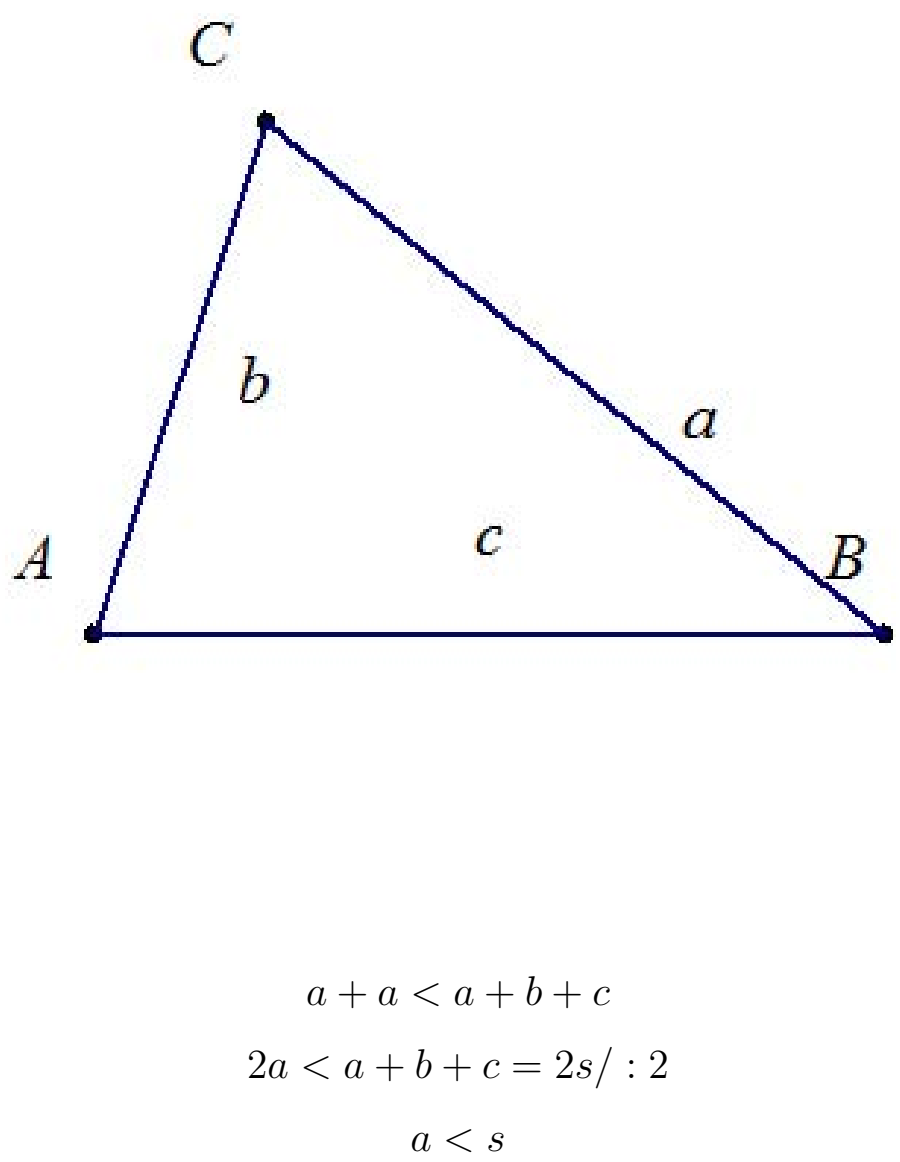

1 point summary $1+1=\mathbf{2}$ points

* These three lines $A N, B P$ and $C M$ intersect at one point, called the Fermat point or Toricelli's point of the triangle. 


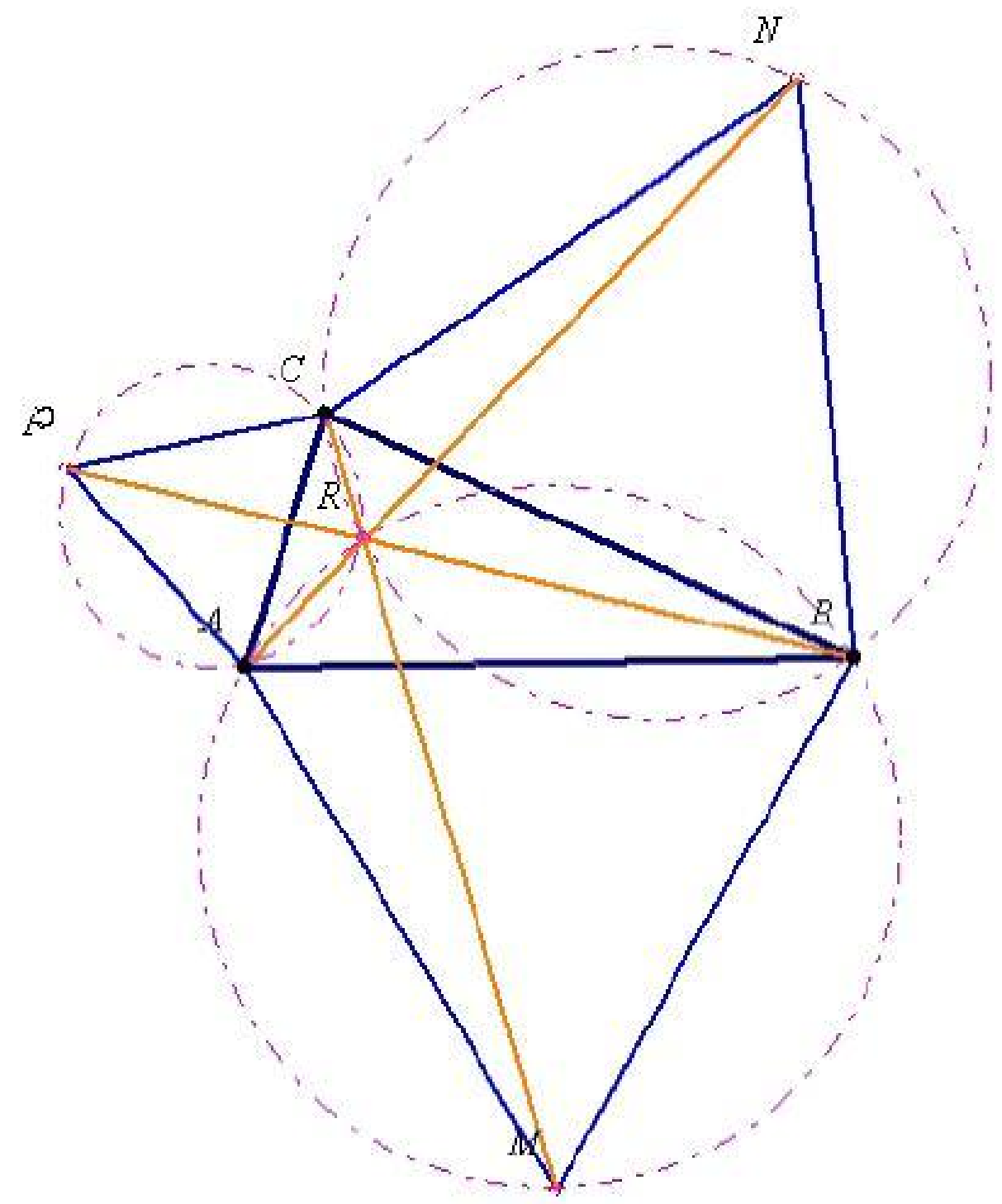

Triangles $\triangle A C M$ and $\triangle A P B$ are congruent, because

$$
A M \cong A B, A C \cong A P, \angle M A C \cong \angle B A P=\alpha+60^{\circ}
$$

this congruency is due to the law Edge-Angle-Edge, hence $M C \cong B P$ and $\angle A P R \cong$ $\angle A C R$, where point $\mathrm{R}$ is the second intersection point of circumcircles of regular triangles $\triangle A C P$ and $\triangle A B M$, hence $A R C P$ is inscribed quadrilateral and $\angle A R C=120^{\circ}$. Also, $A R B M$ is inscribed quadrilateral and $\angle A R B=120^{\circ}$, that's why $\angle C R B=120^{\circ}$.

Similarly, triangles $\triangle A N C$ and $\triangle B P C$ are congruent, thus $A N \cong B P$ and $\angle C N F \cong$ $\angle C B F$, where point $\mathrm{F}$ is the second intersection point of circumcircles of regular triangles $\triangle B C N$ and $\triangle A B M$, hence $B F C N$ is inscribed quadrilateral, thus $\angle C F B=120^{\circ}$, and $F \equiv R$.

\subsubsection{The results of the second exam}

The maximum number of points students can get on the second exam is 20. Points and marks are based on the following classification: 
18-20 points excellent (5)

15-17 points very good (4)

\section{2-14 points good $(3)$}

9-11 points sufficient (2)

0-8 points insufficient (1)

Only 19 students from the first group were present on the day of the second exam.

The results, the dispersion of the points in the tasks of the second exam in the control group are shown in the table below, where tasks are noted vertically in green color, and the points of each task are noted horizontally in red color:

\begin{tabular}{|r||r|r|r|r|r|}
\hline & 0 & 1 & 2 & 3 & 4 \\
\hline \hline 1 & 0 & 0 & 4 & 6 & 9 \\
\hline $2 / \mathrm{a}$ & 0 & 4 & 6 & 9 & \\
\hline $2 / \mathrm{b}$ & 0 & 6 & 13 & & \\
\hline 3 & 0 & 2 & 8 & 4 & 5 \\
\hline 4 & 1 & 8 & 3 & 7 & \\
\hline $5 / \mathrm{a}$ & 1 & 10 & 8 & & \\
\hline $5 / \mathrm{b}$ & 4 & 10 & 5 & & \\
\hline
\end{tabular}

Outstanding students C.Z., K.E. and B.Z. from the control group and G.T., H.M. and J.A. from the experimental group had excellent results, they even answered the special task noted by the star. They were gifted students, participants of mathematical competitions in Serbia and Hungary. They continued their education in universities of mathematics in Novi Sad, Szeged, Budapest.

The results, the dispersion of the points achieved in the tasks of the second exam in the experimental group were:

\begin{tabular}{|r||r|r|r|r|r|}
\hline & 0 & 1 & 2 & 3 & 4 \\
\hline \hline 1 & 0 & 0 & 1 & 4 & 9 \\
\hline $2 / \mathrm{a}$ & 0 & 1 & 9 & 4 & \\
\hline $2 / \mathrm{b}$ & 0 & 0 & 14 & & \\
\hline 3 & 0 & 3 & 2 & 5 & 4 \\
\hline 4 & 0 & 5 & 1 & 8 & \\
\hline $5 / \mathrm{a}$ & 0 & 7 & 7 & & \\
\hline $5 / \mathrm{b}$ & 1 & 9 & 4 & & \\
\hline
\end{tabular}

In the experimental group almost every student started to solve the task, in the control group were students who did not write anything to solve tasks (4) or $(5 / \mathrm{a})$ or $(5 / \mathrm{b})$. There was one student in each group, who was very quiet the entire time during every lesson, an introverted type, but on the exams he/she worked well, getting the average mark. After the exam some students said that they found tasks $(5 / \mathrm{a})$ and $(5 / \mathrm{b})$ boring that is why they did not solve them. Other students with a sufficient mark(2) worked only on the constructions without any proof.

Marks on the exam based on the division given above were: 


\begin{tabular}{|c|c|c|}
\hline & control group & experimental group \\
\hline excellent (5) & 4 & 3 \\
very good (4) & 4 & 6 \\
good (3) & 7 & 4 \\
sufficient (2) & 4 & 1 \\
insufficient (1) & 0 & 0 \\
\hline summary & 19 & 14 \\
\hline average & 3.42 & 3.79 \\
\hline
\end{tabular}

This exam contained classical tasks from planimetry, and these students are gifted in Mathematics, that is why there is no insufficient mark in either group. Both groups worked diligently, accurately and precisely, although the results show that the experimental new group was more successful. The average mark in the old control group was 3.42 but the average mark in the new experimental group was 3.79, which is greater by 10 percent. I think that this difference and the increasing average mark is significant despite the small number of samples of the examined students.

This exam showed giftedness in Mathematics, intellectual vocation, commitment to theoretical mathematics, methodical cognitive perception and developing problem solving thinking, although the students were had only been in our school for three months.

\subsubsection{The results at the end of the school year}

These results show and prove the advantage of the experimental group using visualization, any DGS.

The average grade of the control group is 3.65 .

The average grade of the experimental group is 3.93, which is higher than the previous result by 10 percent.
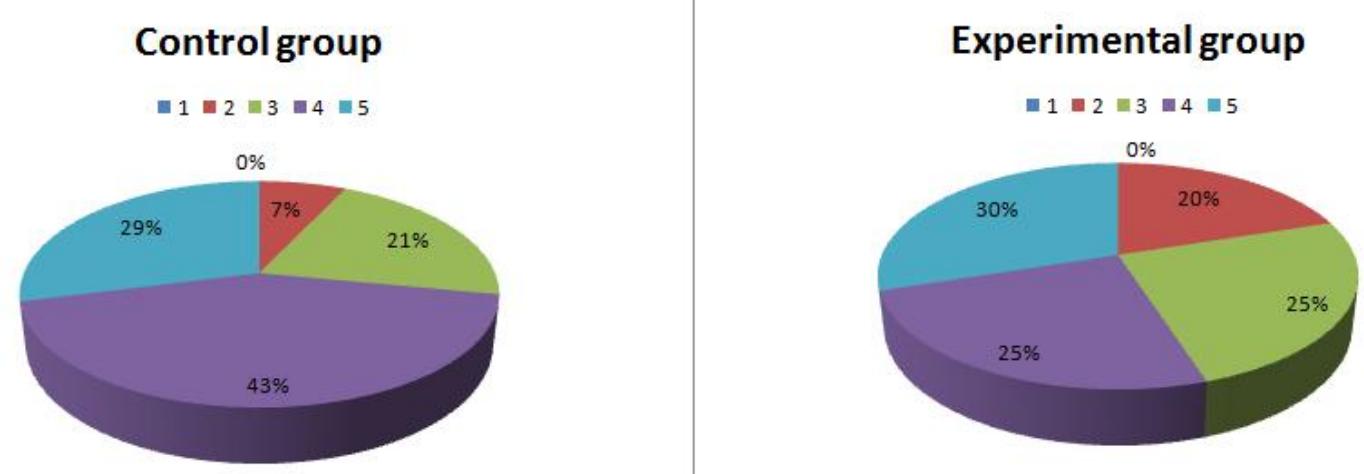

\subsection{Summary}

In the first phase, visualization helped in the exploration of new concepts, their properties, and to find and understand new theorems.

In the second phase, students recalled the accurate construction made on computers by the dynamic geometry system. Their drawings were as accurate as possible. They made an effort to prepare construction as exact as possible using graphite pencil and A4 paper. 
The third phase took place one month later, after the assimilation period. There was an emphasis on theoretical proof.

Characteristics of a proof are:

- The process of mathematical thinking is as important as its mathematical result.

- The acceptance of the theorem's proof is a social process, as understanding the concept is as important as its formal criteria. Teaching geometry uses the principle of spirality, since the important theorems of geometry appear at every level of education, at different levels different methods, representations are present.

It was enough to remind them of Euler's line, and they knew what their task was: how one can get to the line $O H T$ from the given triangle, across the important points of the triangle.

But not all solutions were adequate (to my disappointment). The nicest solutions were different in using geometrical tools, one used isometric transformation, and another used perspective transformation in the proof, and the third student recalling the proof with vectors.

Measuring the mathematical ability on the tests is not always possible because it is not equal with level of knowledge, and sometimes the students' minds are disturbed by various outside factors.

Some students show a lower achievement on tests than their participation during classes would indicate. Other students are never active during the lessons but they work very well during tests (rarely making any mistakes).

It is the teacher's important mission to keep in mind that every student must be supervised individually during visualization work on the computer. It is a good idea to commend students who completed the homework well; as it highlights problems certain students may have with inaccuracy when constructing using pencil and paper. The main point is precision where the constructional tools play a major role, and it also depends on the quality of the graphic/technical pencil, rulers and the compass. After the winter holidays during the revision the teacher must give instructions for students about which problems and proofs and about where students can find them either in their book or notebook. A special level of the cognitive process is the knowledge become a part of the student's subconscious. The teacher's duty is to give enough time for that process of deepening the knowledge but also to revise after a certain time, to ensure the deepening has occurred.

"The teaching and learning of geometry in grammar school is saddled with a conflict. There is a body of (axiomatically built) mathematics to b taught, learned and made that deals with properties of shapes and relations among shapes [25]. If the human mind indeed needs images to help it think about spatial matters, how do we avoid the inevitable specificity that images possess when we are trying to understand the generalities that characterize the objects we are exploring? The central idea of the (Dynamic Geometry System) geometric software is that the user can select or construct a primitive shape,....and make a sequence of Euclidean constructions such as parallels, perpendiculars, angle bisectors, and so forth, on this shape."

In my opinion visualization on computer is a useful tool, there is an increasing development in constructions, in problem-solving thinking and in students' activity during Geometry lessons. Some students are not interested in learning Geometry, but a large portion of the groups are motivated and work with great enthusiasm. I think that it is worthy to help students in the teaching-learning process using computers. 


\section{Geometry II, Trigonometry}

In the students' second of studies at the grammar school there is trigonometry and stereometry in the official plan given by the Ministry of Education of Serbia. There are laws of sines and cosines, proofs of theorems and their practice.

The History of Science can provide tools so that students will be able to achieve scientific concepts successfully. As John Heilbron said in his conference presentation "History as a collaborator of Science" (2003):

"Historical material should have a prominent place in the pedagogy of Science; but not to recall the past for itself, or for anecdotes or sugar coating, but because, for some purposes, History may be the best way to teach Science."

"In fact, the History of Science is a very useful tool to help the comprehension of mathematical ideas and concepts. Also, the History of Science is a very useful tool to help the understanding of Mathematics as a useful, dynamic, humane, interdisciplinary and heuristic science. On the one hand, the History of Science can be used as an implicit resource in the design of a syllabus, to choose context, mathematical problems and auxiliary sources." [14]

Trigonometry is useful in tasks of proving the special and important theorems of geometry. The theorems from Ceva, Menelaus, Ptolemy and Euler's line using trigonometrical tools become an easy but accurate practice with sine and cosine theorems.

\subsection{Menelaus' theorem}

Menelaus of Alexandria (born: about 70 AD, died: about $130 \mathrm{AD}$ ) was one of the later Greek geometers who applied spherical geometry to astronomy, he was the first to recognize geodesics on a curved surface as natural analogs of straight line in plane. 


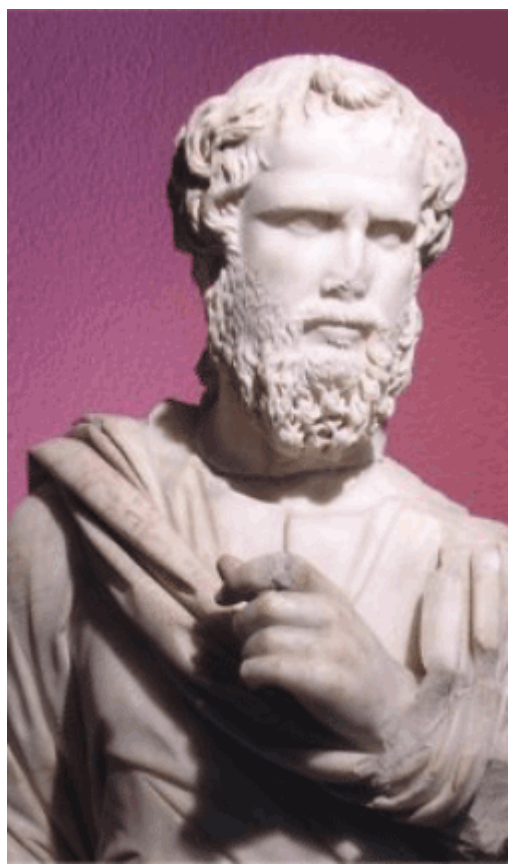

He is best known for the so-called Menelaus' theorem: for triangles in the plane, if points $D, E, F$ that lie on lines $B C, A C, A B$ of the triangle $A B C$ is

$$
A F \cdot B D \cdot C E=F B \cdot D C \cdot E A,
$$

and for spherical triangles,

$\sin A F \cdot \sin B D \cdot \sin C E=\sin F B \cdot \sin D C \cdot \sin E A$.

Teacher (in the role of moderator): Let's experiment! Do you know (remember) Hilbert's system of axioms, especially the fifth axiom of order?

It is "Pasch's Axiom: Let $A, B, C$ be three points not lying in the same straight line and let $l$ be a straight line lying in the plane of the triangle $\triangle A B C$ and not passing through any of the vertices $A, B, C$. Then, if the straight line $l$ passes through a point of the segment $A C$, it will also pass through either a point of the segment $B C$ or a point of the segment $A B . "$

Experiments on computer: But what happens with the third point? Let's draw it in DGS GeoGebra. Let line $l$ have intersection points $D$ and $E$ with segments $B C$ and $A C$, and let line $l$ intersect line $A B$ in the point $F$ out of the triangle $A B C$. Does that point $F$ always exist?

Students knew the answer, that two lines in the same plane can be parallel or intersect, but I asked them to let $F$ be the intersection point, and the option of parallel lines $l$ and $A B$ is to be investigated later.

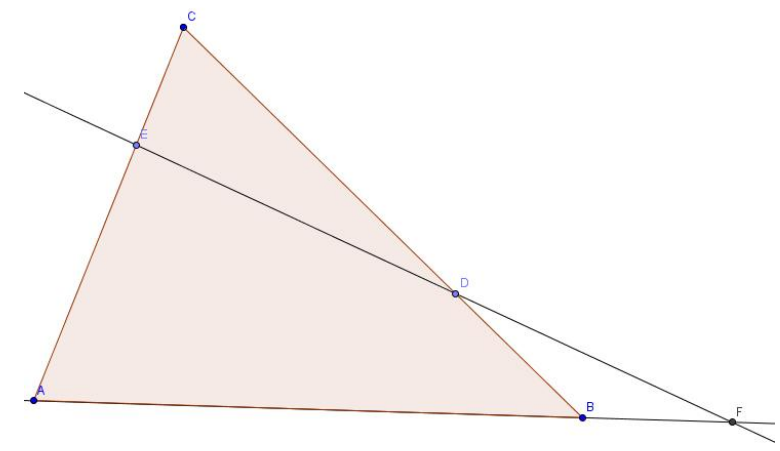

Color the first part of segments $A E, C D, B F$ red, and color the second part $E C, D B, F A$ blue. 


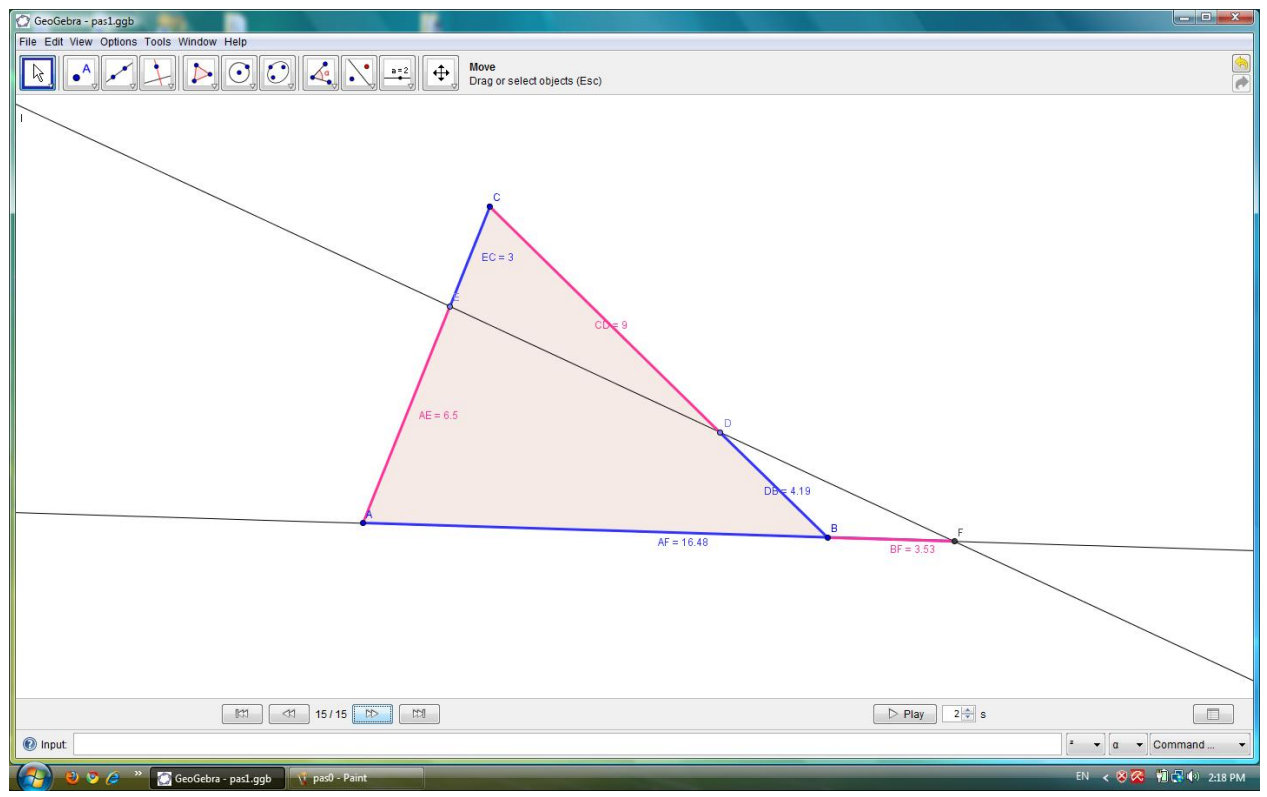

Teacher (in the role of moderator): Now please measure the segments you have on your pictures. Let's count the proportions of the red and blue segments on the each side of the triangle. Find their "good" combination!

\section{Experiences:}

The students' answer is slow, but two or three of them have found it, their product is 1 . Teacher (in the role of moderator): What would happen if these segments had a direction? (as vectors)

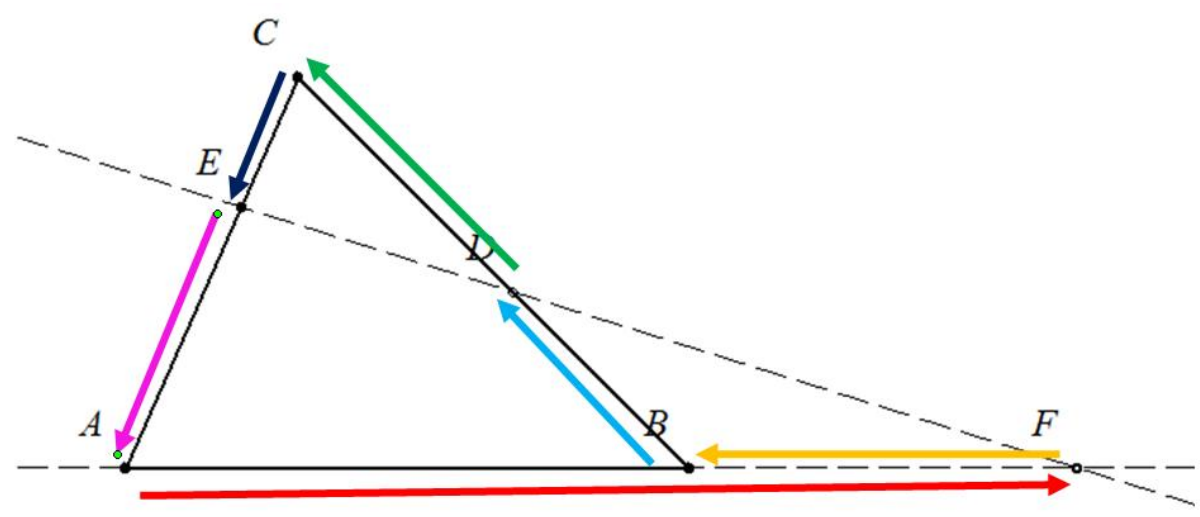

I completed the projected DGS drawing on the white board using six colors, with markers, giving each segment a direction. 


\section{Conjecture:}

The students' answer is fast, their product is -1 , because segments $A F$ and $F B$ have opposite directions.

Teacher (in the role of moderator): What would happen if the lines $l$ and $A B$ were parallel?

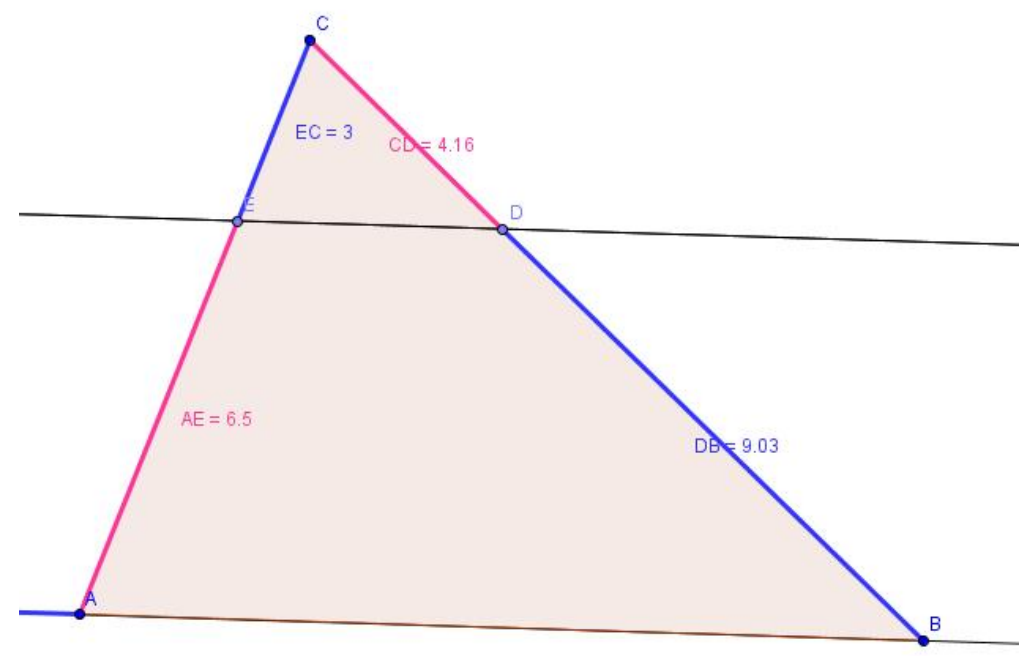

Students usually recognize the ray theorem ( If two rays are intersected by parallels, the intersected parts of the one ray are in the same proportion as those of the other ray), and that's why the proportion of the segments $A E: E C=B D: D C$ is the same. It is the special case.

Teacher: Now formulate the theorem you've found.

\section{Formulation}

Theorem 4.1. (Menelaus of Alexandria)

Given points $A, B, C$ that form triangle $A B C$, and points $D, E, F$ that lie on lines $B C$, $A C, A B$, points $D, E, F$ are collinear if and only if

$$
\frac{\overline{A F}}{\overline{F B}} \cdot \frac{\overline{B D}}{\overline{D C}} \cdot \frac{\overline{C E}}{\overline{E A}}=-1 \text {. }
$$

In the theorem $\overline{A F}$ means that segment $A F$ has got direction from the terminal vertex $A$ to the initial vertex $F$, and similarly to the others, that is why the result is -1 , because the directed segments $\overline{A F}$ and $\overline{F B}$ have opposite directions. 


\section{Deductive proof:}

There is a proof of this theorem in the planimetry using similarity of right angle triangles, which was proved in geometry I.

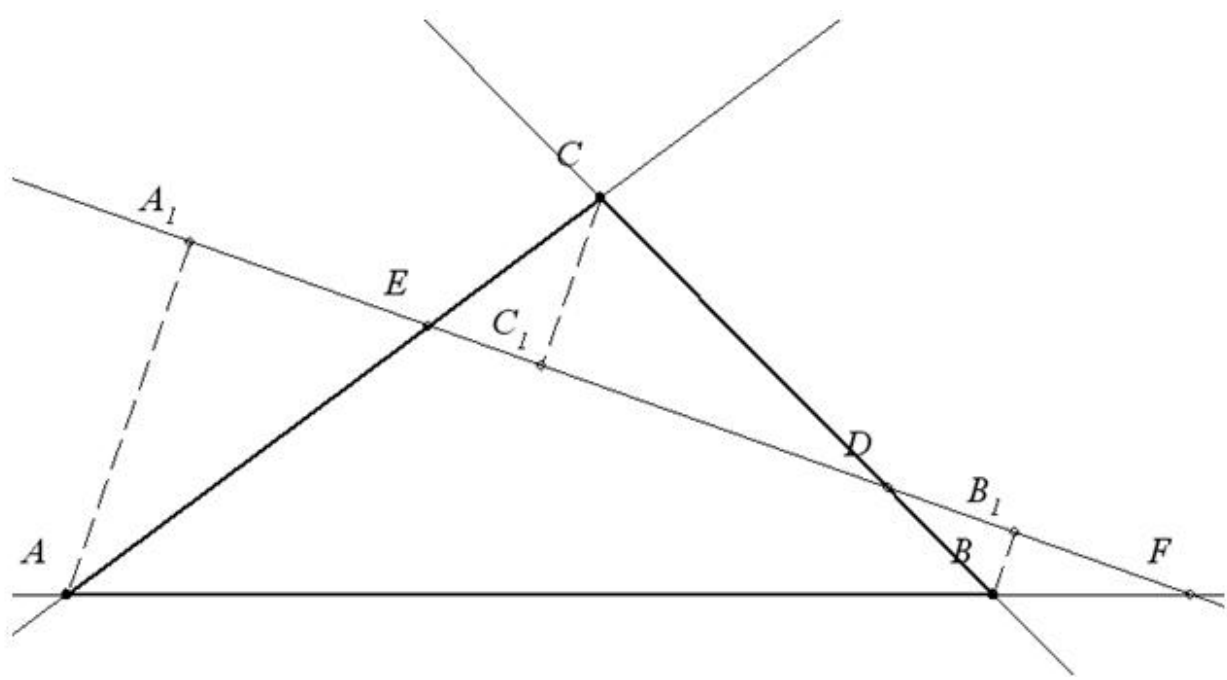

Let points $D, E$ and $F$ be collinear, lie on the line $l$, and let points $A_{1}, B_{1}$ and $C_{1}$ be the normal (orthogonal) projections of the vertices of triangle $A B C$ to the line $l$. Hence

$$
\triangle A A_{1} F \sim \triangle B B_{1} D ; \triangle C C_{1} E \sim \triangle A A_{1} E ; \triangle B B_{1} \sim \triangle C C_{1} D
$$

where the congruency of angles is shown

$$
\angle C E C_{1} \cong \angle A E A_{1} ; \angle C D C_{1} \cong \angle B D B_{1} ; \angle B F B_{1} \cong \angle A F A_{1}
$$

The negative sign came from the pair of opposite vectors, in this example they are $\overline{A F}$ and $\overline{F B}$.

Thus we can use the sine law for the triangles $D B F, D E C, A E F$.

If points $D, E$ and $F$ are collinear, then

$$
\begin{aligned}
& \frac{F B}{B D}=\frac{\sin \angle B D F}{\sin \angle D F B} ; \\
& \frac{D C}{C E}=\frac{\sin \angle C E D}{\sin \angle C D E} ; \\
& \frac{E A}{A F}=\frac{\sin \angle D F A}{\sin \angle F E A} .
\end{aligned}
$$

Multiplying these equalities:

$$
\frac{A F}{F B} \cdot \frac{B D}{D C} \cdot \frac{C E}{E A}=\frac{\sin \angle B D F}{\sin \angle D F B} \cdot \frac{\sin \angle C E D}{\sin \angle C D E} \cdot \frac{\sin \angle D F A}{\sin \angle F E A}=1
$$

because angles $\angle B D F, \angle C D E$ are opposite angles, their sine values are equal, as supplementary angles.

This is an image created by P.A. using visualization DGS GeoGebra, without an algebra window, only using geometry construction, no axis, no grid-lines. It is very similar to drawings in DGS Euklides students learn and use in first grade. I think that it is adequate procedure to first use of software GeoGebra and its introduction should be led step by step, although students are familiar with Dynamic Geometry Systems. 


\section{ge GeoGebra - Piri Annamari.ggb}

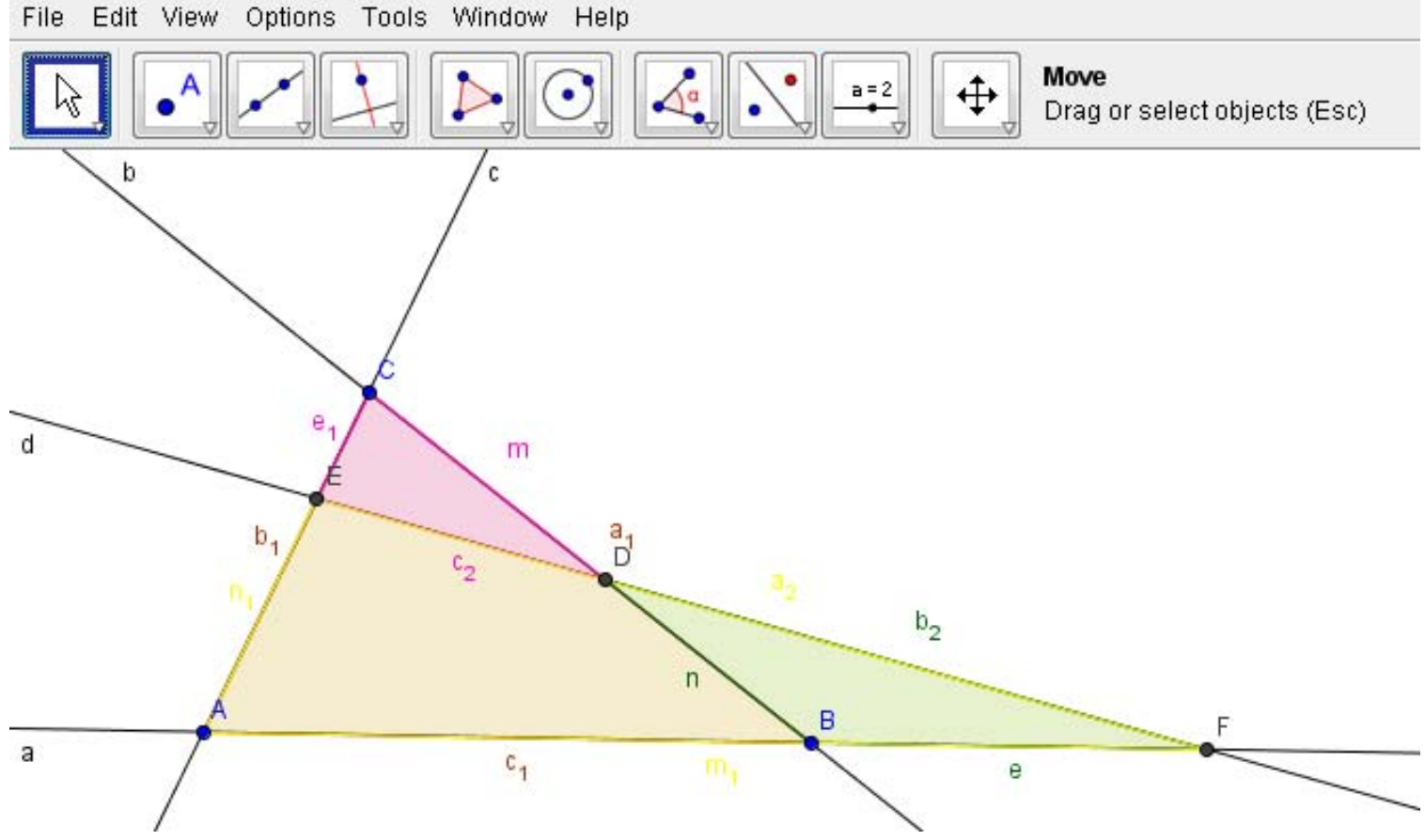

In DGS GeoGebra possibility to count the value of formula

$$
f=\frac{A F}{F B} \cdot \frac{B D}{D C} \cdot \frac{C E}{E A}
$$

exist if points $D, E$ and $F$ lie on lines $B C, A C$ and $A B$, respectively. However, the value of formula $f$ is equal to 1 if points $D, E$ and $F$ are collinear.

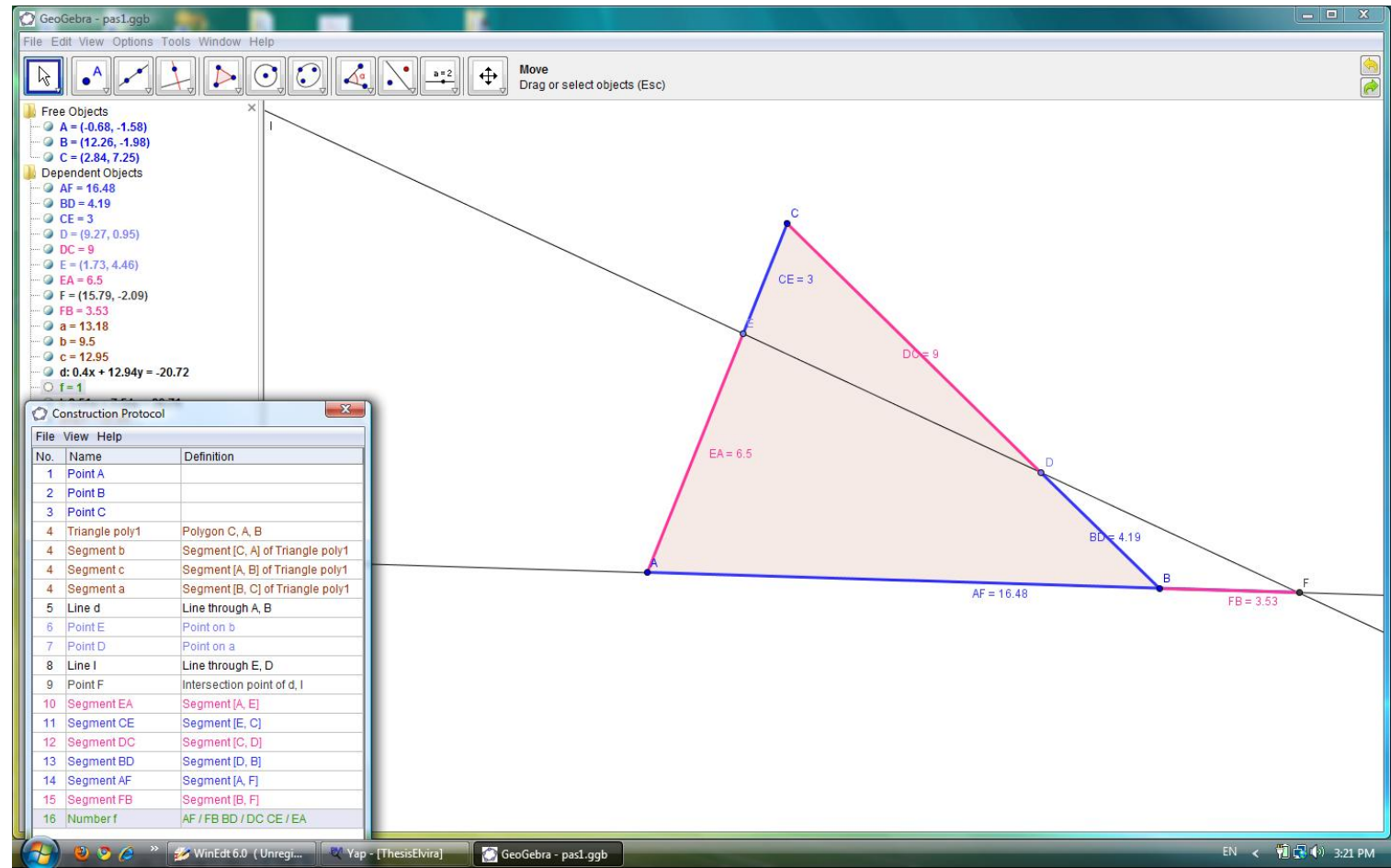




\section{The opposite direction:}

Two questions appear here from the teacher, who is the moderator of the lesson:

1. Try to move point $F$ on the line $A B$.

2. How does the value of formula $f$ change during the movement of point $F$ ?

This is a great chance to experiment and follow the value of formula $f$. Every student is able to create this image and with a wonderful expectation they follow the changing value of $f$ (it is in the shadow in the algebra window on the left side of the picture).

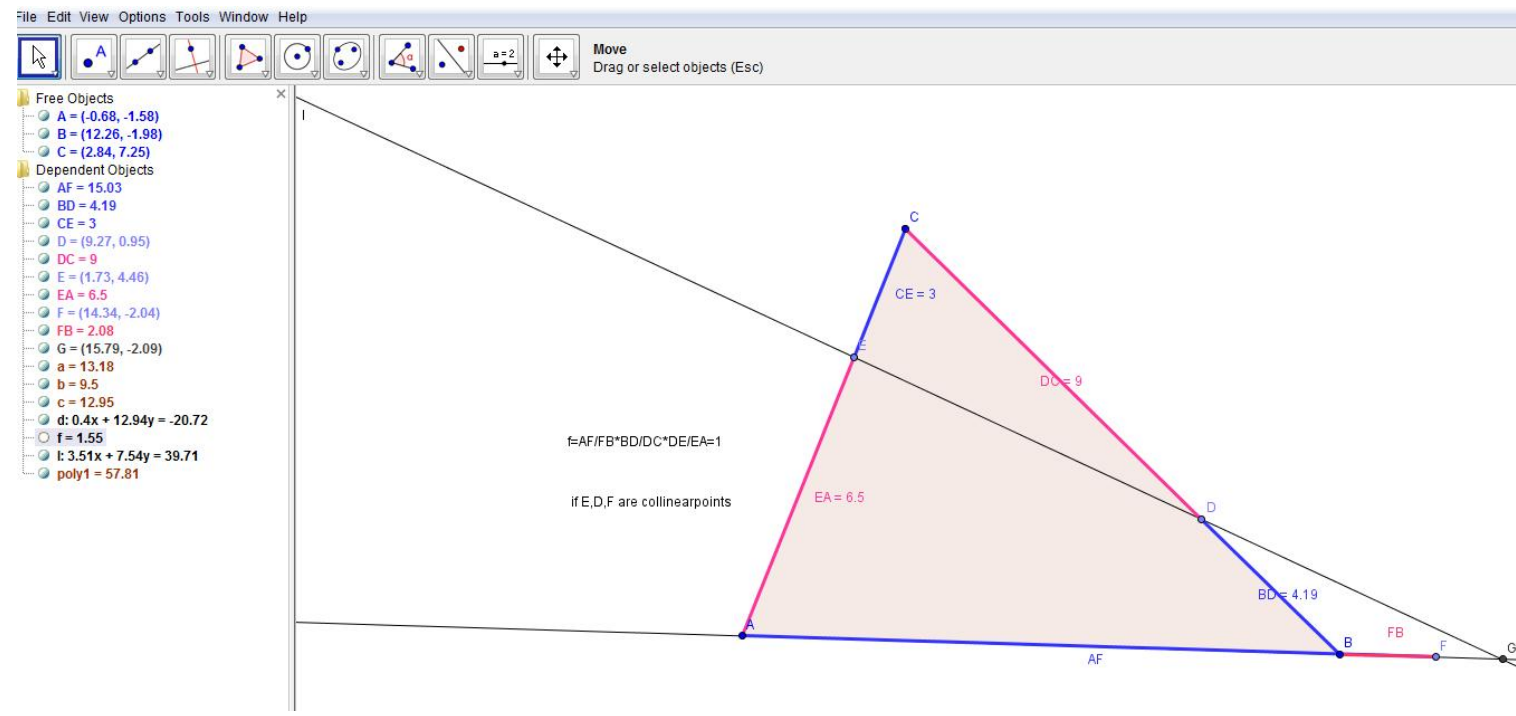

The results from these experiments is that from the opposite condition we get the opposite statement, if points $D, E$ and $F$ are not collinear, than the value of formula $f$ is not equal to 1. 


\subsection{Ceva's theorem}

Giovanni Ceva (born: 7 Dec 1647 in Milan, died: 15 June 1734 in Mantua) was an Italian mathematician, physicist, and hydraulic engineer best known for the geometric theorem bearing his name concerning straight lines that intersect at a common point when drawn through the vertices of a triangle, "De lineis rectis", 1678. He was educated in a Jesuit college in Milan, then studied at the University of Pisa, where he subsequently became a professor. In 1686, however, he was designated as the Professor of Mathematics at the University of Mantua and worked there for the rest of his life.

Teacher: The next examination includes finding the product of the proportion of the segments $A E, E C, C D, D B, B F, F A$ if segments $A D, B E, C F$ intersect at one common point $S$ inside the triangle $\triangle A B C$.

The students' images are very well constructed, similarly to the previous experiments. They have found the connection very fast, and formulated their conjectures.

\section{Theorem 4.2. (Giovanni Ceva)}

Given a triangle $A B C$, and points $D, E$, and $F$ that lie on lines $B C, C A$ and $A B$ respectively, than lines $A D, B E$ and $C F$ are concurrent if and only if

$$
\frac{A F}{F B} \cdot \frac{B D}{D C} \cdot \frac{C E}{E A}=1
$$

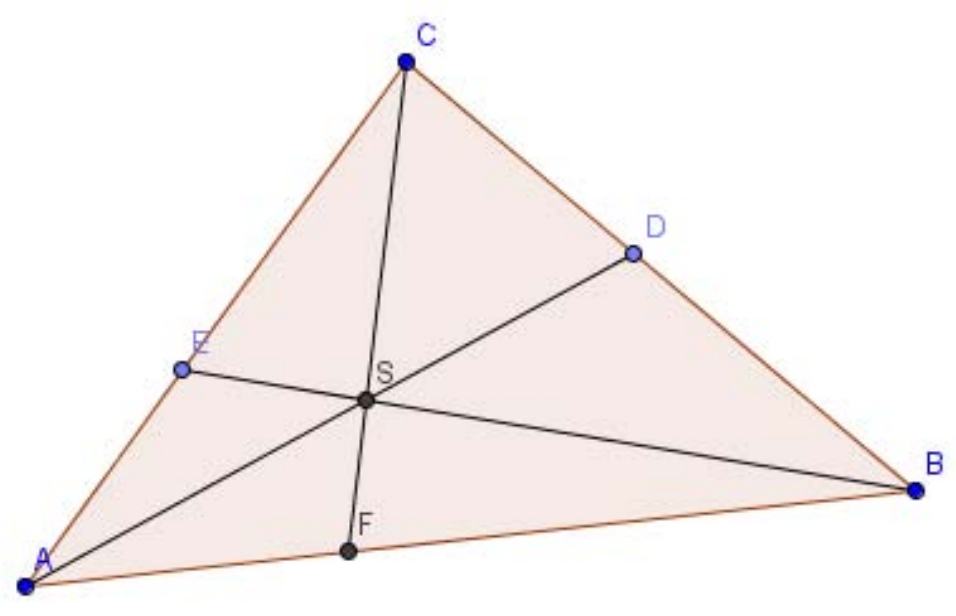

Lines $A D, B E, C F$ divide triangle ABC to six triangles $\triangle A S F, \triangle B S F, \triangle B S D, \triangle C S D$, $\triangle C S E, \triangle A S E$. Using the sine law on these triangles:

$$
\begin{aligned}
& \frac{A F}{\sin \angle A S F}=\frac{A S}{\sin \angle A F S} ; \frac{B S}{\sin \angle B F S}=\frac{B F}{\sin \angle B S F} ; \frac{B D}{\sin \angle B S D}=\frac{B S}{\sin \angle B D S} ; \\
& \frac{C S}{\sin \angle C D S}=\frac{C D}{\sin \angle C S D} ; \frac{C E}{\sin \angle C S E}=\frac{C S}{\sin \angle C E S} ; \frac{A E}{\sin \angle A S E}=\frac{A S}{\sin \angle A E S} .
\end{aligned}
$$

From the congruency of angles $\angle A S E \cong \angle B S D, \angle A S F \cong \angle C S D, \angle F S D \cong \angle C S E$, and the equality of the sine of the angle and its supplementary angle. ( $\sin \angle C D S=\sin \angle B D S$, 
$\sin \angle A F S=\sin \angle B F S, \sin \angle C E S=\sin \angle A E S$.

Multiplying these equalities:

$$
\frac{A F}{F B} \cdot \frac{B D}{D C} \cdot \frac{C E}{E A}=\frac{\frac{A S \cdot \sin \angle A S F}{\sin \angle A F S}}{\frac{B S \cdot \sin \angle B S F}{\sin \angle B F S}} \cdot \frac{\frac{B S \cdot \sin \angle B S D}{\sin \angle B D S}}{\frac{C S \cdot \sin \angle C S D}{\sin \angle C D S}} \cdot \frac{\frac{C S \cdot \sin \angle C S E}{\sin \angle C E S}}{\frac{A S \cdot \sin \angle A S E}{\sin \angle A E S}}=1 .
$$

Experimenting in DGS GeoGebra calculating the value of formula

$$
f=\frac{A F}{F B} \cdot \frac{B D}{D C} \cdot \frac{C E}{E A}
$$

students can follow how it changes while point $F$ (or point $E$ or point $D$ ) moves on the sides of triangle $A B C$. The conclusion is:

- if $F \neq G$, but point $F$ is on the line $A B$, then the value of formula $f \neq 1$.
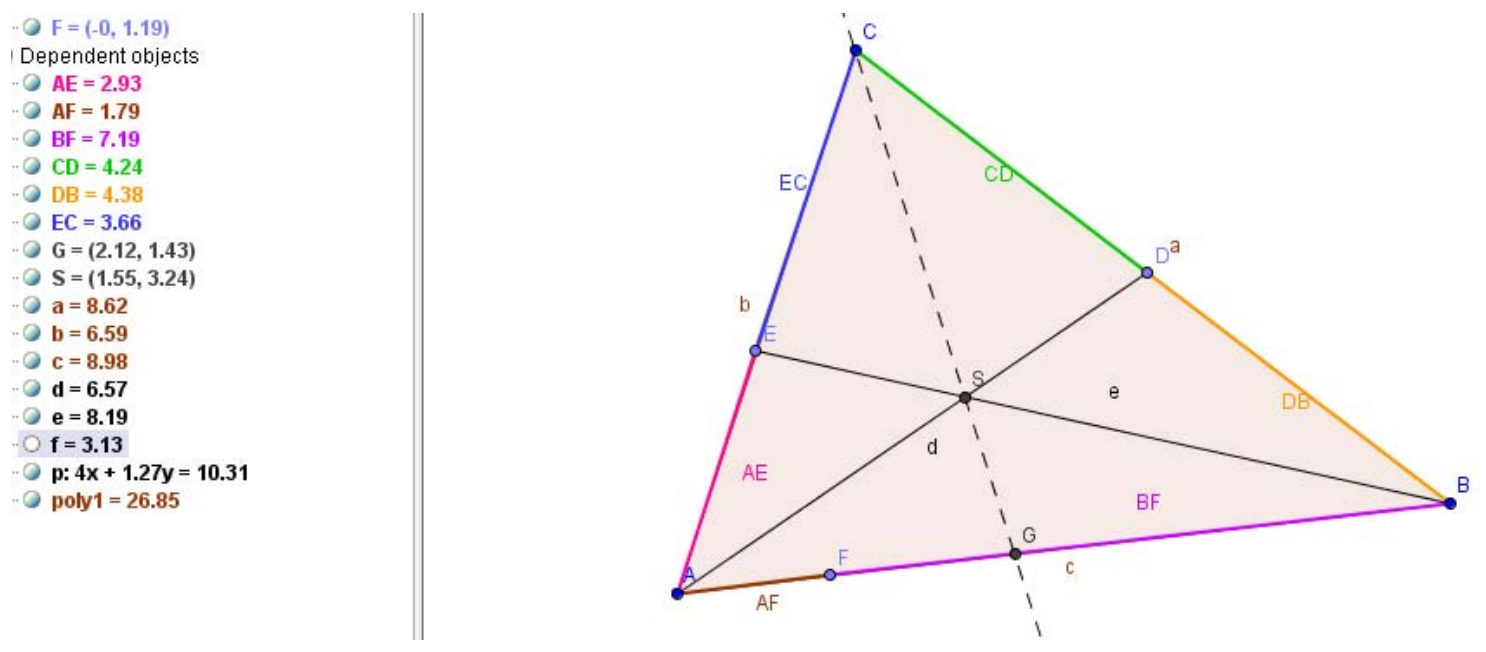

- if $F=G$, point $F$ was moved to the point of intersection of lines $C S$ and $A B$, then $f=1$.

$F=(2.12,1.43)$
Dependent objects
$A E=2.93$
$A F=3.92$
$B F=5.06$
$C D=4.24$
$D B=4.38$
$E C=3.66$
$\mathrm{G}=(2.12,1.43)$
$\mathbf{S}=(\mathbf{1 . 5 5}, 3.24)$
$\mathbf{a}=\mathbf{8 . 6 2}$
$\mathbf{b}=\mathbf{6 . 5 9}$
$\mathbf{c}=\mathbf{8 . 9 8}$
$\mathbf{d}=\mathbf{6 . 5 7}$
$\mathbf{e}=\mathbf{8 . 1 9}$
$\mathbf{f}=\mathbf{1}$
$\mathbf{p : ~} \mathbf{4 x}+\mathbf{1 . 2 7 y}=\mathbf{1 0 . 3 1}$
$\mathbf{p o l y} \mathbf{1}=\mathbf{2 6 . 8 5}$

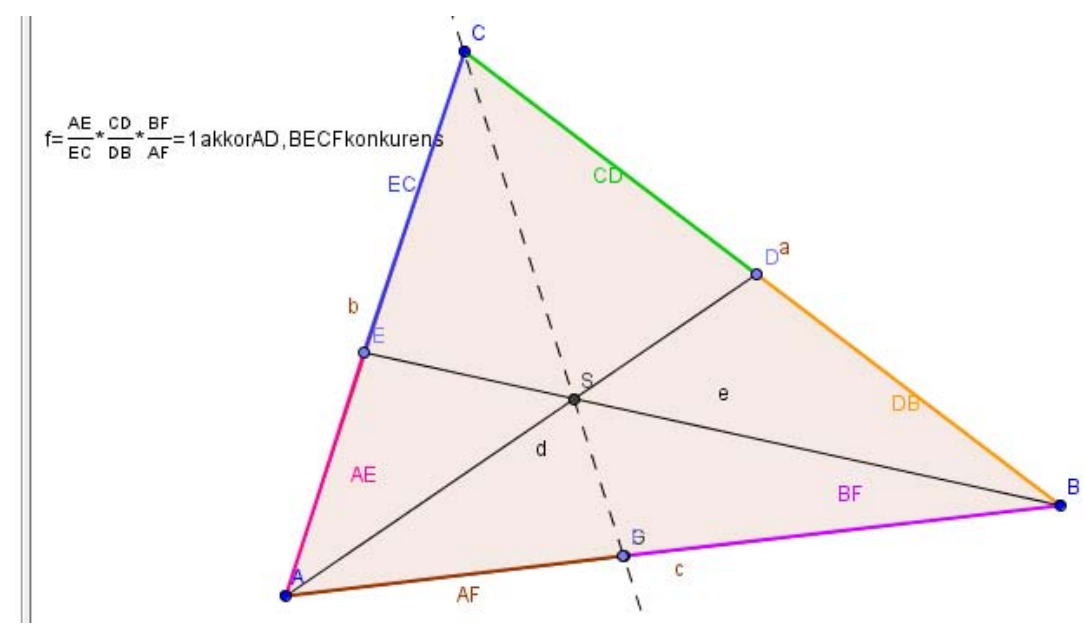


Now students are able to list some well-known and familiar points of the triangle, which are Ceva-points, as well: the orthocenter, the barycenter (centroid), the center of the inscribed circle, the Jordan-point $(D, E$ and $F$ are touching points of the inscribed circle and the sides of the triangle). The following image was created by K.T.:

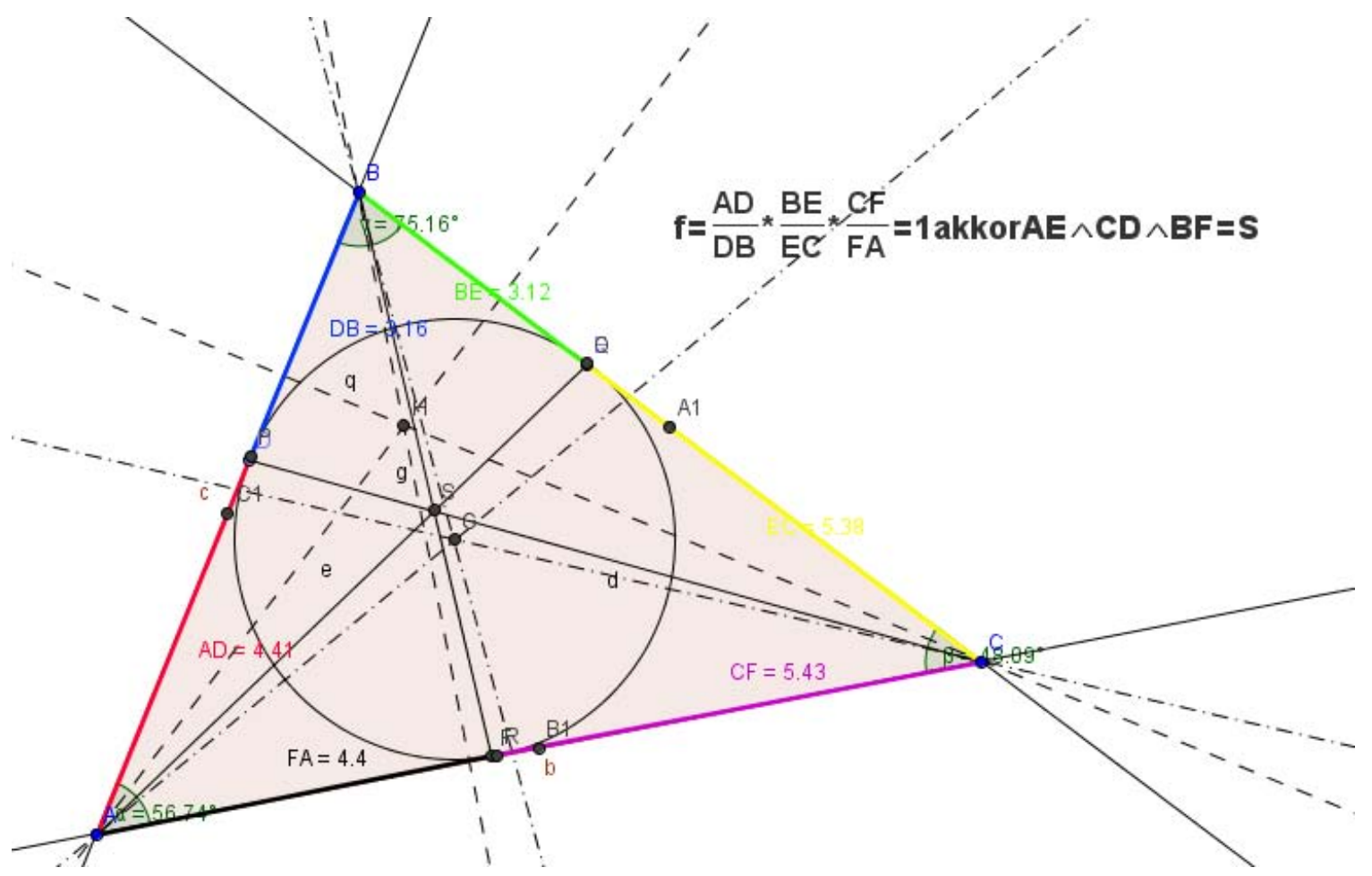

This is a complicated image, but students have drawn it and they can move points $D, E$ and $F$ to the important points of the triangle $\triangle A B C$. The author of this picture noted points with different labels, but he changed the formulation of the statement based on his labels successfully. This abstraction shows that the student used his cognitive knowledge, changed on the basic patterns. 


\subsection{Ptolemy's theorem}

Claudius Ptolemy (born: about 90 AD, died: about 168 AD, Alexandria), was a Roman citizen of Egypt who wrote in Greek. He was a mathematician, astronomer, geographer, astrologer, and poet. He lived in Egypt under Roman rule. He propounded the geocentric theory in the "Almagest" that prevailed for 1400 years. Its original Greek title translates as The Mathematical Compilation, which is a treatise in thirteen books.

Schema huius præmiffx diuifionis Sphxrarum.
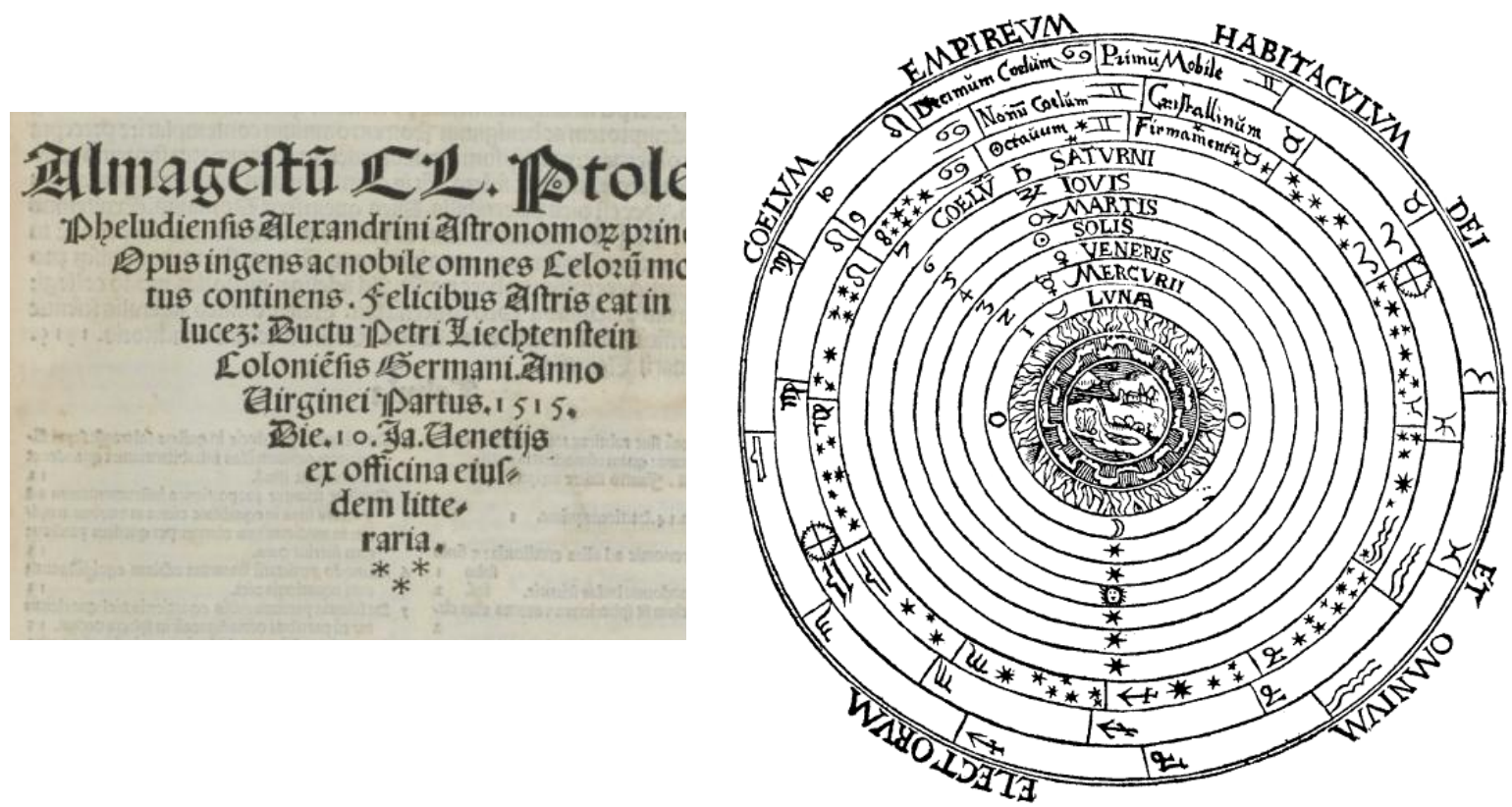

\section{Experiments on the computer:}

Teacher: Let's draw a special quadrilateral inscribed in the circle. Measure its sides and diagonals. What can you see? Is there some connection with these segments and values?

\section{Experiences:}

The students needed five/six minutes and required some leading questions to calculate and to gain experience, and at last to find the demanded formula. It was not an easy task.

Teacher: Find the values of the formulas

$$
f_{1}=A C \cdot B D, f^{\prime}=A B \cdot C D, f^{\prime \prime}=B C \cdot A D .
$$

What can you see now?

\section{Conjecture an formulation:}

Theorem 4.3. (Ptolemy of Alexandria)

Let a convex quadrilateral $A B C D$ be inscribed in a circle, then the sum of the products of the two pairs of opposite sides equals the product of its two diagonals. In other words: $A B \cdot C D+A D \cdot B C=A C \cdot B D$.

There is a demonstration on the webpage [37] explored by the students, but I think that it is better for them to draw a their own pictures themselves, to measure the length of the segments, the sides and diagonals, to calculate the products and the sum of the segments, to check equality using their drawings. 

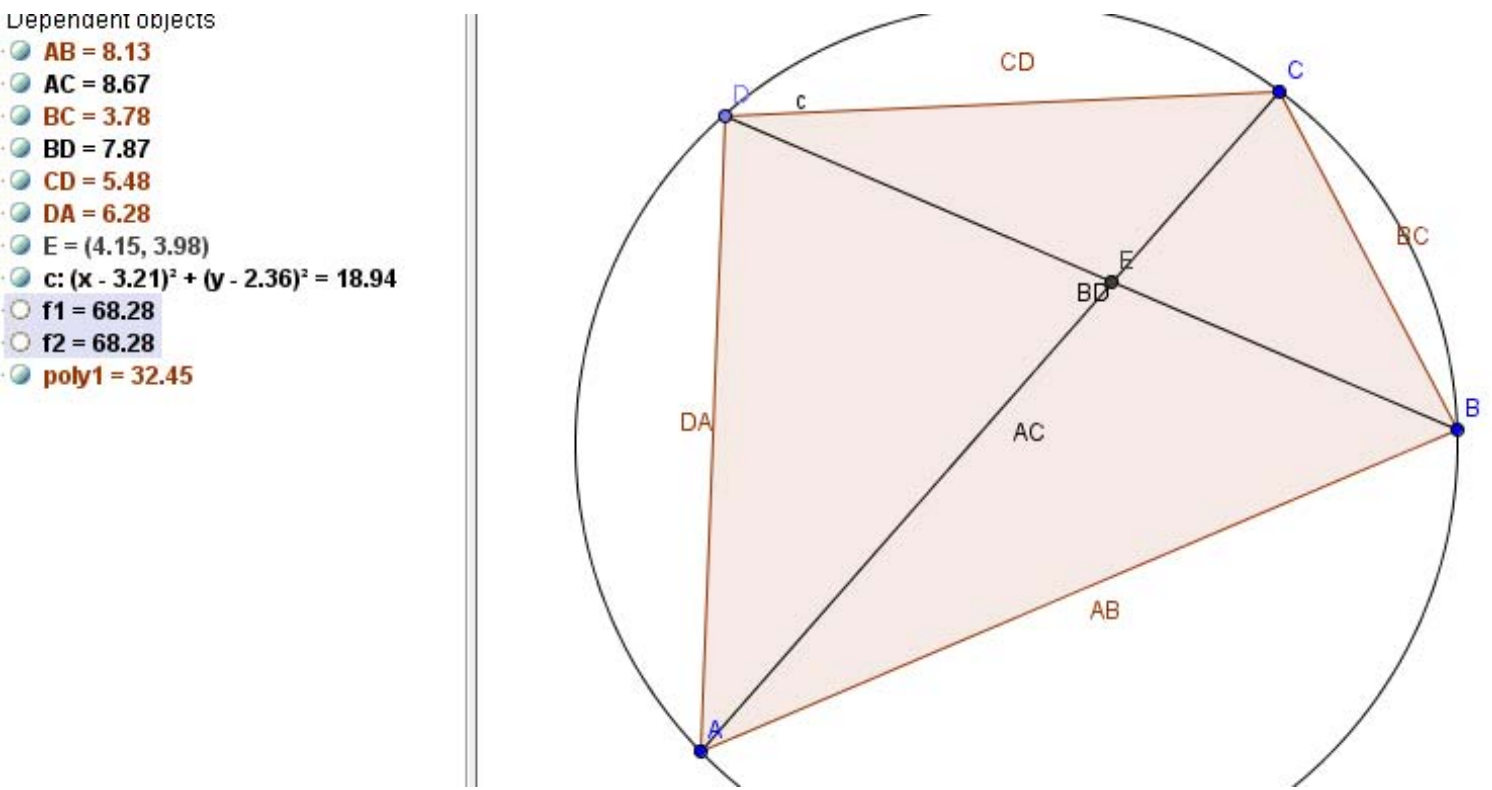

This picture was drawn by R.A., one can follow that $f_{1}=A C \cdot B D$ is always equal to $f_{2}=A B \cdot C D+A D \cdot B C$, if $A B C D$ is an inscribed convex quadrilateral.

The picture was projected to the whiteboard, (which is a very useful tool: if the demonstrator needs to denote or remark some more elements on the picture, a new picture is not required, just use a different colored marker.)

\section{Deductive proof:}

After the visualization here is the student's proof using the cosine theorem (it was written on the whiteboard, with a little help from the teacher):

$$
\begin{aligned}
& B D^{2}=A B^{2}+D A^{2}-2 A B \cdot D A \cdot \cos \angle D A B \\
& B D^{2}=B C^{2}+C D^{2}-2 B C \cdot C D \cdot \cos \angle D C B
\end{aligned}
$$

The conversation between the teacher and the student

Teacher: What do you want to get at the end?

Student: I am expecting the opposite coefficients by $\cos \angle D A B$.

Teacher: How can you reach it?

Student: Multiplying the first equation with $B C \cdot C D$, and the second equation with $A B \cdot D A$.

therefore

$$
B D^{2} \cdot(B C \cdot C D+A B \cdot D A)=B C \cdot C D \cdot\left(A B^{2}+D A^{2}\right)+A B \cdot D A \cdot\left(B C^{2}+C D^{2}\right)
$$

or

$$
B D^{2}=\frac{(A B \cdot B C+C D \cdot D A) \cdot(A B \cdot C D+B C \cdot D A)}{B C \cdot C D+A B \cdot D A} .
$$


Also for the other diagonal

$$
A C^{2}=\frac{(B C \cdot C A+A B \cdot D A) \cdot(A B \cdot C D+B C \cdot D A)}{A B \cdot B C+C D \cdot D A} .
$$

Multiplying these equalities, there is

$$
A C^{2} \cdot B D^{2}=(A B \cdot C D+B C \cdot D A)^{2}
$$

and at the end, Ptolemy's theorem:

$$
A B \cdot C D+A D \cdot B C=A C \cdot B D
$$

The opposite of its statement is also true, which is the result of experimentations from the opposite conditions: In a quadrilateral, if the sum of the products of its two pairs of opposite sides is equal to the product of its diagonals, then the quadrilateral can be inscribed in a circle.

\section{Summary}

The mathematical and problem solving thinking has some steps:

1. The student must have his or her own aim in the work.

2. Student must remember the relevant theorems and laws which are connected to the given problem.

3. The main contents of the lesson aren't given at the beginning; they must be discovered during some practical problems.

The visualization I made for teaching Geometry help on every level of education.

Students like visualizations; they work alone on computers and write answers and proofs to given problems. However during every lesson of geometry differential education in present, which means the lesson plan must be made up of a range of activities from easy tasks to complicated problems. While some students are still working out the basic tasks, some other students think about the solution to complicated problems.

These facts reflect the four dimensions of teaching geometry: the scientific, pedagogical, psychological and constructional dimensions. The teacher must give enough space and possibility for the student's creative work. 


\section{Geometry III, Linear algebra and analytical ge- ometry}

The plan of the third grade given by the Ministry of Education of Serbia contains analytical geometry, to describe a plane using Descartes' coordinates and the equations of lines, circles, ellipses, hyperbolas and parabolas.

Visualization on the computer of the curves of second order helps students understand theory and make their own models in their notebooks with graph paper. The next useful Dynamic Geometry System is "GeoGebra". It is not unknown for the students of the third grade, because they had experienced it in the second grade, but without algebraic forms, and at this point algebraic model appears. Students are familiar with basic geometry constructions, important theorems of axiomatically built Euclidean and non-Euclidean geometry.

Now it is time to observe the algebra window. There are tasks to find and prove the above-mentioned theorems. GeoGebra is very useful for visualization, but to prove in a general analytical form it is possible to use the software Mathematica 6.2. First of all, there are exercises for the linear function, the line and its points.

\subsection{Euler's line}

The well-known task, Euler's line is a good task here, too. For the given three points A, $\mathrm{B}$ and $\mathrm{C}$ find the equation of the sides of the triangle, and the important points of the triangle $(H, O, T)$ and finally the equation of Euler's line. Check Euler's theorem:

$$
\overrightarrow{H T}=2 \cdot \overrightarrow{T O}
$$

To solve this problem there are several subtasks to be worked out:

1. the equations of the lines $A B, B C$ and $A C$;

2. the altitudes and the orthocenter of the triangle;

3. the medians and the barycenter;

4. the perpendicular bisectors and the circumcenter

5. the equation of the line $H O$ (or $H T$ or $O T$ ) and the verification of whether the third point belongs to that line;

6. the coordinates of vectors $\overrightarrow{H T}$ and $\overrightarrow{T O}$;

7. checking the ratio of vectors $\overrightarrow{H T}$ and $\overrightarrow{T O}$. 
We spent two lessons in the computer laboratory to create visualization on DGS, and to draw in notebooks, to learn the basic steps of the task. DGS helped to find the equations and the intersection points. These tasks were done on some special triangles with given coordinates of vertices or the given equation of the lines in the coordinate system. Here is a picture made on the computer (the three lines of the sides of the triangle are given):

$$
\begin{gathered}
A B: 3 x-2 y+1=0, \\
B C: 3 x+y+4=0, \\
C A: 3 x-5 y+34=0 .
\end{gathered}
$$

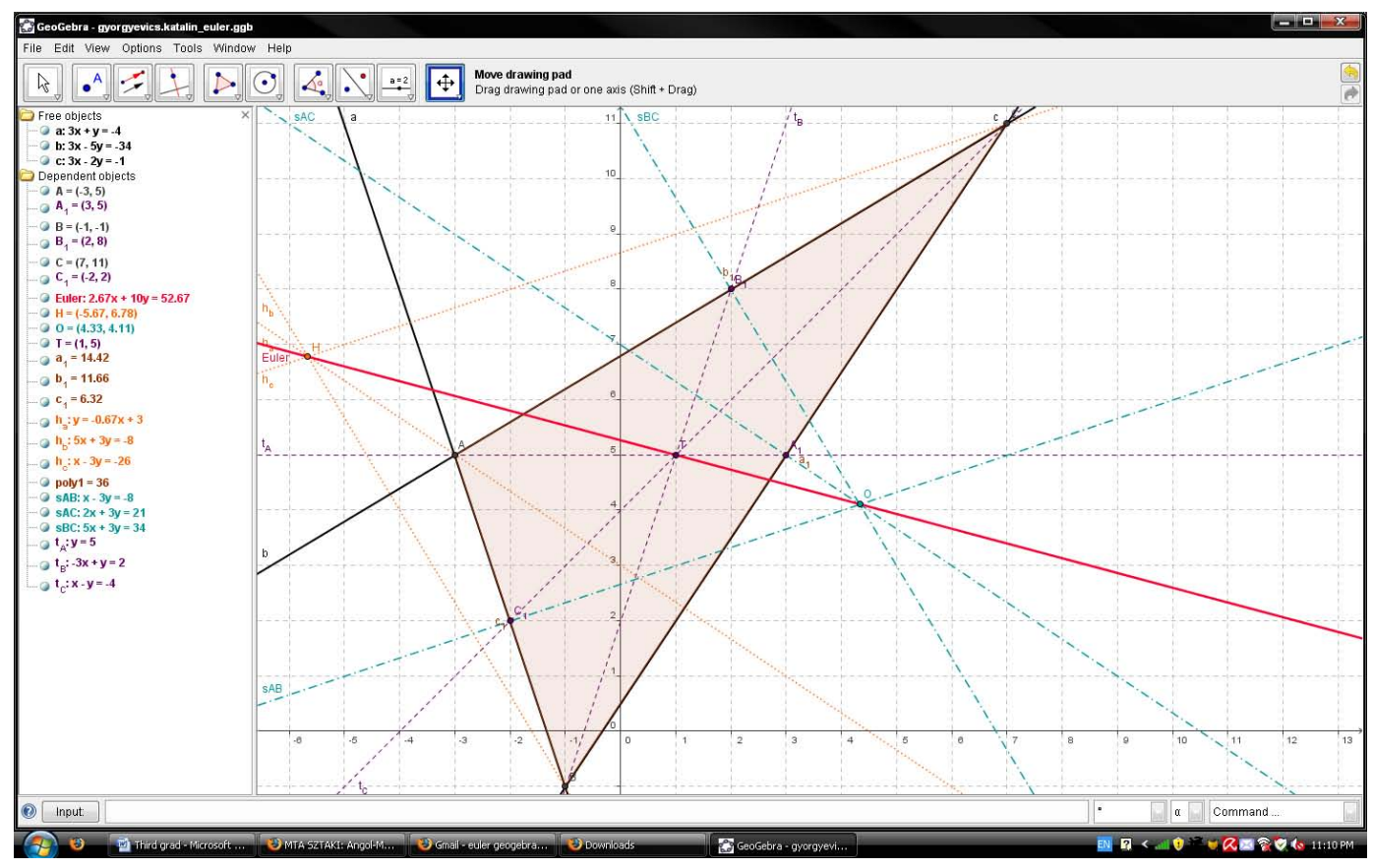

\section{Test for assessment}

After a few practice lessons with and without computers in the computer laboratory the test for assessment was done without using computers. Students had to draw visualization on graph paper $A 4$. The coordinates of the given triangle $\triangle A B C$ were $A(3,5), B(6,2)$ and $C(-2,-1)$.

The required results are:

The equation of the lines of the edges of the triangle $\triangle A B C$

$$
\begin{gathered}
A B: x+y-8=0, \\
A C: 6 x-5 y+7=0, \\
B C: 3 x-8 y-2=0 .
\end{gathered}
$$

The equations of the altitudes of the triangle $\triangle A B C$

$$
\begin{gathered}
h_{a}: 8 x+3 y-39=0, \\
h_{b}: 5 x+6 y-42=0, \\
h_{c}: x-y+1=0 .
\end{gathered}
$$


The coordinates of the orthocenter as the intersection of the altitudes are

$$
H\left(\frac{36}{11}, \frac{47}{11}\right) \text {. }
$$

The equations of the symmetry lines of the triangle $\triangle A B C$

$$
\begin{gathered}
s_{A B}: x-y-1=0, \\
s_{B C}: 8 x+3 y-\frac{32}{2}=0, \\
s_{A C}: 5 x+6 y-\frac{29}{2}=0 .
\end{gathered}
$$

The coordinates of the circumcenter are

$$
O\left(\frac{41}{22}, \frac{19}{22}\right) \text {. }
$$

The coordinates of the barycenter are

$$
T\left(\frac{7}{3}, 2\right) \text {. }
$$

The equation of the Euler's line of the triangle $\triangle A B C$ is

$$
75 x-31 y-113=0 .
$$

The GeoGebra-image is below:

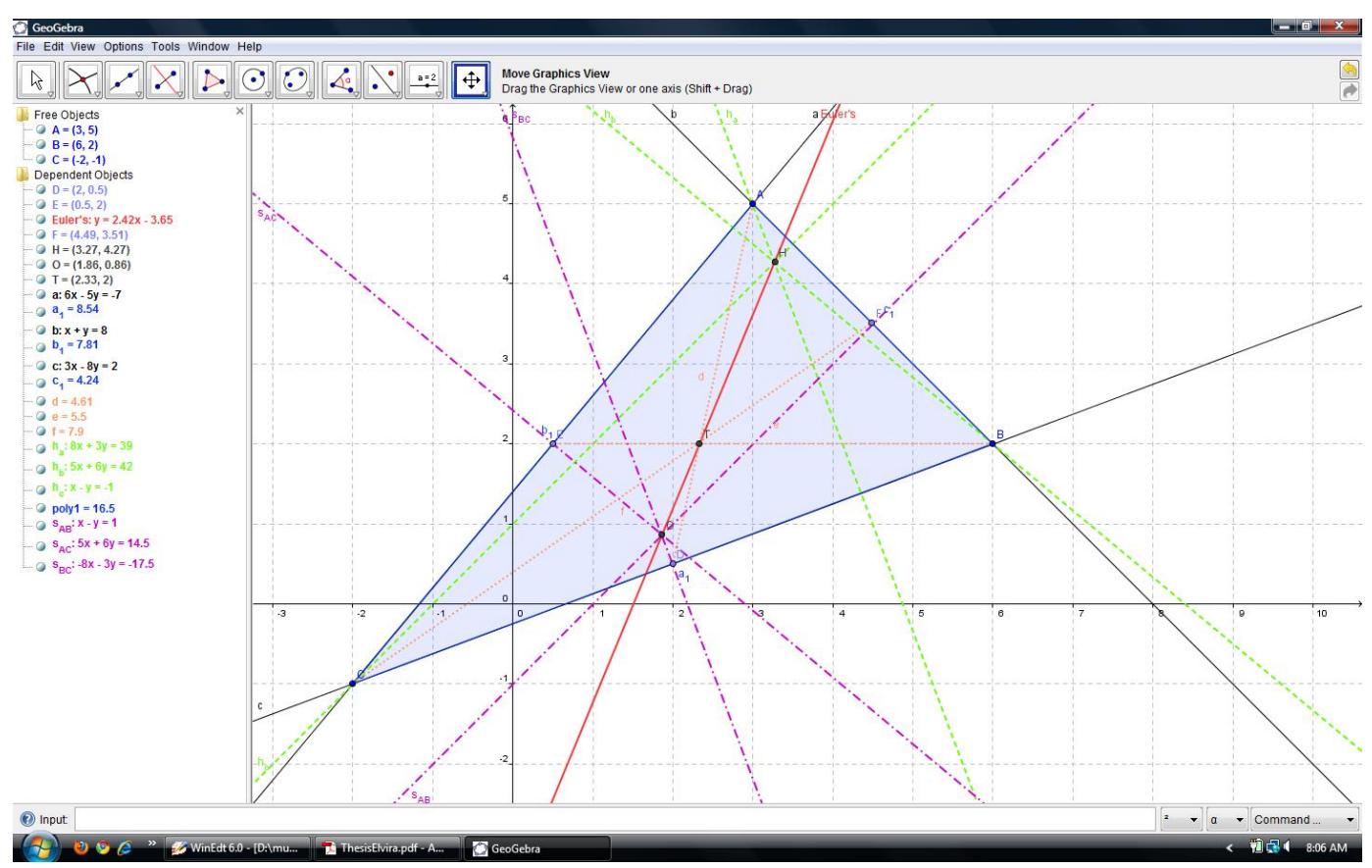


Here are some images of their work:

- M.K. did not use a ruler, but his picture is very well done, precisely enough constructed, the results are good.

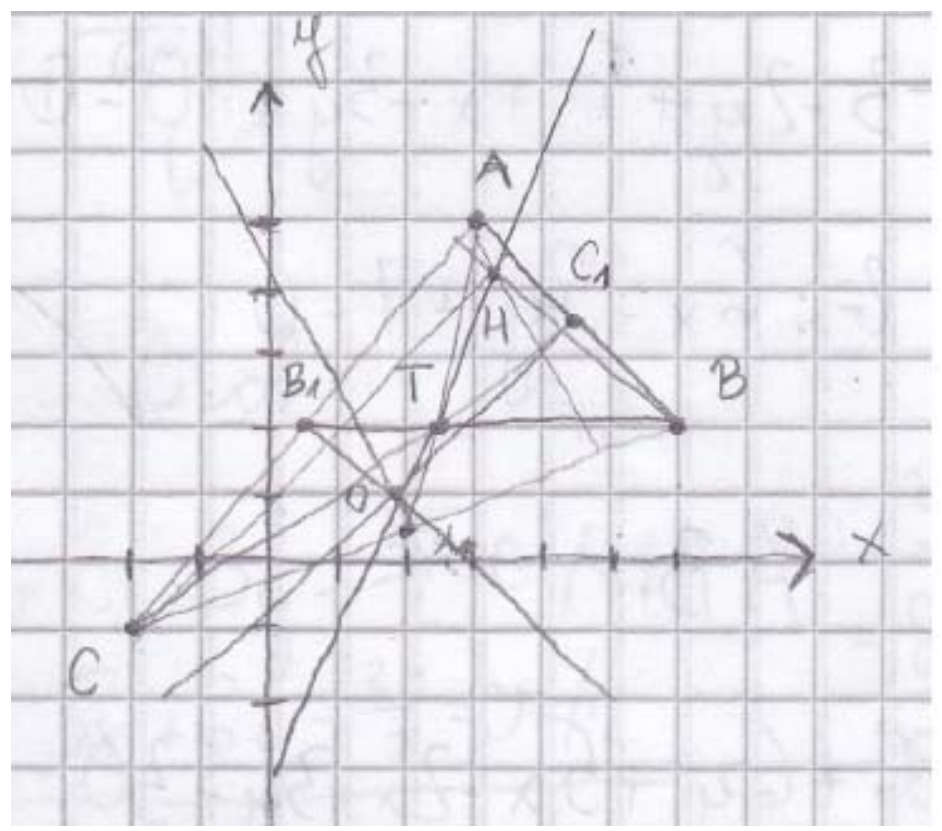

- V.A. did not need every line, she marked the imported points only, but it is a very nice image, precisely constructed. Euler's line is emphasized with a different color, yellow. She's a very smart and conscientious, an excellent student.

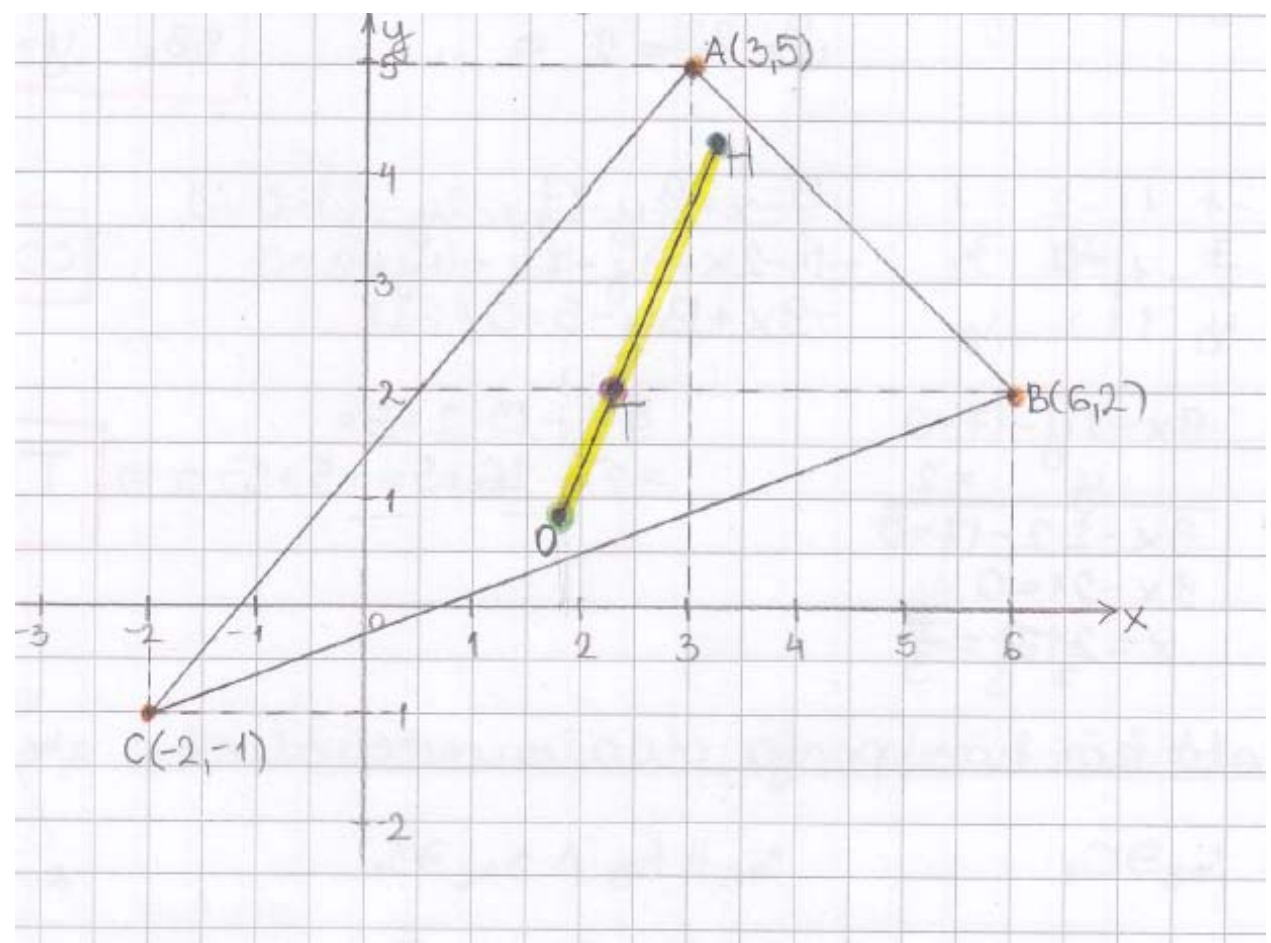


- A.T. drew an almost precise picture, every point is noted, but there Euler's line was not present. The calculation results were good.

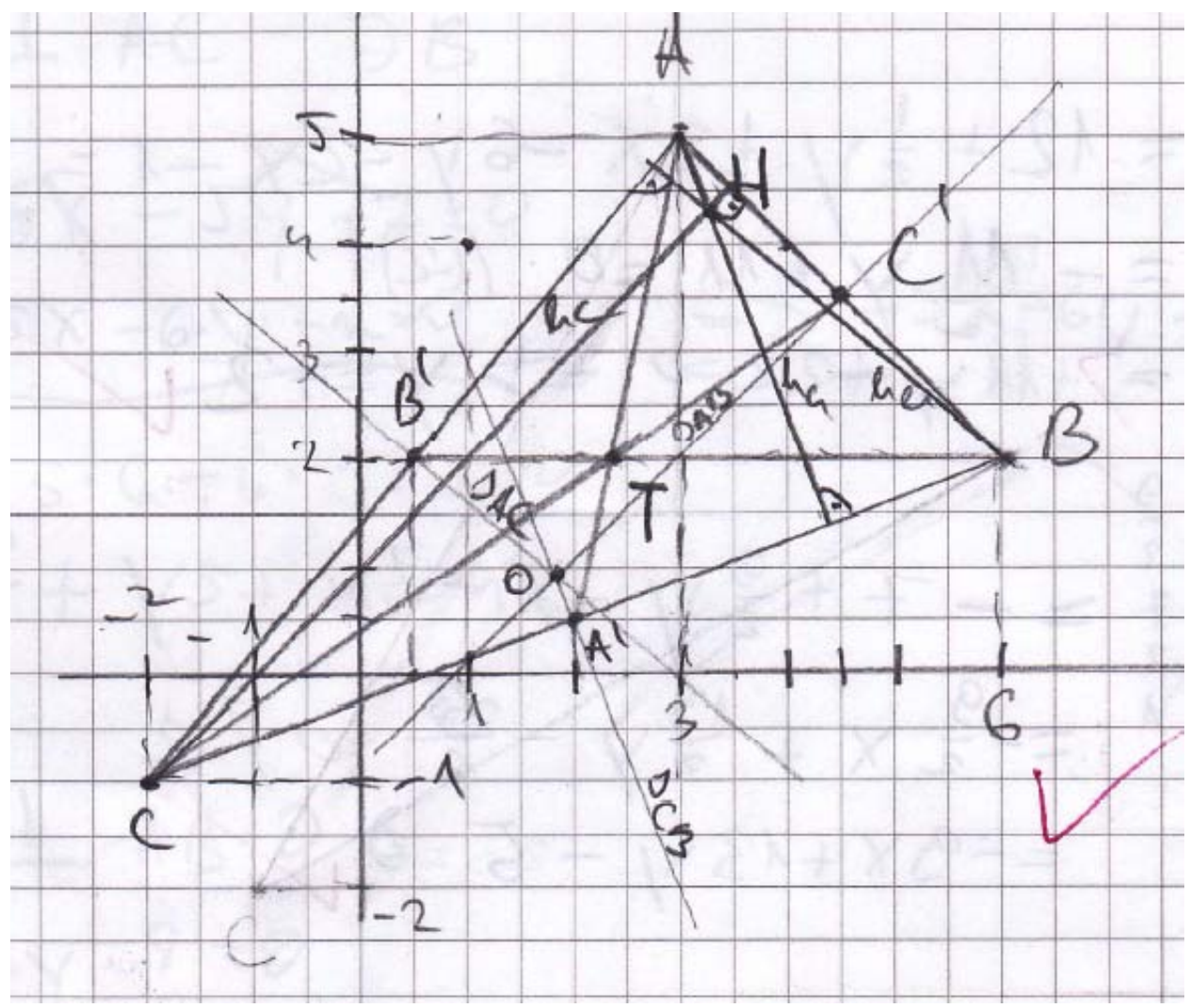

- At the end they had to prove the vector-theorem of the Euler's line:

$$
\begin{aligned}
& \text { Setel eriony } \\
& 2 \overrightarrow{O F}=\overrightarrow{T H} \\
& \overrightarrow{O T}=\left[\begin{array}{l}
\frac{7}{3}-\frac{41}{22} \\
2-\frac{19}{22}
\end{array}\right]=\left[\begin{array}{l}
\frac{31}{66} \\
\frac{25}{22}
\end{array}\right] \\
& \overrightarrow{T H}=\left[\begin{array}{ll}
\frac{36}{11}-\frac{7}{3} \\
\frac{47}{11}-2
\end{array}\right]=\left[\begin{array}{l}
\frac{31}{33} \\
\frac{25}{11}
\end{array}\right] \\
& 2 \cdot \overrightarrow{O T}=2 \cdot\left[\begin{array}{l}
\frac{31}{66} \\
\frac{25}{22}
\end{array}\right]=\left[\begin{array}{l}
\frac{2 \cdot 31}{6633} \\
\frac{2 \cdot 25}{2211}
\end{array}\right]=\left[\begin{array}{c}
\frac{31}{33} \\
\frac{25}{11}
\end{array}\right] \Rightarrow 2 \overrightarrow{O T}=\overrightarrow{T H}
\end{aligned}
$$




\section{Results}

The result of this test was very good. The first step that can be evaluated is to find the sides of the triangle, their midpoints, altitudes and orthocenter. The second step is to find the medians and barycenter, the third step is to find the circumcenter. The end is to check if the centroid $T$ lies on the line $H O$ and then to prove the ratio of vector $\overrightarrow{H O}$ to vector $\overrightarrow{T O}$, which is $2: 1$. A similar test was written by the generation before. The results are in the table below:

\begin{tabular}{|c|c|c|c|c|}
\hline Generation & First steps & Centroid & Circumcenter & Euler's line \\
\hline 2007 & 4 & 2 & 2 & 10 \\
2006 & 3 & 4 & 5 & 8 \\
\hline
\end{tabular}

It shows that 40 percent of the class in 2008 of 20 students; and 56 percent of the class in 2009 of 18 students executed the task an excellent mark. But this is only for special cases done. Proof of the theorem is for every point anywhere in the Descartes-coordinate plane, what one has to write in analytical form to prove in general form. That is not an easy task.

Every line (the sides of the triangles, the altitudes, the medians) and their intersection points must be expressed across the tree given vertices: $A\left(a_{1}, a_{2}\right), B\left(b_{1}, b_{2}\right)$ and $C\left(c_{1}, c_{2}\right)$. Software "Mathematica 6.2" is available to our students, and in cases like this, it is great support. It requires practical experiences, and the year before this lesson was not so well-done, as only one student succeed to get all the results correctly during $2 \cdot 45$ minutes (the causes were slow typing, imprecise calculation and formulation). But the following year it was successfully arranged, and the students achieved the results and realized the plan in total. Success depends on the students' thirst for knowledge, their empirical and practical experiences before the lesson, and the composition of the class. If there is great enthusiasm, that leads the students to find more and more results, it helps to turn up trumps, what is a new challenge after the first experiences. 


\subsection{General form of Euler's line}

Analytical geometry is a powerful "artifact" to prove theorems in geometry, if one find the appropriate model. Let the coordinates of the vertices of the triangle $\triangle A B C$ be $A\left(a_{1}, a_{2}\right)$, $B\left(b_{1}, b_{2}\right)$ and $C\left(c_{1}, c_{2}\right)$, find the equation of the Euler's line which contains points $H$ (orthocenter), $T$ (barycenter) and $O$ (circumcenter) of the triangle. Check that does the barycenter $T$ incident on line $H O$.

The real mathematical proof of the theorem in Euler's line and the vector-equality in analytical form is more complicated to the arbitrary triangle. The use of software "Mathematica 6.2" helped so much here. This is the third software in use, despite of the DGS "Euklides" with synthetic proof, and DGS "GeoGebra" with trigonometrical proof and some special cases.

First step is to learn how it is possible to express the lines of the triangle in general form, if the vertices are given.

\subsubsection{The equations of the lines $A B, B C$ and $A C$}

It's easy to express the equation of the line with the determinant of the endpoints of the segment.

$$
\begin{aligned}
& A B:\left|\begin{array}{ccc}
a_{1} & b_{1} & x \\
a_{2} & b_{2} & y \\
1 & 1 & 1
\end{array}\right|=0 \\
& B C:\left|\begin{array}{ccc}
b_{1} & c_{1} & x \\
b_{2} & c_{2} & y \\
1 & 1 & 1
\end{array}\right|=0 \\
& A C:\left|\begin{array}{ccc}
a_{1} & c_{1} & x \\
a_{2} & c_{2} & y \\
1 & 1 & 1
\end{array}\right|=0
\end{aligned}
$$

Every line through two points is expressible by the determinant, hence the equation of the sides of the triangle $A B C$ are:

$$
\begin{aligned}
& A B: a_{2} \cdot b_{1}+a_{1} \cdot b_{2}+a_{2} \cdot x-b_{2} \cdot x-a_{1} \cdot y+b_{1} \cdot y=0, \\
& B C: b_{2} \cdot c_{1}-b_{1} \cdot c_{2}-b_{2} \cdot x+c_{2} \cdot x+b_{1} \cdot y-c_{1} \cdot y=0, \\
& A C: a_{2} \cdot c_{1}+a_{1} \cdot c_{2}+a_{2} \cdot x-c_{2} \cdot x-a_{1} \cdot y+c_{1} \cdot y=0 .
\end{aligned}
$$

\subsubsection{Altitudes and the orthocenter of the triangle}

Altitude of the triangle is perpendicular to the opposite side across the vertex.

$$
h_{a} \perp B C \wedge A \in h_{a}
$$

hence its slope is reciprocal to the slope of line BC with opposite sign.

$$
h_{a}:\left(b_{1}-c_{1}\right) x+\left(b_{2}-c_{2}\right) y+\left(c_{1}-b_{1}\right) a_{1}+\left(c_{2}-b_{2}\right) a_{2}=0 .
$$

Similarly

$$
h_{b} \perp A C \wedge B \in h_{b}
$$




$$
h_{b}:\left(a_{1}-c_{1}\right) x+\left(a_{2}-c_{2}\right) y+\left(c_{1}-a_{1}\right) b_{1}+\left(c_{2}-a_{2}\right) b_{2}=0 .
$$

Their intersection point is $H$, the orthocenter of the triangle. We don't need to describe the third altitude, it must be incident with $H$, too. The solution of the system of equations 5.1 and 5.2 is $(x, y)=\left(h_{1}, h_{2}\right)$, the coordinates of orthocenter $H$.

$$
\begin{gathered}
h_{1}=-\frac{a_{1} a_{2} b_{1}+a_{2}^{2} b_{2}-a_{1} b_{1} b_{2}-a_{2} b_{2}^{2}-a_{1} a_{2} c_{1}+b_{1} b_{2} c_{1}-a_{2}^{2} c_{2}+b_{2}^{2} c_{2}+a_{1} c_{1} c_{2}-b_{1} c_{1} c_{2}}{-a_{2} b_{1}+a_{1} b_{2}+a_{2} c_{1}-b_{2} c_{1}-a_{1} c_{2}+b_{1} c_{2}} \\
+\frac{a_{2} c_{2}^{2}-b_{2} c_{2}^{2}}{-a_{2} b_{1}+a_{1} b_{2}+a_{2} c_{1}-b_{2} c_{1}-a_{1} c_{2}+b_{1} c_{2}} \\
h_{2}=-\frac{a_{1}^{2} b_{1}-a_{1} b_{1}^{2}+a_{1} a_{2} b_{2}-a_{2} b_{1} b_{2}-a_{1}^{2} c_{1}+b_{1}^{2} c_{1}+a_{1} c_{1}^{2}-b_{1} c_{1}^{2}-a_{1} a_{2} c_{2}+b_{1} b_{2} c_{2}}{a_{2} b_{1}-a_{1} b_{2}-a_{2} c_{1}+b_{2} c_{1}+a 1 c_{2}-b_{1} c_{2}} \\
+\frac{a_{2} c_{1} c_{2}-b_{2} c_{1} c_{2}}{a_{2} b_{1}-a_{1} b_{2}-a_{2} c_{1}+b_{2} c_{1}+a 1 c_{2}-b_{1} c_{2}}
\end{gathered}
$$

The computer helps in calculating, but the operator has to know what to calculate.

Leadership is in the programmer's hand. The student has to know the algorithm of the process, the aim of the work, to lead the process to the end algorithmically. Using the computer made the work easier, however the main problem was solved in the student's mind.

\subsubsection{The medians and the barycenter}

The medians of the triangle are the lines joining each vertex with the midpoint of the opposite side. Let $A^{\prime}, B^{\prime}$ and $C^{\prime}$ be the midpoints of the segments $B C, A C$ and $A B$ respectively. Their coordinates are

$$
\begin{aligned}
& A^{\prime}\left(\frac{b_{1}+c_{1}}{2}, \frac{b_{2}+c_{2}}{2}\right), \\
& B^{\prime}\left(\frac{a_{1}+c_{1}}{2}, \frac{a_{2}+c_{2}}{2}\right),
\end{aligned}
$$

and

$$
C^{\prime}\left(\frac{b_{1}+a_{1}}{2}, \frac{b_{2}+a_{2}}{2}\right)
$$

Hence the equations of the medians are:

$$
\begin{aligned}
& A A^{\prime}:\left|\begin{array}{ccc}
a_{1} & \frac{b_{1}+c_{1}}{2} & x \\
a_{2} & \frac{b_{2}+c_{2}}{2} & y \\
1 & 1 & 1
\end{array}\right|=0, \\
& B B^{\prime}:\left|\begin{array}{ccc}
b_{1} & \frac{a_{1}+c_{1}}{2} & x \\
b_{2} & \frac{a_{2}+c_{2}}{2} & y \\
1 & 1 & 1
\end{array}\right|=0,
\end{aligned}
$$




$$
C C^{\prime}:\left|\begin{array}{ccc}
c_{1} & \frac{b_{1}+a_{1}}{2} & x \\
c_{2} & \frac{b_{2}+c_{2}}{2} & y \\
1 & 1 & 1
\end{array}\right|=0 .
$$

Every line through two points is expressible by the determinant, hence the equation of the medians are:

$$
\begin{aligned}
& A A^{\prime}:-\frac{a_{2} b_{1}}{2}+\frac{a_{1} b_{2}}{2}-\frac{a_{2} c_{1}}{2}+\frac{a_{1} c_{2}}{2}+a_{2} x-\frac{b_{2} x}{2}-\frac{c_{2} x}{2}-a_{1} y+\frac{b_{1} y}{2}+\frac{c_{1} y}{2}=0 \\
& B B^{\prime}: \frac{a_{2} b_{1}}{2}-\frac{a_{1} b_{2}}{2}-\frac{b_{2} c_{1}}{2}+\frac{b_{1} c_{2}}{2}-\frac{a_{2} x}{2}+b_{2} x-\frac{c_{2} x}{2}+\frac{a_{1} y}{2}-b_{1} y+\frac{c_{1} y}{2}=0 \\
& C C^{\prime}: \frac{a_{2} c_{1}}{2}+\frac{b_{2} c_{1}}{2}-\frac{a_{1} c_{2}}{2}-\frac{b_{1} c_{2}}{2}-\frac{a_{2} x}{2}-\frac{b_{2} x}{2}+c_{2} x+\frac{a_{1} y}{2}+\frac{b_{1} y}{2}-c_{1} y=0
\end{aligned}
$$

Their intersection point is the centroid(barycenter), but there is another way to find it. The barycenter or the centroid of a triangle is the point of intersection of its medians. The centroid divides each of the medians in the ratio $2: 1$. Its coordinates are the means of the coordinates of the three vertices. That is, if the three vertices are $A\left(a_{1}, a_{2}\right), B\left(b_{1}, b_{2}\right)$ and $C\left(c_{1}, c_{2}\right)$, then the coordinates of the centroid $T\left(t_{1}, t_{2}\right)$ are

$$
t_{1}=\frac{1}{3}\left(a_{1}+b_{1}+c_{1}\right)
$$

and

$$
t_{2}=\frac{1}{3}\left(a_{2}+b_{2}+c_{2}\right)
$$

\subsubsection{The perpendicular bisectors and the circumcenter}

The circumcenter is the center of a triangle's circumcircle. It can be found as the intersection of the perpendicular bisectors. Let $s_{A B}, s_{B C}$ and $s_{A C}$ be the bisectors of the segment $\mathrm{AB}, \mathrm{BC}$ and $\mathrm{AC}$ respectively. Then they are

$$
\begin{aligned}
& s_{A B}: x\left(a_{1}-b_{1}\right)+y\left(a_{2}-b_{2}\right)+\frac{b_{1}^{2}-a_{1}^{2}}{2}+\frac{b_{2}^{2}-a_{2}^{2}}{2}=0, \\
& s_{A C}: x\left(a_{1}-c_{1}\right)+y\left(a_{2}-c_{2}\right)+\frac{c_{1}^{2}-a_{1}^{2}}{2}+\frac{c_{2}^{2}-a_{2}^{2}}{2}=0 .
\end{aligned}
$$

Their intersection point is $O\left(o_{1}, o_{2}\right)$, with coordinates

$$
\begin{gathered}
o_{1}=\frac{a_{2} b_{1}^{2}-a_{1}^{2} b_{2}-a_{2}^{2} b_{2}+a_{2} b_{2}^{2}-a_{2} c_{1}^{2}+b_{2} c_{1}^{2}+a_{1}^{2} c_{2}+a_{2}^{2} c_{2}-b_{1}^{2} c_{2}-b_{2}^{2} c_{2}-a_{2} c_{2}^{2}+b_{2} c_{2}^{2}}{2\left(a_{2} b_{1}-a_{1} b_{2}-a_{2} c_{1}+b_{2} c_{1}+a_{1} c_{2}-b_{1} c_{2}\right)} \\
o_{2}=-\frac{-a_{1}^{2} b_{1}-a_{2}^{2} b_{1}+a_{1} b_{1}^{2}+a_{1} b_{2}^{2}+a_{1}^{2} c_{1}+a_{2}^{2} c_{1}-b_{1}^{2} c_{1}-b_{2}^{2} c_{1}-a_{1} c_{1}^{2}+b_{1} c_{1}^{2}-a_{1} c_{2}^{2}+b_{1} c_{2}^{2}}{2\left(a_{2} b_{1}-a_{1} b_{2}-a_{2} c_{1}+b_{2} c_{1}+a_{1} c_{2}-b_{1} c_{2}\right)} .
\end{gathered}
$$

\subsubsection{The equation of the line $\mathrm{HO}$}

Euler's line contains points $H, T$ and $O$, its equation is determinant of coordinates $H\left(h_{1}, h_{2}\right)$ and $O\left(o_{1}, o_{2}\right)$ and finally check if the third point, $T$ belongs to that line $H O$, with equation

$$
\left|\begin{array}{ccc}
o_{1} & h_{1} & x \\
o_{2} & h_{2} & y \\
1 & 1 & 1
\end{array}\right|=0
$$


A little calculation to find the answer:

$$
T \in H O
$$

if and only if

$$
\left|\begin{array}{ccc}
o_{1} & h_{1} & t_{1} \\
o_{2} & h_{2} & t_{2} \\
1 & 1 & 1
\end{array}\right|=0,
$$

which is true. The equation of Euler's line is in the Appendix 5 made in "Mathematica $6.2 "$.

\subsubsection{The coordinates of vectors $\mathrm{HT}$ and TO}

The coordinates of the vector $\overrightarrow{H T}$ can be calculated as the difference of the coordinates of the initial vertex $T\left(t_{1}, t_{2}\right)$ and the terminal vertex $H\left(h_{1}, h_{2}\right)$.

$$
\overrightarrow{H T}=\left[\begin{array}{l}
t_{1} \\
t_{2}
\end{array}\right]-\left[\begin{array}{l}
h_{1} \\
h_{2}
\end{array}\right]
$$

The coordinates of the vector $T O$ can be calculated as the difference of the coordinates of the initial vertex $O\left(o_{1}, o_{2}\right)$ and terminal vertex $T\left(t_{1}, t_{2}\right)$.

Check if the vectors are collinear:

$$
\overrightarrow{T O}=\left[\begin{array}{l}
o_{1} \\
o_{2}
\end{array}\right]-\left[\begin{array}{l}
t_{1} \\
t_{2}
\end{array}\right]
$$

$$
\overrightarrow{H T}=2 \cdot \overrightarrow{T O}
$$

Remarks overheard during students' work:

Student V.O.: Coordinate $O_{1}$ is correct, but what could $h_{2}$ be?

Student S.M.: Couldn't we maybe prove that it's not zero?

Student K.R.: Syntax error! (comma, minus sign or space?)

Student P.A.: Wow, I got it! It's so beautiful! Awesome!

Student R.A.: This proof really made my day! (said slightly cynically)

\section{Summary}

Using a computer in complicated calculations helps to reach the main purpose, aim: theorems had been proven synthetically by elementary methods of axiomatically built Euclidean geometry, then they were proven in trigonometry and after in general form by analytical geometry. The principle of spirality to deepen the students' geometrical knowledge is observable here.

The students' reactions during work on the computer show that this method is a motivating factor in the teaching-learning process. In my opinion this kind of exploring of analytical geometry is a successful form of learning. 


\subsection{Ceva's theorem}

Given a triangle $\mathrm{ABC}$, and points $D, E$, and $F$ that lie on lines $B C, C A$, and $A B$ respectively, then lines $A D, B E$ and $C F$ are concurrent if and only if

$$
\frac{A F}{F B} \cdot \frac{B D}{D C} \cdot \frac{C E}{E A}=1
$$

Let the coordinates of the vertices of the triangle $\triangle A B C$ be $A\left(a_{1}, a_{2}\right), B\left(b_{1}, b_{2}\right)$ and $C\left(c_{1}, c_{2}\right)$, then the lines of the triangle are

$$
\begin{aligned}
& A B:\left|\begin{array}{ccc}
a_{1} & b_{1} & x \\
a_{2} & b_{2} & y \\
1 & 1 & 1
\end{array}\right|=0, \\
& B C:\left|\begin{array}{ccc}
b_{1} & c_{1} & x \\
b_{2} & c_{2} & y \\
1 & 1 & 1
\end{array}\right|=0, \\
& A C:\left|\begin{array}{ccc}
a_{1} & c_{1} & x \\
a_{2} & c_{2} & y \\
1 & 1 & 1
\end{array}\right|=0 .
\end{aligned}
$$

Every line through two points is expressible by the determinant, hence the equation of the sides of the triangle $\triangle A B C$ are:

$$
\begin{aligned}
& A B: a_{2} \cdot b_{1}+a_{1} \cdot b_{2}+a_{2} \cdot x-b_{2} \cdot x-a_{1} \cdot y+b_{1} \cdot y=0, \\
& B C: b_{2} \cdot c_{1}-b_{1} \cdot c_{2}-b_{2} \cdot x+c_{2} \cdot x+b_{1} \cdot y-c_{1} \cdot y=0, \\
& A C: a_{2} \cdot c_{1}+a_{1} \cdot c_{2}+a_{2} \cdot x-c_{2} \cdot x-a_{1} \cdot y+c_{1} \cdot y=0 .
\end{aligned}
$$

Let point $D\left(d_{1}, d_{2}\right)$ be on the segment $B C$, with coordinates $d_{1}$, which is arbitrarily chosen, and $d_{2}$, which must be expressed by $d_{1}$, then

$$
d_{2}=\frac{-b_{2} c_{1}+b_{1} c_{2}+b_{2} d_{1}-c_{2} d_{1}}{b_{1}-c_{1}} .
$$

Let point $F\left(f_{1}, f_{2}\right)$ be on the segment $A B$, with coordinates $f_{1}$ arbitrarily chosen and $f_{2}$, which must be expressed by $f_{1}$ :

$$
f_{2}=\frac{-a_{2} b_{1}+a_{1} b_{2}+a_{2} f_{1}-b_{2} f_{1}}{a_{1}-b_{1}} .
$$

Two lines $C F$ and $A D$ have equations created by the determinants:

$$
\begin{gathered}
C F:\left|\begin{array}{ccc}
c_{1} & f_{1} & x \\
c_{2} & \frac{-a_{2} b_{1}+a_{1} b_{2}+a_{2} f_{1}-b_{2} f_{1}}{a_{1}-b_{1}} & y \\
1 & 1 & 1
\end{array}\right|=0, \\
A D:\left|\begin{array}{ccc}
a_{1} & d_{1} & x \\
a_{2} & \frac{-b_{2} c_{1}+b_{1} c_{2}+b_{2} d_{1}-c_{2} d_{1}}{b_{1}-c_{1}} & y \\
1 & 1 & 1
\end{array}\right|=0 .
\end{gathered}
$$

Let $S\left(s_{1}, s_{2}\right)$ be the intersection point of the lines $A D$ and $C F$, then its coordinates are

$$
s_{1}=-\frac{-a_{1} b_{1} c_{1}+a_{1} c_{1} d_{1}+a_{1} c_{1} f_{1}-a_{1} d_{1} f_{1}+b_{1} d_{1} f_{1}-c_{1} d_{1} f_{1}}{a_{1} b_{1}-a_{1} c_{1}+b_{1} c_{1}-b_{1} d_{1}-b_{1} f_{1}+d_{1} f_{1}},
$$




$$
\begin{aligned}
s_{2}= & -\frac{-a_{2} b_{1} c_{1}+a_{1} b_{2} c_{1}-a_{1} b_{1} c_{2}+a_{2} b_{1} d_{1}-a_{1} b_{2} d_{1}+a_{1} c_{2} d_{1}}{a_{1} b_{1}-a_{1} c_{1}+b_{1} c_{1}-b_{1} d_{1}-b_{1} f_{1}+d_{1} f_{1}}+ \\
& +\frac{a_{2} c_{1} f_{1}-b_{2} c_{1} f_{1}+b_{1} c_{2} f_{1}-a_{2} d_{1} f_{1}+b_{2} d_{1} f_{1}-c_{2} d_{1} f_{1}}{a_{1} b_{1}-a_{1} c_{1}+b_{1} c_{1}-b_{1} d_{1}-b_{1} f_{1}+d_{1} f_{1}} .
\end{aligned}
$$

The third line, BS has the following equation:

$$
B S:\left|\begin{array}{ccc}
b_{1} & s_{1} & x \\
b_{2} & s_{2} & y \\
1 & 1 & 1
\end{array}\right|=0 .
$$

The third point, $E\left(e_{1}, e_{2}\right)$ is the intersection point of the lines $B S$ and $A C$ :

$$
\begin{gathered}
e_{1}=-\frac{-2 a_{1} b_{1} c_{1}+a_{1} b_{1} d_{1}+a_{1} c_{1} d_{1}+a_{1} c_{1} f_{1}+b_{1} c_{1} f_{1}-a_{1} d_{1} f_{1}-c_{1} d_{1} f_{1}}{a_{1} b_{1}+b_{1} c_{1}-a_{1} d_{1}-b_{1} d_{1}-b_{1} f_{1}-c_{1} f_{1}+2 d_{1} f_{1}}, \\
e_{2}=-\frac{-a_{2} b_{1} c_{1}-a_{1} b_{1} c_{2}+a_{2} b_{1} d_{1}+a_{1} c_{2} d_{1}+a_{2} c_{1} f_{1}+b_{1} c_{2} f_{1}-a_{2} d_{1} f_{1}-c_{2} d_{1} f_{1}}{a_{1} b_{1}+b_{1} c_{1}-a_{1} d_{1}-b_{1} d_{1}-b_{1} f_{1}-c_{1} f_{1}+2 d_{1} f_{1}} .
\end{gathered}
$$

To find the value of formula (5.5) we have to calculate the length of the segments

$$
\begin{gathered}
{[A F]=\sqrt{\left(a_{1}-f_{1}\right)^{2}+\left(a_{2}-\frac{-a_{2} b_{1}+a_{1} b_{2}+a_{2} f_{1}-b_{2} f_{1}}{a_{1}-b_{1}}\right)^{2}},} \\
{[F B]=\sqrt{\left(f_{1}-b_{1}\right)^{2}+\left(\frac{-a_{2} b_{1}+a_{1} b_{2}+a_{2} f_{1}-b_{2} f_{1}}{a_{1}-b_{1}}-b_{2}\right)^{2}},} \\
{[B D]=\sqrt{\left(b_{1}-d_{1}\right)^{2}+\left(b_{2}-\frac{-b_{2} c_{1}+b_{1} c_{2}+b_{2} d_{1}-c_{2} d_{1}}{b_{1}-c_{1}}\right)^{2}},} \\
{[D C]=\sqrt{\left(d_{1}-c_{1}\right)^{2}+\left(\frac{-b_{2} c_{1}+b_{1} c_{2}+b_{2} d_{1}-c_{2} d_{1}}{b_{1}-c_{1}}-c_{2}\right)^{2}},} \\
{[C E]=\sqrt{\left(c_{1} 9-e_{1}\right)^{2}+\left(c_{2}-e_{2}\right)^{2}},} \\
{[E A]=\sqrt{\left(e_{1}-a_{1}\right)^{2}+\left(e_{2}-a_{2}\right)^{2}} .}
\end{gathered}
$$

Checking the form (5.5) of Ceva's theorem, the product of the proportion of the segments must be 1 . Using the computer it is simple to verify this. It looks like long and accurate work, but with "copy-paste" operations one can finish this procedure very fast. Of course, experience and routine play great role in the success. At the end of the deduction students usually print their own work, because there is an option to print the mathematica/notebook in .nb format or .pdf format. The deduction created by "Mathematica 6.2 " is in Appendix 3. Indexes are not small subscribed elements, because they caused problems and led to syntax errors. 


\subsection{Menelaus' theorem}

Given points $A\left(a_{1}, a_{2}\right), B\left(b_{1}, b_{2}\right)$ and $C\left(c_{1}, c_{2}\right)$ that form triangle $\triangle A B C$, and points $D$, $E, F$ that lie on lines $B C, A C, A B$, then points $D, E, F$ are collinear if and only if

$$
\frac{\overline{A F}}{\overline{F B}} \cdot \frac{\overline{B D}}{\overline{D C}} \cdot \frac{\overline{C E}}{\overline{E A}}=-1 \text {, }
$$

where $\overline{A F}$ denotes the directed edge from the terminal vertex $A$ to the initial vertex $F$. Let the coordinates of the vertices of the triangle $\triangle A B C$ be $A\left(a_{1}, a_{2}\right), B\left(b_{1}, b_{2}\right)$ and $C\left(c_{1}, c_{2}\right)$, then the lines of the triangle are as above

$$
\begin{aligned}
& A B:\left|\begin{array}{ccc}
a_{1} & b_{1} & x \\
a_{2} & b_{2} & y \\
1 & 1 & 1
\end{array}\right|=0, \\
& B C:\left|\begin{array}{ccc}
b_{1} & c_{1} & x \\
b_{2} & c_{2} & y \\
1 & 1 & 1
\end{array}\right|=0, \\
& A C:\left|\begin{array}{ccc}
a_{1} & c_{1} & x \\
a_{2} & c_{2} & y \\
1 & 1 & 1
\end{array}\right|=0 .
\end{aligned}
$$

Every line through two points is expressible by the determinant, hence the equation of the sides of the triangle $\triangle A B C$ are:

$$
\begin{aligned}
& A B: a_{2} \cdot b_{1}+a_{1} \cdot b_{2}+a_{2} \cdot x-b_{2} \cdot x-a_{1} \cdot y+b_{1} \cdot y=0, \\
& B C: b_{2} \cdot c_{1}-b_{1} \cdot c_{2}-b_{2} \cdot x+c_{2} \cdot x+b_{1} \cdot y-c_{1} \cdot y=0, \\
& A C: a_{2} \cdot c_{1}+a_{1} \cdot c_{2}+a_{2} \cdot x-c_{2} \cdot x-a_{1} \cdot y+c_{1} \cdot y=0 .
\end{aligned}
$$

Let point $D\left(d_{1}, d_{2}\right)$ be on the line $B C$, with coordinates $d_{1}$, which is arbitrarily chosen, and $d_{2}$, which must be expressed by $d_{1}$, than

$$
d_{2}=\frac{-b_{2} c_{1}+b_{1} c_{2}+b_{2} d_{1}-c_{2} d_{1}}{b_{1}-c_{1}}
$$

Let point $F\left(f_{1}, f_{2}\right)$ be on the line $A B$, with coordinates $f_{1}$, it is arbitrarily chosen and $f_{2}$, which must be expressed by $f_{1}$ :

$$
f_{2}=\frac{-a_{2} b_{1}+a_{1} b_{2}+a_{2} f_{1}-b_{2} f_{1}}{a_{1}-b_{1}}
$$

then the equation of the line $F D$ is

$$
F D:\left|\begin{array}{ccc}
f_{1} & d_{1} & x \\
f_{2} & d_{2} & y \\
1 & 1 & 1
\end{array}\right|=0
$$

The intersection point of the lines $A C$ and $F D$ is point $E\left(e_{1}, e_{2}\right)$ with coordinates

$$
e_{1}=-\frac{a_{1} b_{1} d_{1}-a_{1} c_{1} d_{1}+a_{1} c_{1} f_{1}-b_{1} c_{1} f_{1}-a_{1} d_{1} f_{1}+c_{1} d_{1} f_{1}}{-a_{1} b_{1}+b_{1} c_{1}+a_{1} d_{1}-b_{1} d_{1}+b_{1} f_{1}-c_{1} f_{1}}
$$




$$
e_{2}=-\frac{a_{2} b_{1} c_{1}-a_{1} b_{1} c_{2}-a_{2} b_{1} d_{1}+a_{1} c_{2} d_{1}-a_{2} c_{1} f_{1}+b_{1} c_{2} f_{1}+a_{2} d_{1} f_{1}-c_{2} d_{1} f_{1}}{a_{1} b_{1}-b_{1} c_{1}-a_{1} d_{1}+b_{1} d_{1}-b_{1} f_{1}+c_{1} f_{1}} .
$$

To find the value of formula (5.6) we have to check the length of the segments. At the end we have to calculate the product of proportions of the segments, and to check if its value is equal to 1 , which is a simple task.

The deduction created by "Mathematica 6.2" is in Appendix 4. Indexes are not small subscribed elements, because they caused problems in students' work and led to syntax errors.

\section{Summary}

The software "Mathematica 6.2" helps to calculate very long and complicated formulas and to simplify them is an easier process than one the human brain can do. The computer helps in calculating, but the operator has to know what to calculate. Leadership is in the programmer's hand. The student has to know the algorithm of the process, the aim of the work, to lead the process to the end algorithmically. Using the computer made the work easier, however the main problem was solved in the student's mind.

Visualization in geometry tasks helps the human mind understand the problem, to find the solution and to describe the result. If there is a complicated mathematics problem (not only in geometry), using drawings helps our brain find connections.

In geometry, accurate construction and measuring elements of the given figure highlight some relationships between the basic elements. A computer can calculate faster, and it is able to express complicated equations and to quickly simplify them, but the student is the commander of the logical process. 


\section{Apollonius' problems}

As an example of using inversion to a circle there are Problems of Apollonius, their constructions, discussion, analysis and proof. Those who have some experiences in construction using chalk on the blackboard with wooden compass and rulers have an idea of how to show and prove these interesting but difficult problems to their own students. The emphasis is on convincing instead of proving. A great help in visualization are some DGS , such as "Cinderella", "Geogebra", "Geonext" or "Euklides", etc.

As one can read in [34]:

"More sophisticated computer environments have been designed in recent years which take advantage of flexible computer interfaces Geometric software ... allows figures to be drawn with specific relationships defined, such as a given point must always lie at the midpoint of a given line-segment, or be constrained to lie on a given circle. Then the figure may be pulled around inactively retaining all defined constrains to investigate possible consequent relationships...Such software may be used to gain enactive visual support in conjecturing and testing geometric theorems, enabling students to take an active part in the construction of their own knowledge, though once again, the formal proof structure of geometry will need separate consideration."

In the first grade of grammar school DGS Euklides is used.

We construct particular solutions, and by moving the basic elements we can show every solution to the problem.

Constructional tasks are chosen to develop motor skills, accuracy and to find out the differences between conditions, assumptions and consequences. My aim is to develop the problem solving skills using visualizations on the computer, and to work out the recognition of axiomatically built geometry in the plane. Visualization helps students with lower achievement to understand the problems, but the highly gifted students enjoy the probabilities of the animation. They need this kind of visualization, as well, but with larger, more difficult problems to solve at their level.

\section{"It is so beautiful to find out special cases by dynamic movement of basic elements, measuring elements of the last figure"- pupils say.}

It is interesting for the teacher, as well, when pupils find more methods of solutions of the given task, different from the known solutions.

As David Tall says in [34]:

"With a computer tool capable of carrying out some of these processes, a new form of learning becomes feasible in which the individual can concentrate on constructing mental relationships that are important to conceptualization, 
whilst the computer carries out the routine algorithms. It is the task of educator to provide appropriate environments to focus on selected mathematical concepts or processes whilst suppressing routine algorithms carried out by the computer, to enable the learner to make selected mathematical constructions. i term this the principle of selective construction."

That is why my choice was the most difficult construction, Problems of Apollonius [22]. Usually, it is rather difficult for students to grasp the essence of these problems using traditional means, rulers and a compass, but the use of computers offers higher accuracy.

\subsection{Apollonius of Perga}

Apollonius (about 262 BC - about 190 BC) was a Greek mathematician known as 'The Great Geometer'. His works had a very great influence on the development of mathematics and his famous book Conics introduced the terms parabola, ellipse and hyperbola [36].

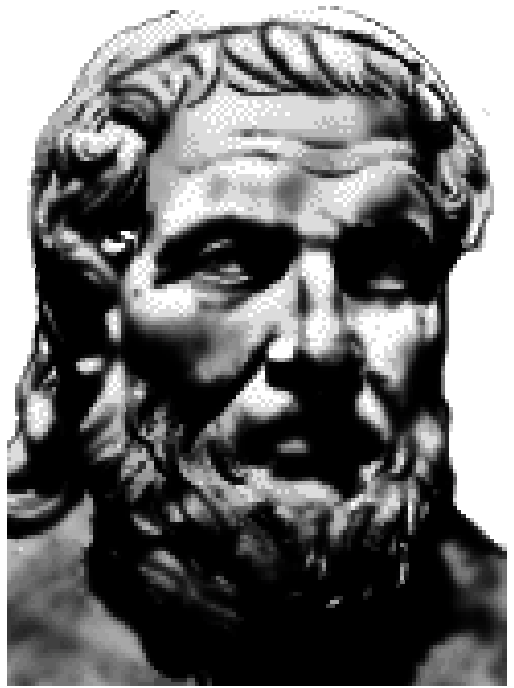

Pappus mentioned other treatises of Apollonius:

- De Rationis Sectione ("Cutting of a Ratio")

- De Spatii Sectione ("Cutting of an Area")

- De Sectione Determinata ("Determinate Section")

- De Tactionibus ("Tangencies")

- De Inclinationibus("Inclinations")

- De Locis Planis("Plane Loci")

In Book IV of Elements, Euclid [9] shows how to construct the circle that passes through three given points, and how to construct a circle tangent to three given straight lines. Apollonius of Perga subsequently generalized this by showing how to find a circle tangent to three objects in the plane, where the objects can be any combination of points, lines, and/or circles. The most general and difficult case is obviously the case of three circles, which was covered in Book II of Apollonius' "On Tangencies".

The basic problem is:

Given three objects, each of which may be a point, line, or circle, draw a circle that is tangent to each. 


\subsection{Ten cases}

1. THE CIRCLE CROSSES THREE GIVEN POINTS $A, B, C$.

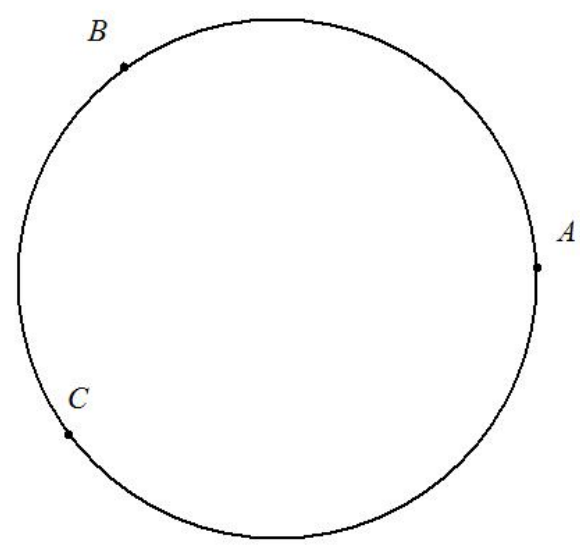

Solution: Three no collinear points $A, B, C$ determine triangle $A B C$, and its circumcircle is the searched circle. Its center is the intersection point of lines of symmetry of edges in triangle $A B C$.

Euclid [9] in the Book IV of The Elements in proposition 5 states:

"And it is manifest that when the center of the circle falls within the triangle, the angle $B A C$, being in a segment greater than the semicircle, is less than a right angle, when the center falls on the straight line $B C$, the angle $B A C$, being in a semicircle, is right, and when the center of the circle falls outside the triangle, the angle $B A C$, being in a segment less than the semicircle, is greater than a right angle."

Discussion: This problem always has a solution, if the given points aren't collinear points.

2. THE CIRCLE CROSSES TWO POINTS $A, B$, AND TOUCHES THE GIVEN LINE $p$

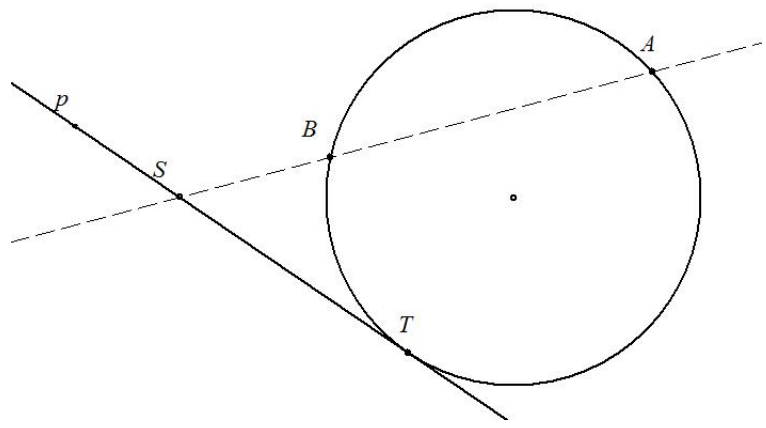

Solution: Let $T$ be the point of tangency of the given line $p$ and the circle, and let $S$ be the intersection point of lines $A B$ and $p$. Then $S A \cdot S B=S T^{2}$, because the product of the lengths of the whole secant and the part outside the circle is the same for every secant, and equal to the square of the tangential segment. This segment $S T$ is constructible with right angle triangle and its altitude. First construct point 
$S$, and then point $T$ on line $p$. Let line $n$ be perpendicular to line $p$ across point $T$, and let $s_{A B}$ be the bisector of segment $A B$.

The point of intersection of lines $n$ and $s_{A B}$ is the center of the circle.[16]

Discussion: Let $h$ be the distance of point $A$ from the line $p$, and similarly $H$ be the distance of point $B$ from line $p$ and $d=H-h$. This problem has solutions if and only if $0 \leq h \leq H, d \geq 0$.

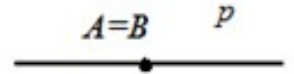

i) double points

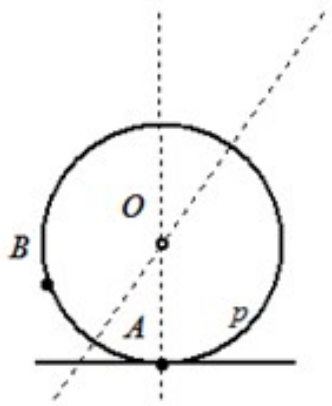

iv) one solution

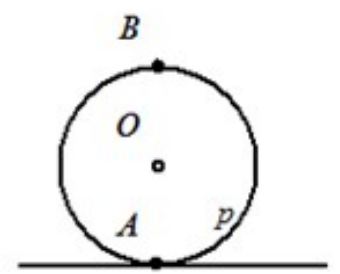

ii) circle with diameter $\mathrm{H}$

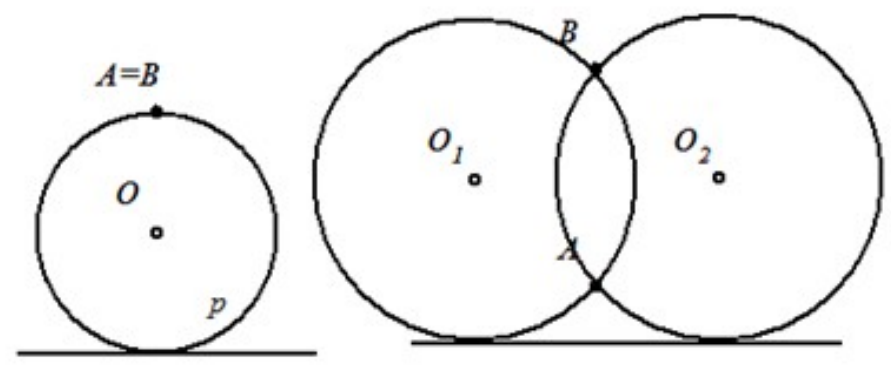

v) circle with diameter $\mathrm{H}$

vi) two solutions

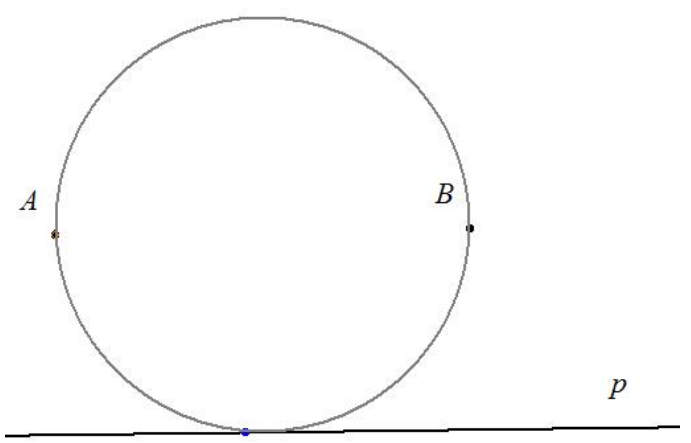

$\boldsymbol{v}$ ) if line $p$ is parallel to line $A B, H=h$, there is only one solution. 
3. THE CIRCLE ACROSS TWO POINTS $A, B$ TOUCHES THE GIVEN CIRCLE $l$

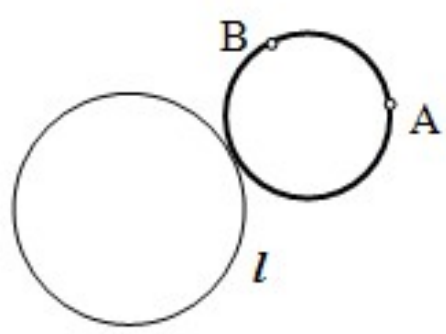

Solution: Use inversion $\psi_{i}(A, r)$ with center A and arbitrary radius r.

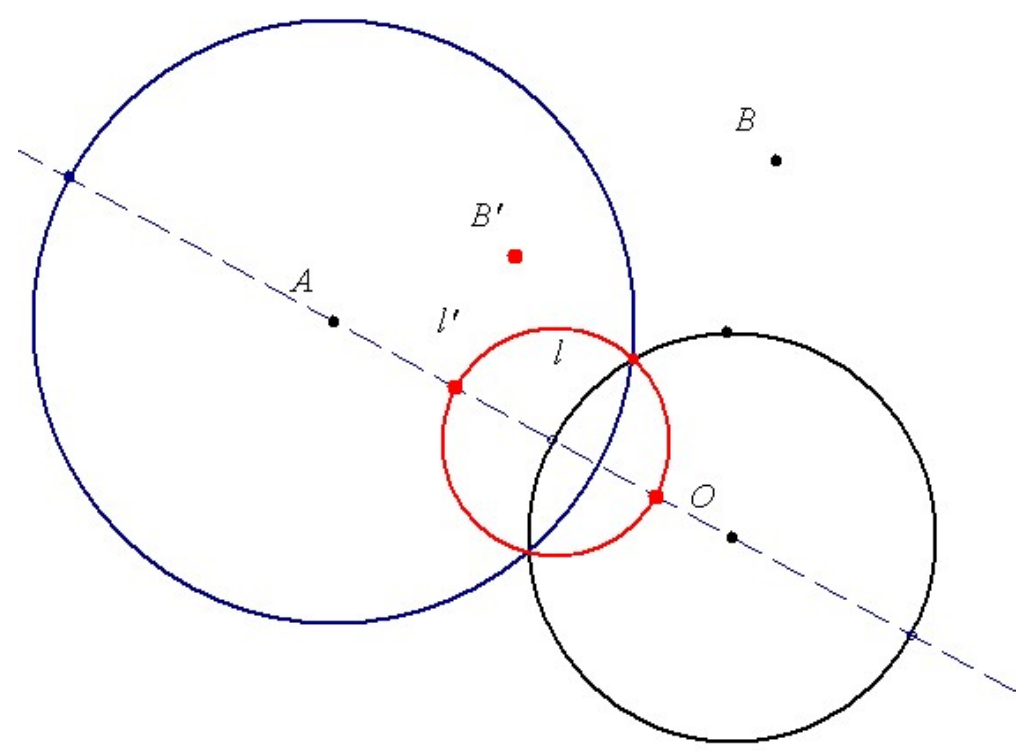

Let $l^{\prime}$ be the image of circle $l$ in that inversion, so this is a circle, if $A$ isn't on circle $l$, and $B^{\prime}=\psi_{i}(B)$.

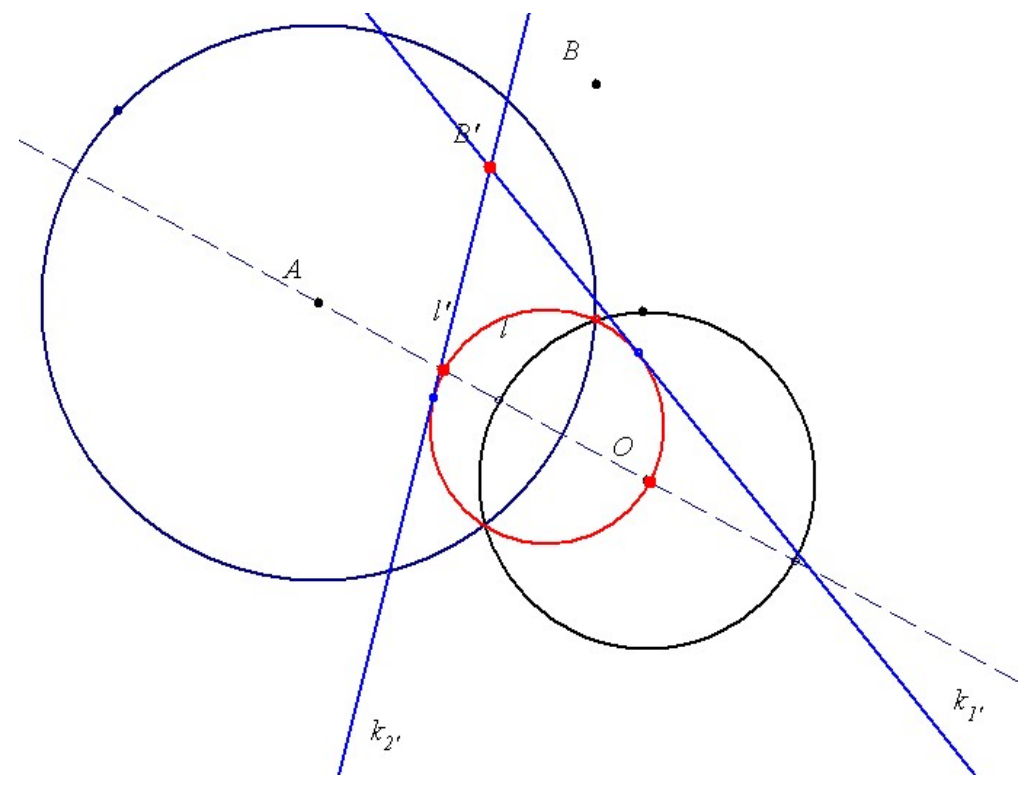


Construct tangencies $k_{1}^{\prime}$ and $k_{2}^{\prime}$ across point $B^{\prime}$ to circle $l^{\prime}$.

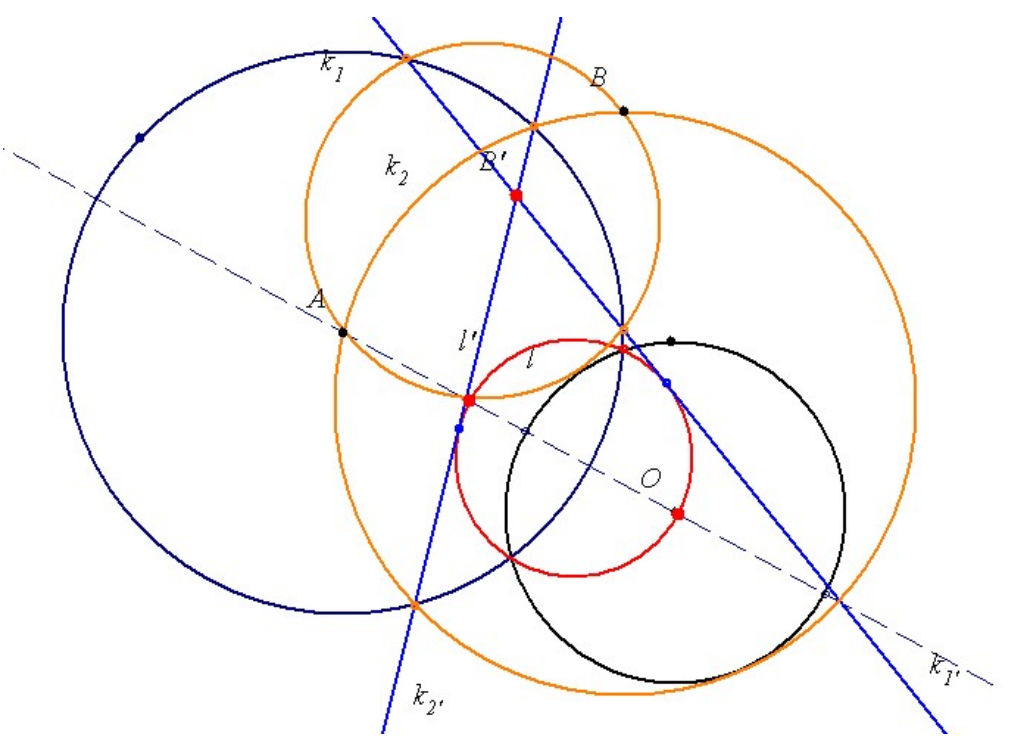

These lines $k_{1}^{\prime}$ and $k_{2}^{\prime}$ are images of the sought circle.

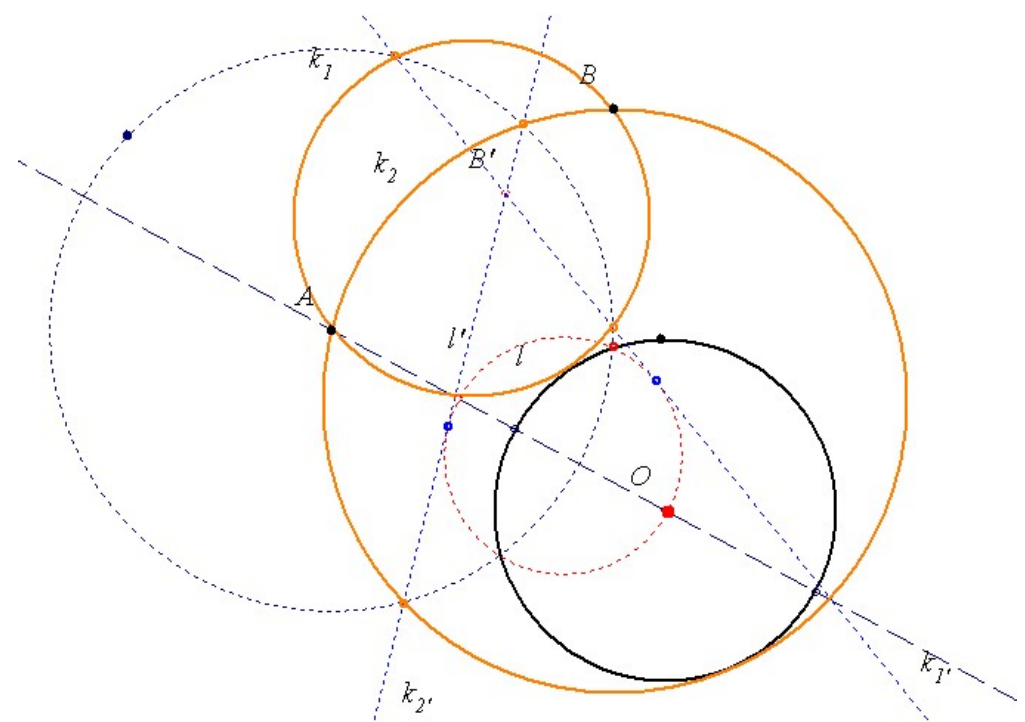

Using $\psi_{i}$ again there are two solutions of the given problem, because inversion is involution $\left(\psi_{i}^{2}\right.$ is identical transformation). 


\section{Discussion:}

i) If $A$ and $B$ are two different points outside the given circle, then there are two solutions.

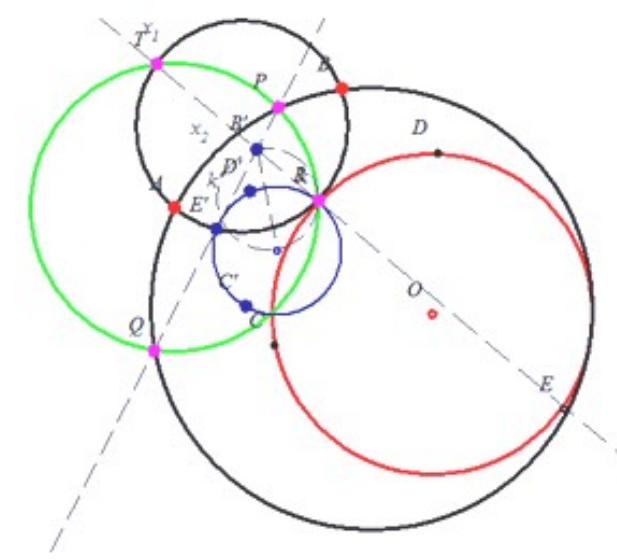

ii) If point $A$ (or point $B$ ) is on the circle $l$, and the other point is outside of the circle, there is only one solution.

iii) If point $A$ (or point $B$ ) is on the circle $l$, and the other point is inside of the circle, there is only one solution.

$\boldsymbol{i v}$ ) If both points are inside the circle $l$, there are two solutions.

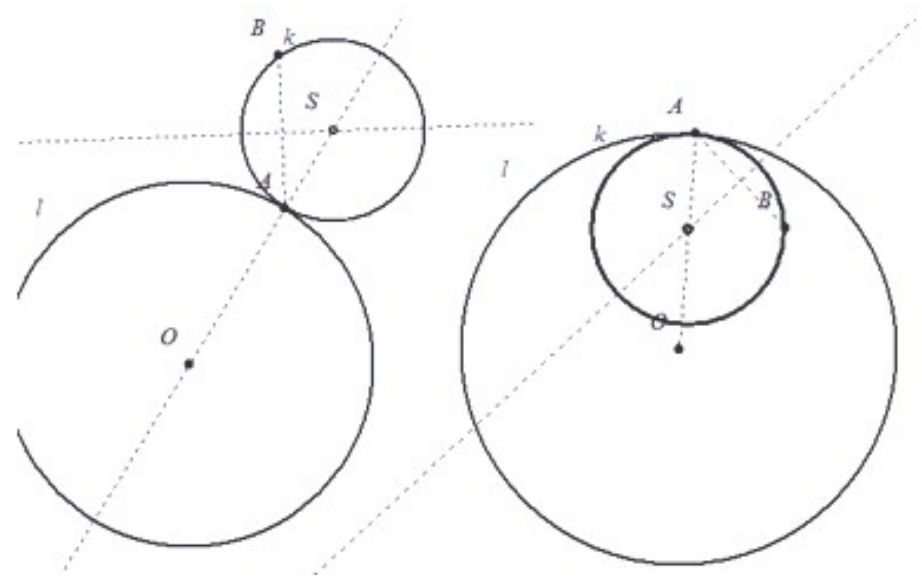

ii)

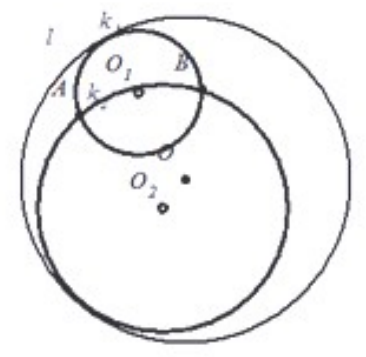

iv) 
4. THE CIRCLE ACROSS ONE POINT $A$ TOUCHES TWO GIVEN LINES $p, q$

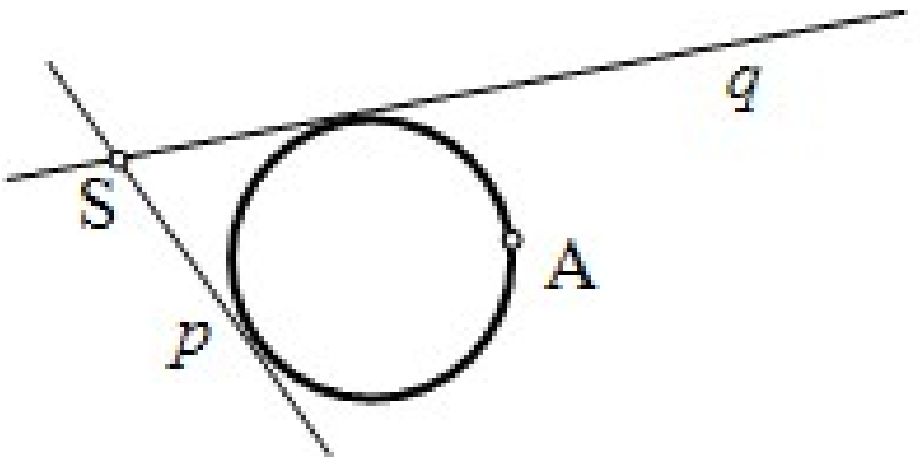

Solution: The center of an arbitrary circle which touches two lines $p$ and $q$ is on their angle bisector or their symmetry-line. Let $S$ be the intersection point of the given lines. Choosing one of these circles, and using dilatations $H_{S, \frac{S A}{S B}}(l)=k_{2}$ and $H_{S, \frac{S A}{S C}}(l)=k_{1}$ with center $S$ and coefficients $\frac{S A}{S B}$ and $\frac{S A}{S C}$, where points $B$ and $C$ are the intersection points of line $S A$ and that chosen circle, there are circles $k_{1}$ and $k_{2}$.

Discussion:

i) If the given lines have a common point or they are parallel and point $A$ isn't on these lines, there are two circles as solution.

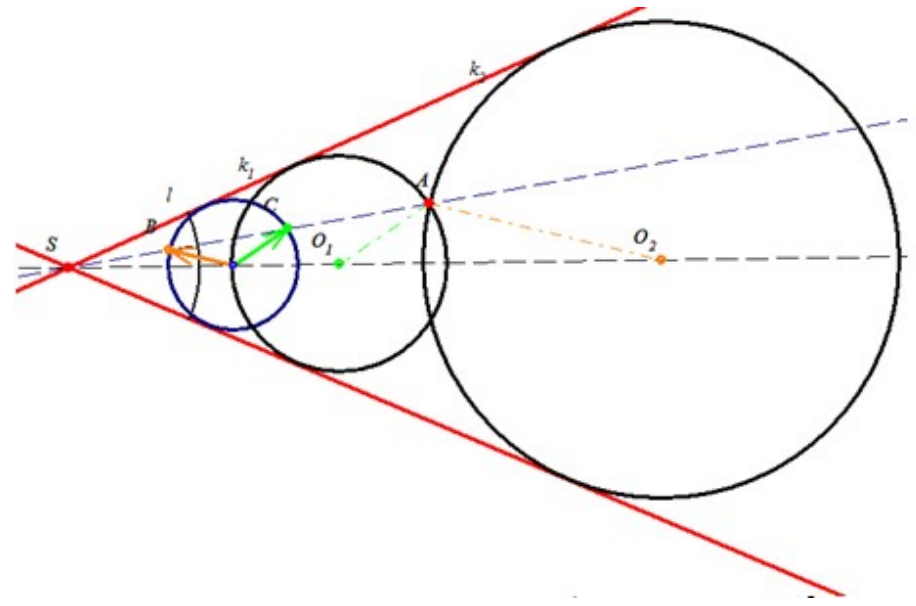

ii) If the given lines have a common point, and point $A$ is on one of them, there are two circles as solution.

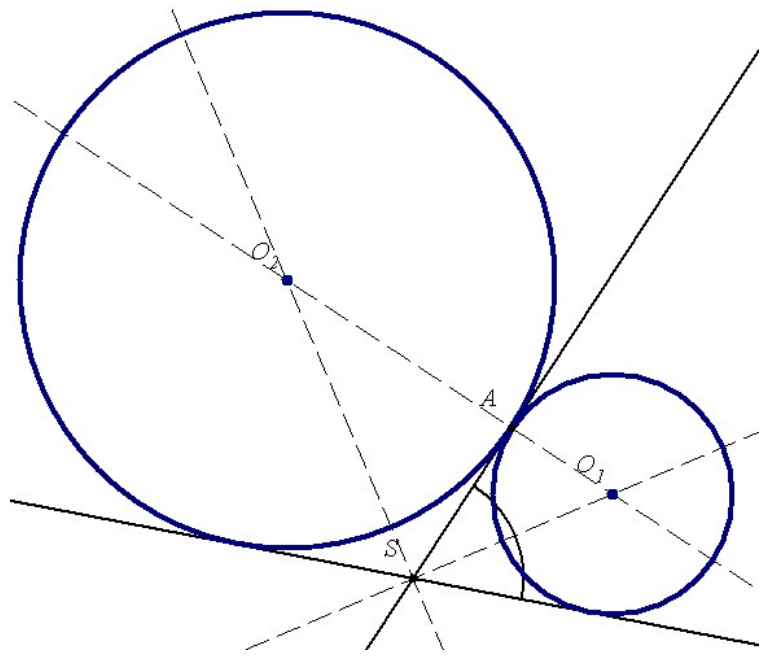


iii) If the given lines are parallel, and point $A$ is on one of them, then there is only one solution.

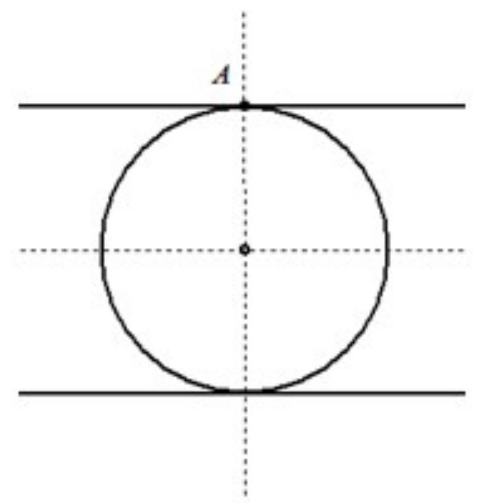

5. THE CIRCLE ACROSS ONE POINT $A$ TOUCHES THE GIVEN LINE $p$ AND THE GIVEN CIRCLE $l$

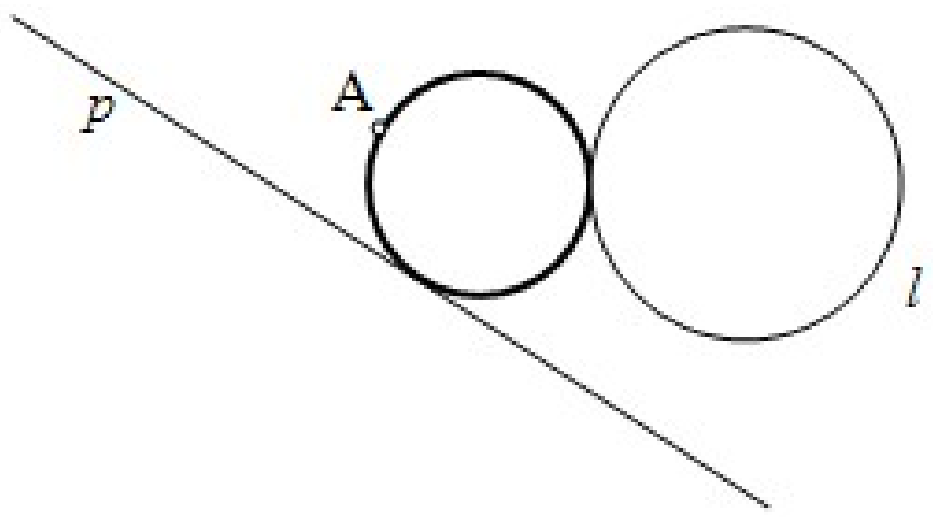

Solution: Using inversion $\psi_{i}(A, r)$ with center $A$ and arbitrary radius $r$ and transforming line $p$ and circle $l$ one can get the images $p^{\prime}$ and $l^{\prime}$ circles. Construct the common tangents $k_{1}^{\prime}, k_{2}^{\prime}, k_{3}^{\prime}$ and $k_{4}^{\prime}$ of these circles. The inverse images of these lines by using $\psi_{i}(A, r)$ again are circles $k_{1}, k_{2}, k_{3}$ and $k_{4}$.

Discussion: If point $A$ is neither on circle $l$ nor on line $p$, there are four solutions to that problem, because in this inversion $\psi_{i}(A, r)$ the image of the line $p$ is circle, so two circles without common points have four common tangents, two inside and two outside. 


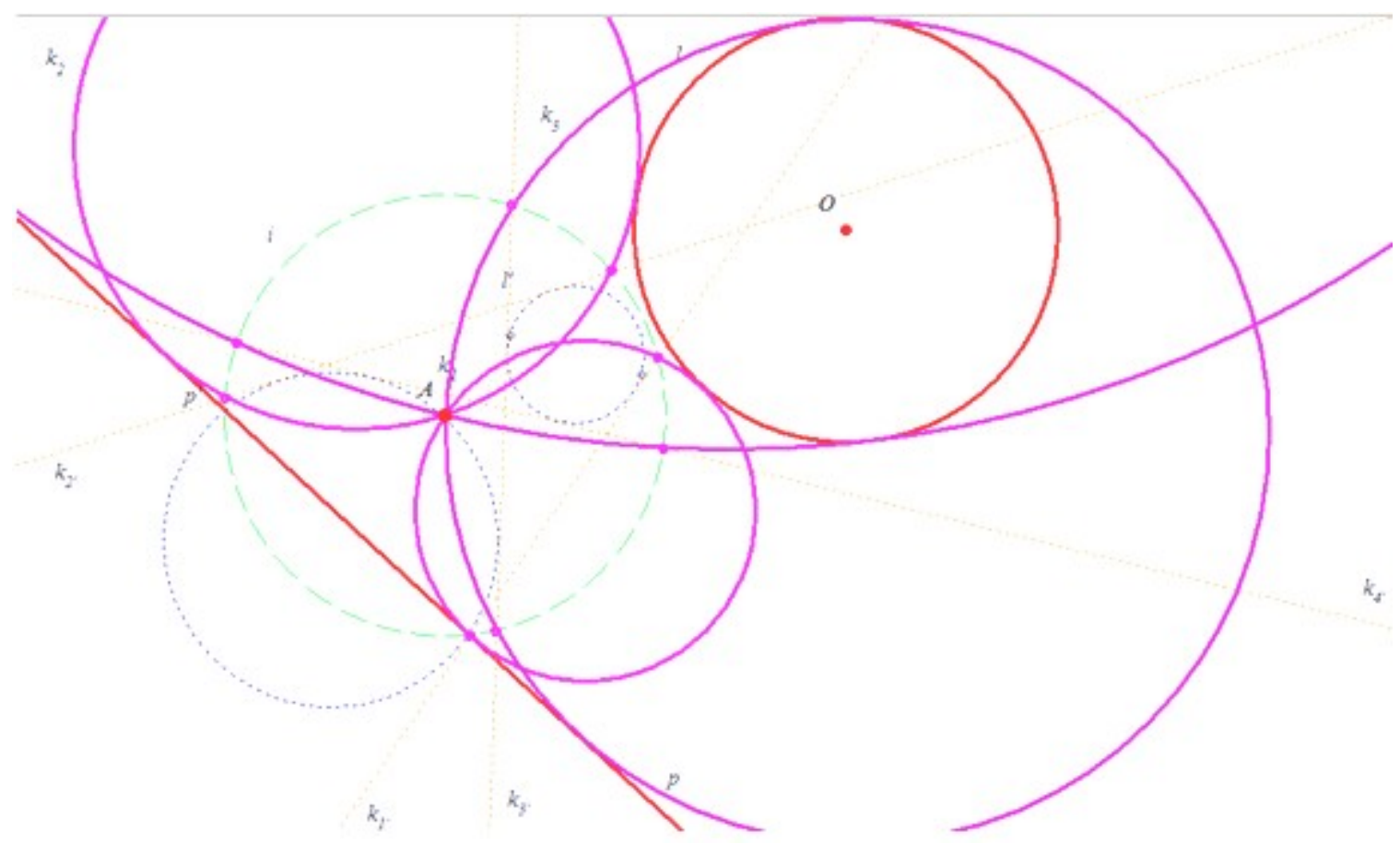

Here DGS (the dynamic geometry system) helps to find every possible solution of the problem moving basic elements (point, circle, line), and replacing them students can see the transformations. In "classical" construction it is almost impossible to find every solution. Drawing on blackboard using chalk rarely gives a precise construction. Rulers and compass in students' notebooks also require great precision. My students learn how to construct on paper and on the computer, too. Visualization helps in every step of solving the problems, (which we have learned from Pólya [19]):

(a) understanding the task,

(b) constructing the solution,

(c) controlling the problem and its solution.

6. THE CIRCLE ACROSS ONE POINT A TOUCHES

TWO GIVEN CIRCLES $l, m$

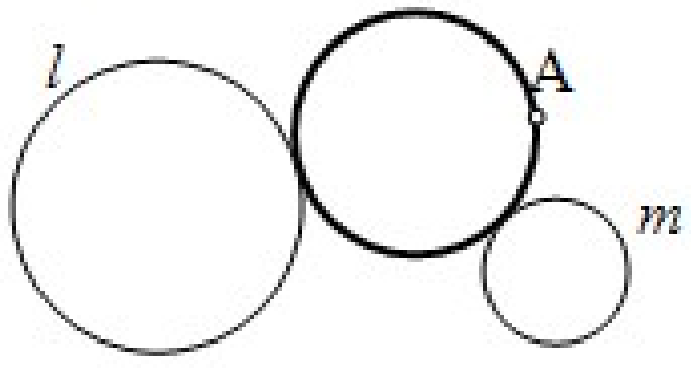

Solution: Using inversion $\psi_{i}(A, r)$ with center $A$ and arbitrary radius $r$ and transforming circles $l$ and $m$ one can get the images, they are circles $l^{\prime}$ and $m^{\prime}$. Construct the common tangents $k_{1}^{\prime}, k_{2}^{\prime}, k_{3}^{\prime}$ and $k_{4}^{\prime}$ of these circles. The inverse images of these 
lines using $\psi_{i}(A, r)$ again are circles $k_{1}, k_{2}, k_{3}$ and $k_{4}$.

The step by step construction is below:

i) beginning

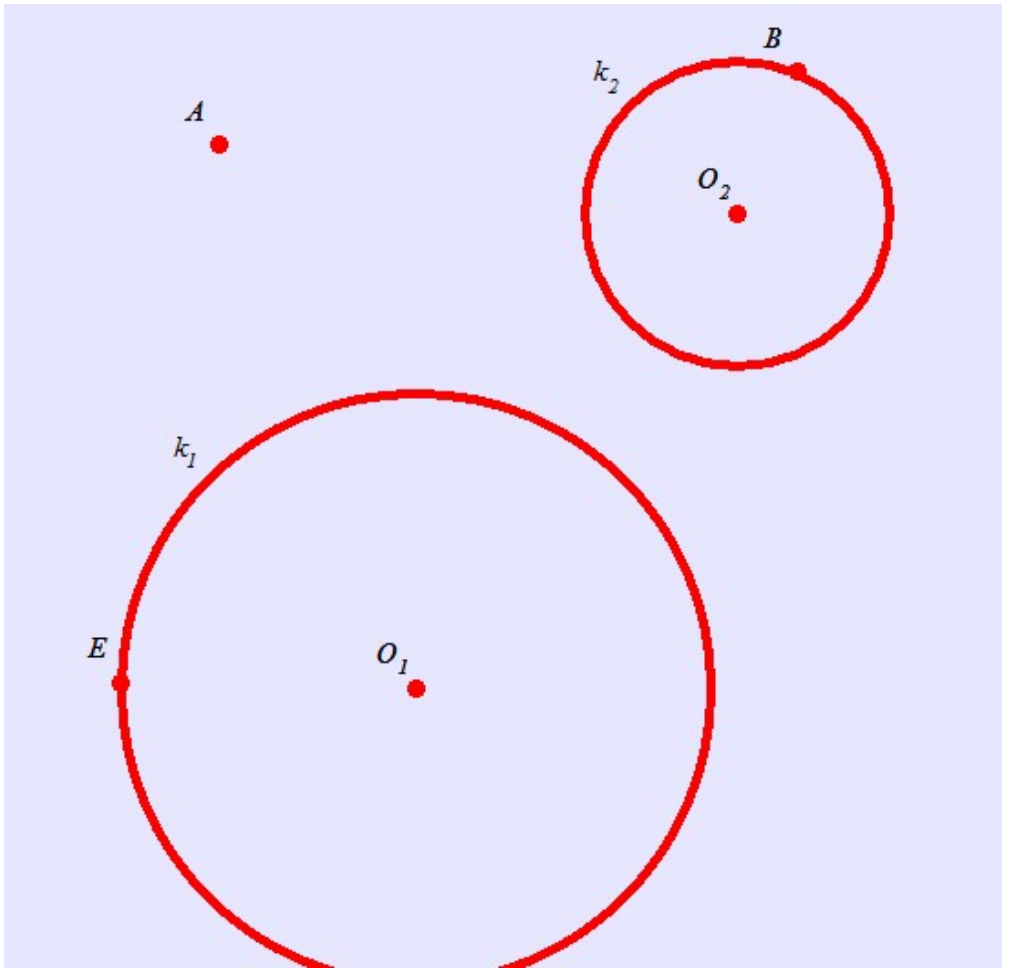

ii) inversion

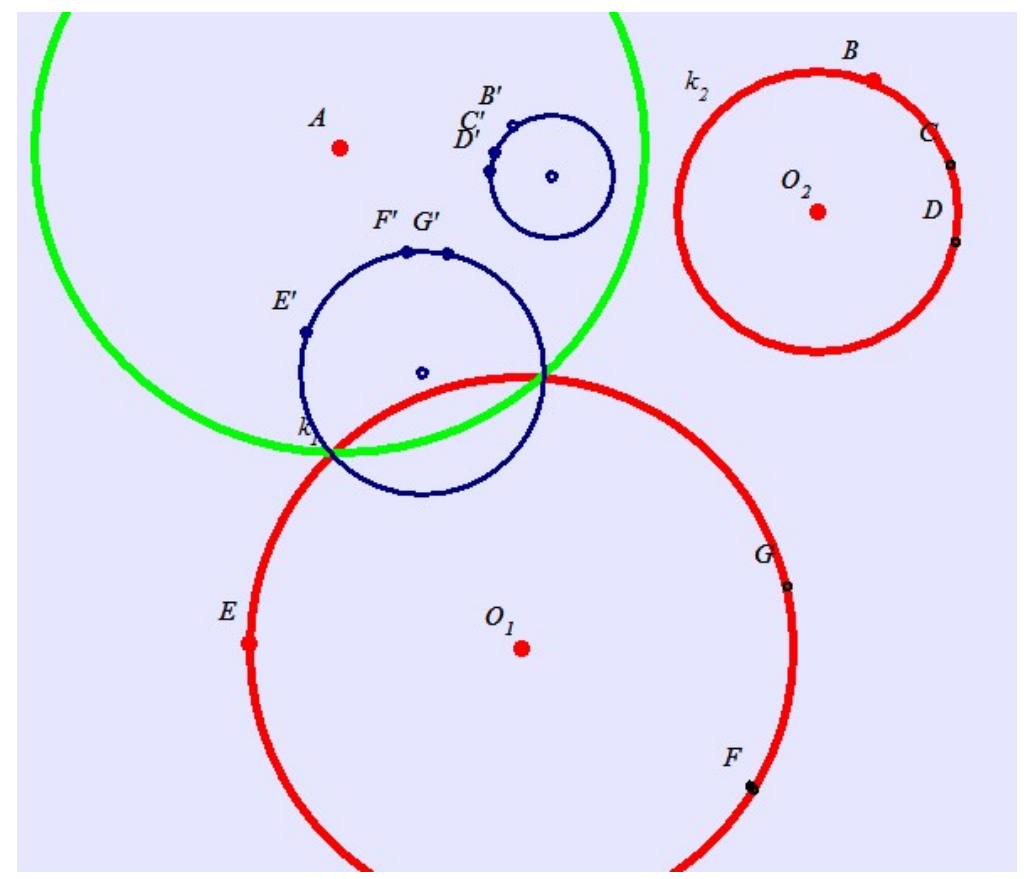


iii) common tangents

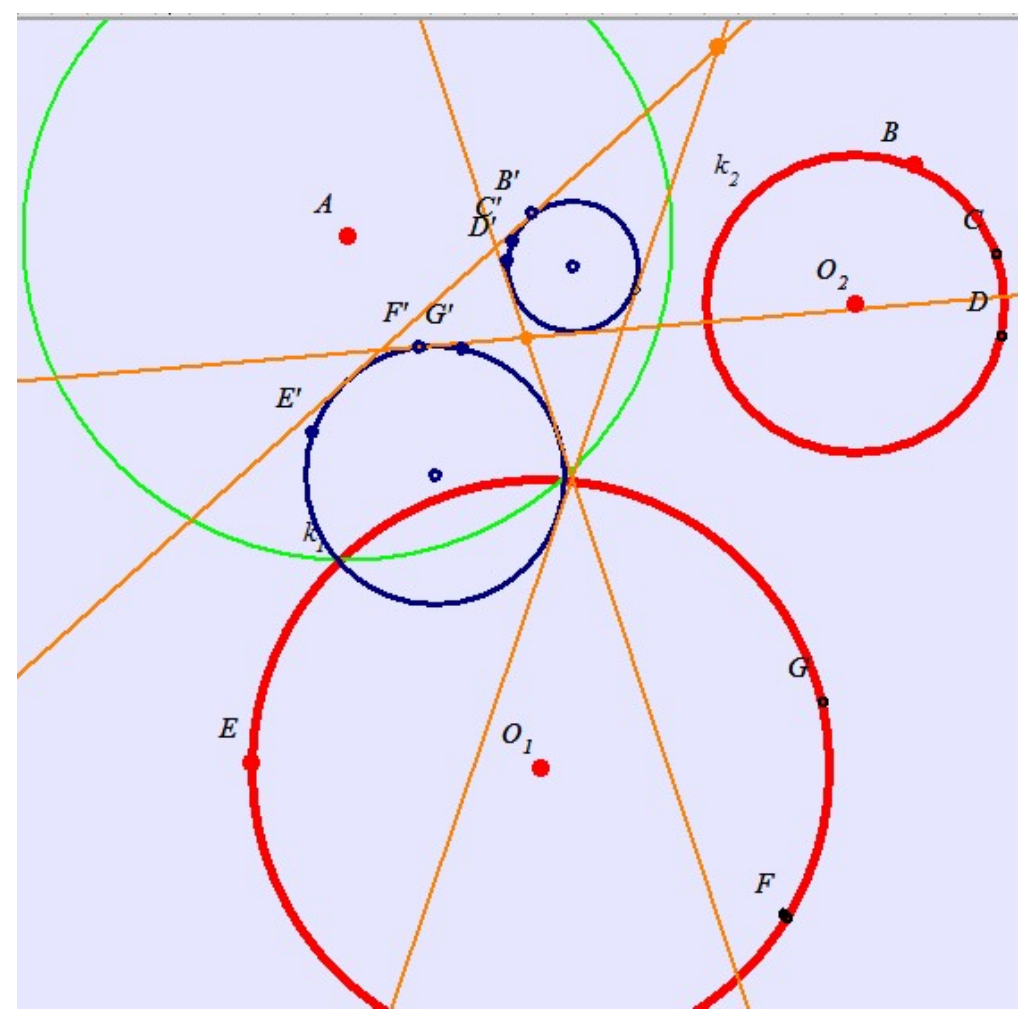

iv) inversion back

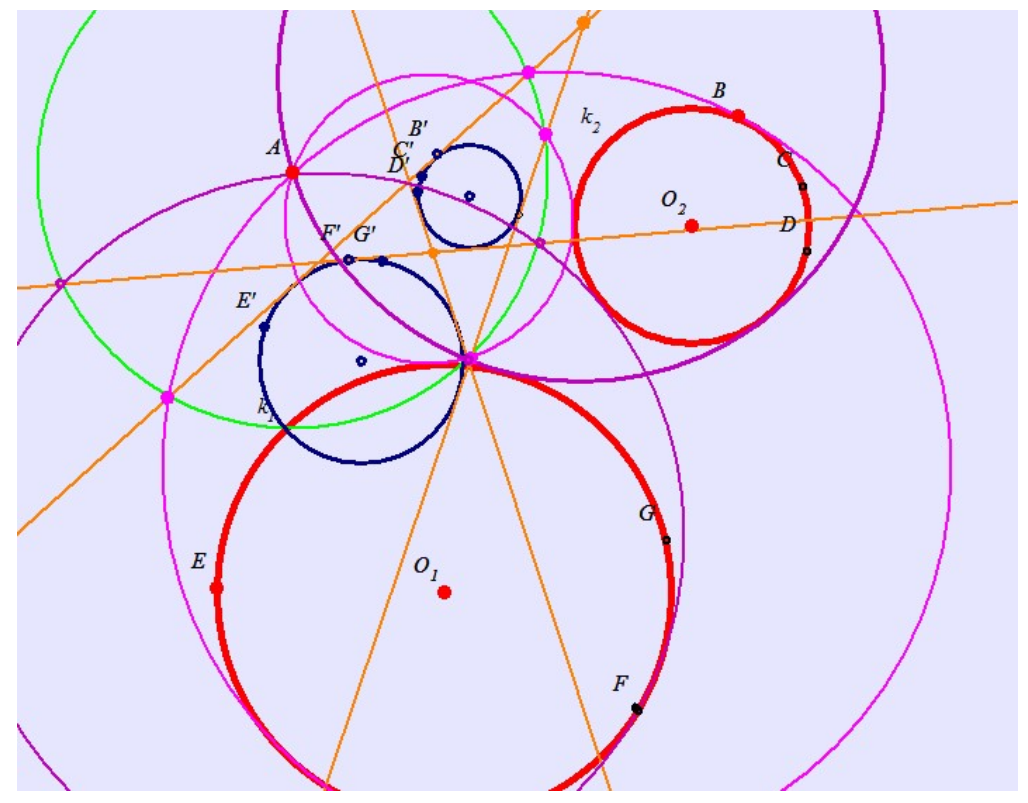


v) four solutions

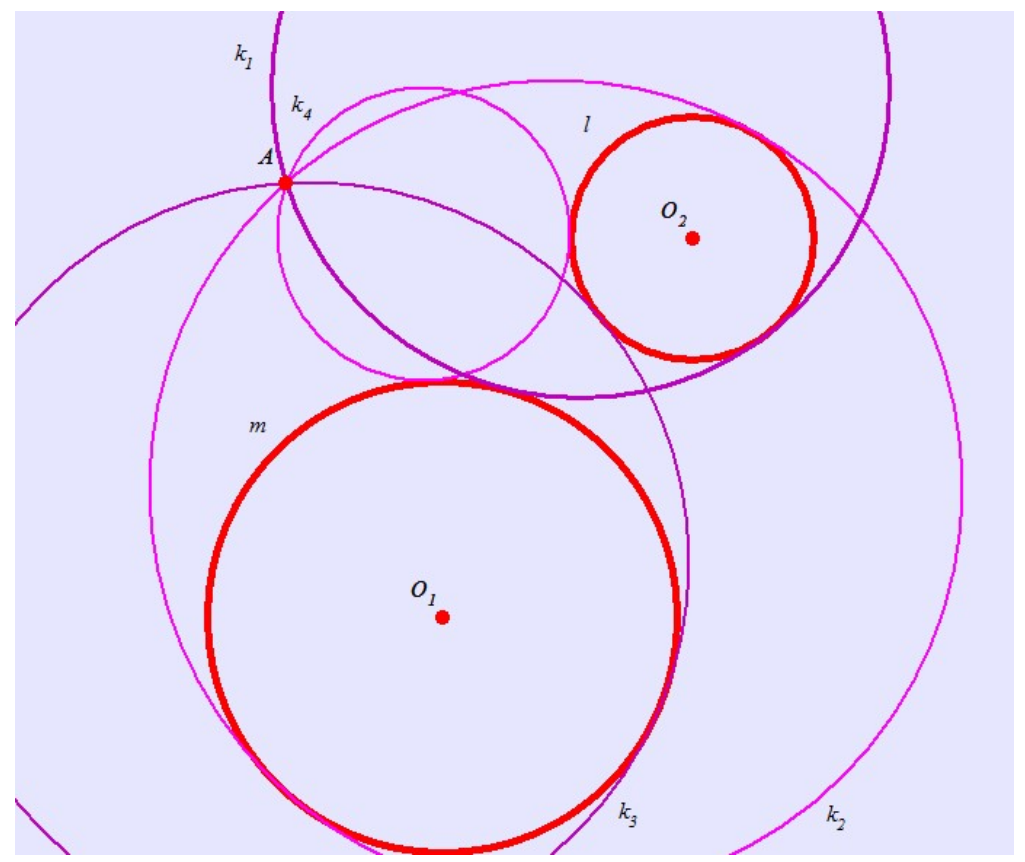

Discussion: If point $A$ is neither on circle $l$ nor on circle $m$, there are four solutions to that problem, because in this inversion $\psi_{i}(A, r)$ images of the circles are circles, so two circles without common points have four common tangents, two inside and two outside of circles $l^{\prime}$ and $m^{\prime}$.

\section{THE CIRCLE TOUCHES THREE GIVEN LINES $p, q, r$}

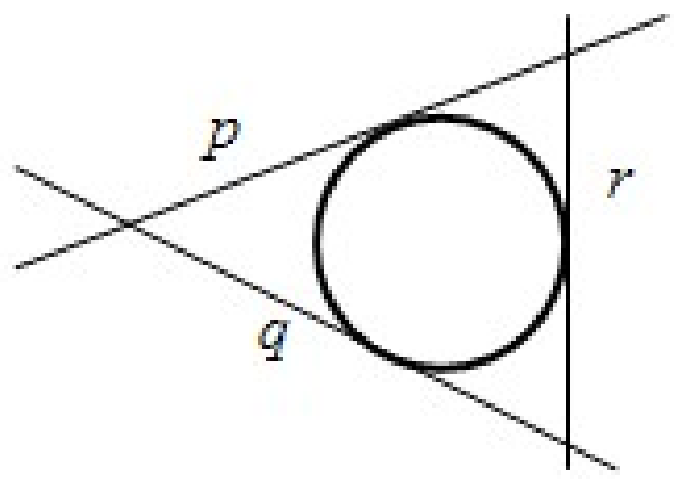

Solution: The solution is the inscribed circle of the triangle if the lines have intersection points in pairs.

Discussion: i) If given lines $p, q, r$ form a triangle, the center of this circle is the intersection point of bisectors of this triangle. But there are three circles outside of the triangle. 


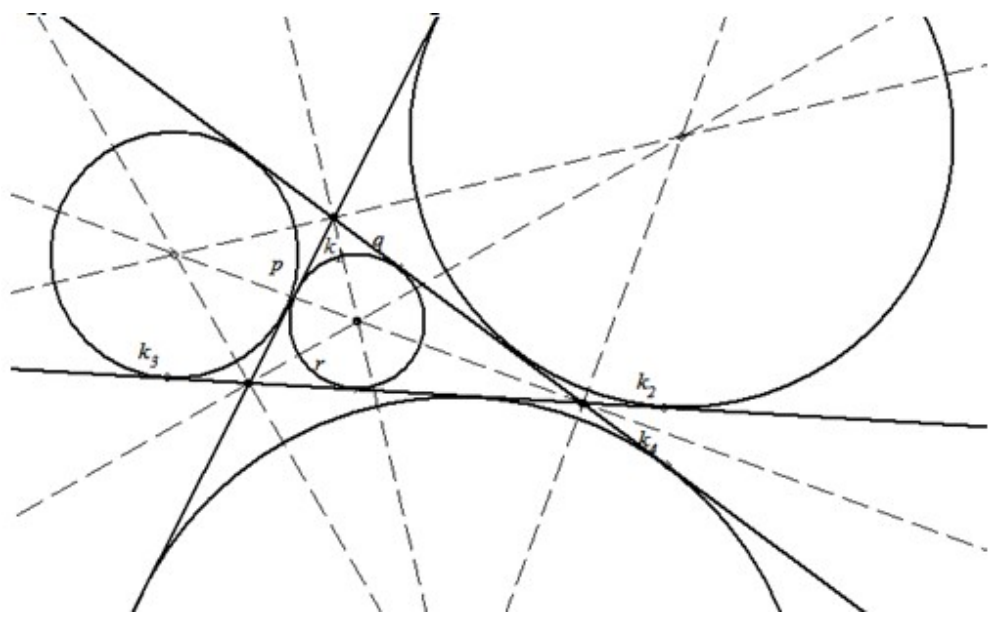

ii) If two lines are parallel and the third line intersects both given lines, there are two circles.
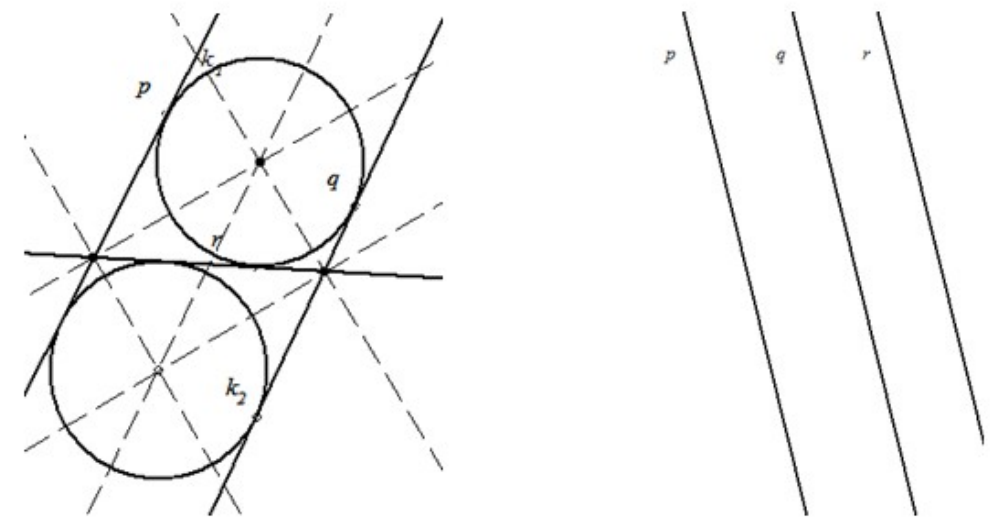

iii) If all three lines are parallel, then there isn't any solution of the problem. 
8. THE CIRCLE TOUCHES TWO GIVEN LINES $p, q$

AND THE GIVEN CIRCLE $l$

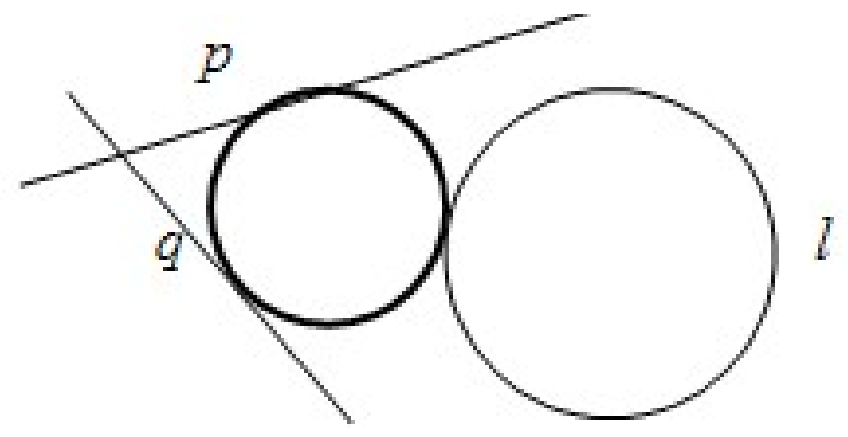

Solution: Every circle which touches two lines $p$ and $q$ has a center on the symmetry line of these lines.

(a) Reduce the given circle $l(O, r)$ to a point $O$, center of the circle,

(b) decrease the radius $r$ to zero,

(c) construct lines $p^{\prime}$ and $q^{\prime}$ parallel to given lines on the difference $r$ from given lines

(d) use the solution of the problem 4 .

After finding this circle, increase its radius with $r$. As in the fourth problem, two solutions exists here as well.

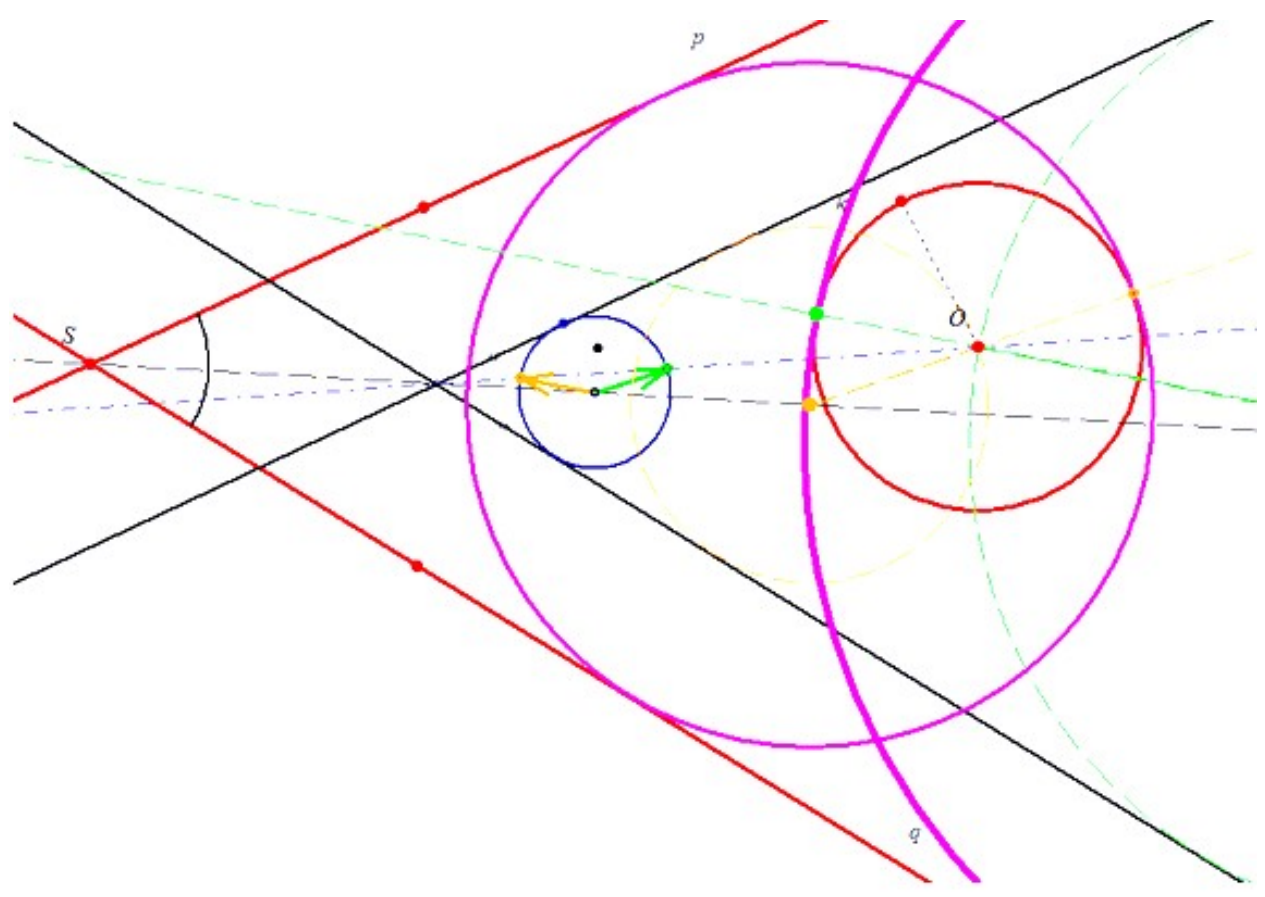


9. THE CIRCLE TOUCHES THE GIVEN LINE $p$

AND TWO GIVEN CIRCLES $l, m$

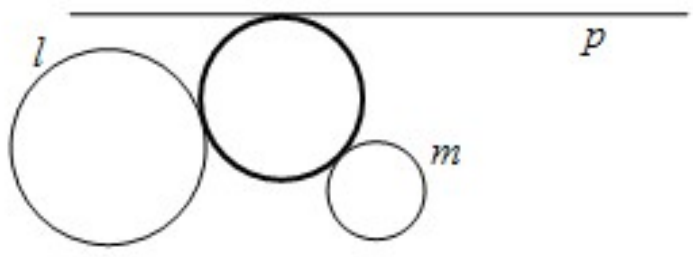

Solution:Let $l\left(O, r_{1}\right)$ and $m\left(S, r_{2}\right)$ be the given circles and let $r_{1}<r_{2}$. Then reduce circle $l$ to a point $O$, and reduce circle $m$ 's radius $r_{2}$ with $r_{1}$. Now this problem is the same as the fifth problem. Construct the circle as a solution, and increase its radius with $r_{1}$.

Discussion: If the given circles and the line do not have an intersection point, there are six possible solutions to the problem.[3]
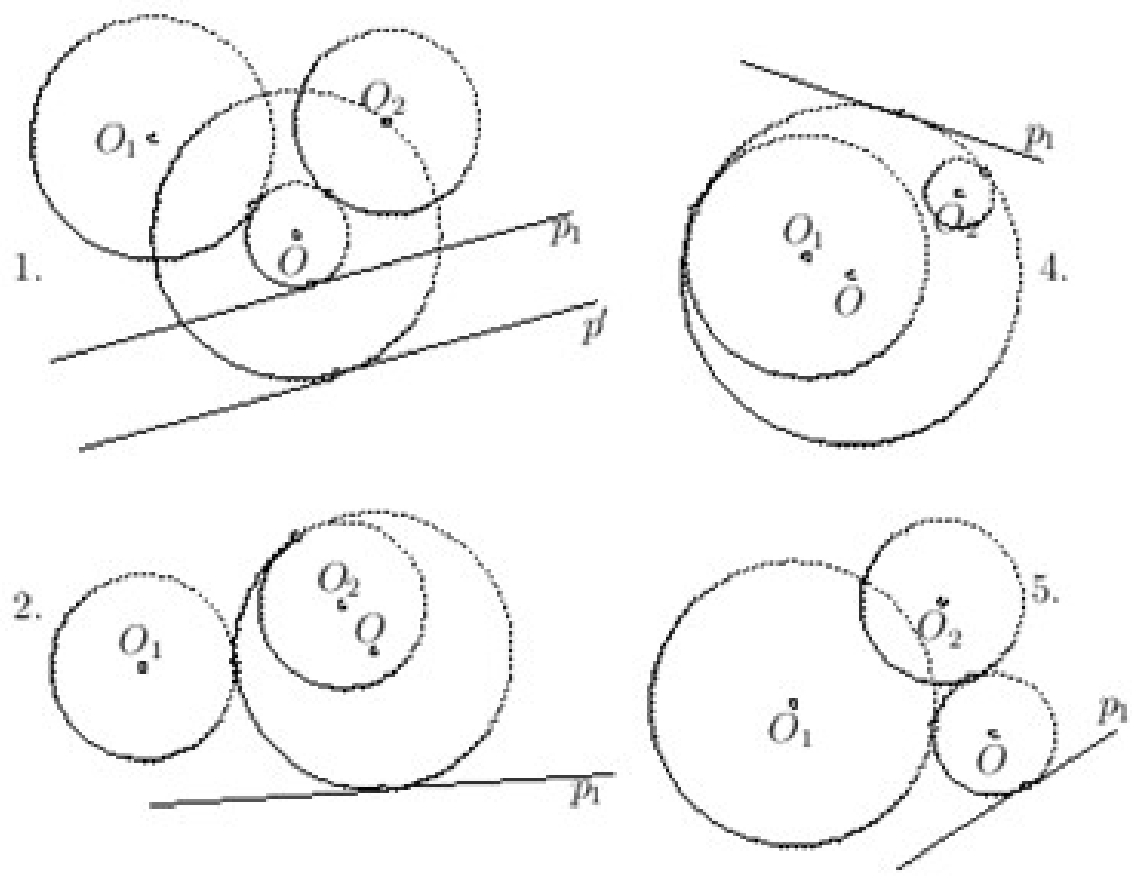

3 .
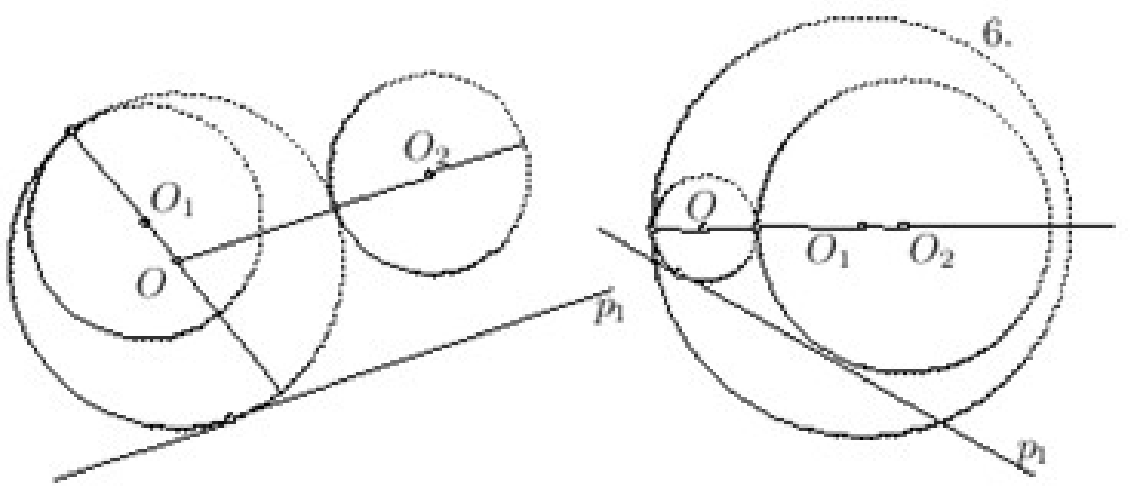
10. THE CIRCLE TOUCHES THREE GIVEN CIRCLES $l, m, n$

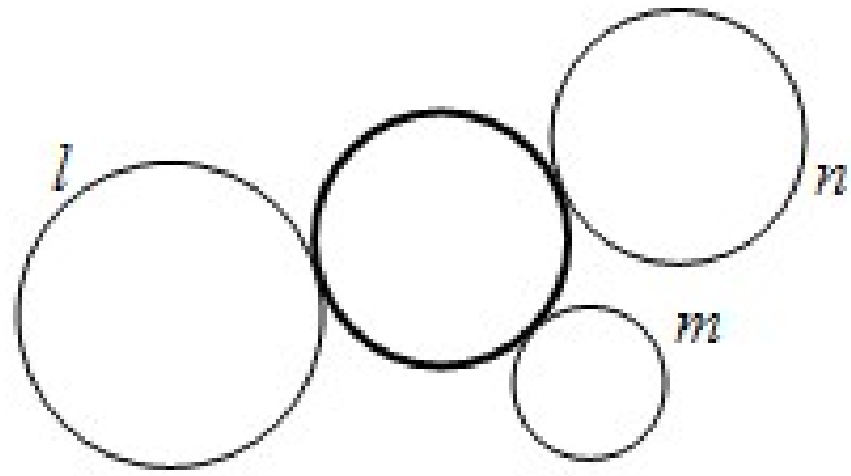

Solution: This problem was the first and the most interesting of Apollonius' problems, and later gave formulation to all of them. Let $m\left(O_{1}, r_{1}\right)$ be the smallest circle. Reducing it to the point $O_{1}$, decrease its radius to zero, and decrease the radiuses $r_{2}$ and $r_{3}$ of circles $l\left(O_{2}, r_{2}\right)$ and $n\left(O_{3}, r_{3}\right)$ by $r_{1}$. Now it has become the sixth problem with one point and two given circles. Find and construct the circle as the solution and increase its radius by $r_{1}$.
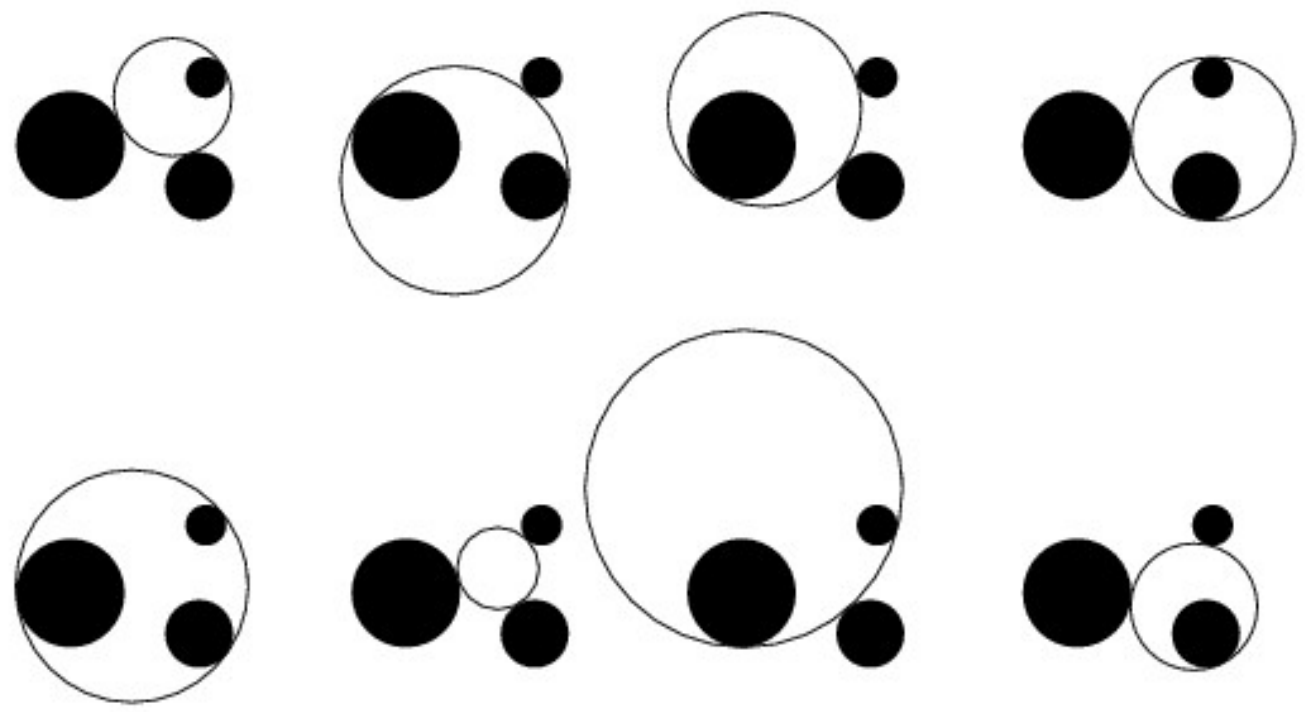

Discussion: If these circles do not have common point, one can get everyone of the eight possible solutions, as above [36]. 
At the end of the school year my students are able to construct these geometry problems using compass and rulers on paper using technical pencil. Two are from five lessons in computer laboratories to help students understand, experiment and learn the basics of the problems. The remaining three lessons are classical constructions to develop the students' psychomotorical skills. Psychomotorical aims of teaching geometry are in [1]:

- grasping the clear solutions of the tasks;

- smart and clever use of compass and rulers;

- free sketching;

- making mathematical and geometric models of the problem;

- using computers and calculators.

These targets are satisfied during the 144 Geometry I lessons of the year. Students have to construct the fifth and/or the sixth Apollonius' problem as homework. Marks are based on the following classification:

precise construction, nice drawing excellent (5)

one little error very good (4)

two or three inaccuracies good (3)

incorrect drawing sufficient (2)

not worked insufficient (1)

The results, the dispersion of the points in the constructions of the fifth (or sixth) Apollonius' problem in three groups are shown in the table below, where generations are noted vertically in green color, and the marks are noted horizontally in red color:

\begin{tabular}{|c|c|c|c|c|c|c|}
\hline & & 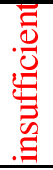 & 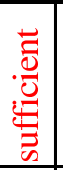 & $\begin{array}{l}\overrightarrow{8} \\
8 \\
0.0\end{array}$ & $\begin{array}{l}\overrightarrow{8} \\
8 \\
00 \\
2 \\
\overrightarrow{0} \\
>\end{array}$ & 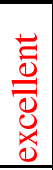 \\
\hline & & 1 & 2 & 3 & 4 & 5 \\
\hline 2008 & 20 students & 1 & 3 & 4 & 2 & 10 \\
\hline 2009 & 26 students & 2 & 3 & 3 & 3 & 15 \\
\hline 2010 & 22 students & 2 & 2 & 1 & 3 & 14 \\
\hline summary & 68 students & 5 & 8 & 8 & 8 & 39 \\
\hline
\end{tabular}

Every year students produce very nice, precise constructions, here is one image of the best works made by P.M. of the sixth problem, $\left(A, k_{1}, k_{2}\right)$ given a point and two circles. 


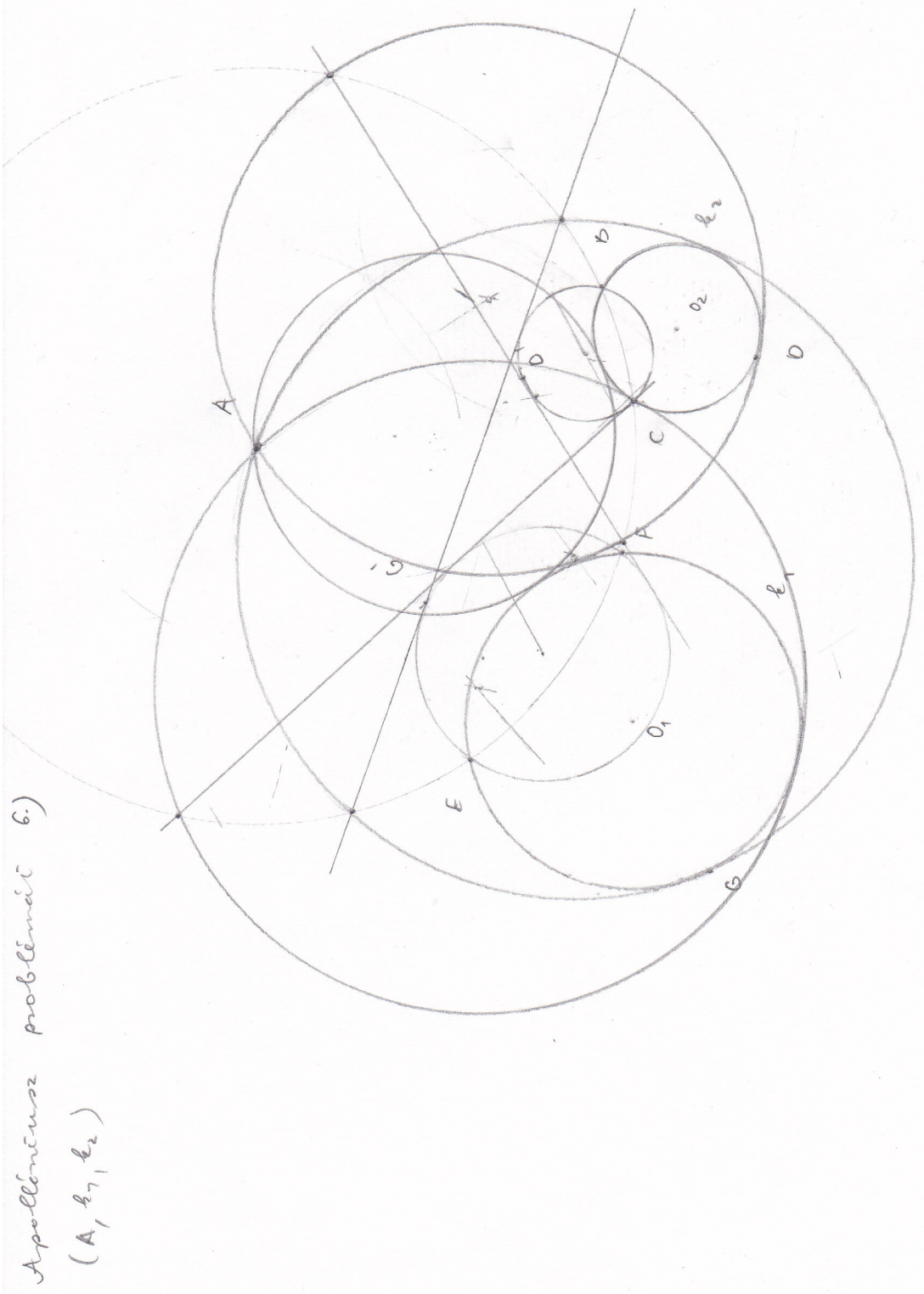




\section{Is there geometry after Euclid?}

During three years of learning Geometry, high school students can get to know various geometric axiom systems to develop their divergent and critical thinking skills, as Munkácsy Katalin writes in [17] :

"Students should know that Geometry (and generally Mathematics) is not a natural science in classical terms. They have to know that we can't guarantee that mathematical theorems which have been proven are surely true, but still, they have been working well in past millenniums."

During the introduction and study of Hilbert's axioms, we become acquainted with the fact that there are 21 assumptions that underline the geometry published in Hilbert's classic text "Grundlagen der Geometrie" [11]: the incidence axioms, ordering axioms, congruence axioms, continuity axioms and the single parallel axiom equivalent to Euclid's fifth (parallel) postulate, as we can read in Euclid's "The Elements" [9]. But it is our mission, the teacher's duty today, to show the different possibilities of this axiom of parallels.

At this point, the three basic axiom-systems of parallel lines are presented by:

1. Playfair's axiom - one parallel line

2. Lobachevsky-Bolyai's axiom - two or more parallel lines

3. Riemann's axiom - no parallel lines,

But projective geometry is also introduced, by Desargues' and Pappus' theorems [7].

"In Euclidean geometry, constructions are made with ruler and compass. Projective geometry is simpler: its constructions require only a ruler. In projective geometry one never measures anything, instead, one relates one set of points to another by a projectivity [8]."

There are three main classes of constant curvature geometries in three dimensions.

All theories are based on the first four of Euclid's postulates, but each uses its own version of the parallel postulate. The "flat" geometry of everyday intuition is called Euclidean geometry (or parabolic geometry), and non-Euclidean geometry is called hyperbolic geometry (or Lobachevsky-Bolyai-Gauss geometry in the Scientiam Spatii [4]) and elliptic geometry (or Riemannian geometry). Spherical geometry is a non-Euclidean two-dimensional geometry. 


\subsection{Hyperbolic geometry}

The axiom of parallels (Bolyai-Lobachevsky) in the hyperbolic geometry is:

In the hyperbolic model, within a two-dimensional plane, for any given line $l$ and a point $A$, which is not on line $l$, there are infinitely many lines through point $A$ that do not intersect line $l$.

János Bolyai used pseudosphere as a model of the new geometry he had discovered, but later some other models of hyperbolic geometry were created:

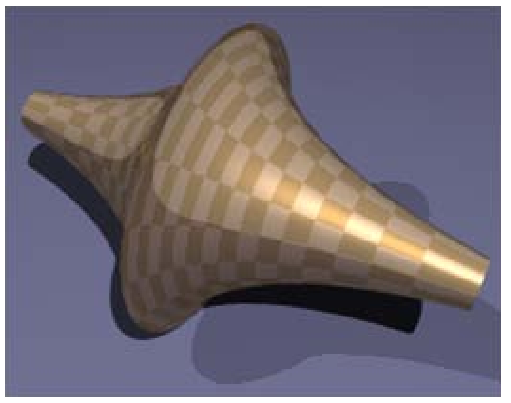

1. The Cayley-Klein model

2. The Poincaré Disk Model

3. The Poincaré Half Plane Model

4. The Hemisphere Model

On Euclid's plane and space there are many kinds of structures, but we must redefine words like point, line, distance, and angle in order to have a surface in which the parallel postulate fails, but which still satisfies Euclid's first four postulates. The models have enormous significance in the relative consistency proofs. If Euclid's postulates are consistent then these models are too, and this proves that the hyperbolic plane is possible, because the fifth axiom does not come from the others.

\section{The Cayley-Klein model}

In the Klein model of the hyperbolic plane, the "plane" is the unit disk; in other words, the interior of the Euclidean unit circle. We call Euclidean points the "points" for our model. We call the portions of Euclidean lines which intersect the disk "lines".

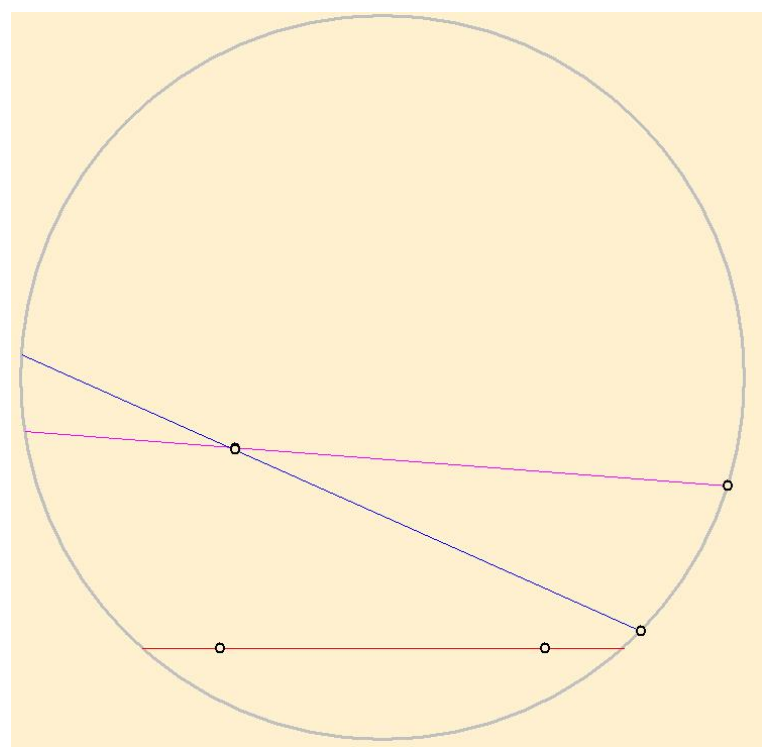




\section{The Poincaré Disk Model}

In this model, the "plane" is the unit disk, and the "points" are Euclidean points. "Lines" are portions of circles intersecting the disk and meeting the boundary at right angles. This is a very easy task after learning inversion, because students are able to construct the perpendicular circles to the given circle across the given two points $A$ and $B$.

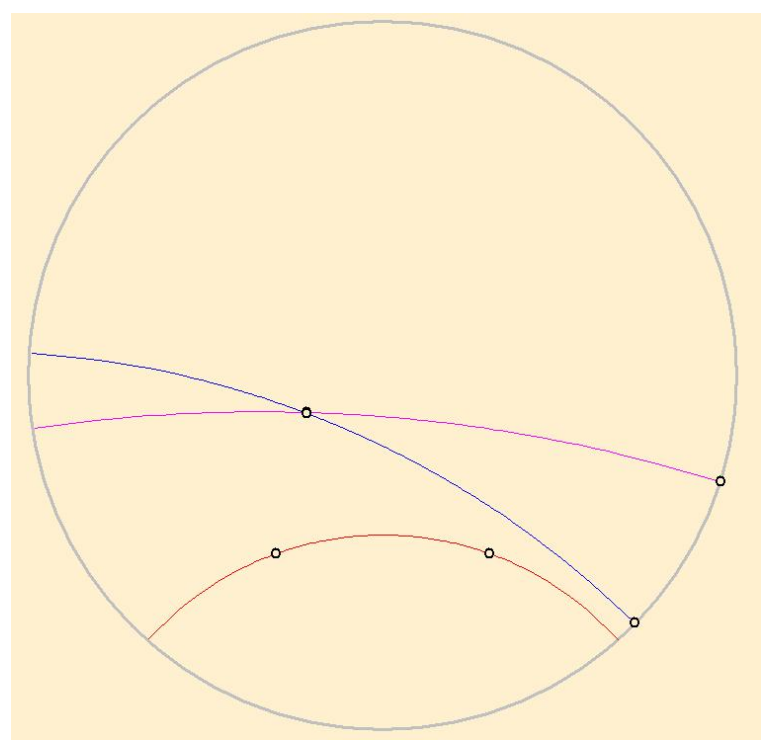

\section{The Poincaré Half Plane Model}

From the disk model we can create other models with inversion. If we choose a point $P$ on the base circle and we apply the inversion with the $P$ pole, then the image of the circle is going to be a line, the image of its interior is a half plane. Those lines whose one endpoint was $P$ are going to be normal lines with the boundary line. The other lines are going to be half circles.
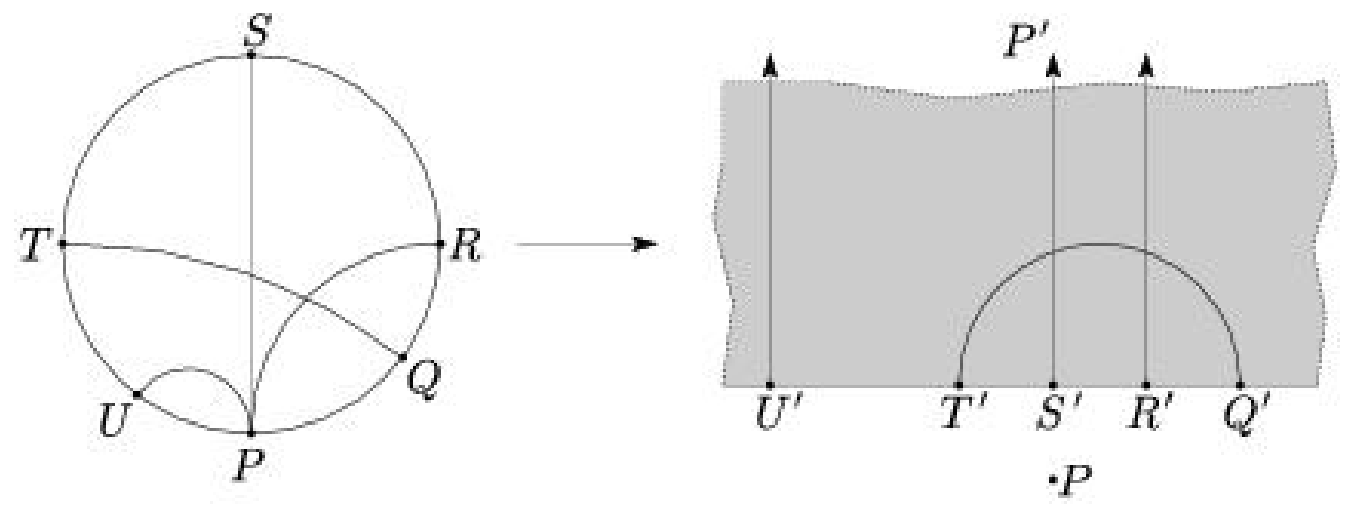


\section{The Hemisphere Model}

If we don't choose the inversion's point from the same plane, but from another plane then the model becomes a calotte or a hemisphere. In this kind of model the points are in the interior of the hemisphere's surface. The lines are the normal half circles with the boundary. The angles are the same as in the Euclidean plane.

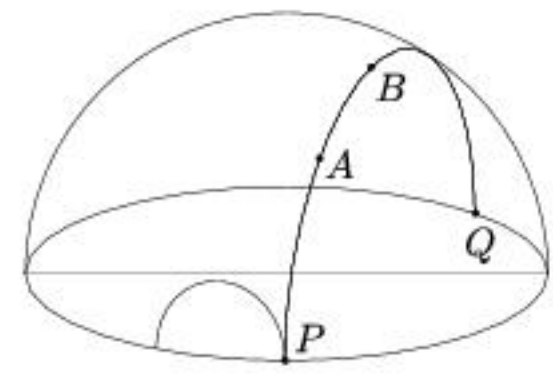

The first and the second models are examined at the grammar school. We use the "Bolyai.exe" software written by Szilassi Lajos [27], for experimenting with hyperbolic geometry. This software has options to switch between the Cayley-Klein model and the Poincaré-model, too.

This way students can understand the concept of the "line" and discover, to their great surprise, two or more parallels to the given "line". The concept of infinity, that the boundary of the main circle in the Poincaré-model is not in "our world", is very important. Sometimes students find demonstrations on the internet, like this one from "WolframResearch":

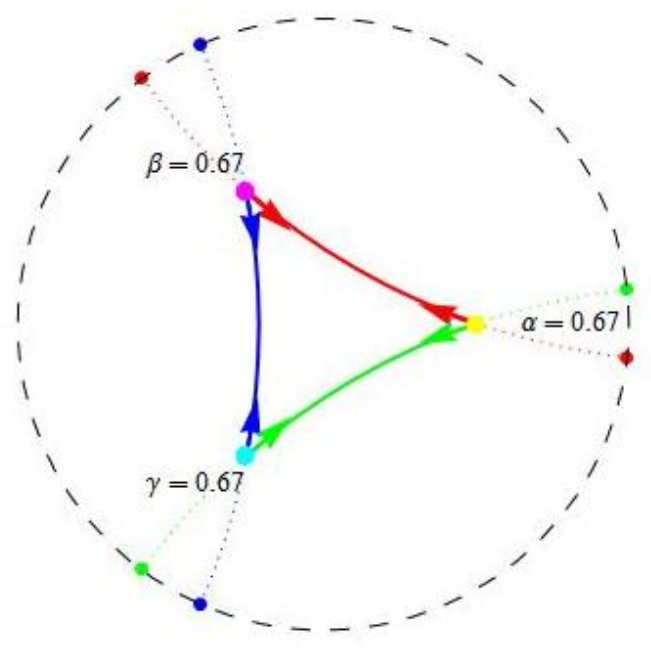

Students usually construct some triangles in this Poincaré-model, to find a sum of the angles of the triangle and calculate the defect of the triangle. They understand that the Lobachevsky-Bolyai's axiom is equivalent with the statement that the sum of the angles in the triangle is less than a straight angle. The special case of the triangle with zero sums of the angles is always found to be amazing. I always take a tour to astronomy and tell them the true story about Albert Einstein's "Theory of General Relativity", that in May, 1919, a team led by a British astronomer, Arthur Stanley Eddington, claimed to have confirmed Einstein's prediction of gravitational deflection of starlight by the Sun while photographing a solar eclipse on the island of Principe near Africa [35]: 
"The perihelion precession of Mercury was the first evidence supporting the fact that general relativity is correct. Sir Arthur Stanley Eddington's 1919 expedition in which he confirmed Einstein's prediction for the deflection of light by the Sun helped to affirm the status of general relativity as a likely true theory. Since then, many observations have confirmed the correctness of general relativity. These include studies of binary pulsars, observations of radio signals passing the limb of the Sun, and even the GPS system."

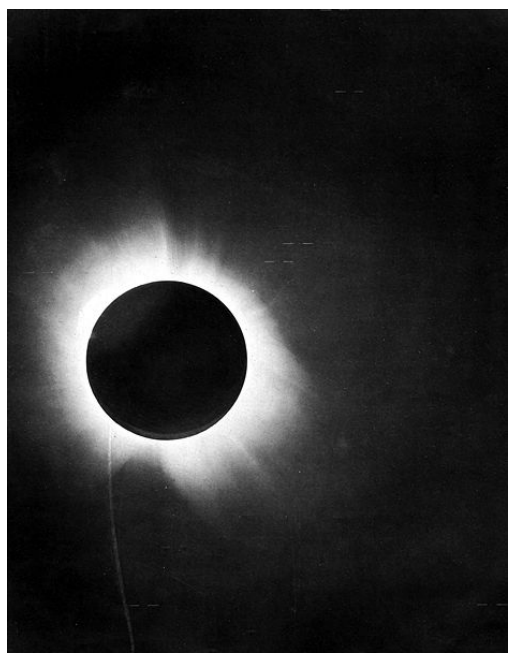

One of Eddington's photographs of the total solar eclipse of 29 May 1919, presented in his 1920 paper announcing its success, confirming Einstein's theory that light "bends".

I usually show them a picture from Sir Arthur Eddington's report on the expedition to verify Albert Einstein's prediction of the bending of light around the Sun, the great center of gravity. This is a real model of non-Euclidean geometry in nature.

The hyperbolic tiling is an homage to Coxeter's book [7], that is a great collection of symmetries and interesting geometry problems to teach gifted students.

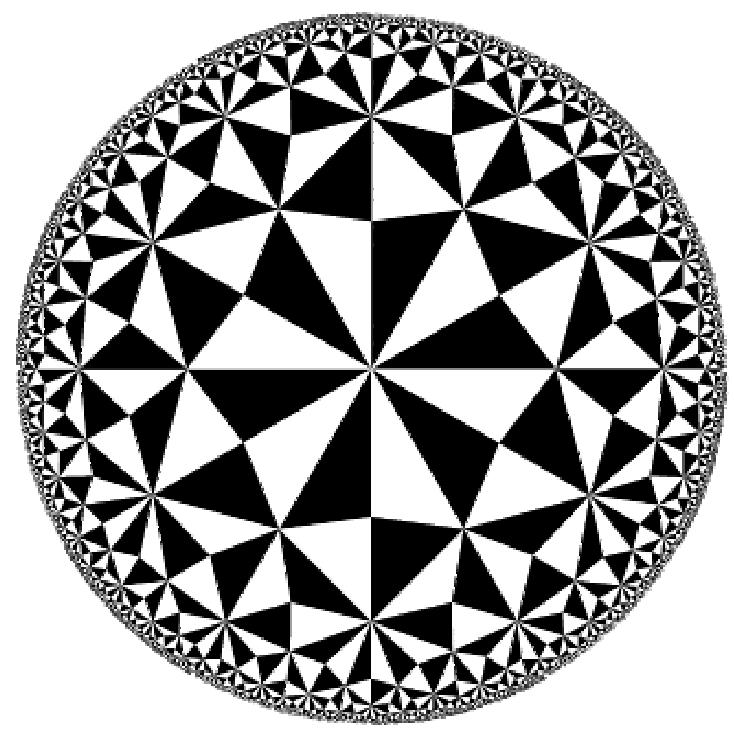




\subsection{Spherical geometry}

Spherical geometry is non-Euclidean, two-dimensional geometry.

The axiom of parallels in the elliptic model is:

For any given line $l$ and a point $A$, which is not on line $l$, all lines through point $A$ will intersect line $l$.

It is not an easy task to understand this axiom, although students already know the geographical lines on the Earth. I use the Lénárt Sphere kit to study spherical geometry [13], and to light up and understand the essence of it. Our school has seven sets of these Lénárt Sphere since the "Bolyai Farkas Foundation" donated them to us. This tool is very useful and my students like it. These geometry construction materials allow primary and secondary school students to investigate spherical geometry using a real sphere and the spherical equivalents of a compass and ruler. With these new tools, students can compare and contrast relationships between the points and the lines on the sphere with the corresponding relationships between the points and the lines in Euclidean geometry. Working with non-Euclidean geometry keeps students' thinking fresh and deepens their insight into planar geometry. Investigating spherical geometry requires students to think creatively. Hands-on work with the Lénárt Sphere is a great opportunity for students to increase their spatial visualization skills.

\section{Spherical sine and cosine law}

On the sphere there are special forms of the laws of sines and cosines.

Theorem 7.1. Let $\triangle A B C$ be a spherical triangle with sides $a, b, c$ and angles $\alpha, \beta$ and $\gamma$, then the formulas are

$$
\begin{gathered}
\cos a=\cos b \cdot \cos c+\sin b \cdot \sin c \cdot \cos \alpha \\
\cos \alpha=-\cos \beta \cdot \cos \gamma+\sin \beta \cdot \sin \gamma \cdot \cos a \\
\quad \frac{\sin a}{\sin \alpha}=\frac{\sin b}{\sin \beta}=\frac{\sin c}{\sin \gamma} .
\end{gathered}
$$

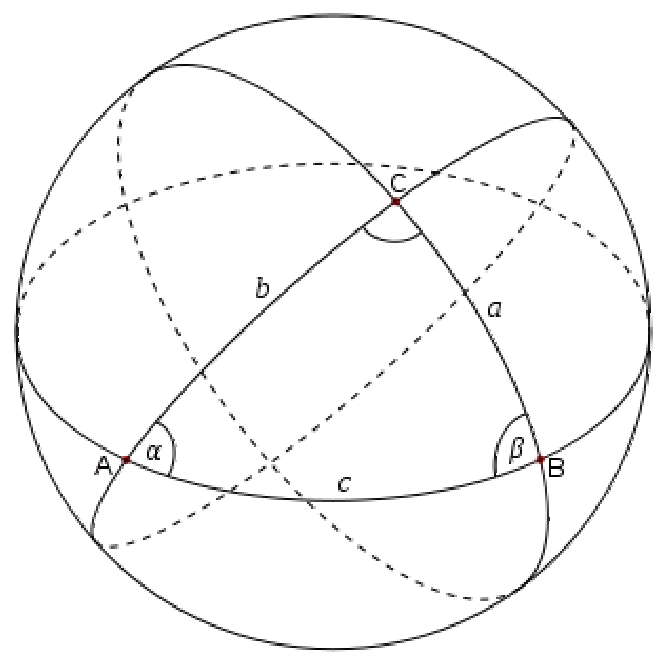


Every generation from 2006 can experiment on the Lénárt Sphere. Our school has six complete sets, to draw spherical triangles to measure their sides and angles. It is very exciting for the students that the sides of the triangle are measured in degrees (or radians). The axioms are given first. What is a line in the plane and on the sphere? What is a segment?

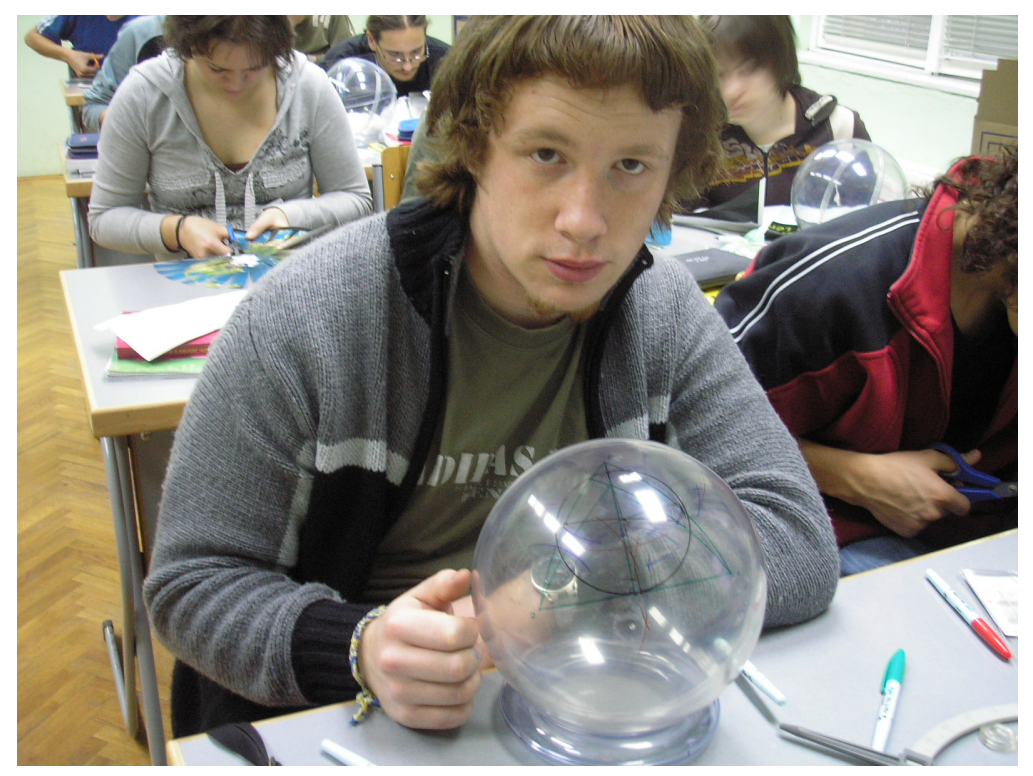

They draw a segment on the sphere, construct two angles, and then extend two other sides to their point of intersection. Now students can measure and calculate the length of these "segments" on the sphere. This Lénárt Sphere is a very useful tool, students enjoy it, they like every experiment, they color and construct and measure segments on the sphere using a "spherical ruler" and a "spherical compass" with great enthusiasm, although formulas are complicated.

\section{Task for assessment and evaluation}

After two weeks, eight lessons of experimentation on the Lénárt Sphere and calculating the elements of the spherical triangles, there was the task for assessment by solving, calculating and constructing the spherical triangle

$$
\begin{aligned}
& a=74^{\circ} 45^{\prime} \\
& b=112^{\circ} 40^{\prime} \\
& \gamma=22^{\circ} 37^{\prime}
\end{aligned}
$$

The task was to draw model and calculate the missing elements of the triangle.

The good results with adequate precision of a minute are:

$$
\begin{gathered}
c=43^{\circ} 54^{\prime} \\
\alpha=32^{\circ} 20^{\prime} \\
\beta=149^{\circ} 13^{\prime}
\end{gathered}
$$

Here are some solutions with graphical drawings of spherical triangles: 
- excellent work by P.I., with precise calculations, and a good picture of a spherical triangle. He used cosines to the third angle and he could not make mistakes because the sign of the cosines of the angle showed that the angle was acute or obtuse.

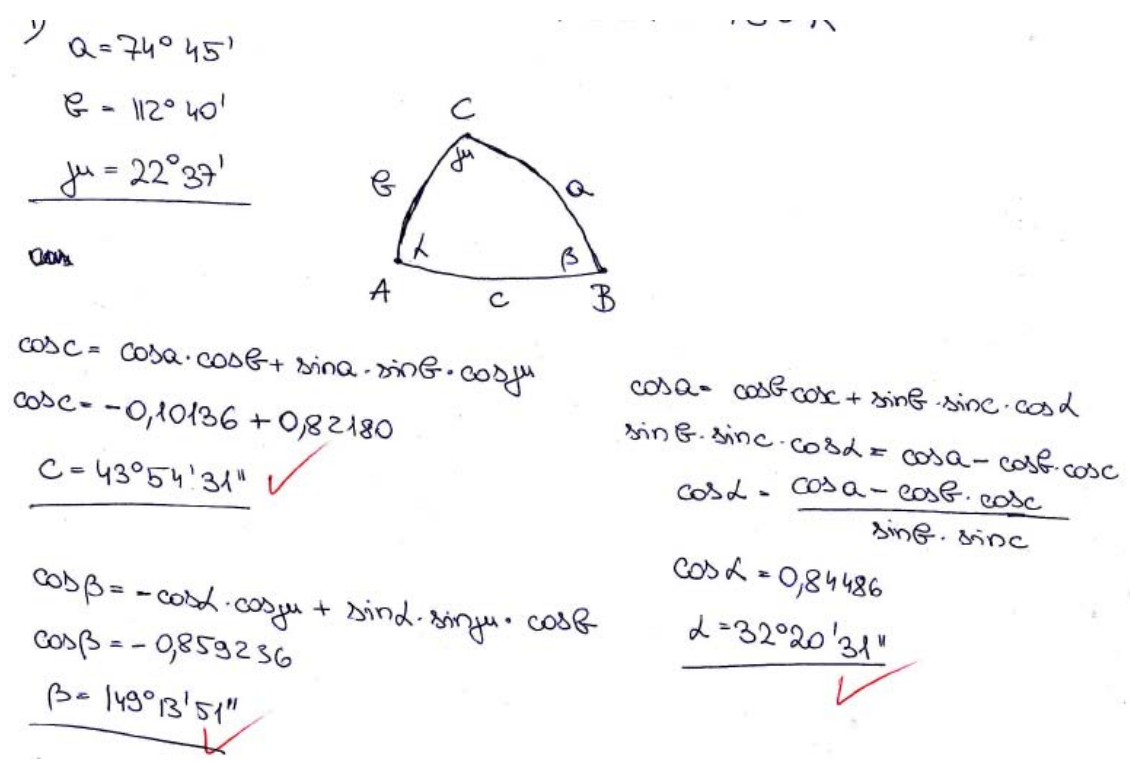

- good work made by P.A., who is our best little mathematician in the second grade of the grammar school. She made a little mistake, while she was calculating the third angle. She used the sine law, and there were two results: acute and obtuse angles. She chose the wrong one, although she knew that the sum of the angles of spherical triangle was greater then the straight (flat) angle. During the next lesson I asked her what kind of triangles had a sum of angles less than the straight angle, and she knew the correct answer, in hyperbolic geometry. (She remembered the experiment in hyperbolic geometry, when she had measured the angles of special triangles.)

$$
\begin{aligned}
& \text { Pin Annamdrie } \quad \cos c=\cos a \cos b+\sin a \sin b \cdot \cos 0 \\
& \text { 1. } a=74^{\circ} 45^{-1} \\
& b=112^{\circ} 40^{\prime} \\
& \gamma=22^{\circ} 37^{\prime}
\end{aligned}
$$

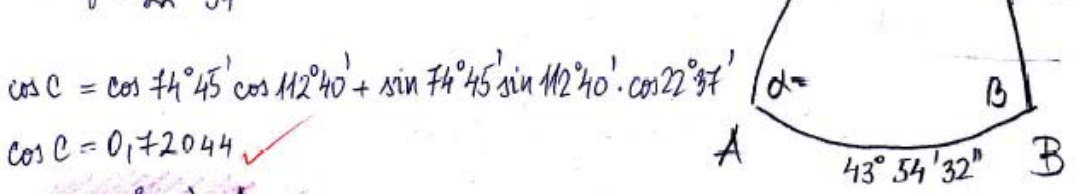

$$
\begin{aligned}
& C=43^{\circ} 54^{\prime} 32^{\prime \prime} \mathrm{V} \\
& \sin a: \sin \alpha=\sin \alpha: \sin \gamma \\
& \sin \alpha=\frac{\sin a \cdot \sin \gamma}{\sin C}=0,534988 \\
& \alpha=32^{\circ} 20^{\prime} \\
& \sin \beta=\frac{\sin b \cdot \sin \gamma}{\sin C}=0,51168 \\
& \beta=30^{\circ} 46^{\prime} 34^{\prime}
\end{aligned}
$$

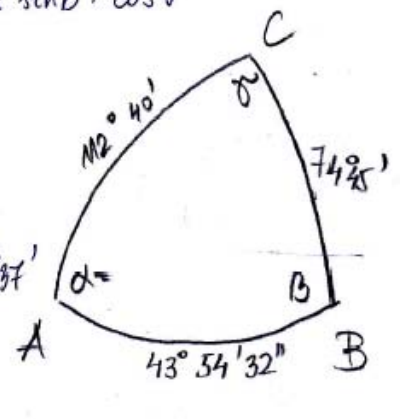


- interesting work by M.O., who couldn't believe that the sum of the angles of the spherical triangle was grater than the straight (flat) angle, although she knew the theorem, but the well-known Euclidean theorem was "stronger" in her mind. She calculated well but after she crossed out the good answer, the correct result. Naturally on the next lesson of geometry she had an opportunity to construct the given triangle on the Lénárt Sphere, to check her results.

1.)

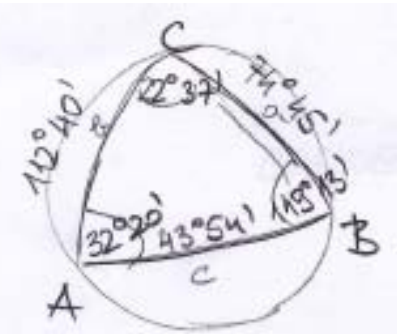

$$
\begin{aligned}
& a=74(45)-\sin a+0,964787323 \\
& b=\left(12^{\circ} 40^{\prime} \text { ) cost } \text { rive } 0,0,322762444\right. \\
& V=22^{\circ} 37^{\prime} \text { ro, } 923098391 \\
& c=43^{\circ} 54^{1 / 1} \cos c-972 \text { on } 421 \\
& C=43^{\circ} 54^{\prime} \text { tinc }=9693515089
\end{aligned}
$$

$$
\begin{aligned}
& \cos c=\cos a \cdot \cos b+\sin a \cdot \sin b \cdot \cos \gamma \quad 0,82180635 \\
& \cos c=9283031214 \cdot(-0,38536966)+9,964787323 \cdot 9,922762444 \cdot(+0,923098391) \\
& -0,101364249
\end{aligned}
$$

$\cos C=0,7204421$

$$
c=43^{\circ}\left(4^{\prime}\right.
$$

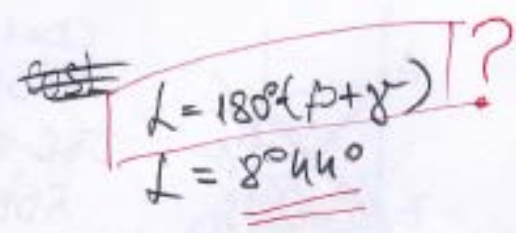

\section{$\cos \alpha=-\cos$}

$\cos b=\cos a \cdot \cos c+\sin a \cdot \sin c \cdot \cos \beta$

$$
\cos \beta=\frac{\cos b \cdot \cos a \cdot \cos c}{\sin a \cdot \sin c}
$$

$-0,189527$

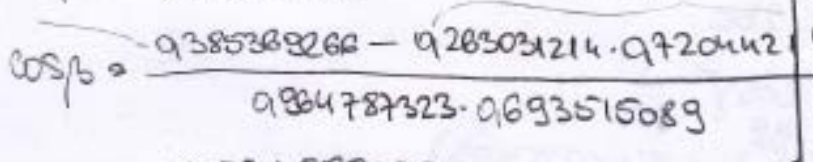

$\cos \beta=\frac{-9574889639}{9.669094566}$

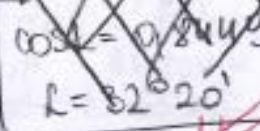

$\cos \beta=:-9859205362$

$$
b=149^{\circ} 13^{\prime}
$$


- beautiful drawing was made by V.D., with a sphere and a triangle on it, but he made a little mistake in the calculation.

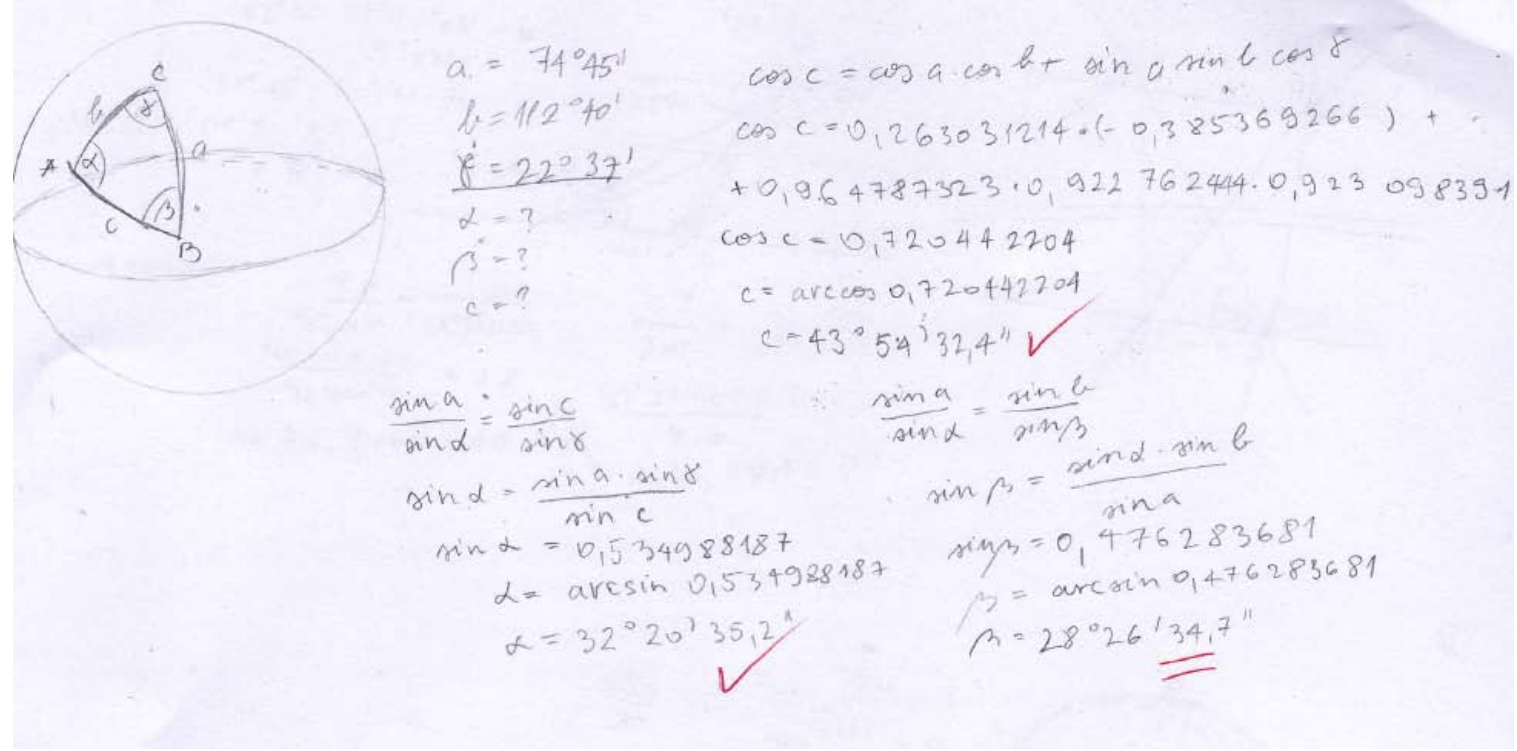

- lost in space, M.H. drew a picture of a hyperbolic triangle, and of course she was not upset when the sum of the angles of the triangle came to less than the straight angle. They learned about Poincaré's model of non-Euclidean space made by Bolyai, and she lost herself in the spaces. That is very interesting when in exciting moments one can loose the space where he/she is working.

$$
\begin{aligned}
& 1 .
\end{aligned}
$$

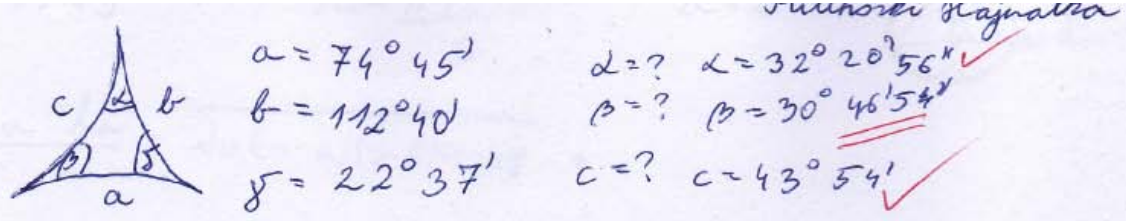

$$
\begin{aligned}
& \cos c=\cos a \cdot \cos b+\sin b \cdot \sin b \cdot \cos p \\
& \cos c=\cos 74^{\circ} 45^{\prime} \cdot \cos 112^{\circ} 40^{\prime}+\sin 74^{\circ} 45^{\prime} \cdot \sin 112^{\circ} 40^{\prime} \cdot \cos 22^{\circ} 37^{\prime} \\
& \text { cosc } c=0,26303(0,38537)+0,96479 \cdot 0,92276 \cdot 0,923098=0,72044 \Rightarrow c=43^{\circ} 541 \\
& \frac{\sin c}{\sin \gamma}=\frac{\sin a}{\sin \alpha} \Rightarrow \sin \alpha=\frac{\sin \gamma \cdot \sin a}{\sin c}=0,53567 \Rightarrow \alpha=32^{\circ} 20^{\prime} 56^{\prime \prime} \\
& \frac{\sin c}{\sin \gamma}=\frac{\sin b}{\sin \beta} \Rightarrow \sin \beta-\frac{\sin \gamma \cdot \sin b}{\sin c}=0,51177 \Rightarrow \beta=30^{\circ} 46^{\prime} 54^{\prime \prime}
\end{aligned}
$$




\section{Summary and results}

In summary the test for assessment ended with good results, students made beautiful drawings, very impressive works and they made interesting mistakes. Their fantasy produced wonderful ideas.

\begin{tabular}{|c|c|c|}
\hline & students & percent \\
\hline Excellent work & 7 & 32 \\
Good drawing with a little mistake in one angle & 10 & 45 \\
Bad drawing but good calculation of two angles & 3 & 14 \\
Not done or many mistakes made & 2 & 9 \\
\hline
\end{tabular}

They did not make mistakes in the calculating of the sides of the triangle, because it was necessary to use the cosine law.

After the test, the next lesson of geometry was very interesting and exciting, because during this time students found out their drawing and calculating mistakes. We tried again to precisely calculate the part of the triangle and construct the triangle on the Lénárt Sphere. I hope it was a memorable lesson to remember forever.

Naturally, we mostly study the wonderful world of Euclidean plane geometry.

It is very important to develop the cognitive attitude of the students in Geometry I, to help the development of thinking skills, their sense of the space, and the approach to modern sciences. Fifteen years old students have undeveloped mathematical thinking; they do not use problem solving thinking because they do not have experience in solving such tasks. Geometry gives great help in carrying out given problems.

All men by nature desire knowledge.

Aristotle 


\section{Summary}

In the Bolyai Secondary Grammar School and Dormitory for Gifted Students in Senta I have worked as a geometry teacher since the beginning of the school's existence in 2003. My method, teaching geometry using visualizations on the computer has been applied since 2004. We use "Euklides" DGS ( Dynamic Geometry System) to help pupils in understanding the difficult problems and constructing the figure with given properties. The DGS on the computer draws figures with special accuracy and one can move basic elements on the figure and follow changes of the figure. This way one can find new connections and proof of a given problem. This increases the students' motivation. They like lessons much more in the computer laboratory classroom; they ask for and wait for it. I expect growth of achievement on the graduation exam. During the first six years of teaching geometry using computers my experience shows that our pupils at the end of their secondary education receive the kind of tools and knowledge which help them solve problems in their own way using special skills, and find new solutions to technical problems as engineering experts. They learn to apply computers and visualizations to their own problems far from the field of geometry and mathematics in every special case of life and their mind is open to new discoveries in the world.

\section{Introduction}

Teaching mathematics in a secondary school is a very difficult task.Its most interesting area is axiomatically built geometry [21].

Helping students to understand and learn new theorems in geometry is an exciting task from a teachers point of view. Some psychological and didactical surveys show that the acquisition and learning of geometry in secondary school is a very difficult task. This could be due to a lack of problem-solving skills or to the decreasing creativity of the students. Consequently, few schoolchildren get to know the amazing world of science of the Ancient Greek geometers'. The incompleteness and imperfectness of representations on paper and limited time available hinder the learning of axiomatically-based theoretical geometry. A great number of geometrical figures, their symmetries, perfectness and variety remain unknown for some students who have finished secondary school.

One of the most important tools for children in the $21^{\text {st }}$ Century is their companion, the computer. Children born after 2000 are called Digital Natives by Marc Prensky, while we, the others born in the $20^{\text {th }}$ Century are Digital Immigrants with methodical thinking. Applying the computer in the teaching and learning processes plays an important role. It is important how we introduce the computer during the course of teaching and learning from the aspect of the achievement of the cognitive processes. The appearance and rapid development of dynamic geometry systems (DGS) has brought rapid progress in the teaching of geometry.

The criteria to measure creative mathematical potential based on the Balka's formulation in my translation are the following: 
- Learning the use of computer visualization in GeoGebra or Euklides helps to formulate mathematical hypothesis about cause and effect in mathematical situation.

- The use of computers is an effective method to help students determine patterns and to break from established mind sets to obtain solutions in mathematical (and geometrical) situations.

- Introducing the different systems of geometry axioms-theorems helps to consider and evaluate unusual mathematical (and geometrical) ideas, to think through the possible consequences for mathematical situation.

- Verification of errors aids students to sense what is missing from a given mathematical situation and to ask questions that will enable one to fill in the missing mathematical information.

- The software Mathematica develops the ability to split general mathematical problems into specific subproblems.

My research aim is to map out in which proportions it is necessary and sufficient to apply DGS, since visualization on the computer is not the only teaching-device we have at our disposal to use during geometry lessons. Besides understanding the theorems, our students should find good proofs and it is necessary to practice the elementary geometrical constructions using compass and rulers. It is important to find an optimal qualitative and quantitative balance during lessons of time spent on visualizations and theoretical proofing of constructions. My task is to follow the development of these students for four years and to test their learning of Euler's line in the fourth-grade, because I think that concepts learned from different methods will give the expected results.

\section{Geometry I, Planimetry}

In Geometry I there is a problem, which we can use to follow the students' cognitive development in geometrical thinking using computer visualizations and elementary proofs. The given problem is Euler's line. The students' preliminary knowledge contained the important points of the triangles such as the center of the circumcircle, the orthocenter, the center of the inscribe circle and the centroid, which were studied during two lessons. First, the definition was given, and we constructed the Euler's line on the acute triangle. The next step was its proof, to show correctly the related theorem and the properties. The third step was the construction of these important points in special cases of the isosceles, the equilateral and the right-angle triangle. The homework was classical construction on paper in the case of the obtuse triangle. The students were asked to construct the triangle in adequate accuracy. I checked the homework and pointed out incorrect details and imperfect constructions.

The examination contained three parts (phases):

1. Visualization on the computer;

2. Comprehensive tasks for assessment;

3. Revision after the winter vacation. 
Until we got to the proof of the property of the Euler-line OTH, my students knew the basics of vector algebra such as their addition and multiplication with real numbers, and we proved the Hamilton-theorem:

$$
\overrightarrow{O B}+\overrightarrow{O C}+\overrightarrow{O A}=\overrightarrow{O H}
$$

as well as vector equality:

$$
\overrightarrow{C H}=2 \cdot \overrightarrow{O C_{1}}
$$

if $C_{1}$ is the midpoint of the segment $A B$ in the triangle $A B C$. In these phases the students' works are introduced, with their evaluation. In the first phase, visualization helped in the exploration of new concepts, their properties, and to find and understand new theorems.

In the second phase, students recalled to the accurate construction made on the computers by the dynamic geometry system. Their drawings were as accurate as possible. They made an effort to prepare as exact construction as possible using graphite pencils on paper.

The third phase took place one month later, after the assimilation period. There was an emphasis on the theoretical proof. It was enough to remind them of Euler's line, and they knew what their task was: from the given triangle, across the important points of the triangle, how one can get to the line OHT. But not all the solutions were satisfactory (to my disappointment). The most accurate solutions varied in their use of geometrical tools, one used isometric transformation, and another used perspective transformation in the proof, the third student recalled the proof applying vectors.

\section{Geometry II, Trigonometry}

In Geometry II Trigonometry is applied and used while proving important theorems of basic geometry. Theorems of Menelaus', Ceva's and Euler's line are proven. We verify these statements with the sine and cosine laws and then we apply them in our work the emphasis here is on experimenting. The aim is to develop the students' intuition skill using heuristic methods aided by visualization on the computer.

\section{Geometry III, Linear algebra and analytical geometry}

In Geometry III there is analytical geometry using coordinates of the point in Descartescoordinates, and equations of lines, circles, ellipses, hyperbolas and parabolas. Their visualization on the computer helps student understand the theory and make his/her own models on graph paper. The useful Dynamic Geometry System is GeoGebra. It is not unknown to the students of the third grade because they had met it in the second grade, but without the algebraic forms. Students are familiar with basic geometry constructions, important theorems of axiomatically built Euclidean and non-Euclidean geometry. However to prove important theorems in analytical form generally, there is a possibility to use software Mathematica 6.2 . This software helps calculate very long and complicated formulas and to simplify them more easier than human brain ever could. The computer helps in calculating, but the operator has to know what to calculate. Leadership is in the programmer's hand. The student has to know the algorithm of the process, the aim of the work, to lead the process to the end algorithmically. Using the computer made the work easier, however the main problem was solved in the student's mind. 
The test for assessment and evaluation was done and the results show that 40 percent of the class in 2008 of 20 students; and 56 percent of the class in 2009 of 18 students executed the task perfectly or very well.

\section{Apollonius' problems}

The Geometry I program was built on the introduction of basic geometrical knowledge. There are:

1. Isometric transformations: rotation, reflection, symmetry, translation;

2. Dilatation, symbol $H_{O, k}$, where $O$ is the center of the dilatation, $k$ is the ratio;

3. Inversion, symbol $\Psi_{i}(O, r)$, where $O$ is the center and $r$ is the radius of the inversion circle $i$.

As the example of using inversion on a circle there are Apollonius' problems, their constructions, discussion, analysis and proof. Those who have some experiences in construction using chalk on the blackboard with wooden compass and rulers have an idea of how to show and prove these interesting but difficult problems to their own students. The emphasis is on convincing instead of proving. A great help in visualization is some DGS. The most general and difficult case is obviously the case of three circles, which was covered in Book II of Apollonius' "On Tangencies". The basic problem is: Given three objects, each of which may be a point, line, or circle, draw a circle that is tangent to each. There are ten cases introduced.

\section{Is there geometry after Euclid?}

During the introduction and study of Hilbert's axioms, we become acquainted with the fact that there are 21 assumptions which underline the geometry published in Hilbert's classic text "Grundlagen der Geometrie" [11]: the incidence axioms, ordering axioms, congruence axioms, continuity axioms and the single parallel axiom equivalent to Euclid's fifth (parallel) postulate, as we can read in Euclid's "Elements" [9]. But it is our mission - the teacher's duty - to show the different possibilities of this axiom of parallels. At this point, the three basic axiom-systems are presented by Playfair's, Lobachevsky-Bolyai's and Riemann's axiom of parallel lines, but projective geometry is introduced by Desargues' and Pappus' theorems [7].

It is very important to develop the cognitive attitude of the students in Geometry I, to help their development of thinking skills, spatial perception and awareness, and the approach to the modern sciences. Fifteen year-old students have undeveloped mathematical thinking; they do not possess problem solving skills because they do not have experiences in solving such tasks. Geometry gives many opportunities for an effective development of such skills.

The spherical laws of the sine and cosine laws are applied on the Lénárt Sphere. Some students' work is shown. Summary the assessed/evaluated test ended with good results, students created beautiful constructions, very impressive works and interesting, amazing mistakes. Their fantasy produced wonderful ideas. 


\section{Summary}

This study examined several factors of the process of teaching and learning geometry using computers. The following research questions (with subcomponents) formulated the basis of the research:

1. How did computer-use help each student achieve good results and develop?

2. Which software was used for which exercise?

In the initial exercises in planar geometry it is useful to use the DGS "Euklides" because, as professor Szilassi Lajos put it,

"Euklides is a great software for its simplicity."

Later, the DGS GeoGebra is more useful with its geometry window at first and irs algebraic window used later. For long proofs, for accuracy software "Mathematica" is very practical.

Teaching geometry using visualizations on the computer prepares the scientist of the future to try every case of new problems that may arise to find and discover our environment and life. 


\section{9. Összefoglaló}

Geometriatanárként 2003 óta dolgozom a zentai Bolyai Tehetséggondozó Gimnáziumban. Módszerem a geometria tanításában a számígógépes vizualizáció, amit 2004 óta használok, mert a számítógép nagy pontossággal ábrázolja az alakzatokat, és a kezdeti, bemeneti elemek mozgatásával végigkísérhető az alakzat változása. Íly módon a szemlélő új kapcsolatokat fedezhet fel az elemek között és könnyebben belátja az adott probléma megoldását. Ma már létezik több és sokféle geometriai szerkesztőprogram. Az elsősök az Euklides DGS (dinamikus szerkesztőprogram) szoftvert használják, a többiek GeoGebra DGS-ben szerkesztenek, elemeznek, a harmadikosok pedig alkalmazzák bizonyításkor a Mathematica szoftvert. E módszer alkalmazásával növekszik a tanulók motivációja és teljesítménye, kedvelik a számítógépes tanteremben tartott órákat. Elvárásom ezen tanítási módszertől az, hogy a tanulók teljesítménye növekedni fog az érettségi vizsgán is.

Hat év alatt, mióta számítógépes vizualizációval színesítem a geometria órákat, az a tapasztalatom, hogy a tanulók a középiskolai tanulmányaik során megszerzett tapasztalatot, tudást és a módszerek alkalmazását felhasználják más szakterületeken is, hogy új ötleteket, megoldásokat találjanak a jelen és a jövő elméleti és technikai problémaira. Megtanulják alkalmazni a számítógépes vizualizációt saját, a geometriától, sőt a matematikától távoli területeken, különleges egyedi körülmények között, mert gondolkozásukat bővítve nyitottak a világ újszerü felfedezésére.

\section{Bevezetö}

A geometria tanítása a középiskolában igen nehéz feladat, ezt több pedagógiai és pszichológai didaktikai kutatás is igazolja, alátámasztja. Különösen az axiomatikusan felépített geometria tanítása és tanulása az érintett (illetve talán fejlesztésre váró) terület a kutatások szempontjából. A tanár szemszögéből izgalmas feladat segíteni a tanulóknak, hogy megértsék, megtanulják és alkalmazzák a geometriai tételeket. Szerbiában, Vajdaságban azt tapasztalom, hogy az óvodások kreatívak, ügyesek, az általános iskola alsósai nagyon okosak, talpraesettek, ám mire a felsősök megérkeznek a középiskolába, a kreativitásuk, ügyességük eltünik. Talán a problémamegoldó gondolkodás fejlesztésének hiánya, vagy az oktató-nevelö munka szükös anyagi és időbeli keretei miatt háttérbe szorított kreativitás csökkenése azt eredményezi, hogy a tanuló ifjúság szinte elfelejti megismerni az ókori görög geométerek csodálatos tudományát és világát. Az ábrázolások hiányosságai, a geometria tananyagának elméleti axiomatikus alapokra helyezése, és a tanterv szükös keretei háttérbe szorították a friss, fiatal elmék ,,rácsodálkozását” a geometriai alakzatokra.

A geometriai alakzatok sokszínüsége, a bennük rejlő szimmetriák, tökéletességük és változatosságuk sokak számára szinte láthatatlanul rejtve maradnak középiskolai tanulmányaik során.

A XXI. század gyermekeinek egyik legfontosabb ,társa” a számítógép, ezért játszik jelentős szerepet az oktatásban is. Marc Prensky digitális bennszülötteknek nevezei a ma gyermekeit, míg mi, többiek, (a tanárok, a szülők) a XX. századból csak digitális bevándorlók vagyunk módszeres kutatói gondolkodásmódunkkal. A kétféle gondolkodás- 
módot kell összehangolni a tanulási-tanítási folyamatban, szükséges fejleszteni a kommunikációt egymás megértésében.

Munkám során, a számítógéppel segített geometria tanítása közben Balka által megfogalmazott kritériumok a kreatív matematikai potenciál mérésére a következő módon kapnak értelmet:

- A számítógépes vizualizáció tanulása GeoGebra vagy Euklides DGS mellett segíti a tanulókat abban, hogy megfogalmazzák különböző matematikai (illetve geometriai) helyzetekben a matematikai feltételezéseket, hipotéziseket.

- A számítógép alkalmas eszköz, hogy a tanulók segítségére legyen felismerni a mintákat, szabályokat és alaptulajdonságokat a matematikai és nem-matmetaikai környezetben.

- A különbözö geometriai axióma-rendszerek megismerése és vizsgálata felcsillantja a tanuló elméjében az idegen vagy szokatlan (matematikai) ötletek elfogadásának lehetőségét bizonyos feltételek mellett.

- A hibás feladatok vagy hamis állítások gyors ellenőrizhetősége fejleszti a tanulók kritikai képességeit, hogy intelligens gondolataikkal helyes következtetési eljárassal ,jó" kérdéseket fogalmazzanak meg; valamint felismerjék a feladat esetleges hiányosságait.

- A dinamikus geometriai szoftverek, mint a GeoGebra vagy Euklides, valamint a nagyon gyors müveletek elvégzésére alkalmas Mathematica fejleszti a problémamegoldó gondolkodást, a feladat részekre bontását, felülvizsgálatát.

A fent említettek miatt tartom fontosnak, hogy alkalmazzuk a számítógépet a tanulási és tanítási folyamatban a teljesítmény növelése és a tanulók kognitív fejlődése érdekében. Szerencsére a geometriai szerkesztőprogramok megjelenése és exponenciális ütemü fejlődése nagyon gyors fejlődést eredményezett a geometria tanításában is.

Kutatásom célja, hogy feltérképezzem, milyen arányban szükséges és elégséges a dinamikus szerkesztőprogramok alkalmazása a tanításban, hiszen a számítógépes vizualizáció nem az egyetlen tanítási segédeszköz a geometriaórákon. A tételek megértése mellett a tanulóknak a ,jó" (helyes és elegáns) bizonyítást is fel kell ismerniük, de a pszichomotorikus képességek fejlesztése, a körzős-vonalzós klasszikus szerkesztés elsajátítása, begyakorlása is cél a tanítási-tanulási folyamatban. Fontosnak tartom a számbeli és minőségbeli arány felállítását, gyakorlását, a geometriai órák felosztását a számítógépes vizualizáció és az elméleti bizonyítások, szerkesztések között.

Feladatom, hogy végigkövessem a tanulók fejlődését a négy éves középiskola geometria tantárgyának három éves oktatásán keresztül, a nevezetes tételek segítségével. Úgy gondolom, hogy ha a tételeket, fogalmakat több oldalról megvilágítjuk, különböző aspektusait látjuk, átvizsgáljuk, akkor jobban megmaradnak az emlékeinkben, és a várt eredményt fogjuk kapni.

A munkában a geometria tanításának szintjeit tekintem át, amelyek a spiralitás elvével összhangban a következőek:

1. Planimetria, szintetikus bizonyítások, felfedező tanulás;

2. Trigonometria, trigonometrikus bizonyítások, mérések;

3. Lineáris algebra és analitikus geometria, analitikus bizonyítások. 


\section{Geometria I, Planimetria}

Egy elemi geometriai tétel, az Euler-egyenesre vonatkozó feladat vizsgálata,

$$
\overrightarrow{H T}=2 \cdot \overrightarrow{T O},
$$

ahol a $H$ pont jelöli a háromszög magasságpontját, $O$ a háromszög köré írt kör középpontját, $T$ a súlypontját. Ez a feladat mint alapprobléma jelenik meg az elsős tananyagban, ahol nyomon követhető a geometriai gondolkodás fejlődése, fejlesztése számítógépes vizualizációval és elemi bizonyításokkal. A tanulók előtudása: ismerték a háromszög nevezetes pontjait (beírt kör középpontja, körülírt kör középpontja, magasságpont, súlypont) a definíciókat, szerkesztéseket, bizonyításokat. Először az adott definíciók alapján egy hegyesszögű háromszögben szerkesztettünk, azután speciális egyenlő szárú, majd egyenlő oldalú és derékszögü háromszögeket szerkesztettünk. A következő lépésben bizonyítottunk, a kapcsolatokat keresték és fedezték fel a tanulók. A házi feladat a tompaszögü háromszög nevezetes pontjainak megszerkesztése volt, miután pontos utasításokat beszéltünk meg. A következő órán ellenőriztem a szerkesztési munkákat, rámutattam a hibás részletekre, és a nem teljesen pontos rajzokra.

A visszakérés-ellenőrzés (felmérés) három fázisa:

1. Vizualizáció számítógépen;

2. Összehasonlító felmérő feladatok osztályzásra;

3. Ismétlés a téli vakáció után.

Bizonyításaik közben tanulóim Hamilton tételét alkalmazták:

$$
\overrightarrow{O B}+\overrightarrow{O C}+\overrightarrow{O A}=\overrightarrow{O H}
$$

és az ,,ismert” vektoregyenletet (azért raktam idézőjelbe, mert sok tapasztalat és gyakorlat kell hozzá, hogy ismert legyen)

$$
\overrightarrow{C H}=2 \cdot \overrightarrow{O C_{1}},
$$

ahol $C_{1}$ pont az $A B$ szakasz felezőpontja az $A B C$ háromszögben. Ebben a fázisban bemutattam a tanulók munkáit, alkotásait, az értékeléssel együtt. A számítógépes vizualizáció az első fázisban segített az új fogalmak felfedezésében, ezek tulajdonságainak megértésében és a tételek bizonyításában.

\section{Geometria II, Trigonometria}

A geometria II tantárgyban a trigonometria alkalmazását dolgozzuk fel, miközben a geometria nevezetes tételeit (Menelaosz, Ceva, Euler-egyenes) bizonyítjuk.

Igazoljuk a szinusz- és koszinusz-tételt először elemi szintetikus módszerekkel, majd alkalmazzuk a nevezetes tételeknél. Itt a kísérleteken van a hangsúly, a tanulók intuíciójának, ösztönös megérzésének és a kreativitásának fejlesztésén, heurisztikus módszerekkel, amit számítógépes vizualizációval segítünk. 


\section{Geometria III, Lineáris algebra és analitikus geometria}

A geometria III tantárgyban analitikus geometria szerepel, ahol a pontokat Descartes-féle koordinátáikkal tüntetjük fel, az egyeneseket egyenleteikkel viszgáljuk és a másodrendü görbék egyeneleteit definiciójuk alapján vezetjük be. Ez utóbbiak ábrázolása számítógépen segít a tanulónak feltérképezni az alakzatokat, megérteni a tételeket, és saját, pontos ábrát rajzolni a négyzetrácsos füzetbe. A legalkalmasabb DGS a GeoGebra, ami már nem ismeretlen számukra, hisz alkalmazták az előző évben, csak az algebrai ablak vizsgálata nélkül. A tanulók ismerik az elemi geometriai szerkesztéseket, az euklideszi axiomatikusan felépített geometria nevezetes tételeit, valamint a nem-euklideszi geometriákat is. Mindemellett a nevezetes tételek bizonyításában általános alakban hasznos segítség a Mathematica szoftver, amely igen hosszú és komplikált képleteket könnyedén egyszerüsít, kiszámol, az emberi agynál gyorsabban.

\section{Apolloniosz problémái}

A geometria I tananyag felépítése az elemi geometriai tudáson túl tartalmazza az izometrikus transzformációkat, a hasonlósági leképezéseket és a körre vonatkozó inverziót. Példaként bemutatom Apolloniosz problémáit, a tíz lehetséges esetet. Mindegyik része a megfogalmazás, szerkesztés, elemzés, diszkúszió, bizonyítás. Akinek már volt tapasztalata fehér krétával fekete (zöld) táblára fa kőrzővel és vonalzóval megszerkeszteni a háromszög nevezetes pontjait és vonalait, érti a probléma nehézségét. Tudja, milyen súlyú feladat pontosan megszerkeszteni, bemutatni és bebizonyítani, ezeket az izgalmas, de nehéz tételeket a tanulóknak. A hangsúly most a szerkesztésen van és nem a bizonyításon. Több tucat egyedi papíron elkészített szerkesztés helyett (mellett) elég egy megfelelő segítség, valamely DGS-beli rajz. Ez utóbbi ábrát a számítógépen lehet módosítani alapelemeinek mozgatásával, amely hatalmas előny a kézi rajzokhoz képest.

Az általános és legnehezebb eset nyilván a három kört érintő kör, amelyet Apolloniosz "On Tangencies-Az érintőkről" II. könyvében találunk meg. Az alapprobléma:

Adott három objektumhoz, amelyek bármelyike pont, egyenes vagy kör, szerkeszd meg azt a kört, amely mindegyiket érinti.

Munkámban mind a tíz esetet bemutatom, amit a tanulókkal együtt feldolgoztunk. Közben megjellenek a tanulók felfedezései és szerepelnek saját szerkesztéseik is.

\section{Van-e más geometria az euklideszi geometrián kívül?}

Amíg az axiomatikusan felépített geometriát tanulmányoztuk, Hilbert 21 axiómájával ismerkedtünk meg. Hilbert a „Grundlagen der Geometri”" címü könyvében meghatározta és öt csoportba sorolta az axiómákat: az illeszkedési, a rendezési, az egybevágósági, a folytonossági, valamint a páratlan párhuzamossági axióma, amely Euklidész: „Elemek" ötödik posztulátumával egyenértékü, ekvivalens kijelentés. Mindeközben a tanár küldetése (manapság a feladata), hogy megmutassa a párhuzamossági axióma különböző változatait, amelyek a matematika történelme során fejlődtek ki. Ezen a ponton bemutatom a három axióma-rendszert, a Playfair-, a Bolyai-Lobacsevszkij- és a Riemann-féle párhuzamossági axiómákat, míg a projektív geometriát a Desarques- illetve Papposztétellel. Szükségesnek tartom a tanulók kognitív attitűdjének fejlesztését, hogy elősegítsük a gondolkodási készségek, a tér érzékelésének fejlődését, az intelligenciaszint emelkedését, a divergens gondolkodás megjelenését, valamint a modern tudományokhoz való hozzáférést. A 15 éves tanulóifjúság matematikai gondolkodása még nem teljesen fejlődött ki, 
mivel még nem szerezhettek tapasztalatot problémamegoldó gondolkodást igénylő feladatokban. Viszont a geometriai problémák alkalmat adnak effektiv fejlesztésekre.

A gömbi geometria szinusz- és koszinusz-tételeit alkalmazzuk, és kipróbáljuk a Lénárt Gömbön. Néhány tanulói munka is bemutatásra kerül. Összegzésként elmondhatom, hogy az értékelt feladatok jó eredményt adtak, gyönyörű rajzokkal, szép számításokkal és izgalmas, meglepő, meghökkentő hibákkal: a diákok csodálatos ötletekkel álltak elő.

Ez a dolgozat a geometria mint tudomány és tantárgy tanítási és tanulási folyamatait vizsgálja számítógép alkalmazása mellett. A kutatás fó kérdéseit a tananyag megértése, feldolgozása, továbbfejlesztése képezi, és a következő két alapkérdésre keresi és adja meg a választ:

1. Hogyan segítette elő a számítógép alkalmazása a tanulót a jó eredmény elérésében?

2. Melyik szoftvert milyen feladatokban használják a tanulók?

A kezdeti síkgeometriai feladatokban Euklidész DGS alkalmazása célszerü, mert ahogy Szilassi Lajos tanár úr megfogalmazta,

\section{,Egyszerüségében nagyszerü szoftver.”}

A későbbiekben a GeoGebra DGS használata segít, először csak a geometriai ablakkal, majd kinyitjuk az algebrai ablakot is. A hosszadalmas levezetések precíz, pontos felírására és bizonyítására a Mathematica alkalmas.

A geometria tanítása számítógépes vizualizációval a jövő tudósait felkészíti a különböző problémák megoldásainak megkeresésére, váratlan helyzetek és pillanatok gyors megoldására, hogy felfedezzék a még ismeretlent környező világunkban. 


\section{Appendix}

\section{Appendix 1}

The Serbian Ministry of Education is the author of the plans for the teaching of Geometry. The plans contain subjects of basic synthetic geometry, trigonometry and stereometry, analytical geometry.

The main topics in Geometry I are:

1. Introduction to geometry

2. Basic concepts and theoretical concepts

3. Group I: Axioms of Connection (Incidence)

4. Theorems from axioms of connection

5. Consequences of axioms of connection

6. Betweenness, a ternary relation linking points

7. Group II: Axioms of Order

8. Consequences of the axioms of order

9. Consequences of the axioms of connection and order

10. Group III: Axiom of Parallels (Euclids axiom)

11. Group III: Axiom of Parallels (Playfairs axiom)

12. Consequences of the axiom of parallels

13. The half plane, polygon, angle

14. Group IV: Axioms of congruence

15. Consequences of the axioms of congruence

16. The relation "less than" on the set of segments and angles

17. The addition of segments and angles

18. Group V: Axiom of Continuity (Archimedes axiom)

19. The measurement of angles and segments

20. The right angle and perpendicular lines

21. Isometric transformations 
22. The congruence of shapes

23. The sum of interior angles of a triangle

24. Alternate angles, interior angles of a transversal, corresponding angles

25. Triangle congruence theorems

26. Quadrilaterals, parallelograms

27. Properties of parallelograms

28. The important points of triangle

29. The important lines of triangle

30. The midline of triangle

31. The congruence of triangles

32. The congruence of quadrilaterals

33. The congruences on a circle

34. Vectors

35. The addition of vectors

36. Multiplying vectors

37. Operations with vectors

38. Constructions and graphical solutions

39. The linear combination of vectors

40. Linearly dependent vectors

41. Linearly independent vectors

42. Thales' theorem, proof with vectors

43. The central angle of the circle

44. The inscribed angle of the circle

45. The tangential quadrilateral

46. The inscribed quadrilateral

47. Normal lines and planes

48. The perpendicular dihedron

49. Skew lines

50. Constructions using a compass and rulers 
51. Direct and indirect isometry

52. Axial symmetry and constructions

53. A bundle (sheaf) of straight lines

54. Central symmetry and constructions

55. Translation and constructions

56. Isometries as production of axial symmetries

57. The ratio of segments

58. Dilatation

59. Similarity rules

60. Harmonic quadruple of points

61. Apollonius' circle

62. Ceva's theorem

63. Menelaus' theorem

64. Pythagoras' theorem

65. Stewart's theorem

66. Euclid's theorem

67. Similarity on the triangle

68. The power of a point

69. The application of similarity

70. Inversion

71. Constructions of Apollonius' problems

72. Trigonometric functions

73. The solution of right-angled triangles

74. The application of trigonometric identities

The main topics in Geometry II include:

1. The unit circle

2. Measuring angles on degrees and radian

3. The definition of trigonometric functions in the unit circle

4. Additional formulas 
5. Analysis of trigonometric functions

6. Graph of $y=\sin x$

7. Graph of $y=\cos x$

8. Graph of $y=\operatorname{tg} x$

9. Inverse trigonometric functions

10. Analysis and graph of inverse trigonometric functions

11. Trigonometric equations

12. Trigonometric inequalities

13. Sine law

14. Cosine law

15. The solution of the arbitrary triangle

16. The area of a triangle, formulas

17. The area of a polygon

18. The dihedron, the trihedron

19. The simple polyhedron

20. Euler's law on simple polyhedron and its proof

21. Regular polyhedrons

22. The prism

23. The pyramid

24. Cavalieri's principle

25. The surface and volume of prisms

26. The surface and volume of pyramids

27. The surface and volume of truncated pyramids

28. Cylindric surface

29. Conic surface

30. The surface and volume of solids of revolution

31. The surface and volume of sphere

32. Plane section of the sphere

33. Descriptive geometry in $2 \mathrm{D}$ and $3 \mathrm{D}$, constructions with compass and rulers 
The main topics in Geometry III are:

1. Binary operations and sets

2. Algebraic structures

3. The abstract groups

4. The abstract ring

5. Fields, examples

6. The vector field, vector space

7. Matrices

8. The addition of matrices

9. The multiplication of matrices

10. Operations with matrices

11. The adjunct matrix

12. The transpose matrix

13. The inverse matrix

14. The equation of matrices

15. Linear equations

16. The system of linear equations

17. Solution by Gauss' method

18. Solution by determinants

19. The vector with coordinates in $3 \mathrm{D}$

20. The linear combination of vectors, as homogenous linear system of equations

21. Operations with vectors given by coordinates in $3 \mathrm{D}$

22. The distance of two points

23. The scalar (dot) product of vectors

24. The vector (cross) product of vectors

25. Mixed product of vectors

26. Analytical geometry in $2 \mathrm{D}$

27. The equation of a line

28. The distance of a point from a line 
29. The angle of two lines

30. Parallel and perpendicular lines

31. Bisector

32. The curves of second order

33. The equation of a circle

34. The tangent of a circle

35. Two circles

36. Equation of an ellipse

37. The tangent line of an ellipse

38. The hyperbola and its asymptotes

39. The tangent line of a hyperbola

40. The equation of a parabola

41. The tangent line of parabola

42. The transformation of axes

43. Translation, as a matrix-operation

44. Rotation, as a matrix-operation 


\section{Appendix 2}

In this section are presented files from the attached CD.

- Euler's line in Euklides

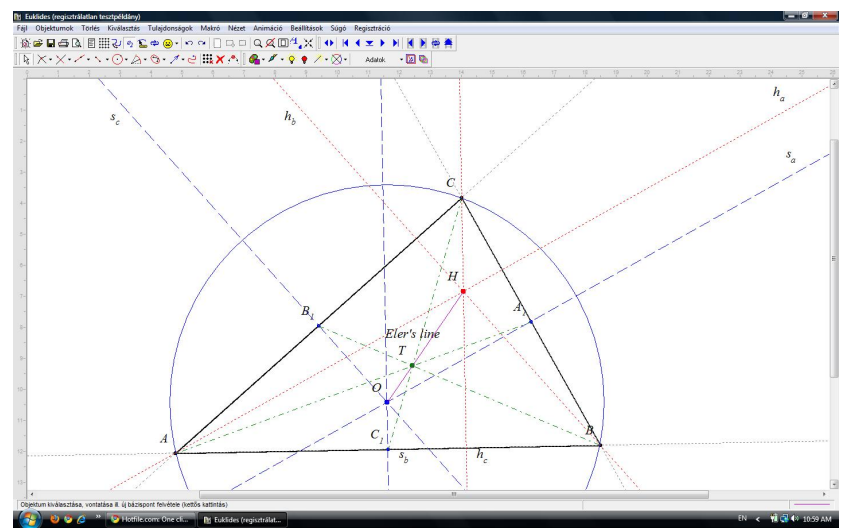

- Menelaus' theorem in GeoGebra

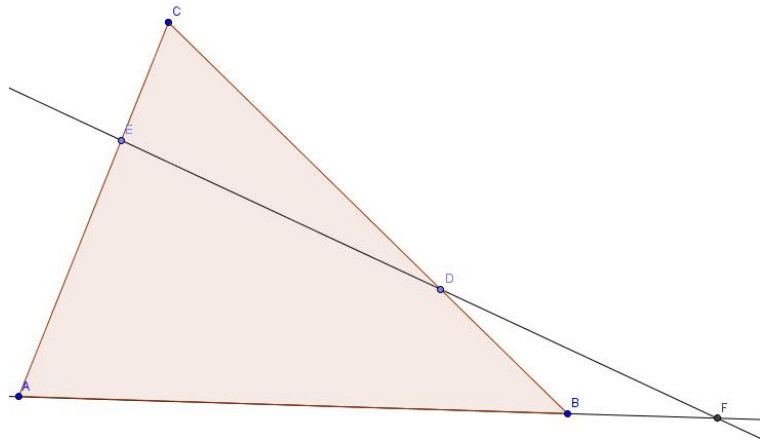

- Ceva's theorem in GeoGebra

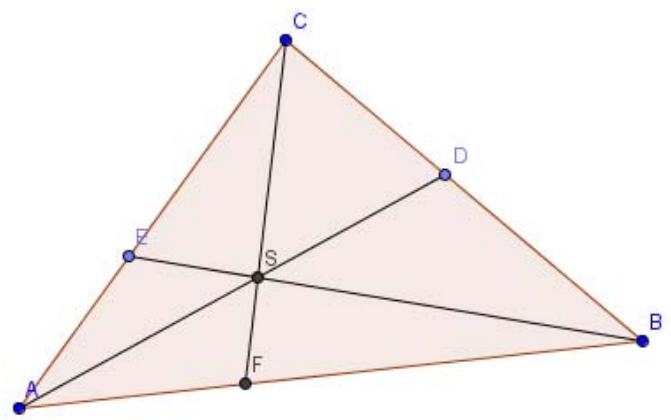


- Important points of the triangle in GeoGebra

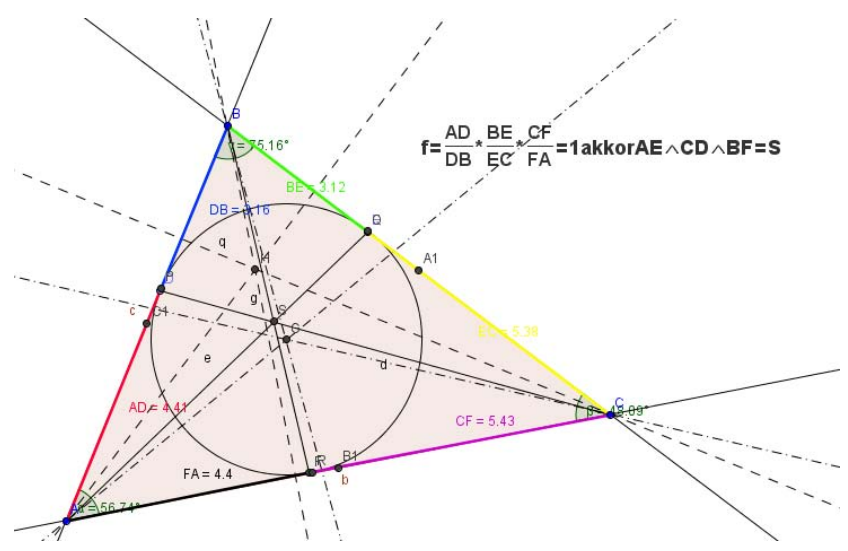

- Ptolemy's theorem in GeoGebra

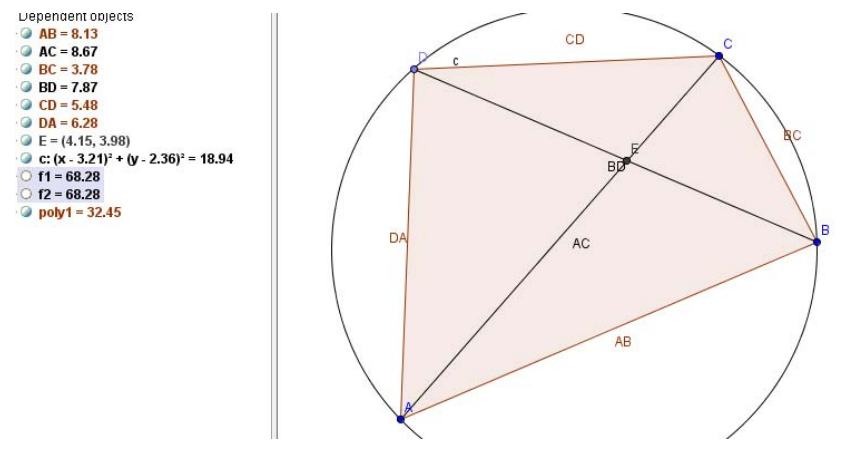

- Euler's line in GeoGebra

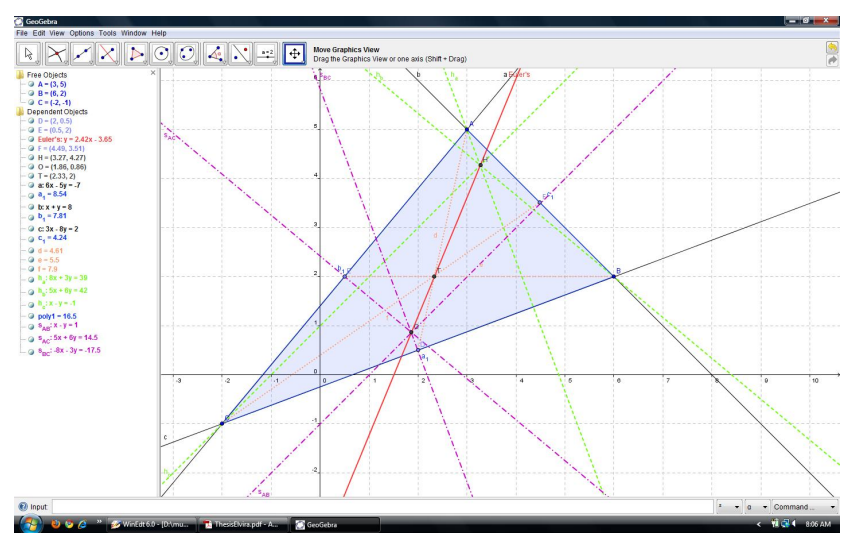




\section{Appendix 3}

\section{Mathematica-aided proof of the Ceva's theorem}

\section{THEOREM 1 (Ceva)}

Given a triangle $A B C$, and points $D, E$, and $F$ that lie on lines $B C, C A$ and $A B$ respectively, than lines $A D, B E$ and $C F$ are concurrent if and only if $\frac{A F}{F B} \frac{B D}{D C} \frac{C E}{E A}=1$.

\section{PROOF}

$\circ$ The hint of the proof

Two points, $\mathrm{F}$ and $\mathrm{D}$ are on the lines of the edges of the triangle, lines $\mathrm{CF}$ and $\mathrm{AD}$ have intersection point $\mathrm{S}$, then point $\mathrm{E}$ is the intersection point of line BS and edge AC.

Calculate the lenght of the segments AF, FB, BD, DC, CE and EA, then check the value of the formula above.

- The lines of the edges

Let the points $A=(\mathrm{a} 1, \mathrm{a} 2), B=(\mathrm{b} 1, \mathrm{~b} 2)$ and $\mathrm{C}(\mathrm{c} 1, \mathrm{c} 2)$ be the vertices of the triangle $\mathrm{ABC}$. The equations of the lines of the edges can be written as follows:

$$
\begin{aligned}
& A B=\operatorname{Det}\left[\left(\begin{array}{ccc}
a 1 & b 1 & x \\
a 2 & b 2 & y \\
1 & 1 & 1
\end{array}\right)\right] \\
& -a 2 b 1+a 1 b 2+a 2 x-b 2 x-a 1 y+b 1 y \\
& A C=\operatorname{Det}\left[\left(\begin{array}{ccc}
a 1 & c 1 & x \\
a 2 & c 2 & y \\
1 & 1 & 1
\end{array}\right)\right] \\
& -a 2 c 1+a 1 c 2+a 2 x-c 2 x-a 1 y+c 1 y \\
& C B=\operatorname{Det}\left[\left(\begin{array}{ccc}
c 1 & b 1 & x \\
c 2 & b 2 & y \\
1 & 1 & 1
\end{array}\right)\right] \\
& b 2 c 1-b 1 c 2-b 2 x+c 2 x+b 1 y-c 1 y
\end{aligned}
$$

- The points $F$ and $D$ on the lines of the edges

Let point $F=\{\mathrm{f} 1, \mathrm{f} 2\}$ be on the line AB:

$$
\begin{aligned}
& \mathbf{A B} / .\{\mathbf{x} \rightarrow \mathbf{f} 1, \mathbf{y} \rightarrow \mathbf{f} 2\} \\
& -a 2 b 1+a 1 b 2+a 2 f 1-b 2 f 1-a 1 f 2+b 1 f 2
\end{aligned}
$$

Assuming that the $\mathrm{AB}$ is not parallel to the $\mathrm{y}$-axis, $\mathrm{f} 2$ can be expressed by $\mathrm{f} 1$ : 


$$
\begin{aligned}
& \text { Solve }[A B=\mathbf{0} / .\{\mathbf{x} \rightarrow \mathbf{f} 1, \mathbf{y} \rightarrow \mathbf{f} 2\}, \mathbf{f 2}] \\
& \left\{\left\{\mathrm{f} 2 \rightarrow \frac{-\mathrm{a} 2 \mathrm{~b} 1+\mathrm{a} 1 \mathrm{~b} 2+\mathrm{a} 2 \mathrm{f} 1-\mathrm{b} 2 \mathrm{f} 1}{\mathrm{a} 1-\mathrm{b} 1}\right\}\right\}
\end{aligned}
$$

Let point $\mathrm{D}=\{\mathrm{d} 1, \mathrm{~d} 2\}$ be on the line $\mathrm{CB}$ :

$$
\begin{aligned}
& \mathrm{CB} / .\{\mathrm{x} \rightarrow \mathrm{d} 1, \mathbf{y} \rightarrow \mathrm{d} 2\} \\
& \mathrm{b} 2 \mathrm{c} 1-\mathrm{b} 1 \mathrm{c} 2-\mathrm{b} 2 \mathrm{~d} 1+\mathrm{c} 2 \mathrm{~d} 1+\mathrm{b} 1 \mathrm{~d} 2-\mathrm{c} 1 \mathrm{~d} 2
\end{aligned}
$$

Assuming that the CB is not parallel to the $\mathrm{y}-$ axis, $\mathrm{d} 2$ can be expressed by $\mathrm{d} 1$ :

$$
\begin{aligned}
& \text { Solve }[C B=0 / .\{x \rightarrow d 1, y \rightarrow d 2\}, d 2] \\
& \left\{\left\{d 2 \rightarrow \frac{-b 2 c 1+b 1 c 2+b 2 d 1-c 2 d 1}{b 1-c 1}\right\}\right\}
\end{aligned}
$$

- Connecting two vertices with the chosen points $F$ and $D$

The equations of the two lines $\mathrm{CF}$ and $\mathrm{AD}$ are :

$$
\begin{aligned}
& \mathrm{CF}=\operatorname{Det}\left[\left(\begin{array}{ccc}
\mathrm{c} 1 & \mathrm{f} 1 & \mathrm{x} \\
\mathrm{c} 2 & \frac{-\mathrm{a} 2 \mathrm{~b} 1+\mathrm{a} 1 \mathrm{~b} 2+\mathrm{a} 2 \mathrm{f} 1-\mathrm{b} 2 \mathrm{f1}}{\mathrm{a} 1-\mathrm{b} 1} & \mathrm{y} \\
1 & 1 & 1
\end{array}\right)\right] \\
& -c 2 f 1+\frac{c 1(-a 2 b 1+a 1 b 2+a 2 f 1-b 2 f 1)}{a 1-b 1}+c 2 x-\frac{(-a 2 b 1+a 1 b 2+a 2 f 1-b 2 f 1) x}{a 1-b 1}-c 1 y+f 1 y \\
& A D=\operatorname{Det}\left[\left(\begin{array}{ccc}
a 1 & d 1 & x \\
a 2 & \frac{-b 2 c 1+b 1 c 2+b 2 d 1-c 2 d 1}{b 1-c 1} & y \\
1 & 1 & 1
\end{array}\right)\right] \\
& -a 2 d 1+\frac{a 1(-b 2 c 1+b 1 c 2+b 2 d 1-c 2 d 1)}{b 1-c 1}+a 2 x-\frac{(-b 2 c 1+b 1 c 2+b 2 d 1-c 2 d 1) x}{b 1-c 1}-a 1 y+d 1 y
\end{aligned}
$$

Two lines $\mathrm{CF}$ and AD have intersection point $\mathrm{S}$ :

$$
\begin{aligned}
& \text { Solve }[\{C F=0, A D=0\} / .\{x \rightarrow s 1, y \rightarrow s 2\},\{s 1, s 2\}] \\
& \left\{\left\{\mathrm{s} 1 \rightarrow-\frac{-\mathrm{a} 1 \mathrm{~b} 1 \mathrm{c} 1+\mathrm{a} 1 \mathrm{c} 1 \mathrm{~d} 1+\mathrm{a} 1 \mathrm{c} 1 \mathrm{f} 1-\mathrm{a} 1 \mathrm{~d} 1 \mathrm{f} 1+\mathrm{b} 1 \mathrm{~d} 1 \mathrm{f} 1-\mathrm{c} 1 \mathrm{~d} 1 \mathrm{f} 1}{\mathrm{a} 1 \mathrm{~b} 1-\mathrm{a} 1 \mathrm{c} 1+\mathrm{b} 1 \mathrm{c} 1-\mathrm{b} 1 \mathrm{~d} 1-\mathrm{b} 1 \mathrm{f} 1+\mathrm{d} 1 \mathrm{f} 1},\right.\right. \\
& \mathrm{s} 2 \rightarrow-(-\mathrm{a} 2 \mathrm{~b} 1 \mathrm{c} 1+\mathrm{a} 1 \mathrm{~b} 2 \mathrm{c} 1-\mathrm{a} 1 \mathrm{~b} 1 \mathrm{c} 2+\mathrm{a} 2 \mathrm{~b} 1 \mathrm{~d} 1-\mathrm{a} 1 \mathrm{~b} 2 \mathrm{~d} 1+\mathrm{a} 1 \mathrm{c} 2 \mathrm{~d} 1+\mathrm{a} 2 \mathrm{c} 1 \mathrm{f} 1-\mathrm{b} 2 \mathrm{c} 1 \mathrm{f} 1+ \\
& \mathrm{b} 1 \mathrm{c} 2 \mathrm{f} 1-\mathrm{a} 2 \mathrm{~d} 1 \mathrm{f} 1+\mathrm{b} 2 \mathrm{~d} 1 \mathrm{f} 1-\mathrm{c} 2 \mathrm{~d} 1 \mathrm{f} 1) /(\mathrm{a} 1 \mathrm{~b} 1-\mathrm{a} 1 \mathrm{c} 1+\mathrm{b} 1 \mathrm{c} 1-\mathrm{b} 1 \mathrm{~d} 1-\mathrm{b} 1 \mathrm{f} 1+\mathrm{d} 1 \mathrm{f} 1)\}\}
\end{aligned}
$$


- The third line, BS has equation:

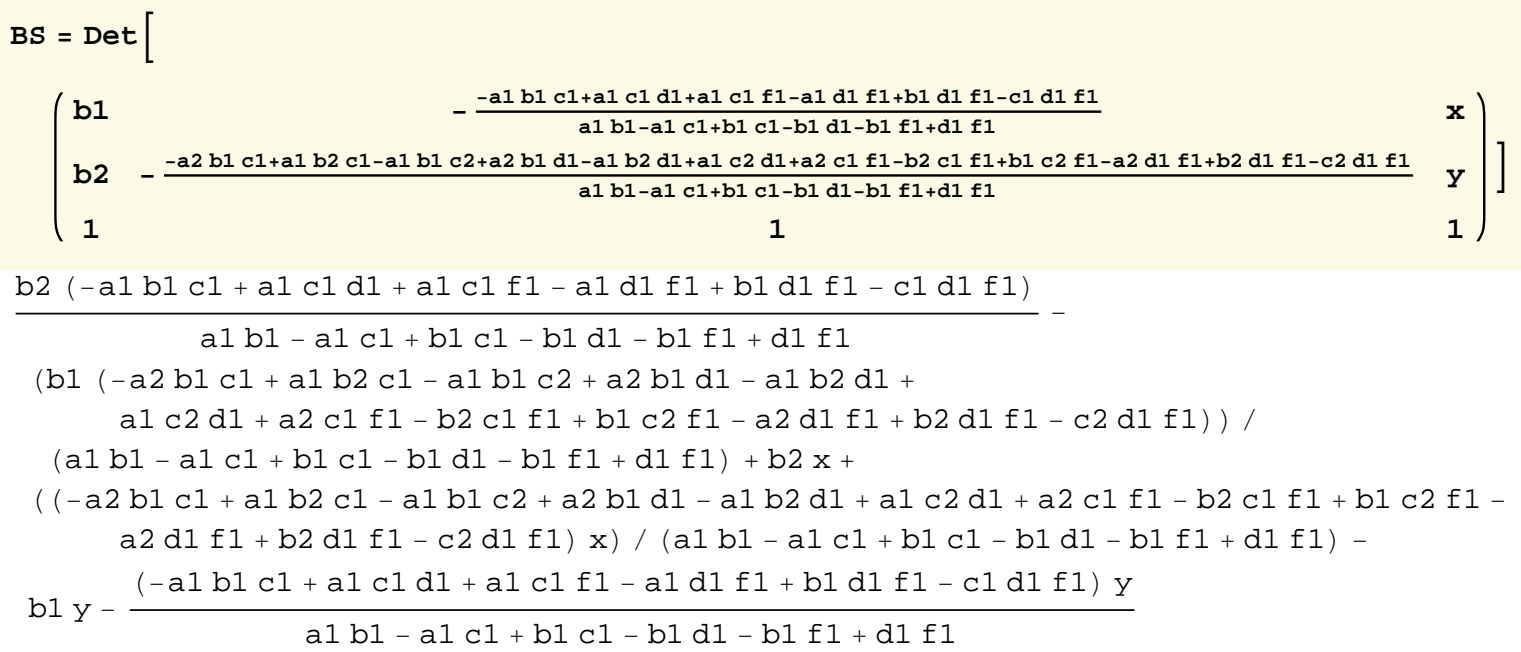

○ Third point, E

The third point, $\mathrm{E}=(\mathrm{e} 1, \mathrm{e} 2)$ is the intersection point of the line $\mathrm{BS}$ and edge $\mathrm{AC}$ :

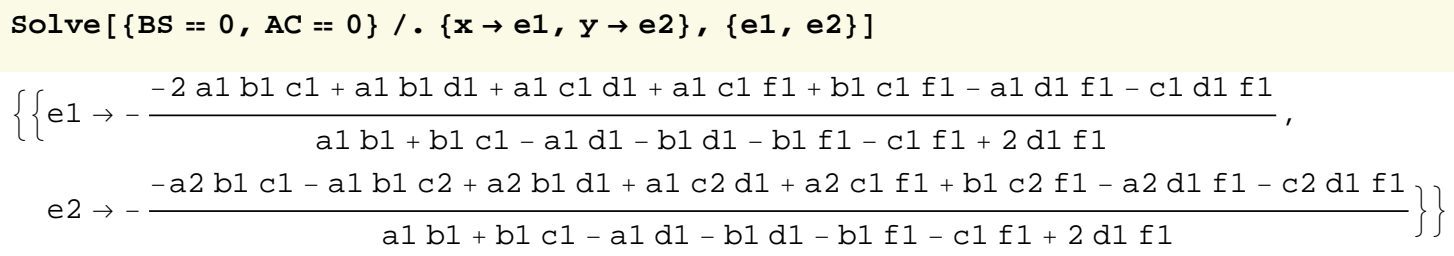

Then point $\mathrm{E}=\{\mathrm{e} 1, \mathrm{e} 2\}$ has coordinates as follows:

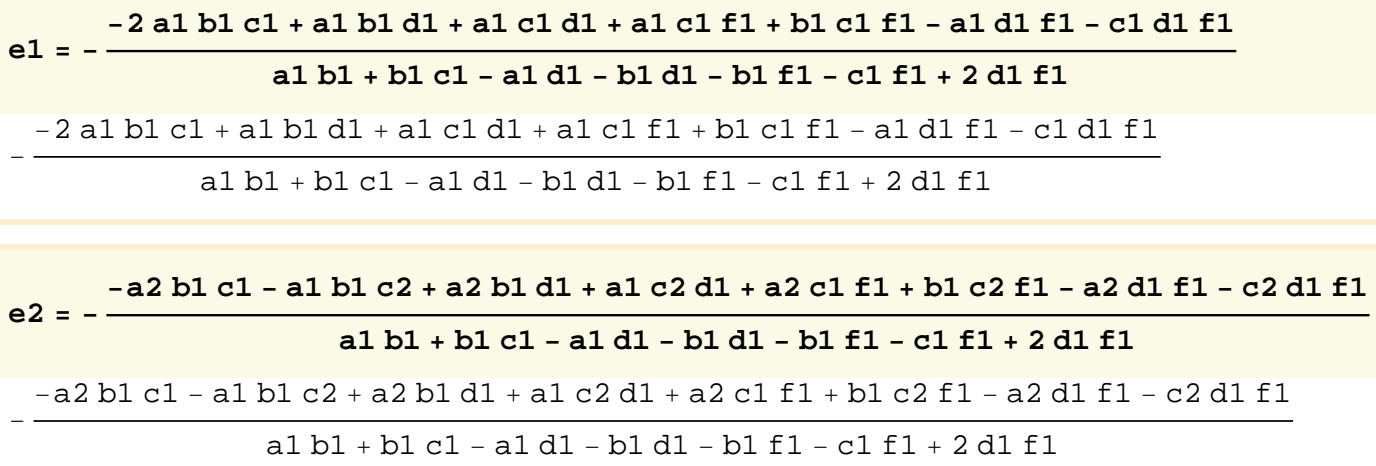

$\circ$ Lenght of the segments

The product of the proportions of the segments in Ceva's theoerem $\frac{A F}{F B} \frac{B D}{D C} \frac{C E}{E A}=1$ requires the lenght of the segments: 


$$
\begin{aligned}
& \text { hosszAF }=\sqrt{(a 1-f 1)^{2}+\left(a 2-\frac{-a 2 b 1+a 1 b 2+a 2 f 1-b 2 f 1}{a 1-b 1}\right)^{2}} \\
& \sqrt{(a 1-f 1)^{2}+\left(a 2-\frac{-a 2 b 1+a 1 b 2+a 2 f 1-b 2 f 1}{a 1-b 1}\right)^{2}}
\end{aligned}
$$

$$
\begin{aligned}
& \text { hosszFB }=\sqrt{(\mathbf{f} 1-\mathrm{b} 1)^{2}+\left(\frac{-a 2 b 1+a 1 b 2+a 2 f 1-b 2 f 1}{a 1-b 1}-b 2\right)^{2}} \\
& \sqrt{(-b 1+f 1)^{2}+\left(-b 2+\frac{-a 2 b 1+a 1 b 2+a 2 f 1-b 2 f 1}{a 1-b 1}\right)^{2}}
\end{aligned}
$$

$$
\begin{aligned}
& \text { hosszBD }=\sqrt{(b 1-d 1)^{2}+\left(b 2-\frac{-b 2 c 1+b 1 c 2+b 2 d 1-c 2 d 1}{b 1-c 1}\right)^{2}} \\
& \sqrt{(b 1-d 1)^{2}+\left(b 2-\frac{-b 2 c 1+b 1 c 2+b 2 d 1-c 2 d 1}{b 1-c 1}\right)^{2}}
\end{aligned}
$$

$$
\begin{aligned}
& \text { hosszDC }=\sqrt{(d 1-c 1)^{2}+\left(\frac{-b 2 c 1+b 1 c 2+b 2 d 1-c 2 d 1}{b 1-c 1}-c 2\right)^{2}} \\
& \sqrt{(-c 1+d 1)^{2}+\left(-c 2+\frac{-b 2 c 1+b 1 c 2+b 2 d 1-c 2 d 1}{b 1-c 1}\right)^{2}}
\end{aligned}
$$

$$
\begin{aligned}
& \text { hosszCE }=\sqrt{(\mathbf{c} 1-\mathbf{e} 1)^{2}+(\mathbf{c} 2-\mathbf{e} 2)^{2}} \\
& \sqrt{\left(\left(c 1+\frac{-2 a 1 b 1 c 1+a 1 b 1 d 1+a 1 c 1 d 1+a 1 c 1 f 1+b 1 c 1 f 1-a 1 d 1 f 1-c 1 d 1 f 1}{a 1 b 1+b 1 c 1-a 1 d 1-b 1 d 1-b 1 f 1-c 1 f 1+2 d 1 f 1}\right)^{2}+\right.} \\
& \left.\qquad\left(c 2+\frac{-a 2 b 1 c 1-a 1 b 1 c 2+a 2 b 1 d 1+a 1 c 2 d 1+a 2 c 1 f 1+b 1 c 2 f 1-a 2 d 1 f 1-c 2 d 1 f 1}{a 1 b 1+b 1 c 1-a 1 d 1-b 1 d 1-b 1 f 1-c 1 f 1+2 d 1 f 1}\right)^{2}\right)
\end{aligned}
$$

$$
\begin{aligned}
& \text { hosszEA }=\sqrt{(\mathbf{e} 1-\mathrm{a} 1)^{2}+(\mathbf{e} 2-\mathbf{a} 2)^{2}} \\
& \sqrt{\left(\left(-a 1-\frac{-2 \mathrm{a} 1 \mathrm{~b} 1 \mathrm{c} 1+\mathrm{a} 1 \mathrm{~b} 1 \mathrm{~d} 1+\mathrm{a} 1 \mathrm{c} 1 \mathrm{~d} 1+\mathrm{a} 1 \mathrm{c} 1 \mathrm{f} 1+\mathrm{b} 1 \mathrm{c} 1 \mathrm{f} 1-\mathrm{a} 1 \mathrm{~d} 1 \mathrm{f} 1-\mathrm{c} 1 \mathrm{~d} 1 \mathrm{f} 1}{\mathrm{a} 1 \mathrm{~b} 1+\mathrm{b} 1 \mathrm{c} 1-\mathrm{a} 1 \mathrm{~d} 1-\mathrm{b} 1 \mathrm{~d} 1-\mathrm{b} 1 \mathrm{f} 1-\mathrm{c} 1 \mathrm{f} 1+2 \mathrm{~d} 1 \mathrm{f} 1}\right)^{2}+\right.} \\
& \left(-\mathrm{a} 2-\frac{-\mathrm{a} 2 \mathrm{~b} 1 \mathrm{c} 1-\mathrm{a} 1 \mathrm{~b} 1 \mathrm{c} 2+\mathrm{a} 2 \mathrm{~b} 1 \mathrm{~d} 1+\mathrm{a} 1 \mathrm{c} 2 \mathrm{~d} 1+\mathrm{a} 2 \mathrm{c} 1 \mathrm{f} 1+\mathrm{b} 1 \mathrm{c} 2 \mathrm{f} 1-\mathrm{a} 2 \mathrm{~d} 1 \mathrm{f} 1-\mathrm{c} 2 \mathrm{~d} 1 \mathrm{f} 1}{\mathrm{a} 1 \mathrm{~b} 1+\mathrm{b} 1 \mathrm{c} 1-\mathrm{a} 1 \mathrm{~d} 1-\mathrm{b} 1 \mathrm{~d} 1-\mathrm{b} 1 \mathrm{f} 1-\mathrm{c} 1 \mathrm{f} 1+2 \mathrm{~d} 1 \mathrm{f} 1}\right)
\end{aligned}
$$

\section{- Ceva's formula}

Controlling the form of the Ceva's theorem, the product of the proportion of the segments: 


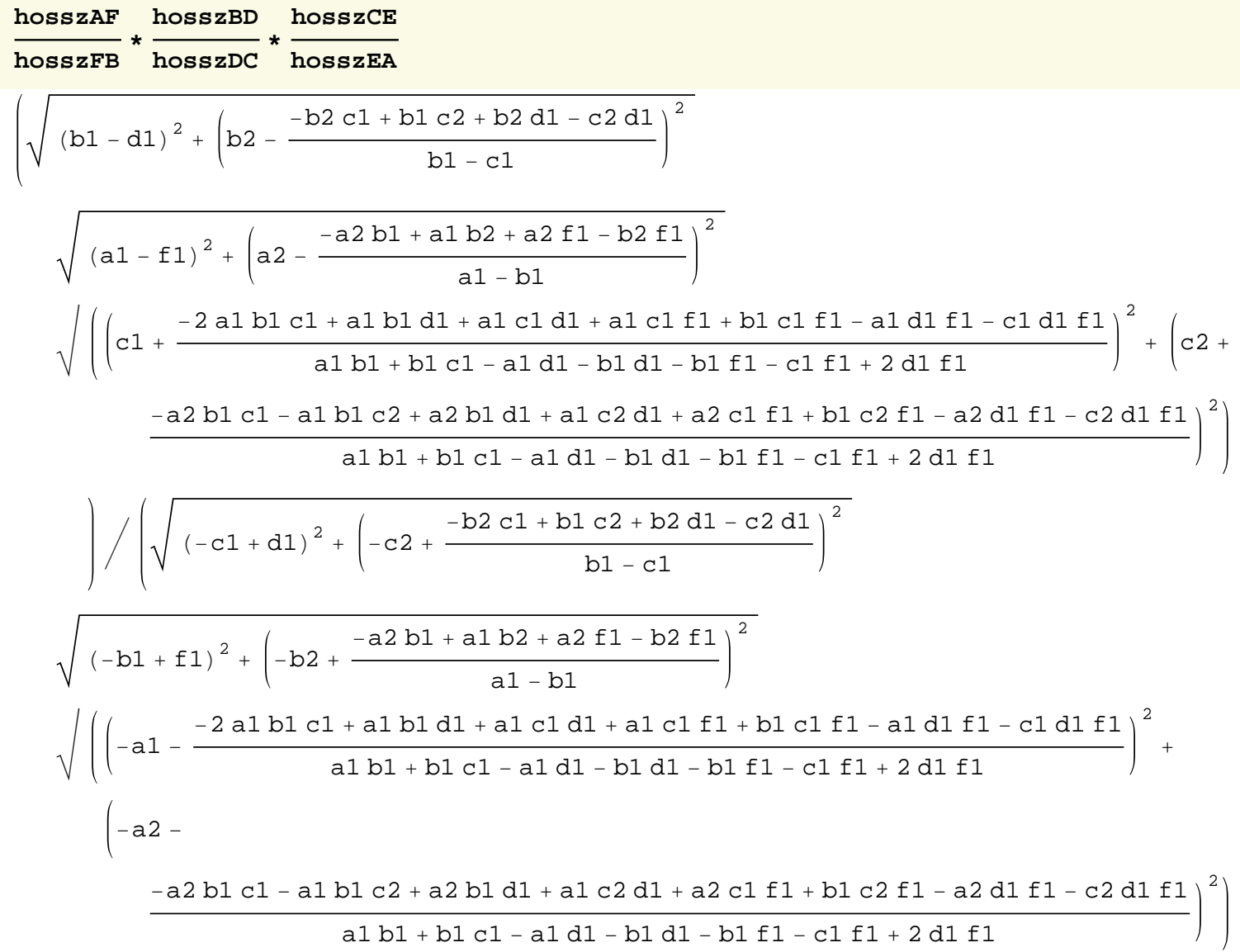

This formula is very compliceted to calculate, find its sqaure: 


$$
\begin{aligned}
& \left(\frac{\text { hosszAF }}{\text { hosszFB }} * \frac{\text { hosszBD }}{\text { hosszDC }} * \frac{\text { hosszCE }}{\text { hosszEA }}\right)^{2} \\
& \left(\left((\mathrm{~b} 1-\mathrm{d} 1)^{2}+\left(\mathrm{b} 2-\frac{-\mathrm{b} 2 \mathrm{c} 1+\mathrm{b} 1 \mathrm{c} 2+\mathrm{b} 2 \mathrm{~d} 1-\mathrm{c} 2 \mathrm{~d} 1}{\mathrm{~b} 1-\mathrm{c} 1}\right)^{2}\right)\right. \\
& \left((\mathrm{a} 1-\mathrm{f} 1)^{2}+\left(\mathrm{a} 2-\frac{-\mathrm{a} 2 \mathrm{~b} 1+\mathrm{a} 1 \mathrm{~b} 2+\mathrm{a} 2 \mathrm{f} 1-\mathrm{b} 2 \mathrm{f} 1}{\mathrm{a} 1-\mathrm{b} 1}\right)^{2}\right) \\
& \left(\left(\mathrm{c} 1+\frac{-2 \mathrm{a} 1 \mathrm{~b} 1 \mathrm{c} 1+\mathrm{a} 1 \mathrm{~b} 1 \mathrm{~d} 1+\mathrm{a} 1 \mathrm{c} 1 \mathrm{~d} 1+\mathrm{a} 1 \mathrm{c} 1 \mathrm{f} 1+\mathrm{b} 1 \mathrm{c} 1 \mathrm{f} 1-\mathrm{a} 1 \mathrm{~d} 1 \mathrm{f} 1-\mathrm{c} 1 \mathrm{~d} 1 \mathrm{f} 1}{\mathrm{a} 1 \mathrm{~b} 1+\mathrm{b} 1 \mathrm{c} 1-\mathrm{a} 1 \mathrm{~d} 1-\mathrm{b} 1 \mathrm{~d} 1-\mathrm{b} 1 \mathrm{f} 1-\mathrm{c} 1 \mathrm{f} 1+2 \mathrm{~d} 1 \mathrm{f} 1}\right)^{2}+(\mathrm{c} 2+\right. \\
& \left.\left.\left.\frac{-a 2 b 1 c 1-a 1 b 1 c 2+a 2 b 1 d 1+a 1 c 2 d 1+a 2 c 1 f 1+b 1 c 2 f 1-a 2 d 1 f 1-c 2 d 1 f 1}{a 1 b 1+b 1 c 1-a 1 d 1-b 1 d 1-b 1 f 1-c 1 f 1+2 d 1 f 1}\right)^{2}\right)\right) \\
& /\left(\left((-\mathrm{c} 1+\mathrm{d} 1)^{2}+\left(-\mathrm{c} 2+\frac{-\mathrm{b} 2 \mathrm{c} 1+\mathrm{b} 1 \mathrm{c} 2+\mathrm{b} 2 \mathrm{~d} 1-\mathrm{c} 2 \mathrm{~d} 1}{\mathrm{~b} 1-\mathrm{c} 1}\right)^{2}\right)\right. \\
& \left((-\mathrm{b} 1+\mathrm{f} 1)^{2}+\left(-\mathrm{b} 2+\frac{-\mathrm{a} 2 \mathrm{~b} 1+\mathrm{a} 1 \mathrm{~b} 2+\mathrm{a} 2 \mathrm{f} 1-\mathrm{b} 2 \mathrm{f} 1}{\mathrm{a} 1-\mathrm{b} 1}\right)^{2}\right) \\
& \left(\left(-a 1-\frac{-2 a 1 b 1 c 1+a 1 b 1 d 1+a 1 c 1 d 1+a 1 c 1 f 1+b 1 c 1 f 1-a 1 d 1 f 1-c 1 d 1 f 1}{a 1 b 1+b 1 c 1-a 1 d 1-b 1 d 1-b 1 f 1-c 1 f 1+2 d 1 f 1}\right)^{2}+(-a 2-\right. \\
& \left.\left.\left.\frac{-a 2 b 1 c 1-a 1 b 1 c 2+a 2 b 1 d 1+a 1 c 2 d 1+a 2 c 1 f 1+b 1 c 2 f 1-a 2 d 1 f 1-c 2 d 1 f 1}{a 1 b 1+b 1 c 1-a 1 d 1-b 1 d 1-b 1 f 1-c 1 f 1+2 d 1 f 1}\right)^{2}\right)\right)
\end{aligned}
$$

\section{Simplify [\%]}

1 


\section{Appendix 4 \\ Mathematica-aided proof of the Menelaus' theorem}

\section{THEOREM 1 Given points $A, B, C$ that form triangle $A B C$, and points $D, E, F$ that lie} on lines $B C, A C, A B$, points $D, E, F$ are collinear if and only if

$$
\frac{A F}{F B} \frac{B D}{D C} \frac{C E}{E A}=1
$$

\section{PROOF}

$\circ$ Hint of the proof

Two points, $\mathrm{F}$ and $\mathrm{D}$ are on the lines of the edges of the triangle, line FD intersects line of the side $\mathrm{AC}$ in point $\mathrm{E}$.

Calculate the lenght of the segments AF, FB, BD, DC, CE and EA, then check the value of the formula above.

$\circ$ Lines of the edges of the triangle

Let points $A=(a 1, a 2), B=(b 1, b 2)$ and $C=(c 1, c 2)$ be the vertices of the triangle $A B C$ then the equation of the sides of the triangle are :

$$
\begin{aligned}
& A B=\operatorname{Det}\left[\left(\begin{array}{ccc}
a 1 & b 1 & x \\
a 2 & b 2 & y \\
1 & 1 & 1
\end{array}\right)\right] \\
& -a 2 b 1+a 1 b 2+a 2 x-b 2 x-a 1 y+b 1 y \\
& A C=\operatorname{Det}\left[\left(\begin{array}{ccc}
a 1 & c 1 & x \\
a 2 & c 2 & y \\
1 & 1 & 1
\end{array}\right)\right] \\
& -a 2 c 1+a 1 c 2+a 2 x-c 2 x-a 1 y+c 1 y \\
& C B=\operatorname{Det}\left[\left(\begin{array}{ccc}
c 1 & b 1 & x \\
c 2 & b 2 & y \\
1 & 1 & 1
\end{array}\right)\right] \\
& b 2 c 1-b 1 c 2-b 2 x+c 2 x+b 1 y-c 1 y
\end{aligned}
$$

- The points $F$ and $D$ on the lines of the edges

Let point $F=\{\mathrm{f} 1, \mathrm{f} 2\}$ be on the line AB:

$$
\begin{aligned}
& \mathbf{A B} / .\{\mathbf{x} \rightarrow \mathbf{f} 1, \mathbf{y} \rightarrow \mathbf{f} 2\} \\
& -\mathrm{a} 2 \mathrm{~b} 1+\mathrm{a} 1 \mathrm{~b} 2+\mathrm{a} 2 \mathrm{f} 1-\mathrm{b} 2 \mathrm{f} 1-\mathrm{a} 1 \mathrm{f} 2+\mathrm{b} 1 \mathrm{f} 2
\end{aligned}
$$

Assuming that the $\mathrm{AB}$ is not parallel to the $\mathrm{y}$-axis, $\mathrm{f} 2$ can be expressed by $\mathrm{f} 1$ :

$$
\begin{aligned}
& \text { Solve }[A B==0 / .\{x \rightarrow f 1, y \rightarrow f 2\}, \mathbf{f 2}] \\
& \left\{\left\{f 2 \rightarrow \frac{-a 2 b 1+a 1 b 2+a 2 f 1-b 2 f 1}{a 1-b 1}\right\}\right\}
\end{aligned}
$$


2 Menelaus' theorem in Mathematica.nb

Let point $\mathrm{D}=\{\mathrm{d} 1, \mathrm{~d} 2\}$ be on the line $C B$ :

$$
\begin{aligned}
& \text { CB } / .\{x \rightarrow d 1, y \rightarrow d 2\} \\
& \text { b2 c1 - b1 c2 - b2 d1 + c2 d1 + b1 d2 - c1 d2 }
\end{aligned}
$$

Assuming that the CB is not parallel to the $\mathrm{y}$ - axis, $\mathrm{d} 2$ can be expressed by $\mathrm{d} 1$ :

$$
\begin{aligned}
& \text { Solve }[C B=\mathbf{0} / .\{\mathbf{x} \rightarrow \mathrm{d} 1, \mathbf{y} \rightarrow \mathbf{d} 2\}, \mathrm{d} 2] \\
& \left\{\left\{\mathrm{d} 2 \rightarrow \frac{-\mathrm{b} 2 \mathrm{c} 1+\mathrm{b} 1 \mathrm{c} 2+\mathrm{b} 2 \mathrm{~d} 1-\mathrm{c} 2 \mathrm{~d} 1}{\mathrm{~b} 1-\mathrm{c} 1}\right\}\right\}
\end{aligned}
$$

$\circ$ The equation of the line FD

$$
\begin{aligned}
& \text { FD }=\operatorname{Det}\left[\left(\begin{array}{ccc}
\frac{d 1}{-b 2 c 1+b 1 c 2+b 2 d 1-c 2 d 1} & \frac{-a 2 b 1+a 1 b 2+a 2 f 1-b 2 f 1}{a 1-b 1} & \mathbf{x} \\
\mathbf{1} 1 & \frac{1}{1} & 1
\end{array}\right)\right] \\
& -\frac{(-b 2 c 1+b 1 c 2+b 2 d 1-c 2 d 1) f 1}{b 1-c 1}+\frac{d 1(-a 2 b 1+a 1 b 2+a 2 f 1-b 2 f 1)}{a 1-b 1}+ \\
& \frac{(-b 2 c 1+b 1 c 2+b 2 d 1-c 2 d 1) x}{b 1-c 1}-\frac{(-a 2 b 1+a 1 b 2+a 2 f 1-b 2 f 1) x}{a 1-b 1}-d 1 y+f 1 y
\end{aligned}
$$

$\circ$ Third point $E$

If points $\mathrm{D}, \mathrm{E}$ and $\mathrm{F}$ are collinear, and $\mathrm{E}$ is on the line $\mathrm{AC}$ then $\mathrm{E}$ is the intersection point of the lines $\mathrm{AC}$ and $\mathrm{FD}$

$$
\begin{aligned}
& \text { Solve }[\{\mathbf{A C}=\mathbf{0}, \mathbf{F D}=\mathbf{0}\} / .\{\mathbf{x} \rightarrow \mathbf{e} 1, \mathbf{y} \rightarrow \mathbf{e} 2\},\{\mathbf{e} 1, \mathbf{e} 2\}] \\
& \left\{\left\{e 1 \rightarrow-\frac{a 1 b 1 d 1-a 1 c 1 d 1+a 1 c 1 f 1-b 1 c 1 f 1-a 1 d 1 f 1+c 1 d 1 f 1}{-a 1 b 1+b 1 c 1+a 1 d 1-b 1 d 1+b 1 f 1-c 1 f 1},\right.\right. \\
& \left.\left.\quad e 2 \rightarrow-\frac{a 2 b 1 c 1-a 1 b 1 c 2-a 2 b 1 d 1+a 1 c 2 d 1-a 2 c 1 f 1+b 1 c 2 f 1+a 2 d 1 f 1-c 2 d 1 f 1}{a 1 b 1-b 1 c 1-a 1 d 1+b 1 d 1-b 1 f 1+c 1 f 1}\right\}\right\}
\end{aligned}
$$

$\circ$ The length of the segments

The Menelaus' theorem, where the product of the proportion of the segments is in the formula $\frac{A F}{F B} \frac{B D}{D C} \frac{C E}{E A}=1$ requires the length of the segments

$$
\begin{aligned}
& \text { hosszAF }=\sqrt{(a 1-f 1)^{2}+\left(a 2-\frac{-a 2 b 1+a 1 b 2+a 2 f 1-b 2 f 1}{a 1-b 1}\right)^{2}} \\
& \sqrt{(a 1-f 1)^{2}+\left(a 2-\frac{-a 2 b 1+a 1 b 2+a 2 f 1-b 2 f 1}{a 1-b 1}\right)^{2}}
\end{aligned}
$$




$$
\begin{aligned}
& \text { hosszFB }=\sqrt{(f 1-b 1)^{2}+\left(\frac{-a 2 b 1+a 1 b 2+a 2 f 1-b 2 f 1}{a 1-b 1}-b 2\right)^{2}} \\
& \sqrt{(-b 1+f 1)^{2}+\left(-b 2+\frac{-a 2 b 1+a 1 b 2+a 2 f 1-b 2 f 1}{a 1-b 1}\right)^{2}} \\
& \begin{array}{l}
\operatorname{hosszBD}=\sqrt{(b 1-d 1)^{2}+\left(b 2-\frac{-b 2 c 1+b 1 c 2+b 2 d 1-c 2 d 1}{b 1-c 1}\right)^{2}} \\
\sqrt{(b 1-d 1)^{2}+\left(b 2-\frac{-b 2 c 1+b 1 c 2+b 2 d 1-c 2 d 1}{b 1-c 1}\right)^{2}}
\end{array} \\
& \text { hosszDC }=\sqrt{(d 1-c 1)^{2}+\left(\frac{-b 2 c 1+b 1 c 2+b 2 d 1-c 2 d 1}{b 1-c 1}-c 2\right)^{2}} \\
& \sqrt{(-c 1+d 1)^{2}+\left(-c 2+\frac{-b 2 c 1+b 1 c 2+b 2 d 1-c 2 d 1}{b 1-c 1}\right)^{2}}
\end{aligned}
$$

$$
\begin{aligned}
& \text { hosszCE }=\sqrt{\left(\left(c 1+\frac{a 1 b 1 d 1-a 1 c 1 d 1+a 1 c 1 f 1-b 1 c 1 f 1-a 1 d 1 f 1+c 1 d 1 f 1}{-a 1 b 1+b 1 c 1+a 1 d 1-b 1 d 1+b 1 f 1-c 1 f 1}\right)^{2}+\right.} \\
& \left.\left(c 2+\frac{a 2 b 1 c 1-a 1 b 1 c 2-a 2 b 1 d 1+a 1 c 2 d 1-a 2 c 1 f 1+b 1 c 2 f 1+a 2 d 1 f 1-c 2 d 1 f 1}{a 1 b 1-b 1 c 1-a 1 d 1+b 1 d 1-b 1 f 1+c 1 f 1}\right)^{2}\right) \\
& \sqrt{\left(\left(c 1+\frac{a 1 b 1 d 1-a 1 c 1 d 1+a 1 c 1 f 1-b 1 c 1 f 1-a 1 d 1 f 1+c 1 d 1 f 1}{-a 1 b 1+b 1 c 1+a 1 d 1-b 1 d 1+b 1 f 1-c 1 f 1}\right)^{2}+\right.} \\
& \left(c 2+\frac{a 2 b 1 c 1-a 1 b 1 c 2-a 2 b 1 d 1+a 1 c 2 d 1-a 2 c 1 f 1+b 1 c 2 f 1+a 2 d 1 f 1-c 2 d 1 f 1}{a 1 b 1-b 1 c 1-a 1 d 1+b 1 d 1-b 1 f 1+c 1 f 1}\right)^{2}
\end{aligned}
$$

$$
\begin{aligned}
& \text { hosszEA } \left.=\sqrt{\left(\left(-\frac{a 1 b 1 d 1-a 1 d 1 d 1+a 1 c 1 f 1-b 1 c 1 f 1-a 1 d 1 f 1+c 1 d 1 f 1}{-a 1 b 1+b 1 c 1+a 1 d 1-b 1 d 1+b 1 f 1-c 1 f 1}-a 1\right.\right.}\right)^{2}+ \\
& \left.\left(-\frac{a 2 b 1 c 1-a 1 b 1 c 2-a 2 b 1 d 1+a 1 c 2 d 1-a 2 c 1 f 1+b 1 c 2 f 1+a 2 d 1 f 1-c 2 d 1 f 1}{a 1 b 1-b 1 c 1-a 1 d 1+b 1 d 1-b 1 f 1+c 1 f 1}-a 2\right)^{2}\right) \\
& \left.\sqrt{\left(\left(-a 1-\frac{a 1 b 1 d 1-a 1 c 1 d 1+a 1 c 1 f 1-b 1 c 1 f 1-a 1 d 1 f 1+c 1 d 1 f 1}{-a 1 b 1+b 1 c 1+a 1 d 1-b 1 d 1+b 1 f 1-c 1 f 1}\right.\right.}\right)^{2}+ \\
& \left.\left(-a 2-\frac{a 2 b 1 c 1-a 1 b 1 c 2-a 2 b 1 d 1+a 1 c 2 d 1-a 2 c 1 f 1+b 1 c 2 f 1+a 2 d 1 f 1-c 2 d 1 f 1}{a 1 b 1-b 1 c 1-a 1 d 1+b 1 d 1-b 1 f 1+c 1 f 1}\right)^{2}\right)
\end{aligned}
$$

Calculate the form of the Menelaus' theorem, the product of the proportion of the segtments: 


$$
\begin{aligned}
& \text { hosszAF hosszBD } * \text { hosszCE } \\
& \overline{\text { hosszFB }} \text { hosszDC } * \overline{\text { hosszEA }} \\
& \left(\sqrt{(\mathrm{b} 1-\mathrm{d} 1)^{2}+\left(\mathrm{b} 2-\frac{-\mathrm{b} 2 \mathrm{c} 1+\mathrm{b} 1 \mathrm{c} 2+\mathrm{b} 2 \mathrm{~d} 1-\mathrm{c} 2 \mathrm{~d} 1}{\mathrm{~b} 1-\mathrm{c} 1}\right)^{2}}\right. \\
& \sqrt{(a 1-f 1)^{2}+\left(a 2-\frac{-a 2 b 1+a 1 b 2+a 2 f 1-b 2 f 1}{a 1-b 1}\right)^{2}} \\
& \left.\sqrt{\left(\left(c 1+\frac{a 1 b 1 d 1-a 1 c 1 d 1+a 1 c 1 f 1-b 1 c 1 f 1-a 1 d 1 f 1+c 1 d 1 f 1}{-a 1 b 1+b 1 c 1+a 1 d 1-b 1 d 1+b 1 f 1-c 1 f 1}\right.\right.}\right)^{2}+(c 2+ \\
& \left.\left.\left.\frac{a 2 b 1 c 1-a 1 b 1 c 2-a 2 b 1 d 1+a 1 c 2 d 1-a 2 c 1 f 1+b 1 c 2 f 1+a 2 d 1 f 1-c 2 d 1 f 1}{a 1 b 1-b 1 c 1-a 1 d 1+b 1 d 1-b 1 f 1+c 1 f 1}\right)^{2}\right)\right) \\
& /\left(\sqrt{(-c 1+d 1)^{2}+\left(-c 2+\frac{-b 2 c 1+b 1 c 2+b 2 d 1-c 2 d 1}{b 1-c 1}\right)^{2}}\right. \\
& \sqrt{(-\mathrm{b} 1+\mathrm{f} 1)^{2}+\left(-\mathrm{b} 2+\frac{-\mathrm{a} 2 \mathrm{~b} 1+\mathrm{a} 1 \mathrm{~b} 2+\mathrm{a} 2 \mathrm{f} 1-\mathrm{b} 2 \mathrm{f} 1}{\mathrm{a} 1-\mathrm{b} 1}\right)^{2}} \\
& \left.\sqrt{\left(\left(-a 1-\frac{a 1 b 1 d 1-a 1 c 1 d 1+a 1 c 1 f 1-b 1 c 1 f 1-a 1 d 1 f 1+c 1 d 1 f 1}{-a 1 b 1+b 1 c 1+a 1 d 1-b 1 d 1+b 1 f 1-c 1 f 1}\right.\right.}\right)^{2}+(-a 2- \\
& \left.\left.\left.\frac{a 2 b 1 c 1-a 1 b 1 c 2-a 2 b 1 d 1+a 1 c 2 d 1-a 2 c 1 f 1+b 1 c 2 f 1+a 2 d 1 f 1-c 2 d 1 f 1}{a 1 b 1-b 1 c 1-a 1 d 1+b 1 d 1-b 1 f 1+c 1 f 1}\right)^{2}\right)\right)
\end{aligned}
$$

This formula is very compliceted to calculate, find its sqaure: 


$$
\begin{aligned}
& \left(\frac{\text { hosszAF }}{\text { hosszFB }} * \frac{\text { hosszBD }}{\text { hosszDC }} * \frac{\text { hosszCE }}{\text { hosszEA }}\right) \wedge 2 \\
& \left(\left((\mathrm{~b} 1-\mathrm{d} 1)^{2}+\left(\mathrm{b} 2-\frac{-\mathrm{b} 2 \mathrm{c} 1+\mathrm{b} 1 \mathrm{c} 2+\mathrm{b} 2 \mathrm{~d} 1-\mathrm{c} 2 \mathrm{~d} 1}{\mathrm{~b} 1-\mathrm{c} 1}\right)^{2}\right)\right. \\
& \left((\mathrm{a} 1-\mathrm{f} 1)^{2}+\left(\mathrm{a} 2-\frac{-\mathrm{a} 2 \mathrm{~b} 1+\mathrm{a} 1 \mathrm{~b} 2+\mathrm{a} 2 \mathrm{f} 1-\mathrm{b} 2 \mathrm{f} 1}{\mathrm{a} 1-\mathrm{b} 1}\right)^{2}\right) \\
& \left(\left(\mathrm{c} 1+\frac{\mathrm{a} 1 \mathrm{~b} 1 \mathrm{~d} 1-\mathrm{a} 1 \mathrm{c} 1 \mathrm{~d} 1+\mathrm{a} 1 \mathrm{c} 1 \mathrm{f} 1-\mathrm{b} 1 \mathrm{c} 1 \mathrm{f} 1-\mathrm{a} 1 \mathrm{~d} 1 \mathrm{f} 1+\mathrm{c} 1 \mathrm{~d} 1 \mathrm{f} 1}{-\mathrm{a} 1 \mathrm{~b} 1+\mathrm{b} 1 \mathrm{c} 1+\mathrm{a} 1 \mathrm{~d} 1-\mathrm{b} 1 \mathrm{~d} 1+\mathrm{b} 1 \mathrm{f} 1-\mathrm{c} 1 \mathrm{f} 1}\right)^{2}+(\mathrm{c} 2+\right. \\
& \left.\left.\left.\frac{a 2 b 1 c 1-a 1 b 1 c 2-a 2 b 1 d 1+a 1 c 2 d 1-a 2 c 1 f 1+b 1 c 2 f 1+a 2 d 1 f 1-c 2 d 1 f 1}{a 1 b 1-b 1 c 1-a 1 d 1+b 1 d 1-b 1 f 1+c 1 f 1}\right)^{2}\right)\right) \\
& /\left((-\mathrm{c} 1+\mathrm{d} 1)^{2}+\left(-\mathrm{c} 2+\frac{-\mathrm{b} 2 \mathrm{c} 1+\mathrm{b} 1 \mathrm{c} 2+\mathrm{b} 2 \mathrm{~d} 1-\mathrm{c} 2 \mathrm{~d} 1}{\mathrm{~b} 1-\mathrm{c} 1}\right)^{2}\right) \\
& \left((-b 1+f 1)^{2}+\left(-b 2+\frac{-a 2 b 1+a 1 b 2+a 2 f 1-b 2 f 1}{a 1-b 1}\right)^{2}\right) \\
& \left(\left(-a 1-\frac{a 1 b 1 d 1-a 1 c 1 d 1+a 1 c 1 f 1-b 1 c 1 f 1-a 1 d 1 f 1+c 1 d 1 f 1}{-a 1 b 1+b 1 c 1+a 1 d 1-b 1 d 1+b 1 f 1-c 1 f 1}\right)^{2}+(-a 2-\right. \\
& \left.\left.\left.\frac{a 2 b 1 c 1-a 1 b 1 c 2-a 2 b 1 d 1+a 1 c 2 d 1-a 2 c 1 f 1+b 1 c 2 f 1+a 2 d 1 f 1-c 2 d 1 f 1}{a 1 b 1-b 1 c 1-a 1 d 1+b 1 d 1-b 1 f 1+c 1 f 1}\right)^{2}\right)\right)
\end{aligned}
$$

\section{Simplify [\%]}

1 


\section{Appendix 5 \\ Mathematica-aided proof of the Euler's line theorem}

THEOREM 1 For the given three points $A, B$ and $C$ the important points of the triangle $A B C$ orthocenter $(H)$, circumcenter $(\mathrm{O})$ and barycenter $(\mathrm{T})$ are collinear points, and $\overrightarrow{H T}=2 \overrightarrow{\mathrm{TO}}$.

PROOF

○ Hint of the proof

To solve this problem there are several subtasks to be worked out :

1. the equations of the lines $\mathrm{AB}, \mathrm{BC}$ and $\mathrm{AC}$;

2. the altitudes and the orthocenter of the triangle;

3. the medians and the barycenter;

4. the perpendicular bisectors and the circumcenter;

5. the equation of the line HO (or HT or OT) and the verification of whether the third point belongs to that line;

6. the coordinates of vectors $\overrightarrow{\mathrm{HT}}$ and $\overrightarrow{\mathrm{TO}}$;

7. checking the ratio of vectors $\overrightarrow{\mathrm{HT}}$ and $\overrightarrow{\mathrm{TO}}$.

- The equations of the lines $A B, B C$ and $A C$ of the triangle $A B C$

Let the points $A=\left(a_{1}, a_{2}\right), B=\left(b_{1}, b_{2}\right)$ and $C\left(c_{1}, c_{2}\right)$ be the vertices of the triangle $A B C$. The equations of the lines of the edges can be written as follows:

$$
\begin{aligned}
& A B=\operatorname{Det}\left[\left(\begin{array}{ccc}
a_{1} & b_{1} & x \\
a_{2} & b_{2} & y \\
1 & 1 & 1
\end{array}\right)\right]=0 \\
& -y a_{1}+x a_{2}+y b_{1}-a_{2} b_{1}-x b_{2}+a_{1} b_{2}=0
\end{aligned}
$$$$
A C=\operatorname{Det}\left[\left(\begin{array}{ccc}
a_{1} & c_{1} & x \\
a_{2} & c_{2} & y \\
1 & 1 & 1
\end{array}\right)\right]=0
$$

$-y a_{1}+x a_{2}+y c_{1}-a_{2} c_{1}-x c_{2}+a_{1} c_{2}=0$ 


$$
C B=\operatorname{Det}\left[\left(\begin{array}{ccc}
c_{1} & b_{1} & x \\
c_{2} & b_{2} & y \\
1 & 1 & 1
\end{array}\right)\right]=0
$$

$y b_{1}-x b_{2}-y_{1}+b_{2} c_{1}+x c_{2}-b_{1} c_{2}=0$

- The altitudes and the orthocenter of the triangle

Find the equation of the perpendicular lines to the edges of the triangle ABC

The altitudes of the triangle are the following lines: $h_{a}$ across vertex $A$ is perpendicular to line BC

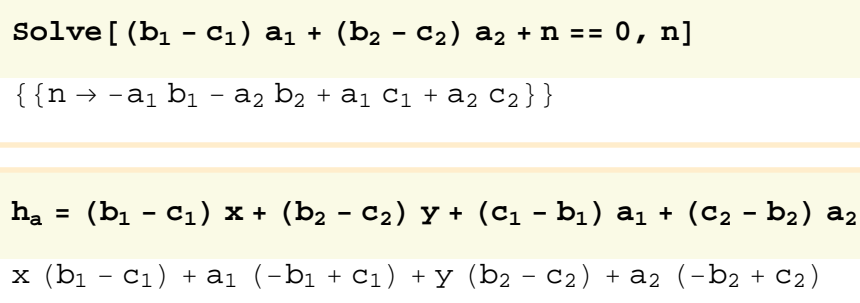

$h_{b}$ across vertex $B$ is perpendicular to line AC

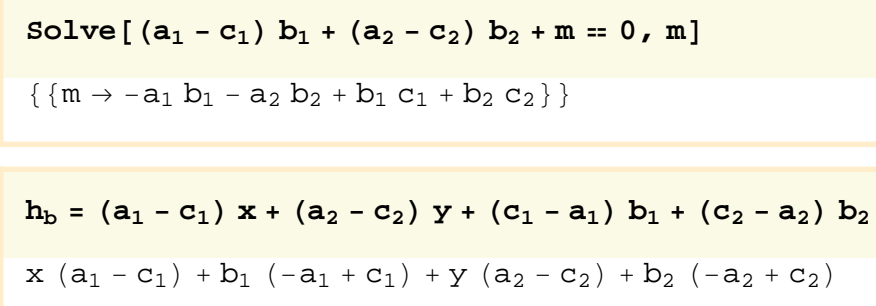

The intersection point of two altitudes is the orthocenter $\mathrm{H}=\left(h_{1}, h_{2}\right)$ of the triangle.

Solve $\left[\left\{h_{a}=0, h_{b}=0\right\} / .\left\{x \rightarrow h_{1}, y \rightarrow h_{2}\right\},\left\{h_{1}, h_{2}\right\}\right]$

$\left\{\left\{h_{1} \rightarrow-\left(-a_{1} a_{2} b_{1}-a_{2}^{2} b_{2}+a_{1} b_{1} b_{2}+a_{2} b_{2}^{2}+a_{1} a_{2} c_{1}-b_{1} b_{2} c_{1}+a_{2}^{2} c_{2}-b_{2}^{2} c_{2}-a_{1} c_{1} c_{2}+b_{1} c_{1} c_{2}-a_{2} c_{2}^{2}+b_{2} c_{2}^{2}\right) /\right.\right.$ $\left(a_{2} b_{1}-a_{1} b_{2}-a_{2} c_{1}+b_{2} c_{1}+a_{1} c_{2}-b_{1} c_{2}\right)$,

$h_{2} \rightarrow-\left(a_{1}^{2} b_{1}-a_{1} b_{1}^{2}+a_{1} a_{2} b_{2}-a_{2} b_{1} b_{2}-a_{1}^{2} c_{1}+b_{1}^{2} c_{1}+a_{1} c_{1}^{2}-b_{1} c_{1}^{2}-a_{1} a_{2} c_{2}+b_{1} b_{2} c_{2}+a_{2} c_{1} c_{2}-b_{2} c_{1} c_{2}\right) /$

$\left.\left.\left(a_{2} b_{1}-a_{1} b_{2}-a_{2} c_{1}+b_{2} c_{1}+a_{1} c_{2}-b_{1} c_{2}\right)\right\}\right\}$ 


\section{The medians and the barycenter}

Medians of the triangle are line across a vertex and the midpoint of the opposite side. If the midpoints of the edges are A', B' and C' on the sides BC, AC and $\mathrm{AB}$, then the medians are as follows :

$$
\begin{aligned}
& \mathbf{A A}^{\prime}=\operatorname{Det}\left[\left(\begin{array}{ccc}
a_{1} & \frac{b_{1}+c_{1}}{2} & \mathbf{x} \\
a_{2} & \frac{b_{2}+c_{2}}{2} & \mathbf{y} \\
1 & 1 & 1
\end{array}\right)\right] \\
& -y a_{1}+x a_{2}+\frac{y b_{1}}{2}-\frac{a_{2} b_{1}}{2}-\frac{x b_{2}}{2}+\frac{a_{1} b_{2}}{2}+\frac{y c_{1}}{2}-\frac{a_{2} c_{1}}{2}-\frac{x c_{2}}{2}+\frac{a_{1} c_{2}}{2}
\end{aligned}
$$

$$
\begin{aligned}
& B^{\prime}=\operatorname{Det}\left[\left(\begin{array}{ccc}
b_{1} & \frac{a_{1}+c_{1}}{2} & x \\
b_{2} & \frac{a_{2}+c_{2}}{2} & y \\
1 & 1 & 1
\end{array}\right)\right] \\
& \frac{y a_{1}}{2}-\frac{x a_{2}}{2}-y b_{1}+\frac{a_{2} b_{1}}{2}+x b_{2}-\frac{a_{1} b_{2}}{2}+\frac{y c_{1}}{2}-\frac{b_{2} c_{1}}{2}-\frac{x c_{2}}{2}+\frac{b_{1} c_{2}}{2}
\end{aligned}
$$

$$
\begin{aligned}
& C^{\prime}=\operatorname{Det}\left[\left(\begin{array}{ccc}
c_{1} & \frac{b_{1}+a_{1}}{2} & \mathbf{x} \\
c_{2} & \frac{b_{2}+a_{2}}{2} & y \\
1 & 1 & 1
\end{array}\right)\right] \\
& \frac{y a_{1}}{2}-\frac{x a_{2}}{2}+\frac{y b_{1}}{2}-\frac{x b_{2}}{2}-y c_{1}+\frac{a_{2} c_{1}}{2}+\frac{b_{2} c_{1}}{2}+x c_{2}-\frac{a_{1} c_{2}}{2}-\frac{b_{1} c_{2}}{2}
\end{aligned}
$$

Barycenter of the triangle is $T=\left(t_{1}, t_{2}\right)$, what is intersection point of the medians $\mathrm{AA}^{\prime}$, $\mathrm{BB}^{\prime}$ and $\mathrm{CC} \mathrm{\prime}^{\prime}$

$$
\begin{aligned}
& t_{1}=\left(a_{1}+b_{1}+c_{1}\right) / 3 \\
& \frac{1}{3}\left(a_{1}+b_{1}+c_{1}\right)
\end{aligned}
$$

$$
\begin{aligned}
& t_{\mathbf{2}}=\left(\mathbf{a}_{\mathbf{2}}+\mathbf{b}_{\mathbf{2}}+\mathbf{c}_{\mathbf{2}}\right) / \mathbf{3} \\
& \frac{1}{3}\left(\mathrm{a}_{2}+\mathrm{b}_{2}+\mathrm{c}_{2}\right)
\end{aligned}
$$


The intersection point of medians AA' and BB' must be T, the barycenter (centroid) of the triangle.

$$
\begin{aligned}
& \text { Solve }\left[\left\{\mathbf{A A}^{\prime}=0, \mathbf{B B}^{\prime}=0\right\},\{\mathbf{x}, \mathbf{y}\}\right] \\
& \left\{\left\{x \rightarrow \frac{1}{3}\left(a_{1}+b_{1}+c_{1}\right), y \rightarrow \frac{1}{3}\left(a_{2}+b_{2}+c_{2}\right)\right\}\right\}
\end{aligned}
$$

- The perpendicular bisectors and the circumcenter

Find the prallel lines to the altitudes across the midpoints of the edges.

$$
\begin{aligned}
& \text { Solve }\left[\left(\mathbf{a}_{1}-\mathbf{b}_{1}\right) \frac{\mathbf{a}_{1}+\mathbf{b}_{1}}{\mathbf{2}}+\left(\mathbf{a}_{\mathbf{2}}-\mathbf{b}_{2}\right) \frac{\mathbf{a}_{2}+\mathbf{b}_{\mathbf{2}}}{\mathbf{2}}+\mathbf{n}=\mathbf{=}, \mathbf{n}\right] \\
& \left\{\left\{n \rightarrow \frac{1}{2}\left(-a_{1}^{2}-a_{2}^{2}+b_{1}^{2}+b_{2}^{2}\right)\right\}\right\}
\end{aligned}
$$

$$
\begin{aligned}
& \text { Solve }\left[\left(\mathbf{a}_{1}-\mathbf{c}_{1}\right) \frac{\mathbf{a}_{1}+\mathbf{c}_{1}}{\mathbf{2}}+\left(\mathbf{a}_{2}-\mathbf{c}_{2}\right) \frac{\mathbf{a}_{2}+\mathbf{c}_{2}}{2}+\mathbf{m}=\mathbf{2} \mathbf{0}, \mathbf{m}\right] \\
& \left\{\left\{m \rightarrow \frac{1}{2}\left(-a_{1}^{2}-a_{2}^{2}+c_{1}^{2}+c_{2}^{2}\right)\right\}\right\}
\end{aligned}
$$

The perpendicular bisectors of the sides of the triangle $\mathrm{ABC}$ are $: s_{\mathrm{ab}}$ line across the midpoint $\mathrm{C}^{\prime}$ of the segment $\mathrm{AB}$ is parallel to $h_{c}$

$$
\begin{aligned}
& \mathbf{s}_{\mathbf{a b}}=\mathbf{x}\left(\mathbf{a}_{1}-\mathbf{b}_{1}\right)+\mathbf{y}\left(\mathbf{a}_{\mathbf{2}}-\mathbf{b}_{\mathbf{2}}\right)+\frac{\mathbf{1}}{\mathbf{2}}\left(-\mathbf{a}_{1}^{2}-\mathbf{a}_{\mathbf{2}}^{2}+\mathbf{b}_{1}^{2}+\mathbf{b}_{2}^{2}\right) \\
& x\left(a_{1}-b_{1}\right)+y\left(a_{2}-b_{2}\right)+\frac{1}{2}\left(-a_{1}^{2}-a_{2}^{2}+b_{1}^{2}+b_{2}^{2}\right)
\end{aligned}
$$

$S_{a c}$ line across the midpoint $B^{\prime}$ of the segment AC is parallel to $h_{b}$

$$
\begin{aligned}
& \mathbf{s}_{\mathbf{a c}}=\mathbf{x}\left(\mathbf{a}_{\mathbf{1}}-\mathbf{c}_{\mathbf{1}}\right)+\mathbf{y}\left(\mathbf{a}_{\mathbf{2}}-\mathbf{c}_{\mathbf{2}}\right)+\frac{\mathbf{1}}{\mathbf{2}}\left(-\mathbf{a}_{\mathbf{1}}^{2}-\mathbf{a}_{\mathbf{2}}^{2}+\mathbf{c}_{\mathbf{1}}^{2}+\mathbf{c}_{\mathbf{2}}^{2}\right) \\
& x\left(a_{1}-c_{1}\right)+y\left(a_{2}-c_{2}\right)+\frac{1}{2}\left(-a_{1}^{2}-a_{2}^{2}+c_{1}^{2}+c_{2}^{2}\right)
\end{aligned}
$$

The intersection point of the perpendicular bisectors is the circumcenter $\mathrm{O}=\left(o_{1}, o_{2}\right)$ 
Solve $\left[\left\{s_{a b}=0, s_{a c}=0\right\} / .\left\{x \rightarrow o_{1}, y \rightarrow o_{2}\right\},\left\{o_{1}, o_{2}\right\}\right]$

$$
\begin{gathered}
\left\{\left\{o_{1} \rightarrow \frac{a_{2} b_{1}^{2}-a_{1}^{2} b_{2}-a_{2}^{2} b_{2}+a_{2} b_{2}^{2}-a_{2} c_{1}^{2}+b_{2} c_{1}^{2}+a_{1}^{2} c_{2}+a_{2}^{2} c_{2}-b_{1}^{2} c_{2}-b_{2}^{2} c_{2}-a_{2} c_{2}^{2}+b_{2} c_{2}^{2}}{2\left(a_{2} b_{1}-a_{1} b_{2}-a_{2} c_{1}+b_{2} c_{1}+a_{1} c_{2}-b_{1} c_{2}\right)}\right.\right. \\
\left.\left.o_{2} \rightarrow-\frac{-a_{1}^{2} b_{1}-a_{2}^{2} b_{1}+a_{1} b_{1}^{2}+a_{1} b_{2}^{2}+a_{1}^{2} c_{1}+a_{2}^{2} c_{1}-b_{1}^{2} c_{1}-b_{2}^{2} c_{1}-a_{1} c_{1}^{2}+b_{1} c_{1}^{2}-a_{1} c_{2}^{2}+b_{1} c_{2}^{2}}{2\left(a_{2} b_{1}-a_{1} b_{2}-a_{2} c_{1}+b_{2} c_{1}+a_{1} c_{2}-b_{1} c_{2}\right)}\right\}\right\}
\end{gathered}
$$

- The equation of the line HO (or HT or OT) and the verification of whether the third point belongs to that line

Equation of the line $\mathrm{HO}$ is below, that is Euler's line $\left(\begin{array}{ccc}\mathrm{O}_{1} & \mathrm{~h}_{1} & \mathrm{x} \\ \mathrm{O}_{2} & \mathrm{~h}_{2} & \mathrm{y} \\ 1 & 1 & 1\end{array}\right)=0$

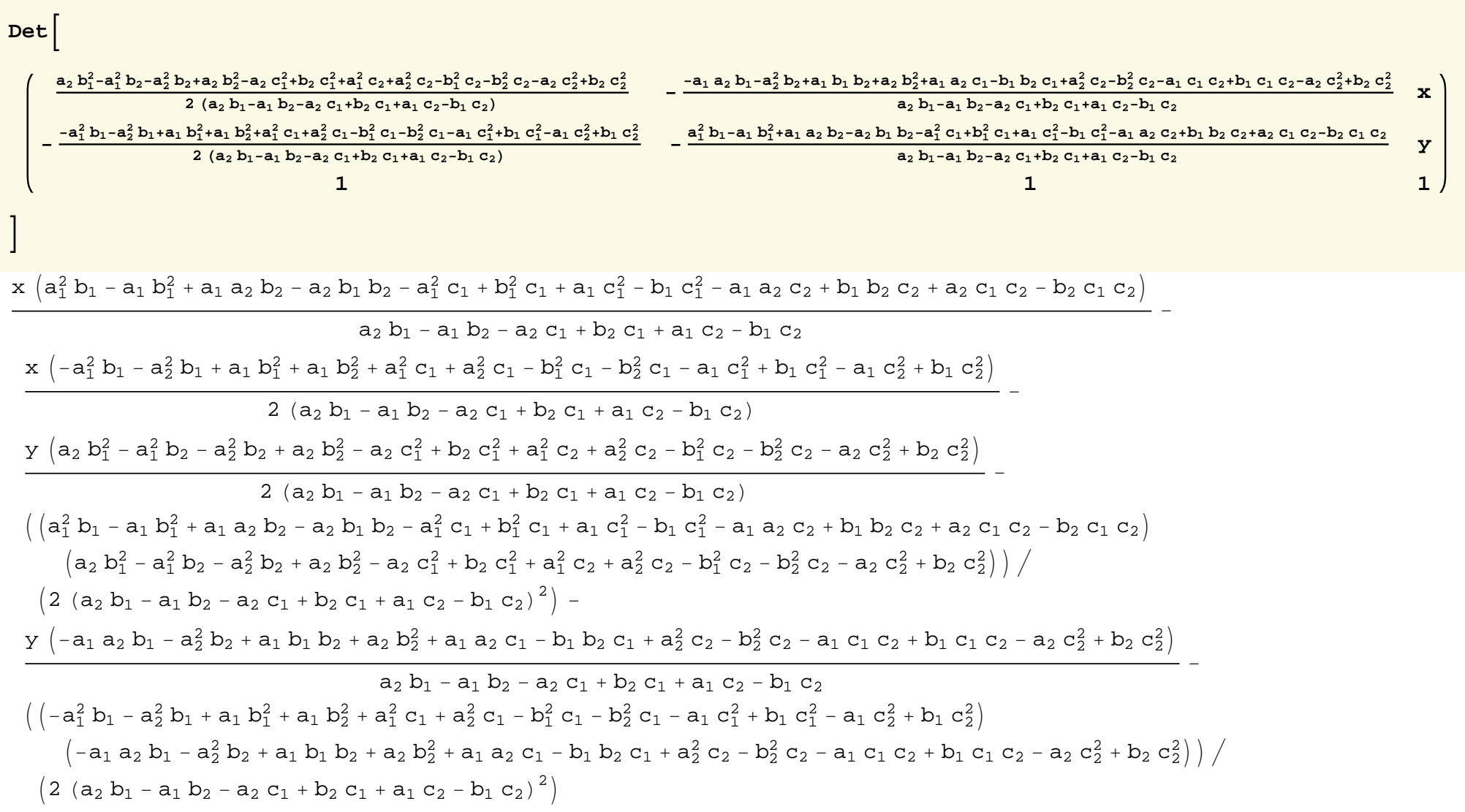


Verify does barycenter T belong to the Euler's line HO, (if it is true, the result must be zero). $\left(\begin{array}{ccc}\mathrm{O}_{1} & \mathrm{~h}_{1} & \mathrm{t}_{1} \\ \mathrm{O}_{2} & \mathrm{~h}_{2} & t_{2} \\ 1 & 1 & 1\end{array}\right)=0$

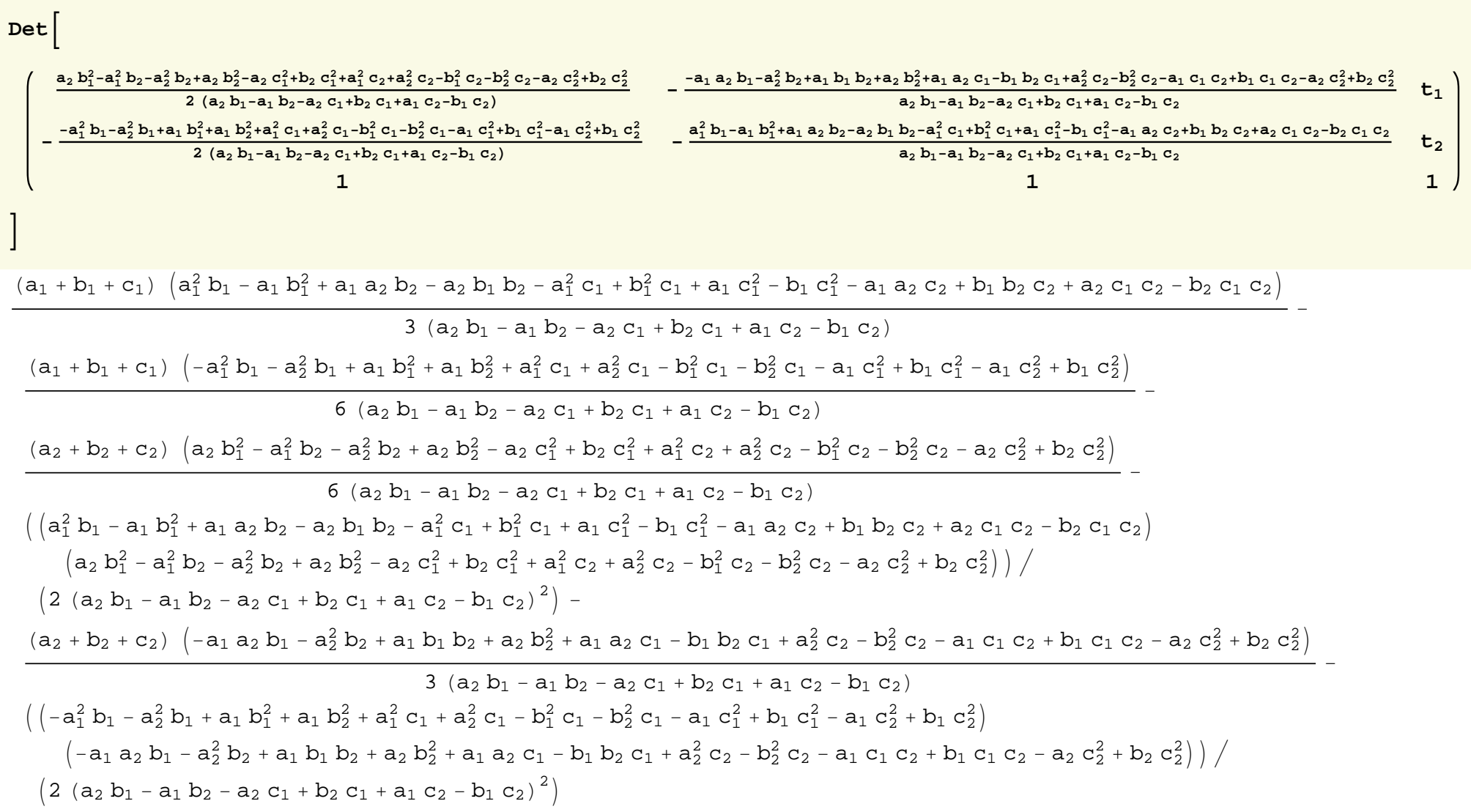

]

$\frac{\left(a_{1}+b_{1}+c_{1}\right)\left(a_{1}^{2} b_{1}-a_{1} b_{1}^{2}+a_{1} a_{2} b_{2}-a_{2} b_{1} b_{2}-a_{1}^{2} c_{1}+b_{1}^{2} c_{1}+a_{1} c_{1}^{2}-b_{1} c_{1}^{2}-a_{1} a_{2} c_{2}+b_{1} b_{2} c_{2}+a_{2} c_{1} c_{2}-b_{2} c_{1} c_{2}\right)}{3\left(a_{2} b_{1}-a_{1} b_{2}-a_{2} c_{1}+b_{2} c_{1}+a_{1} c_{2}-b_{1} c_{2}\right)}-$

$\frac{\left(a_{1}+b_{1}+c_{1}\right)\left(-a_{1}^{2} b_{1}-a_{2}^{2} b_{1}+a_{1} b_{1}^{2}+a_{1} b_{2}^{2}+a_{1}^{2} c_{1}+a_{2}^{2} c_{1}-b_{1}^{2} c_{1}-b_{2}^{2} c_{1}-a_{1} c_{1}^{2}+b_{1} c_{1}^{2}-a_{1} c_{2}^{2}+b_{1} c_{2}^{2}\right)}{6\left(a_{2} b_{1}-a_{1} b_{2}-a_{2} c_{1}+b_{2} c_{1}+a_{1} c_{2}-b_{1} c_{2}\right)}-$

$\left(a_{2}+b_{2}+c_{2}\right)\left(a_{2} b_{1}^{2}-a_{1}^{2} b_{2}-a_{2}^{2} b_{2}+a_{2} b_{2}^{2}-a_{2} c_{1}^{2}+b_{2} c_{1}^{2}+a_{1}^{2} c_{2}+a_{2}^{2} c_{2}-b_{1}^{2} c_{2}-b_{2}^{2} c_{2}-a_{2} c_{2}^{2}+b_{2} c_{2}^{2}\right)$

$6\left(a_{2} b_{1}-a_{1} b_{2}-a_{2} c_{1}+b_{2} c_{1}+a_{1} c_{2}-b_{1} c_{2}\right)$

$\left(\left(a_{1}^{2} b_{1}-a_{1} b_{1}^{2}+a_{1} a_{2} b_{2}-a_{2} b_{1} b_{2}-a_{1}^{2} c_{1}+b_{1}^{2} c_{1}+a_{1} c_{1}^{2}-b_{1} c_{1}^{2}-a_{1} a_{2} c_{2}+b_{1} b_{2} c_{2}+a_{2} c_{1} c_{2}-b_{2} c_{1} c_{2}\right)\right.$

$\left.\left(a_{2} b_{1}^{2}-a_{1}^{2} b_{2}-a_{2}^{2} b_{2}+a_{2} b_{2}^{2}-a_{2} c_{1}^{2}+b_{2} c_{1}^{2}+a_{1}^{2} c_{2}+a_{2}^{2} c_{2}-b_{1}^{2} c_{2}-b_{2}^{2} c_{2}-a_{2} c_{2}^{2}+b_{2} c_{2}^{2}\right)\right) /$

$\left(2\left(a_{2} b_{1}-a_{1} b_{2}-a_{2} c_{1}+b_{2} c_{1}+a_{1} c_{2}-b_{1} c_{2}\right)^{2}\right)-$

$\left(a_{2}+b_{2}+c_{2}\right)\left(-a_{1} a_{2} b_{1}-a_{2}^{2} b_{2}+a_{1} b_{1} b_{2}+a_{2} b_{2}^{2}+a_{1} a_{2} c_{1}-b_{1} b_{2} c_{1}+a_{2}^{2} c_{2}-b_{2}^{2} c_{2}-a_{1} c_{1} c_{2}+b_{1} c_{1} c_{2}-a_{2} c_{2}^{2}+b_{2} c_{2}^{2}\right)$ $3\left(a_{2} b_{1}-a_{1} b_{2}-a_{2} c_{1}+b_{2} c_{1}+a_{1} c_{2}-b_{1} c_{2}\right)$

$\left(\left(-a_{1}^{2} b_{1}-a_{2}^{2} b_{1}+a_{1} b_{1}^{2}+a_{1} b_{2}^{2}+a_{1}^{2} c_{1}+a_{2}^{2} c_{1}-b_{1}^{2} c_{1}-b_{2}^{2} c_{1}-a_{1} c_{1}^{2}+b_{1} c_{1}^{2}-a_{1} c_{2}^{2}+b_{1} c_{2}^{2}\right)\right.$

$\left.\left(-a_{1} a_{2} b_{1}-a_{2}^{2} b_{2}+a_{1} b_{1} b_{2}+a_{2} b_{2}^{2}+a_{1} a_{2} c_{1}-b_{1} b_{2} c_{1}+a_{2}^{2} c_{2}-b_{2}^{2} c_{2}-a_{1} c_{1} c_{2}+b_{1} c_{1} c_{2}-a_{2} c_{2}^{2}+b_{2} c_{2}^{2}\right)\right) /$

$\left(2\left(a_{2} b_{1}-a_{1} b_{2}-a_{2} c_{1}+b_{2} c_{1}+a_{1} c_{2}-b_{1} c_{2}\right)^{2}\right)$

\section{Simplify $[\%]$}

0

- The coordinates of vectors $\overrightarrow{\mathrm{HT}}$ and $\overrightarrow{\mathrm{TO}}$

Vector between the orthocenter $\mathrm{H}$ and barycenter $\mathrm{T}$ is given with difference of their position vectors 


$$
\begin{aligned}
& \mathbf{H T}=\left(\begin{array}{l}
\mathbf{t}_{\mathbf{1}} \\
\mathbf{t}_{\mathbf{2}}
\end{array}\right)-\left(\begin{array}{l}
\mathbf{h}_{\mathbf{1}} \\
\mathbf{h}_{\mathbf{2}}
\end{array}\right) \\
& \left\{\left\{\frac{1}{3}\left(\mathrm{a}_{1}+\mathrm{b}_{1}+c_{1}\right)+\frac{-a_{1} a_{2} b_{1}-a_{2}^{2} b_{2}+a_{1} b_{1} b_{2}+a_{2} b_{2}^{2}+a_{1} a_{2} c_{1}-b_{1} b_{2} c_{1}+a_{2}^{2} c_{2}-b_{2}^{2} c_{2}-a_{1} c_{1} c_{2}+b_{1} c_{1} c_{2}-a_{2} c_{2}^{2}+b_{2} c_{2}^{2}}{a_{2} b_{1}-a_{1} b_{2}-a_{2} c_{1}+b_{2} c_{1}+a_{1} c_{2}-b_{1} c_{2}},\right.\right. \\
& \left.\left\{\frac{1}{3}\left(a_{2}+b_{2}+c_{2}\right)+\frac{a_{1}^{2} b_{1}-a_{1} b_{1}^{2}+a_{1} a_{2} b_{2}-a_{2} b_{1} b_{2}-a_{1}^{2} c_{1}+b_{1}^{2} c_{1}+a_{1} c_{1}^{2}-b_{1} c_{1}^{2}-a_{1} a_{2} c_{2}+b_{1} b_{2} c_{2}+a_{2} c_{1} c_{2}-b_{2} c_{1} c_{2}}{a_{2} b_{1}-a_{1} b_{2}-a_{2} c_{1}+b_{2} c_{1}+a_{1} c_{2}-b_{1} c_{2}}\right\}\right\}
\end{aligned}
$$

Vector between the circumcenter $\mathrm{O}$ and barycenter $\mathrm{T}$ is given with difference of their position vectors

$$
\begin{aligned}
& \text { TO }=\left(\begin{array}{l}
o_{1} \\
o_{2}
\end{array}\right)-\left(\begin{array}{l}
t_{1} \\
t_{2}
\end{array}\right) \\
& \left\{\left\{\frac{1}{3}\left(-a_{1}-b_{1}-c_{1}\right)+\frac{a_{2} b_{1}^{2}-a_{1}^{2} b_{2}-a_{2}^{2} b_{2}+a_{2} b_{2}^{2}-a_{2} c_{1}^{2}+b_{2} c_{1}^{2}+a_{1}^{2} c_{2}+a_{2}^{2} c_{2}-b_{1}^{2} c_{2}-b_{2}^{2} c_{2}-a_{2} c_{2}^{2}+b_{2} c_{2}^{2}}{2\left(a_{2} b_{1}-a_{1} b_{2}-a_{2} c_{1}+b_{2} c_{1}+a_{1} c_{2}-b_{1} c_{2}\right)}\right\},\right. \\
& \left.\left\{\frac{1}{3}\left(-a_{2}-b_{2}-c_{2}\right)-\frac{-a_{1}^{2} b_{1}-a_{2}^{2} b_{1}+a_{1} b_{1}^{2}+a_{1} b_{2}^{2}+a_{1}^{2} c_{1}+a_{2}^{2} c_{1}-b_{1}^{2} c_{1}-b_{2}^{2} c_{1}-a_{1} c_{1}^{2}+b_{1} c_{1}^{2}-a_{1} c_{2}^{2}+b_{1} c_{2}^{2}}{2\left(a_{2} b_{1}-a_{1} b_{2}-a_{2} c_{1}+b_{2} c_{1}+a_{1} c_{2}-b_{1} c_{2}\right)}\right\}\right\}
\end{aligned}
$$

- Checking the ratio of vectors $\overrightarrow{\mathrm{HT}}$ and $\overrightarrow{\mathrm{TO}}$

HT / TO

$$
\begin{aligned}
& \left\{\left\{\frac{\frac{1}{3}\left(a_{1}+b_{1}+c_{1}\right)+\frac{-a_{1} a_{2} b_{1}-a_{2}^{2} b_{2}+a_{1} b_{1} b_{2}+a_{2} b_{2}^{2}+a_{1} a_{2} c_{1}-b_{1} b_{2} c_{1}+a_{2}^{2} c_{2}-b_{2}^{2} c_{2}-a_{1} c_{1} c_{2}+b_{1} c_{1} c_{2}-a_{2} c_{2}^{2}+b_{2} c_{2}^{2}}{a_{2} b_{1}-a_{1} b_{2}-a_{2} c_{1}+b_{2} c_{1}+a_{1} c_{2}-b_{1} c_{2}}}{\frac{1}{3}\left(-a_{1}-b_{1}-c_{1}\right)+\frac{a_{2} b_{1}^{2}-a_{1}^{2} b_{2}-a_{2}^{2} b_{2}+a_{2} b_{2}^{2}-a_{2} c_{1}^{2}+b_{2} c_{1}^{2}+a_{1}^{2} c_{2}+a_{2}^{2} c_{2}-b_{1}^{2} c_{2}-b_{2}^{2} c_{2}-a_{2} c_{2}^{2}+b_{2} c_{2}^{2}}{2}}\right\}\right. \\
& 2\left(a_{2} b_{1}-a_{1} b_{2}-a_{2} c_{1}+b_{2} c_{1}+a_{1} c_{2}-b_{1} c_{2}\right) \\
& \left.\left\{\frac{\frac{1}{3}\left(a_{2}+b_{2}+c_{2}\right)+\frac{a_{1}^{2} b_{1}-a_{1} b_{1}^{2}+a_{1} a_{2} b_{2}-a_{2} b_{1} b_{2}-a_{1}^{2} c_{1}+b_{1}^{2} c_{1}+a_{1} c_{1}^{2}-b_{1} c_{1}^{2}-a_{1} a_{2} c_{2}+b_{1} b_{2} c_{2}+a_{2} c_{1} c_{2}-b_{2} c_{1} c_{2}}{a_{2} b_{1}-a_{1} b_{2}-a_{2} c_{1}+b_{2} c_{1}+a_{1} c_{2}-b_{1} c_{2}}}{\frac{1}{3}\left(-a_{2}-b_{2}-c_{2}\right)-\frac{-a_{1}^{2} b_{1}-a_{2}^{2} b_{1}+a_{1} b_{1}^{2}+a_{1} b_{2}^{2}+a_{1}^{2} c_{1}+a_{2}^{2} c_{1}-b_{1}^{2} c_{1}-b_{2}^{2} c_{1}-a_{1} c_{1}^{2}+b_{1} c_{1}^{2}-a_{1} c_{2}^{2}+b_{1} c_{2}^{2}}{2\left(a_{2} b_{1}-a_{1} b_{2}-a_{2} c_{1}+b_{2} c_{1}+a_{1} c_{2}-b_{1} c_{2}\right)}}\right\}\right\}
\end{aligned}
$$

\section{Simplify $[\%]$}

$\{\{2\},\{2\}\}$ 


\section{References}

[1] Ambrus András: Bevezetés a matematikadidaktikába, ELTE Eötvös kiadó, Budapest, 1995

[2] Balka, D. S. (1974): Creative ability in mathematics. Arithmetic Teacher, 21, 633-636.

[3] Anton Bilimović: A polonijevi problemi, www.matf.bg.ac.yu, (2007-03-21)

[4] Johanne Bolyai: Scientiam Spatii, Polygon, Szeged, 2002

[5] Cofman, Judita: What to Solve? -Problems and Suggestions for Young Mathematicians, Clarenden Press, Oxford, 1994

[6] Cofman, Judita: Numbers and Shapes Revisited-More problems and Suggestions for Young Mathematicians, Clarenden Press, Oxford, 1995

[7] H.S.M. Coxeter: A geometriák alapjai, Müszaki Könyvkiadó, Budapest, 1987, ISBN 9631068439

[8] H.S.M. Coxeter: Projektív geometria, Gondolat, Budapest, 1986, ISBN 963281 6781

[9] Euclid, Elements, Gondolat, Budapest, 1983

[10] Hajós György: Bevezetés a geometriába, Tankönyvkiadó, Budapest, 1984

[11] David Hilbert: Grundlagen der Geometrie, Osnovi geometrije, Matematicki Institut, Beograd, 1957

[12] Jovan D. Kečkić: Matematika za treći razred gimnazije, Naučna knjiga, Beograd, 1990

[13] Lénárt István, Nem-euklideszi kalandok, Key Curriculum Press , 2009

[14] Rosa Massa, Ftima Romero, Iolanda Guevara: Teaching mathematics through history: Some trigonometric concepts, The Global and the Local: The History of Science and the Cultural Integration of Europe. Proceedings of the 2nd ICESHS (Cracow, Poland, September 69, 2006)

[15] Eric Louis Mann: Mathematical Creativity and School Mathematics: Indicators of Mathematical Creativity in Middle School Students, Ph.D. dissertation, University of Connecticut, 2005

[16] Milan Mitrović, Srdjan Ognjanović, Mihailo Veljković, Ljubinka Petković, Nenad Lazarević: Geometrija I za matematičke gimnazije, Krug Beograd, 2003

[17] Munkácsy Katalin: A matematikai bizonyításfogalom változásának hatása a tanításra, http://tandem.lauder.hu/ujsag/cikkek/20000209.html 
[18] Presnky Marc: Digital Natives, Digital Immigrants, On the Horizon, MCB University Press, Vol. 9 No. 5, October 2001

[19] Pólya György: A gondolkodás iskolája, Bibliotheca Kiadó, Budapest, 1957

[20] Pólya György: Mathematical Discovery on understanding, learning and teaching problem solving, John Wiley and Sons Inc., New York, 1962

[21] Ripco Sipos Elvira: Teaching geometry using computer visualization, Teaching Mathematics and Computer Science, TMCS 7 (2009)2, ISSN 1589-7389

[22] Ripco Sipos Elvira: Apollonius' problems in grammar school, Teaching Mathematics and Computer Science, TMCS 7 (2009)1, ISSN 1589-7389

[23] Ripco Sipos Elvira: Matematika érettségi vizsgák a zentai "Bolyai" gimnáziumban, 169-177, Kutató Tanárok Tudományos Közleményei, 2007-2008, ISBN 9638722517

[24] Alan H. Schoenfeld: Mathematical Problem Solving, Academic Press, INC., New York, 1985

[25] Alan H. Schoenfeld: Mathematical Thinking and Problem Solving, Lawernce Erlbaum Associates, Publishers, Hillsdale, New Jersey, 1994

[26] Richard R. Skemp: The Psychology of Learning Mathematics, Lawrence Erlbaum Associates, New Jersey, U.S.A, Hungarian Translation (C1975 Klein Sándor, pages: $42-44,138,152$

[27] Szilasi Lajos: http://www.jgytf.u-szeged.hu/tanszek/matematika/Bolyai/index.html, 05.06.2009

[28] Patrick Suppes: The Aims of Education, from Suppes, P. (1968). Can there be a normative philosophy of education? In G.L. Newsome, Jr. (Ed.), Philosophy of Education. Studies in Philosophy and Education series, Proceedings of the 24th annual meeting of the Philosophy of Education Society-Santa Monica, April 7-10, 1968, Edwardsville, IL: Southern Illinois University, 1-12. Reprinted in J.P. Strain (Ed.), Modern Philosophies of Education. New York: Random House, 1971, 277288.

[29] David Tall: The Cognitive Development of Proof: Is Mathematical proof For All or For Some?, Conference of the University of Chicago Scholl Mathematics Project, August 1998

[30] David Tall: Computers and the Link Between Intuition and Formalism, Published in Proceedings of the Annual International Conference on technoogy in Collegiate Mathematics, Addson-Wesley Longman., pp.417-421

[31] David Tall: Advanced Mathematical Thinking and The Computer,Published in Proceedings of the 20th University Mathematics Teaching Conference, Shell Centre, Nottingham, pp. 1-8 (1996)

[32] David Tall: The Psychology of Advanced Mathematical Thinking: Biological Brain and Mathematical Mind, Conference of the International group for the Psychology of Mathematics Education, Lisbon, July 1994 
[33] David Tall: Interrelationships between mind and computer: pro- cesses, images symbols, Advanced Technologies in the Teaching of Math- ematics and Science, New York: Springer-Verlag, 385-413, 1993

[34] David Tall: Enviroments for enactive and visual manipulation, The Psychology of Advanced Mathematical Thinking: Biological Brain and Math- ematical Mind, Conference of the International Group for the Psychology of Mathematical Education, Lisbon, July, 1994

\section{Internetes oldalak}

[35] www.en.wikipedia.org, History of General Relativity, (07.10.2008)

[36] Internet:Math World,Wolfram Research, http://www.mathworld.wolfram.com, (2007-03-21)

[37] Wolfram Mathematica homepage, http://demonstrations.wolfram.com/PtolemysTheorem/, (25.03.2010)

[38] http://www-history.mcs.st-andrews.ac.uk/Biographies, (02.03.2011) 


\section{Publications and Conferences}

List of publications:

1. Ripco Sipos Elvira: Apollóniosz problémái - tanítás, szerkesztés, vizualizáció, ÚJ KÉP, XI évfolyam, 4-5 szám, 2007 április-május, 63-74, ISSN 1450-5010

2. Ripco Sipos Elvira: A geometria tanátása számitógép segétségével, ÚJ KÉP, XI évfolyam, 1-2 szám, 2007 január-február, 51-60, ISSN 1450-5010

3. Ripco Sipos Elvira: Euklides - a geometriai szerkesztöprogram, ÚJ KÉP, IX évfolyam, 1-2 szám, 2005 január-február, 30-33, ISSN1450-5010

4. Ripco Sipos Elvira: Hogyan alkalmazom a szmítógépet a matematikaórán (geometriaórán)?, ÚJ KÉP, XI. évfolyam, 2007 október-november, 19-35, ISSN $1450-5010$

5. Ripco Sipos Elvira: Geometria tanítása a zentai Bolyaiban, ÚJ KÉP, XII. évfolyam, 2008 október-november, 32-36, ISSN 1450-5010

6. Ripco Sipos Elvira: Apollóniosz problémái, TAVASZI SZÉL Konferenciakiadvány, 2007, 284-289, ISBN 978-963-87569-1-6

7. Ripco Sipos Elvira: Problémamegoldás és tehetségfejlesztés a számitógép segítségével a geometriaórán, A TEHETSÉGEK SZOLGÁLATÁBAN I. NEMZETKÖZI TEHETSÉGGONDOZÓ KONFERENCIA, Magyarkanizsa, 2009. március 23, Konferenciakiadvány, 83-88, ISBN 978-86-84699-42-0

8. Ripco Sipos Elvira: Teaching geometry using computer visualizations, TEACHING MATHEMATICS AND COMPUTER SCIENCE, (2009), 1-19, ISSN 1589-7389

9. Ripco Sipos Elvira: Apollonius' problems in grammar school, TEACHING MATHEMATICS AND COMPUTER SCIENCE, (2009), 7/1, 69-85, ISSN 15897389

10. Ripco Sipos Elvira: A geometria tanításának útjai, MAGYAR SZÓ, ÜVEGGOLYÓ, 2010. március 1-8

11. Ripco Sipos Elvira: Alkalmazzuk a számítógépet a geometriaórán!, A MATEMATIKA TANÍTÁSA, MÓDSZERTANI FOLYÓIRAT, XVIII évfolyam, 2 szám, 2010, MOZAIK Kiadó Kft, Szeged, ISSN 1216-6650

12. Ripco Sipos Elvira: Matematika érettségi vizsgák a zentai "Bolyai" gimnáziumban, 169-177, KUTATÓ TANÁROK TUDOMÁNYOS KÖZLEMÉNYEI, 2007-2008, ISBN 9638722517 
13. Ripco Sipos Elvira: Tehetséggondozás a zentai Bolyaiban, 340-347, KUTATÓ TANÁROK TUDOMÁNYOS KÖZLEMÉNYEI, 2007-2008, ISBN 96387225 17

14. Ripco Sipos Elvira: Tehetségfejlesztés a számítógép segítségével, A MATEMATIKA TANÍTÁSA, MÓDSZERTANI FOLYÓIRAT, XVIII évfolyam, 3 szám, 2010, MOZAIK Kiadó Kft, Szeged, ISSN 1216-6650

15. Ripco Sipos Elvira: Hyperbolic geometry and tiling, ISIS-Symmetry congressfestival, 342-345, Gmuend, ISSN 1447-607X

\section{Konferenciákon tartott előadások}

1. Miskolc: History of Mathematics and Teaching of Mathematics, 2006 május 19-21, "Teaching Geometry using Computers"

2. Karcag: Kutató Tanárok I konferenciája, 2006 október 6-7, “A geometria tanítása számítógép segítségével"

3. Budapest: DOSz konferencia, 2007 május 18-21, "Apollóniosz problémái- tanítás, szerkesztés, vizualizáció"

4. Szabadkai Nyári Akadémia, 2007 augusztus 6-10, "Hogyan alkalmazom a számítógépet a matematikaórákon?"

5. Novi Sad: Medunarodna Konferencija za Nastavu Matematike, 2007 augusztus 2223, "Problemsko rešavanje zadataka iz geometrije pomoću računara"

6. Győr: Kutató Tanárok II konferenciája, 2007. október 12-13, "Matematikai érettségi vizsgák a zentai Bolyaiban"

7. Budapest: Varga Tamás Módszertani napok, 2007. november 9-10, "Hogyan alkalmazom a számítógépet a geometriaórákon?"

8. Zenta: T-day, 2008. április 4-5, "Nastava geometrije u gimnaziji Bolyai"

9. Novi Sad: XII Kongres Matematičara Srbije, 2008. augusztus 28-szeptember 2, "Apolonijevi problemi/ nastava u srednjoj školi Boljai"

10. Budapest: Varga Tamás Módszertani Napok, 2008. november 7-8, "Geometrical Transformations Using Computer"

11. Győr: Kutató Tanárok III konferenciája, 2008. október 10-11, "Tehetséggondozás a zentai Bolyaiban"

12. Magyarkanizsa: III Tehetség Nap, 2009. március 23, "Problémamegoldás és tehetségfejlesztés a számítógép segítségével a geometriaórán"

13. Szeged: History of Mathematics and Teaching of Mathematics, 2010. május 20-23, "Important Theorems in geometry"

14. Szeged: Szakmódszertani kutatások a természettudományos, illetve a matematika és az informatika tantárgyhoz kapcsolódóan, 2010. május 20-21, "A geometriák alapjai" 
15. Gmuend: ISIS-Symmetry:Art and Science 8th Interdisciplinary Study of Symmetry congress-festival, 2010. augusztus 23-28, "Hyperbolic geometry and tiling, learn and teach using computer"

16. Zenta: I. Vajdasági Tehetségpont Konferencia, 2010. október 1-2, "Nevezetes tételek a GeoGebrában"

17. Budapest: Varga Tamás Módszertani napok, 2010. november 6

18. Novi Sad: GeoGebra Conference for Southeast Europe 2011, január 15,16, "Izometrijske transformacije u GeoGebra DGS" 